\author{
Universidade de São Paulo \\ Faculdade de Filosofia, Letras e Ciências Humanas \\ Departamento de Letras Modernas \\ Programa de Pós-Graduação em Língua e Literatura Francesa
}

\title{
Les soleils des Indépendances: da sociedade sólida ao prelúdio dos laços efêmeros
}

\author{
Maria Suzana Moreira do Carmo
}




\author{
Universidade de São Paulo \\ Faculdade de Filosofia, Letras e Ciências Humanas \\ Departamento de Letras Modernas \\ Programa de Pós-Graduação em Língua e Literatura Francesa
}

\title{
Les soleils des Indépendances: da sociedade sólida ao prelúdio dos laços efêmeros
}

\section{Maria Suzana Moreira do Carmo}

Tese apresentada ao Programa de PósGraduação em Língua e Literatura Francesa do Departamento de Letras Modernas da Faculdade de Filosofia, Letras e Ciências Humanas da Universidade de São Paulo, para obtenção do título de Doutor em Letras.

Orientadora: Profa. Dra. Maria Cecília Queiroz de Moraes Pinto

\section{São Paulo}

$$
\text { - } 2007 \text { - }
$$




\section{FOLHA DE APROVAÇÃO}

\section{Maria Suzana Moreira do Carmo}

"Les soleils des Indépendances:

da sociedade sólida ao prelúdio dos laços efêmeros"

Tese apresentada ao Programa de PósGraduação em Língua e Literatura Francesa do Departamento de Letras Modernas da Faculdade de Filosofia, Letras e Ciências Humanas da Universidade de São Paulo, para obtenção do título de Doutor em Letras.

Área de concentração: Lingüística, Letras e Artes.

Aprovada em:

\section{Banca Examinadora}

$\operatorname{Prof}(a) . \operatorname{Dr}(a)$.

Instituição: Assinatura:

$\operatorname{Prof}(a) . \operatorname{Dr}(a)$.

Instituição: Assinatura:

$\operatorname{Prof}(a) . \operatorname{Dr}(a)$.

Instituição: Assinatura:

Prof(a). Dr(a).

Instituição: Assinatura:

Prof(a). Dr(a).

Instituição: Assinatura: 
A Diva Moreira do Carmo

In memoriam

Com amor, carinho e enorme gratidão. Sempre! 


\section{Agradecimentos}

Laços sólidos e duradouros, laços breves e efêmeros... na bagagem, carregamos sempre a memória da gratidão... Assim, em nome dos inúmeros débitos, agradeço em primeiro lugar à minha irmã Maria Angélica Vergara Wasserman, pelo apoio de todas as horas e pelas críticas amorosas e argutas; ao meu cunhado Júlio César de Faria Alvim Wasserman, pela contribuição acadêmica, paciência e pela amizade sem falhas; ao Gabriel e à Luisa, pelo carinho e tolerância nas horas fortes.

Agradeço em seguida aos outros laços da vida: a Lia Vera Tomás, amiga sempre presente nos momentos próprios e impróprios do destino; a Maria da Paixão Mota, pelos cuidados e respeito às solitárias horas de estudo e pesquisa; aos amigos Luciano Loprete, Célia Mello e Danielle Blanchard, que trouxeram outros ares nos momentos de dúvida; a Dakouri Gadou, Aghi Bahi e Kouadio Affian, verdadeiros companheiros durante a pesquisa e as restrições de ordem política em Abidjan, na Costa do Marfim; a Larissa Dogbo e Fanta Kouye, amigas que me abriram muitas portas na Universidade de Abidjan/Cocody; a Maria José dos Santos, pelo apoio e solidariedade sob o sol de Abidjan.

Agradeço ainda a todos os membros do GERLIF (Groupe d'Etudes et de Recherches sur la Littérature Francophone), da Universidade de Abidjan/Cocody, pelas trocas durante os seminários de pesquisa; aos funcionários da biblioteca do CERAP (Centre de recherches et d'action pour la paix); a Sébastien Roy, representante do Serviço de Cooperação e Ação Cultural do Consulado Geral da França em São Paulo, pelos incentivos recebidos; a Prof $^{a}$ Dr $^{a}$ Alexandra Serpa Geraldini, Diretora da Faculdade de Comunicação e Filosofia da PUC-SP, pelo apoio e amizade; aos demais colegas e alunos que deixaram boas recordações do período passado na PUC-SP.

Agradeço igualmente os apoios financeiros recebidos: a Bolsa de Estudos concedida pela AUF (Agence Universitaire de la Francophonie) e 
AFELSCH (Association des Facultés ou Établissements de Lettres et Sciences Humaines des Universités d'expression française), destinada aos Departamentos de Francês do Ensino Superior (DEF); e a Bolsa Parcial de Capacitação Docente da Pontifícia Universidade Católica de São Paulo, concedida pelo Departamento de Francês, no período de agosto a dezembro de 2006.

A acolhida e co-orientação do Prof. Dr. Gérard Dago Lézou e a inestimável contribuição da $\operatorname{Prof}^{\mathrm{a}} \mathrm{Dr}^{\mathrm{a}}$ Virginie Kouassi, da Universidade de Abidjan/Cocody.

Agradeço, sobretudo, a Prof ${ }^{a}$ Dr $^{a}$ Maria Cecília Queiroz de Moraes Pinto, pela orientação e constante delicadeza em seu discurso: fonte de inspiração para a minha vida profissional. 


\section{Resumo}

CARMO, M. S. M. Les soleils des Indépendances: da sociedade sólida ao prelúdio dos laços efêmeros. 2007. 216 f. Tese (Doutorado). Programa de Pós-Graduação em Língua e Literatura Francesa, Departamento de Letras Modernas, Faculdade de Filosofia, Letras e Ciências Humanas, Universidade de São Paulo, São Paulo, 2007.

O romance Les soleils des Indépendances, de Ahmadou Kourouma suscitou inúmeros estudos críticos desde sua publicação, em 1968, pelas Presses Universitaires du Canada. A despeito da orientação temática ou ideológica dos autores, o romance africano reflete, freqüentemente, os conflitos gerados pela imposição da cultura européia. Os estudos relativos à primeira incursão de Kourouma na literatura apontam, em geral, a introdução de estruturas lógicocognitivas do pensamento malinké na língua francesa como a efetiva inovação do autor, marcando assim, uma nova orientação na literatura africana. Propondo uma outra via de interpretação à tendência crítica de reforçar os conflitos entre as culturas africana e ocidental, a presente pesquisa tem por objetivo analisar os aspectos estéticos e temáticos do romance a fim de mostrar como a passagem da tradição à modernidade leva o indivíduo à reorganização de sua identidade. As análises mostraram que, em contraposição à dificuldade de Fama, personagem principal, em negociar suas pertenças culturais, sua primeira esposa, Salimata, torna-se uma matriz da transculturação, integrando em sua vida quotidiana elementos da modernidade sem, contudo, renunciar ao ideal feminino tradicional. Além dessa composição, Papillon, em sua rápida e leve participação na trama, encarna, de maneira subliminar, um traço atribuído por Zygmunt Bauman à modernidade tardia, ou seja, a fluidez dos laços sociais e afetivos dos contatos breves.

Palavras-chave: Ahmadou Kourouma; tradição oral; modernidade; identidade; transculturação. 


\section{Abstract}

CARMO, M. S. M. Les soleils des Indépendances: from solid society to the prelude of ephemeral bonds. 2007. $216 \mathrm{f}$. Thesis (Doctorate). Programa de Pós-Graduação em Língua e Literatura Francesa, Departamento de Letras Modernas, Faculdade de Filosofia, Letras e Ciências Humanas, Universidade de São Paulo, São Paulo, 2007.

The novel Les soleils des Indépendances, written by Ahmadou Kourouma engendered a number of criticism studies since its publication in 1968 by the Presses Universitaires du Canada. In spite of the authors's thematic or ideological orientation, the African novel frequently reveals the conflicts generated by the imposed European culture. Most of the studies concerning the first published work of Kourouma underline the introduction of logicalcognitive structures of the Malinké thinking within the French language, representing an effective innovation from this author that marked a new orientation of the African literature. Proposing a new analysis for "Les soleils des Indépendances" to the criticism tendency that reinforce the conflicts between the African and Occidental cultures, the present research, evaluated the aesthetic and thematic aspects, showing how the route from tradition to modernity, takes the individual to re-organize its identity. This work also showed that, in contrast with the difficulty of Fama, main character of the novel, to trade his cultural identification, his first wife, Salimata, becomes a matrix of transculturation, by integrating elements of modernity in her life, without renouncing, however, to the traditional feminine ideals. Besides this composition, Papillon, in his fast and shallow participation at the novel, incarnates, in a subliminal manner, an aspect attributed by Zygmunt Bauman to the post-modernity, i.e., the fluidity of the social and affective bonds, characteristics from the ephemeral relationships.

Key words: Ahmadou Kourouma; oral tradition; modernity; identity; transculturation. 


\section{Résumé}

CARMO, M. S. M. Les soleils des Indépendances: de la société solide au prélude des liens éphémères. 2007. 216 f. Thèse (Doctorat). Programa de Pós-Graduação em Língua e Literatura Francesa, Departamento de Letras Modernas, Faculdade de Filosofia, Letras e Ciências Humanas, Universidade de São Paulo, São Paulo, 2007.

Le roman Les soleils des Indépendances, d'Ahmadou Kourouma a suscité de nombreuses études critiques depuis sa publication, em 1968, par les Presses Universitaires du Canada. En dépit de I'orientation thématique ou idéologique des auteurs, le roman africain reflète souvent les conflits engendrés par l'imposition de la culture européenne. Les études concernant la première incursion de Kourouma dans le domaine de la littérature montrent, en général, l'introduction de structures logico-cognitives de la pensée malinké dans la langue française comme une innovation effective de la littérature africaine. Dans le but de proposer une nouvelle voie interprétative à la tendance critique de renforcer les conflits existant entre les cultures africaine et occidentale, cette recherche évalue les aspects esthétique et thématique du roman afin de montrer comment le passage de la tradition à la modernité impose à l'individu une réorganisation de son identité. Les analyses nous ont permis de démontrer que contrairement à la difficulté de Fama de négocier ses appartenances culturelles, Salimata, sa première femme, devient une matrice de la transculturation vécue par les Africains, tout en intégrant dans sa vie quotidienne des éléments de la modernité sans pour autant renoncer à ses idéaux féminins de la tradition. A part cette composition, Papillon, dans sa brève et légère intervention dans l'intrigue, annonce en filigranes un trait attribué par Zygmunt Bauman à la modernité tardive, c'est-à-dire la fluidité des liens sociaux et affectifs.

Mots-clés: Ahmadou Kourouma; tradition orale; modernité; transculturation; identité. 


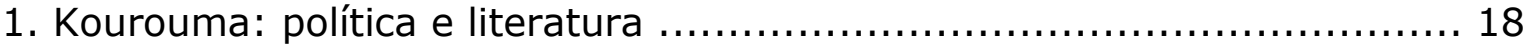

2. Povo e cultura Malinké .......................................................... 34

3. Da cheferia tradicional à administração colonial .............................. 37

4. Les soleils des indépendances: apresentação e resumo ....................... 44

\section{DA NARRATIVA TRADICIONAL AO ROMANCE DAS} INDEPENDÊNCIAS

1. O surgimento da literatura escrita africana de língua francesa .............. 55

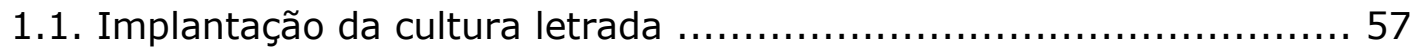

1.2. Mestres do discurso: do griot ao escritor moderno .......................62 62

2. A narrativa tradicional: fonte temática e procedimentos narrativos ........ 72

2.1. Injustiça e espoliação ................................................. 73

2.2. A viagem imaginada e o deslocamento efetivo ...................... 74

2.3. Estética e composição na narrativa heróica ........................... 77

2.4. Do romance histórico ao romance moderno: alterações e exigências da recepção ................................................................. 83

2.5. Função da narrativa: do etos da tradição ao etos da sociedade híbrida 
IV. LES SOLEILS DES INDEPENDANCES: da sociedade sólida ao prelúdio dos laços efêmeros

1. Dinâmica das identidades ................................................. 97

1.1. Identidade nacional e identidade cultural ......................... 102

1.2. Novos sólidos e modernidade líquida ............................... 111

2. Estética da oralidade e ascendência ocidental .............................. 119

2.1. Do griot ao escritor .............................................. 123

2.2. Das unidades autônomas aos fragmentos dependentes .......... 132

2.3. Do herói épico ao príncipe decaído ................................. 135

2.4. Da mulher africana aos costumes ligeiros ......................... 144

3. Do espaço organizado à geografia da exclusão ............................... 161

V. CONCLUSÃO: das preces à aceleração temporal ...................... 180

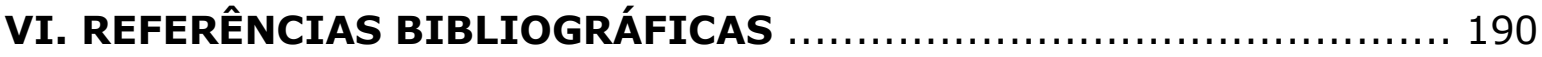

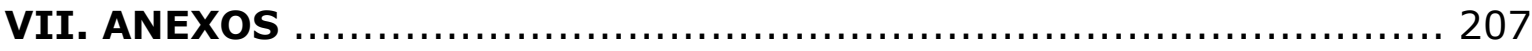

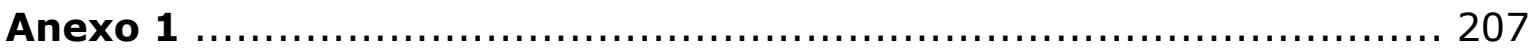

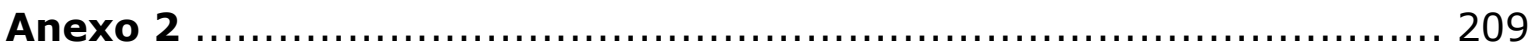

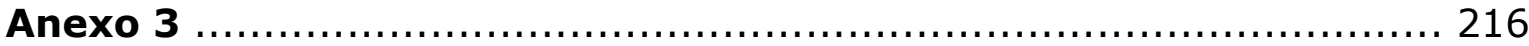




\section{INTRODUÇÃO}

Da sociedade sólida ao prelúdio dos laços efêmeros: o sub-título desta tese condensa, por um lado, o percurso das análises que iremos apresentar mas, por outro, pode provocar certo estranhamento. Tomada de empréstimo da teoria de Zygmunt Bauman a respeito da liquefação da sociedade moderna, a expressão sociedade sólida refere-se a um determinado tipo de organização social e política que permitia ao indivíduo uma identificação, satisfatória e inquestionável, como membro de uma família, de uma religião ou de uma tribo. No processo de constituição das grandes nações européias, um dos focos da teoria baumaniana, a lealdade a sociedades mais tradicionais foi transferida às grandes nações. Tal mudança, por ele classificada como a substituição de um sólido por outro, levou o indivíduo a uma reorganização das pertenças que compunham sua identidade, o que compreendia processos de seleção, assimilação ou rejeição e anunciava, de maneira subliminar, um traço atribuído à modernidade líquida, na qual a noção de tempo se sobrepõe à de espaço e promove a era da fluidez e dos contatos breves. Assim, entendemos que a passagem da sociedade sólida à sociedade líquida não deixa de vislumbrar os trânsitos e é sob essa perspectiva que pretendemos utilizar a teoria baumaniana como um dos recursos de análise do corpus escolhido, ou seja, trata-se, antes, de um recurso metodológico do qual inferimos uma certa similaridade com a transferência das sociedades tradicionais africanas para organização social e política imposta pelos europeus. No nosso caso, a sociedade sólida é entendida como um tipo de identificação confortável para o indivíduo na medida em que não se questiona os princípios que regem essa identificação. Das sociedades sólidas aos laços efêmeros o percurso é, de fato, longo e escapa ao referente histórico do romance Les soleils des Indépendances, mas o recurso ao prelúdio não deixa de assinalar que, em nossa leitura, apontamos a matriz de um desenvolvimento posterior e que, como todo processo evolutivo, começa a se formar como exercício prévio, como os primeiros passos de uma transformação. 
Em Écriture et identité dans la littérature africaine ${ }^{1}$, André-Patient Bokiba analisa as principais questões relacionadas à experiência de criação do escritor africano. Para tanto, o autor parte de uma noção que descreve a literatura africana ${ }^{2}$ como a execução de uma arte que se fundamenta numa tripla dimensão: em primeiro lugar, encontramos, como em toda literatura, o uso criativo da palavra escrita como recurso substancial de criação; em segundo, a presença da língua escrita, que modela o próprio destino dessa literatura como "o produto insólito do encontro e do acasalamento" (BOKIBA, 1998 , p. 9) de culturas e de uma língua que pertencem a espaços distintos. A terceira dimensão inscreve a literatura escrita africana no terreno da história, como efeito de seu contexto de criação. As circunstâncias que propiciaram o nascimento da literatura escrita negro-africana - a introdução da educação formal pelas mãos do colonizador em um continente orientado social e culturalmente pela oralidade - levaram o romancista africano a elaborar suas obras segundo uma visão estética que se apoiava tanto na tradição romanesca européia quanto nas narrativas da literatura tradicional africana. Em que pese o uso do recurso estrangeiro, e a despeito da orientação ideológica do autor, a trajetória das literaturas africanas revela uma produção que sublinha o caráter antagônico das relações entre brancos e negros, refletindo assim a transculturação resultante do encontro da cultura ocidental com a tradição africana. Se a literatura do ocidente modelou, em parte, a criação dos países colonizados, a preservação de elementos da tradição oral tornou-se um meio privilegiado de defesa do direito à diferença e à constituição de campos literários africanos que se demarcam do cânone ocidental. É sob essa perspectiva que faremos as análises do romance que constitui nosso objeto de pesquisa.

1 Os textos teóricos e depoimentos, originalmente em francês, serão por mim traduzidos e terão as transcrições dos originais em notas de rodapé. Quanto aos textos literários, as citações serão mantidas no original, em francês.

${ }^{2}$ A apreensão singular das literaturas africanas é uma concepção do autor. Não apenas Bokiba, mas ainda Makouta-Mboukou, Amadou Koné, entre outros, são autores que não se referem à pluralidade das literaturas africanas. Portanto, a posição por eles adotada no que concerne essa questão não é necessariamente por mim endossada. 
O romance Les soleils des Indépendances, de Ahmadou Kourouma, vem sendo amplamente discutido e ocupa lugar de destaque nas obras dedicadas à história e à crítica das literaturas africanas. Depois de ter sido recusado por várias editoras francesas por não corresponder aos padrões da norma culta da língua francesa, Les soleils des indépendances recebeu o Prix de la francophonie du Québec e foi publicado pela Presses Universitaires du Canada, em 1968. Após o sucesso obtido com a publicação canadense, as Éditions du Seuil, que já haviam rejeitado o manuscrito da obra devido às incorreções da língua francesa, comprariam os direitos de publicação e lançariam a primeira edição francesa em 1970. Segundo Makhily Gassama (1995), foi graças à ausência de preconceitos, de idéias pré-concebidas em suas relações com os seres e os eventos, que a francofonia canadense conseguiu salvar uma das maiores obras da literatura negra de língua francesa ${ }^{3}$. Além da questão temática que envolve o abuso do poder tirânico e a espoliação dos direitos do cidadão, corolário do período colonial, a introdução de estruturas lógicocognitivas da língua malinké na língua francesa mobilizou grande parte da crítica referente ao romance.

Os artigos e trabalhos acadêmicos dedicados à obra revelam quase um consenso em torno da idéia de violação e constrangimento da língua francesa como um ato de inovação do romance africano. Para o autor, a dupla inscrição lingüística foi tão somente o fruto da fidelidade devida à expressão dos personagens de etnia malinké, mas tal procedimento não deixa de se aliar ao projeto político de Kourouma, que encontrou na criação literária um meio de denunciar os abusos cometidos pelo europeu contra o povo africano. Seu primeiro romance visa não apenas apontar os males causados pela colonização no continente africano, mas, ainda, denunciar a ditadura e a corrupção dos

\footnotetext{
3 "(...) par l'absence de préjugés, d'idées préconçues dans ses relations avec les êtres et les événements ; / [qu'ils] ont sauvé I'une des plus grandes oeuvres de la littérature nègre de langue française". (GASSAMA, Makhily. La langue d'Ahmadou Kourouma ou le francais sous le soleil d'Afrique. Préface: Jean Ziegler. Paris: Karthala; ACCT, 1995, p. 18).
} 
governos que sucederam o colonizador. Portanto, a violação da língua francesa obedece à lógica interna do romance, tanto quanto ao compromisso autoimposto do autor em relatar a realidade política e cultural de seu país, a Costa do Marfim, na era das independências. Reconhecendo a função do rigor com o qual Ahmadou Kourouma opera a transgressão da norma culta da língua francesa, Gassama (1995) afirma que:

... as terríveis e violentas marcas que as "Independências" deixaram nos países africanos, recém-saídos da Colonização, outrora sorridentes e cheios de esperança, justificam amplamente a deplorável decadência moral e física dos seres que povoam Les soleils des Indépendances; veremos que se trata realmente de um mundo de desordens, retratado em um estilo deliberadamente desorganizado. ${ }^{4}$

Ao lado dessa leitura que concebe a hibridização lingüística como uma violação da norma culta da língua francesa que reforça a ruptura entre tradição e modernidade, uma outra conclusão recorrente nos estudos críticos relativos à obra Les soleils des Indépendances aponta o tema da esterilidade e da morte como símbolos da destruição efetiva da tradição. No entanto, nem sempre a crítica deixa claro se o que considera a morte da tradição se refere à decrepitude das instituições tradicionais ou ao desaparecimento de um conjunto de valores culturais. A nosso ver, essas duas possíveis apreensões da morte necessitam uma modalização, pois se as antigas instituições não participam da gestão das novas Nações, elas não desapareceram efetivamente e continuam a organizar as representações coletivas (BORGOMANO, 2000, p. 137). Quando observamos a atuação dos personagens e suas relações com os espaços, efetivos e simbólicos, da tradição e da modernidade, constatamos que a invasão estrangeira, a imposição de uma língua e a tentativa de suprimir a identificação autóctone com a tradição não foram suficientes para obter a

4 ... les terribles empreintes rageuses des "Indépendances" sur les pays africains, sortis de la Colonisation, naguère souriants et pleins d'espoir, justifient amplement la piteuse décandence morale et physique des êtres qui peuplent Les soleils des Indépendances; nous verrons qu'il s'agit bel et bien d'un monde de désordres, rendu dans um style volontairement désordonné. (GASSAMA, Makhily, op. cit., p. 21). 
adesão e a lealdade de todos indivíduos à nova ordem. Se tal abordagem atende a uma determinada visão do real, uma questão se impõe em função do acentuado grau de realismo do romance africano: que lugar Ahmadou Kourouma teria reservado dentro desse espaço ficcional àqueles que, confrontados ao meio cultural híbrido, conseguiram se adaptar e reorganizar seus sentimentos de pertença?

A verificação do grau de adaptação e da capacidade de negociação dos personagens, feita nos interstícios do hibridismo cultural, revelou-se, portanto, uma possibilidade instigante de análise. Assim, para fins de elucidação do simbolismo interno do romance (BUTOR, 2003, p. 12), e sua relação com o referente histórico que inspirou a elaboração da obra, analisamos os aspectos estético e temático do romance a fim de mostrar como a passagem da tradição à modernidade, além de levar o indivíduo a uma reorganização de sua identidade, anuncia de maneira subliminar um traço atribuído por Zygmunt Bauman à modernidade tardia, ou seja, a fluidez dos laços sociais e afetivos.

Com o intuito de esclarecer o grau de ruptura entre tradição e modernidade retratado por Kourouma, inscrevemos, na primeira parte da pesquisa, as bases da cultura malinké, os elementos referentes à biografia do autor e o resumo da obra, constituindo, assim, um bloco referencial sobre o qual se apóia a seqüência do trabalho. Na segunda, o processo evolutivo da ficção africana é analisado sob a perspectiva da incidência dos elementos constitutivos da narrativa tradicional no moderno romance africano em geral, e no romance Les Soleils des indépendances, em particular. A finalidade de avaliar as transformações sofridas pela narrativa africana, em sua passagem do oral ao escrito, consiste em evidenciar seus aspectos temáticos, formais e míticos que se contrapõem à concepção de mundo degradado que se reflete na obra. A terceira parte compreende, em primeiro lugar, uma leitura dos aportes teóricos que sustentam os princípios de reorganização identitária em meio de hibridismo cultural e complementam a noção baumaniana de sociedade sólida e sociedade líquida que guiou as análises do romance. Na seqüência, privilegiamos a verificação das rupturas internas que refletem a ascendência 
da estética da oralidade e da herança ocidental, de modo a demonstrar em que medida tais rupturas concorrem para a coerência interna da narrativa e, ao mesmo tempo, formam a base da reação dos personagens ao momento histórico no qual a natividade se sobrepõe aos laços de sangue como princípio de identificação.

Em resumo, o percurso que propomos visa avaliar em que medida o sujeito retratado na obra pôde ser capturado pela nova ordem, que destronou politicamente a tradição e elegeu a natividade como modo de legitimação e veículo de subordinação de seus indivíduos. 


\section{POLÍTICA, CULTURA E LITERATURA}

Nommer, c'est déjà connaître, répérer ce monde, les choses, les hommes, dans ce fatras nocturne de la vie, faire surgir donc l'être du néant : l'appeler à ce monde lourd, rugueux, palpable. Jean-Marie Adiaffi

\section{Kourouma: política e literatura}

Ahmadou Kourouma nasceu em Boundiali, no norte na Costa do Marfim, em 1927. Proveniente da etnia Malinké, seu nome, Kourouma, significa « guerreiro ${ }^{5} »$. Passou sua infância em Togobala que, mais tarde, viria a ser o vilarejo natal de Fama, personagem principal de Les soleils des Indépendances. Como conseqüência dos $\operatorname{conflitos}^{6}$ que separaram seus pais, Kourouma foi criado por um tio que o iniciou nas tradições de sua etnia malinké. Essas referências geo-culturais e religiosas que constituíram a sua

\footnotetext{
${ }^{5}$ Em Monnè, outrages et défis, segundo romance de Ahmadou Kourouma, baseado nos prejuízos gerados pelo encontro dos brancos com os negros durante a colonização, encontramos a seguinte referência ao clã dos Kourouma: Ce ministre, comme il se doit dans tout le Mandingue depuis Soundiata, était un descendant de Fakouli Kuruma, du clan des Kuruma, et portait le grand nom de Kuruma : I'honorable Kuruma Kélétigui. (KOUROUMA, Ahmadou. Monnè, outrages et défis. Paris: Seuil, 1990. p. 183).

${ }^{6}$ Em entrevista concedida a Vingonin Tinan Nina e Diandué Bi Kacou Parfait, Kourouma narra a história da separação familiar: seu pai, sendo caçador profissional, viajava de vilarejo em vilarejo e, em Beïla, encontrou uma mulher que tomou como segunda esposa. A mãe de Kourouma recusou-se a dividir a mesma casa com a segunda esposa; o casal se separou e a guarda dos filhos foi decidida pelo tribunal de Beïla: a mãe ficaria com a filha e Kourouma, com o pai. (Ahmadou Kourouma. Ahmadou Kourouma: Entretien [août 2000]. Réalisation: Vingonin Tinan Nina ; Diandué Bi Kacou Parfait. In: PARFAIT, Diandue $\mathrm{Bi}$ Kacou. Histoire et fiction dans la production romanesque d'Ahmadou Kourouma. 2003. Thèse (Doctorat en Sciences de l'Homme et de la Société) - Faculté des Lettres - Département de Littérature générale et comparée, Université de Limoges, Limoges. 2003). A disputa entre co-esposas, sendo um fato corriqueiro nas sociedades islâmicas, é uma presença constante nas literaturas africanas. Em Les soleils des Indépendances veremos a discórdia que o segundo casamento de Fama gerou entre Salimata, a primeira esposa, e Mariam.
} 
biografia, bem como seu engajamento político, marcariam profundamente sua obra; como sublinha Madeleine Borgomano (1998, p. 7), seu avô foi um dos grandes generais de Samory", o que o "inscreve nas colunas da resistência aos europeus e à colonização."

Kourouma cursou a Escola Primária de Bingerville (Costa do Marfim) e a Escola Técnica Superior de Bamako (Mali). Ao retornar à Costa do Marfim, é recrutado pelas forças armadas coloniais, mas a recusa em participar de um ato de repressão contra o R.D.A. (Rassemblement Démocratique Africain) caracteriza a indisciplina que o levaria a seu primeiro "exílio": Kourouma é enviado à Indochina no corpo de guerrilheiros senegaleses, onde vive de 1951 a 1954, exercendo a função de jornalista, pois era um dos raros soldados que sabia ler e escrever. Depois da experiência na Indochina, Kourouma segue para a França a fim dar continuidade à sua formação: ele é admitido no curso de construção aeronáutica e naval, mas é informado de que a África não tinha interesse nesse tipo de formação e que as bolsas de estudo para estudantes africanos só eram concedidas na medida em que a formação pudesse ser útil e gerar empregos na África. Kourouma decide, então, fazer o concurso para Ciências Atuariais, a única instrução que, segundo o B.U.S. (Bureau Universitaire de Statistique), ainda não estava saturada. Formou-se em Nantes e depois, fixou-se em Lyon, onde trabalhou como atuário e se casou com uma francesa. Naquela ocasião, Kourouma pretendia permanecer na França e fazer o curso de sociologia, como diria alguns anos mais tarde a Bernard Magnier (1987, p. 11). No entanto, o compromisso moral em relação à situação política de seu país levou-o a retornar à Costa do Marfim pouco antes da independência, obtida em 1960. Mas a independência representaria uma nova decepção e à luta anti-colonialista seguiu-se a luta contra os novos rumos da política encarnados no poder totalitário de Houphouët-Boigny.

Em 1963, Kourouma é preso, acusado de ter participado de um complô contra o presidente e só foi liberado depois que Houphouët considerou os

\footnotetext{
${ }^{7}$ Cf. importância de Samory no resumo histórico sobre o povo e a cultura malinké, p.
} 34. 
riscos de mantê-lo na prisão: sua mulher poderia alertar as autoridades francesas e provocar problemas diplomáticos ${ }^{8}$. Uma vez liberado, Kourouma passa sete meses em Abidjan sem emprego, pois as empresas foram proibidas de contratá-lo devido a seu envolvimento político e sua suposta participação no complô. Foi nesse momento que Kourouma começou a escrever seu primeiro romance Les soleils des Indépendances ${ }^{9}$, concebido inicialmente como uma denúncia contra os abusos da tirania e da corrupção.

O romance relata a opressão gerada pela independência do país e pela imposição do partido único. O personagem principal, Fama Doumbouya, príncipe do Horodougou, foi despojado de seu título, de seus bens e, agora, sob "os sóis das independências", vaga de funeral em funeral, recolhendo os donativos das cerimônias que constituem seu único meio de sobrevivência. 0 príncipe reduzido à mendicância representa a falência social e econômica do indivíduo Fama e, por extensão, a supressão da sociedade tradicional africana, que sucumbe sob o peso dos novos valores trazidos com a colonização e perpetrados com a independência.

\footnotetext{
${ }^{8}$ Vale lembrar que as independências dos países colonizados pela França ocorreram devido à pressão internacional, sobretudo por parte da Inglaterra. Além disso, a independência política não significou a ruptura definitiva dos laços que uniam excolônia e metrópole. Ao contrário, ao deixar a cena colonial, a França deixou in loco personagens que agiam com mão de ferro na administração dos países independentes e se sentiam tributários do ex-colonizador. Segundo Bernard Ahua, a descolonização na Costa do Marfim, mais do que em qualquer outro país, foi fortemente enquadrada por Paris no que se refere ao sistema econômico e financeiro, dividindo o mercado entre três pesos pesados da rede bancária: La Société Générale, rebatizada como Société Générale des banques de Côte d'Ivoire; a Société ivoirienne de banque, filial do Crédit Lyonnais; e La Banque Internationale pour le Commerce et I'Industrie de Côte d'Ivoire, filial da Banque Nationale de Paris. (AHUA, Bernard. La France se taille la part du Lion dans l'économie ivoirienne. In : LE MONDE DIPLOMATIQUE : Manière de voir 79. Résistences africaines. Paris, [s.n.], n. 79, fév.-mars 2005, p. 85).

9 As datas que compreendem o início e o fim da redação do romance não são coincidentes nas obras de crítica e história literária que foram consultadas. JeanClaude Nicolas (1985, p. 4) atribui seu início ao ano de 1961; Barthélémy NGuessan Kotchy situa a elaboração da obra entre 1960 e 1965; no mesmo volume em que é publicado o artigo de Kotchy, encontramos ainda a referência 1961 e 1965 . Optamos pelo ano de 1963 segundo declaração do próprio autor, que afirma ter começado a redigir logo após ter sido acusado de participar do falso complô contra HouphouëtBoigny, em 1963.
} 
Depois de ter sido recusado por várias editoras francesas por não corresponder aos padrões da norma culta da língua francesa, Les soleils des indépendances recebeu o Prix de la francophonie du Québec e foi publicado pelas Presses Universitaires du Canada. Não se sabe ao certo quais foram essas editoras; sabe-se apenas que as Éditions du Seuil, que comprariam os direitos de publicação após o sucesso da obra editada no Canadá, teriam rejeitado o manuscrito devido às "incorreções" da língua francesa. Além da questão temática que envolve o abuso do poder tirânico e a espoliação dos direitos do cidadão, corolário e conseqüência do período colonial, a introdução de estruturas lógico-cognitivas da língua malinké no francês mobilizou grande parte da crítica referente ao romance. A esse respeito, Tanela Boni sublinha as dificuldades do autor:

Kourouma confessa ter sido confrontado com este problema fundamental da língua, este corpo a corpo com as palavras. Ele sentia sua impotência em encaixar seus personagens no padrão da língua francesa. Foi então obrigado a traduzir o "intraduzível". Mas traduzir não significava uma transposição literal. Traduzir aqui significa encontrar o meio adequado para transmitir todo um pensamento, introduzir uma expressão, transferir a língua materna, o malinké, com suas cores, suas cargas emocionais e suas imagens para a língua escrita. ${ }^{10}$

A fortuna crítica da obra viria então a estabelecer quase um consenso em torno do termo viol - em seu amplo espectro de violação, constrangimento, violência e transgressão - para qualificar a inserção de estruturas sintagmáticas, de um estilo e um léxico completamente extrínsecos à língua francesa.

${ }^{10}$ Kourouma avoue avoir été confronte à ce problème fondamental de la langue, ce corps à corps avec les mots. Il sentait sa faiblesse à faire entrer ses personnages dans le moule de la langue française. Il a été obligé de traduire "l'intraduisible ». Mais traduire ce n'est pas faire du mot à mot. Traduire ici c'est trouver le moyen adéquat pour faire couler toute une pensée, faire glisser une expression, transférer la langue maternelle, le malinké avec ses couleurs, ses charges émotionnelles, ses images, dans la langue d'écriture. (BONI, Tanella. Écrivains et artistes francophones: pour qui ? Et pour quoi ? In: HUANNOU, Adrien (Textes réunis par). Francophonie littéraire et identités culturelles: Actes du colloque du Grelef (Cotonou, 18-20 mars 1998). Paris: L'Harmattan, 2000. p. 164). 
Depois da prisão pela participação no complô contra Houphouët-Boigny e dos vários meses de ócio passados em Abidjan, Kourouma decidiu retornar à França, obtendo, por meio da Associação dos atuários, uma colocação na Argélia. Foi apenas em 1970 que Kourouma pôde retornar à Costa do Marfim, quando, finalmente, ficou provado que a conspiração havia sido um golpe para cercear e comprometer os rebeldes. Neste ano, ele comporia uma peça de teatro que, por seu conteúdo revolucionário, o afastaria uma vez mais de seu país: Tougnantigui ou le diseur de vérité ${ }^{11}$. Na verdade, o "falador de verdades" é uma referência mal dissimulada a Houphouët-Boigny. Segundo o autor, tratava-se de uma peça de circunstância. Mentia-se muito na Costa do Marfim. Eram tempos da guerra fria, tudo se baseava na mentira e tinham conseguido fazer com que os jovens acreditassem que Houphouët era imortal, uma espécie de deus ${ }^{12}$. A citação de um trecho do Prólogo da peça talvez seja suficientemente eloqüente para compreendermos as razões de mais um exílio:

LE CLAN DES PRIVILÉGIÉS (ensemble) - Admirez la marque distinctive d'honorabilité que chacun de nous exhibe. Le diseur de vérité a comblé chacun de nous de richesses et de qualités. Nous sommes des privilégiés; des amis, des parents, des gens de la tribu, des proches du diseur de vérités. Nous croyons.

LE CLAN DES DÉMUNIS - Nous constituons la multitude; les autres, les travailleurs et les chômeurs; les affamés, les toujours trompés. Nous sommes nés loin et étrangers au diseur de vérité.

[...]

DJELIBA - Au départ comment étions-nous?

LES DEUX CLANS (ensemble) - Nous étions frères. (Il se rapprochent et se mêlent). Nous étions unis. Parce que nous étions un, nous nous

${ }^{11} \mathrm{Na}$ ocasião, a peça não chegou a ser divulgada. Madeleine Borgomano diz, em Ahmadou Kourouma - Le "guerrier" griot (1998, p. 9), que Le diseur de vérité nunca mais havia sido editada, mas no mesmo ano de publicação de seu livro a peça seria relançada pela Acoria, na coleção Scènes sur Scènes, dirigida por Sylvie Chalaye. Nessa edição, a primeira parte do título foi suprimida, reduzindo-se apenas a Le diseur de vérité.

${ }^{12}$ C'était une pièce de circonstance. En Côte d'Ivoire, on mentait beaucoup. C'était la guerre froide, tout était assis sur le mensonge et on était parvenu à faire croire à des jeunes que Houphouët était immortel, une sorte de dieu. (Ahmadou Kourouma. Rencontre avec Ahmadou kourouma. Entretien [mars 2003]. Réalisation : François Xavier. Disponível em: <http://www.francoisxavier.net/article.php3?id article=33 > . Acesso em: 05 jan. 2006). 
aimions, nous étions heureux. Notre ciel gorgeait d'interminables hivernages, nos terres d'abondantes récoltes, nos femmes d'innombrables enfants.

DJÉLIBA - Les échos de nos tam-tams de fête, de nos cris de joie, de nos chants; l'éclat de nos sourires, de nos bijoux dorés et surtout le vol puissant de nos oiseaux migrateurs qui venaient glaner nos champs et repartaient gavés de grains jusqu'au gosier vers le désert brûlant.

LES DEUX CLANS - Tout cela appela, dirigea les occupants. I/s conquirent notre pays, s'approprièrent nos récoltes et nos terres, nous vendirent comme esclaves ; alors débuta une interminable damnation.

DJÉLIBA - Tout changea dans notre pays; le ciel sécha de ses pluies; les récoltes réfusèrent de pousser; le désert de soif, de faim, de vent, nous environna. Nos sourires et nos matins perdirent leur éclat; nos chants, nos tam-tams, tous nos arts perdirent leur poésie. Nos villages dépeuplèrent quoique nos mères fussent occupées sans cesse par les maternités; nos cases tombaient en ruine quoique nos hommes s'employassent sans cesse à les reconstruire. En vérité tout devint ségué; ségué signifie la peine sans profit. Notre pays devint Séguédougou: terre des peines; notre race, Séguétos: hommes de peine, esclaves. Dans un monde sans horizons, un monde impossible, nous avons rêvé. ${ }^{13}$

Após a representação da peça, as autoridades alertaram HouphouëtBoigny sobre o conteúdo subversivo do texto: Kourouma perde seu emprego e é enviado a Yaoundé, Camarões, onde permaneceria durante dez anos e, depois disso, a Lomé, no Togo, onde também ficaria por mais dez anos. Ao todo, esses vinte anos correspondem exatamente ao tempo que separa Les soleils des Indépendances de Monnè, outrages et défis, seu segundo romance, publicado em $1990^{14}$.

Em Monnè, outrages et défis, o autor recua no tempo e narra a descoberta da África pelos europeus, colocando em evidência a degradação gerada pela colonização e os conflitos interculturais. Djigui, vítima de sua ingenuidade, perde o reino de Soba e assiste à implantação de novos valores do homem branco em terras que outrora comandava dentro dos costumes

\footnotetext{
${ }^{13}$ KOUROUMA, Amadou. Le diseur de vérité. Chatenay-Malabry: Accoria, 1998b. p. 11-12.

${ }^{14}$ Durante todos esses anos que separam os dois romances, os leitores e críticos de Kourouma chegaram a pensar que ele seria mais um autor de um único romance, a exemplo de Yambo Ouologuem, com Le devoir de violence (1968), ou Cheikh Amidou Kane que, depois de Aventure ambiguë (1961), levou 35 anos para publicar Les Guardiens du Temple (1996).
} 
tradicionais. Djigui, como Fama, era analfabeto e não pôde compreender a astúcia do colonizador $^{15}$. O romance encerra, como pano de fundo, uma reflexão a respeito do imperialismo europeu e da colaboração. Para os que aguardaram com uma certa ansiedade o segundo romance do escritor de Les soleils des Indépendances, o livro revelou-se um tanto decepcionante em relação à sua realidade estética: se, por um lado, a ficção remodela a narrativa tradicional, por outro, a língua não mais reflete a inovação do primeiro romance. $O$ autor explica a alteração de seu estilo pelos longos anos de exílio, que fizeram com que deixasse de pensar em malinké ${ }^{16}$.

Para retomar uma expressão recorrente em suas criações, au soir de sa vie, já aposentado, Kourouma acelera o ritmo de sua produção literária, publicando, em 1998, En attendant le vote des bêtes sauvages e, em 2000, Allah n'est pas obligé.

Inspirado em Eyadéma, presidente do Togo, Kourouma retraça a vida do tirano Koyaga em En attendant le vote des bêtes sauvages, título que, contrariamente aos dois romances anteriores, não faz referência direta à língua malinké, mas surpreende pelo apelo beckettiano e pelo inusitado da fórmula "vote des bêtes sauvages"17. Indignado com a afirmação dos europeus de que os países da antiga União Soviética haviam sido os únicos a padecer os regimes ditatoriais, o autor se pergunta em que nichos teriam sido depositados os mortos e o sofrimento do povo africano oprimido pelos piores tiranos após a independência e durante a guerra fria. Kourouma tenta trazer uma resposta a esta questão e resume a origem de seu terceiro romance como "um livro que emerge de uma "cólera"18.

\footnotetext{
${ }^{15}$ Veremos no capítulo "Da cheferia tradicional à administração colonial" os métodos de sedução que foram usados para angariar simpatizantes autóctones à causa européia.

${ }^{16}$ Cf. entrevista concedida a Vingonin Tinan Nina e Diandué Bi Kacou Parfait, em 9/08/2000. In: Histoire et fiction dans la production romanesque d'Ahmadou Kourouma - Thèse de doctorat soutenue à I'Université de Limoges, 2003.

${ }^{17} \mathrm{Cf}$. BORGOMANO, Madeleine. Un roman fécondé par un chant de chasseurs. In: Des hommes ou des bêtes: Lecture de En attendant le vote des bêtes sauvages, d'Ahmadou Kourouma. Paris: L'Harmattan, p. 15-37.

${ }^{18}$ Cf. entrevista supracitada [mars 2003].
} 
Koyaga é o ditador que consegue manter-se no poder pelo exercício da tirania e da corrupção. É graças a seus aliados pessoais - sua mãe Nadjouma e seu marabu - que Koyaga consegue a proteção necessária para escapar aos complôs urdidos para derrubá-lo. Descrevendo um perfil cujo esboço já se encontrava em Les soleils des Indépendances na figura do presidente e do regime que condena arbitrariamente Fama, o autor traz à cena literária o donsomana do ditador Koyaga: a narrativa purificatória de sua vida como mestre caçador e ditador (KOUROUMA, 1998, p. 10). Do ponto de vista estético, En attendant le vote des bêtes sauvages recupera a forma da epopéia tradicional na qual o griot evoca os grandes feitos dos heróis, legitimados pela genealogia. Do ponto de vista temático, trata-se da denúncia dos males que atingiram a África com seus ditadores que, tal qual Koyaga, ainda permanecem no poder (...) ou foram substituídos por equivalentes. ${ }^{19}$

Sob um outro ângulo, em Allah n'est pas obligé, Birahima, um menino de dez ou doze anos, ele não sabe ao certo, toma a palavra e narra seu percurso de criança órfã e sem escolarização, obrigada a tornar-se uma das crianças-soldado que exibem sua Kalachnikov em meio às guerras tribais. $\mathrm{Na}$ voz do jovem Birahima, Kourouma denuncia a extrema violência das guerras do oeste africano, sobretudo em Serra Leoa, e a obscenidade do recrutamento infantil $^{20}$. O romance ilustra, portanto, a atualidade de uma África marcada

19 ... sont toujours au pouvoir (...) ou ont été remplacés par des equivalents. (BORGOMANO, Madeleine. Des hommes ou des bêtes: Lecture de En attendant le vote des bêtes sauvages, d'Ahmadou Kourouma. Paris: L'Harmattan, 2000. p. 188.

${ }^{20}$ Kassimi Bamba (2005) descreve a situação atual das crianças que continuam sendo recrutadas para combater nas forças governamentais e nos exércitos rebeldes: Uma vez recrutados, devem executar uma série de tarefas. Se muitos participam dos combates, outros são utilizados para fins sexuais ou como espiões, mensageiros, carregadores ou usados no serviço doméstico. Alguns devem, ainda, montar e desmontar minas terrestres. Uma tal exploração das crianças que gera, ao mesmo tempo, conseqüências para a sociedade e para as próprias crianças, continua sendo feita impunemente e com total desprezo pelas regras de direito internacional. [Une fois enrôlés, ils doivent s'acquitter de toute une série de tâches. Si beaucoup prennent part aux combats, d'autres sont utilisés à des fins sexuelles ou comme espions, messagers, porteurs ou domestiques. Certains doivent également poser ou enlever des mines terrestres. Une telle exploitation des enfants qui développe à la fois des conséquences sur la société et sur les enfants eux-mêmes continue de se faire en toute impunité et au mépris des règles de droit international]. (BAMBA, Kassimi. Le drame des enfants 
pelas guerras sanguinolentas, ligando uma vez mais a História da África às mutações do fazer literário e abrindo-se para uma violência que não deixa espaço à recepção indiferente.

Ahmadou Kourouma morre em 11 de dezembro de 2003, deixando um romance inacabado ${ }^{21}$. Quand on refuse, on dit non foi publicado nove meses após a sua morte pelas Éditions du Seuil. Nesse novo romance, Kourouma preparava a continuação das aventuras de Birahima: agora desmobilizado, segue a bela Fanta em sua fuga para Bouaké, depois de um massacre em Daloa, cidade onde viviam, no sul da Costa do Marfim. Um deslocamento e uma situação geográfica absolutamente convenientes a seu propósito: narrar a realidade e o caos de seu país minado pela guerra civil. Infelizmente, não saberemos que rumo teriam tomado Birahima e Fanta depois de sua chegada a Bouaké, mas sabemos, pelos documentos anexos publicados, que Kourouma ainda não havia decidido qual seria a melhor solução para concluir um romance baseado na história de um conflito que ainda não tinha chegado ao fim. Em nota à edição póstuma, Gilles Carpentier conclui:

Escrevendo este livro com urgência (oito meses ininterruptos de trabalho), ele próprio submetido a um exílio cuja fatalidade não queria admitir, Ahmadou Kourouma sabia que ele não estava criando apenas uma obra literária. Muito mais do que os outros livros, este se inscrevia numa perspectiva política e cívica. ${ }^{22}$

soldats en Afrique. In : DÉBATS : Courrier de I'Afrique de I'Ouest. Abidjan : CERAP/ Inades, n. 22, fév. 2005. p. 21).

${ }^{21}$ Além das obras citadas, Kourouma também se dedicou à literatura infanto-juvenil em livros que revelam a cultura e os costumes da tradição africana. São elas: Yacouba, le chasseur africain. Gallimard-Jeunesse, 1998 ; Le chasseur, héros africain. Grandir, 1999 ; Le griot, homme de parole. Grandir, 1999 ; Le forgeron, homme de savoir e Le prince, suzerain actif, ill. Giorgio Bacchin, Grandir, 2000.

${ }^{22}$ En écrivant ce livre dans I'urgence (huit mois de travail ininterrompu), lui-même contraint à un exil dont il ne voulait pas admettre la fatalité, Ahmadou Kourouma savait qu'il ne faisait pas seulement une oeuvre littéraire. Plus encore que ses autres livres, celui-ci s'incrivait dans une perspective politique et civique. (CARPENTIER, Gilles. In : KOUROUMA, Amadou. Quand on refuse on dit non. Texte établi par Gilles Carpentier. Paris: Seuil, 2004. p. 145). 
O advento da literatura na vida de Kourouma foi algo de inesperado. Como vimos acima, seu desejo inicial era dedicar-se à sociologia devido à decepção com os estudos etnográficos e sociológicos sobre a África ${ }^{23}$. A necessidade de expor, de "testemunhar" e denunciar as mazelas políticas da África causadas pelos europeus é um argumento recorrente nos depoimentos e palestras que concedeu; seus livros nasceram, portanto, de um imperativo político e ideológico, mas como observou Patrick Granville, Kourouma não é nem sociólogo, nem historiador, nem moralista patenteado. É um imenso romancista que, sem pathos, monta e desmonta sua mecânica dos monstros. ${ }^{24}$

Kourouma não foi o único a expressar o anseio de testemunhar. Tahar Ben Jelloun ${ }^{25}$ fez uma declaração semelhante, mas acrescentou que seu recuo frente às questões históricas e políticas propriamente ditas deveu-se à distinção, cada vez mais nítida, entre militantismo e atividade literária. De qualquer forma, independente dos depoimentos do autor, a obra de Kourouma não foge à regra no que se refere à necessidade de toda uma geração de escritores, ou seja, fazer da literatura um instrumento de meticulosa avaliação dos regimes políticos tirânicos e depreciar os dirigentes que se encontravam no poder. É nesse sentido que Romuald Fonkouya avalia o discurso literário dos anos subseqüentes às independências:

${ }^{23}$ A literatura como veículo de informação etnográfica e sociológica tornou-se uma constante no continente africano, ameaçado com o descrédito de sua cultura após a colonização. Um exemplo de iniciativa neste sentido foi a revista cabo-verdiana Claridade. Segundo Pierre Rivas, os claridosos pretendiam instaurar uma literatura de fundação na qual a busca identitária se traduz pela importância do levantamento etnográfico, a compilação dos contos e legendas populares, a valorização do folclore, em uma palavra, a elaboração de uma mitopoética nacional. (RIVAS, Pierre. Claridade. Emergence et différentiation d'une littérature nacionale. L'Exemple du Cap Vert. Quadrant 6. Monpellier, déc. 1986, p. 109-118).

${ }^{24}$ GRANDVILLE apud BORGOMANO. In: BORGOMANO, 2000, op. cit., p. 39.

${ }^{25}$ Entrevista concedida a Denise Brahimi. (BRAHIMI, Denise. Conversation avec Tahar Ben Jelloun. In: NOTRE LIBRAIRIE : Revue du livre: Afrique, Caraïbes, Océan Indien. 1980 - 1990 : Dix ans de Littérature : I. Maghreb - Afrique Noire. Paris : Clef, n. 103, oct.-déc. 1990 , p. 43). 
Desde Les soleis des Indépendances, as sociedades situadas em torno do "cercle des tropiques" ${ }^{26}$ vivem sob regimes políticos tirânicos que governam por meio do terror e da violência. (...) Podemos considerar, sem risco de nos equivocarmos, que o poder ou a situação política continua sendo o espaço mais freqüente desta escritura. Uma avaliação do conteúdo dos romances publicados nos anos 70 nos permite constatar que os escritores denunciaram sob todos os tons os sistemas dos partidos únicos: cantando com uma ironia mordaz os "Viva o Presidente"; denunciando os avatares da democracia; erigindo as acusações aos partidos únicos (todos iníquos); desvendando os sistemas de enquadramento ideológico; ridicularizando o confisco do poder por uma elite nacional incompetente e corrupta; narrando os múltiplos e sucessivos reveses dos heróis em busca de um universo novo para seu povo e relegados ao esquecimento do tempo que passa, habituando o povo à infelicidade, Fantouré, Sassine ou Beti elaboravam, através da escritura romanesca, um ato de denúncia e uma construção do possível. $^{27}$

A denúncia e a crítica aos regimes políticos, aos partidos únicos e à ideologia dos regimes tirânicos, todos esses elementos formaram aspectos importantes da geração dos escritores independentes, que deram as costas a uma literatura de anuência ao modelo europeu e à alienação cultural e identitária incentivadas pela colonização. Dedicando-se à prosa romanesca neste momento de transição política, Kourouma alia em seu primeiro romance a ambição de testemunhar a degradação causada pelos europeus à consciência

\footnotetext{
${ }^{26}$ Menção ao romance Le Cercle des tropiques, de Alioum Fantouré. Paris: Présence Africaine, 1972. 315 p.

27 Depuis Les soleis des Indépendances, les sociétés situées autour du « cercle des tropiques » vivent sous des régimes politiques tyranniques qui règnent para la terreur et la violence. (...) On peut sans risque de se tromper considérer que le pouvoir ou la situation politique reste le lieu le plus fréquent de cette écriture. Un aperçu du contenu des romans publiés au cours des années 70 nous permet de constater que les écrivains ont dénoncés sur tous les tons les systèmes des partis uniques : en chantant avec une ironie mordante les «Vive le Président »; en dénonçant les avatars de la démocratie ; en dressant le réquisitoire des partis uniques (tous iniques); en dévoilant les systèmes d'encadrement idéologique; en raillant la confiscation du pouvoir par une élite nationale incompétente et corrompue; en narrant les défaites multiples et successives des héros à la quête d'un univers nouveau pour leur peuple et sombrés dans l'oubli du temps qui passe en habituant le peuple au malheur, Fantouré, Sassine ou Beti élaboraient à travers l'écriture romanesque un acte de dénonciation et une construction du possible. (FONKOUYA, Romuald. Dix ans de littérature africaine : pouvoir, société et écriture. In : NOTRE LIBRAIRIE : Revue du livre: Afrique, Caraïbes, Océan Indien. 1980 - 1990 : Dix ans de Littérature : I. Maghreb - Afrique Noire. Paris : Clef, n. 103, oct.-déc. 1990, p. 71).
} 
de dever cívico de exibir a negligência, e irresponsabilidade e a violência dos regimes políticos das independências. Isso equivale a dizer que, ao acertar também os alvos africanos, empreende uma crítica bilateral:

Não se pose tomar posse da História e fazer dela o que fazia a Negritude. Ou seja, apresentar apenas os lados positivos. Ela tinha suas razões para isso. Nós não fazemos isso porque a História é um todo. ${ }^{28}$

O referencial histórico é, de fato, bastante nítido na obra de Kourouma. Em Les soleils des Indépendances, afora a evidência do período demarcado pelo título, a alusão à política de Houphouët-Boigny pode ser identificada sem grande esforço:

Le secrétaire général et le directeur, tant qu'ils savent dire les louanges du président, du chef unique et de son parti, le parti unique, peuvent bien engouffrer tout l'argent du monde sans qu'un seul oeil ose ciller dans toute I'Afrique. ${ }^{29}$

Il inculpa Fama de participation à un complot tendant à assassiner le président et à renverser la république de la Côte des Ébènes. ${ }^{30}$

A referência à permissividade e ao fisiologismo do então presidente de seu país, bem como ao "falso complô" armado contra Kourouma e seus amigos de luta política, são tão evidentes nos trechos acima citados que dispensam a evocação da identidade civil dos envolvidos. Kourouma, aliás, manifestou seu

${ }^{28}$ On ne peut pas prendre l'Histoire, en faire ce que la négritude en faisait. C'est-à-dire ne présenter que les bons côtés. Elle avait des raisons de le faire. Nous, nous ne le faisons pas parce que I'Histoire c'est un tout. (KOUROUMA, Ahmadou. Ahmadou Kourouma: Entretien [juin 2002]. Réalisation: Diandué Bi Kacou Parfait. In: PARFAIT, Diandue $\mathrm{Bi}$ Kacou. Histoire et fiction dans la production romanesque d'Ahmadou Kourouma. 2003. Thèse (Doctorat en Sciences de l'Homme et de la Société) Faculté des Lettres - Département de Littérature générale et comparée, Université de Limoges, Limoges. 2003. Disponível em : <http://www.unilim.fr/theses/2003/lettres/2003limo0002/these.html>. Acesso em: 10 jul. 2005. Não paginado).

${ }^{29}$ KOUROUMA, Ahmadou. Les soleils des Indépendances. Paris: Seuil, 1970. p. 25. Daqui por diante, a abreviação LsdI será utilizada como referência das citações do romance Les soleils des Indépendances.

${ }^{30}$ KOUROUMA, LsdI, op. cit., p. 166. 
desejo de empregar os nomes de personalidades históricas nas quais se inspirou (Houphouët-Boigny, Gbon Coulibaly, Mobutu, Hassan II, Bokassa ou Eyadéma) ${ }^{31}$, mas as implicações jurídicas que seriam a decorrência natural deste procedimento o levaram a substituir a menção direta pelo nome de alguns totens. Assim, oficialmente, não se trata de dirigentes africanos. ${ }^{32}$

Se a História pode ser facilmente identificável como lugar do discurso literário em Kourouma, a insistência neste aspecto também gerou equívocos para o próprio autor quanto às inúmeras explicações que, ao longo dos anos, foram sendo exigidas com relação à sua obra. Claro está que não cabe ao autor o trabalho de exegese de sua obra, mas a solicitação de esclarecimento sempre acompanhou, em maior ou menor grau, o empenho da crítica em elucidar a atividade estética, que, independente do método de análise, procura desvendar os segredos da criação literária. Tomando de empréstimo a expressão de Tanela Boni (2000, p. 164), ao lado desse corpo a corpo com as palavras, Kourouma deparou-se também com um corpo a corpo com a crítica. Mesmo tendo dito várias vezes que sua formação em exatas não o autorizava a discorrer sobre questões de teoria literária, que sua apreensão da criação remontava à práxis pessoal, as questões relativas à sua realidade estética sempre retornavam. Restava-Ihe então, não sem prejuízo para os julgamentos de valor a respeito do escritor, o apelo instintivo à sua realidade "cognitiva e ética":

Escrevo coisas que são verdadeiras. Não escrevo para defender uma teoria, uma ideologia política, uma revolução, etc. Escrevo verdades

\footnotetext{
${ }^{31}$ Houphouët-Boigny: presidente da Costa do Marfim da Independência do país, em 1960, até sua morte, em 1993; Mobutu: presidente do Zaire a partir do golpe de 1965, mantendo 30 anos de ditadura; Hassan II: chefe espiritual e dirigente que consolidou o poder absolutista no Marrocos; Bokassa: ditador da República Centro Africana, de 1966 a 1979, quando foi deposto; Eyadéma: presidente do Togo, onde viveu Kourouma durante dez anos.

32 Oficiellement, il ne s'agit pas de dirigeants africains. (KOUROUMA, Ahmadou. Ahmadou Kourouma : Entretien [oct. 1999]. Réalisation : Thibault Le Renard; Comi M. Toulabor. In : Politique Africaine, Paris, n. 75, oct. 1999, p. 178.
} 
como eu as concebo, sem tomar partido. Escrevo as coisas como elas são. ${ }^{33}$

A nos determos nas declarações de Kourouma, seríamos impelidos a recordar a reefetuação do passado no presente que Paul Ricoeur atribui à articulação intelectual que anima o historiador: a operação que surge como uma des-distanciação, uma identificação com o que outrora foi ${ }^{34}$ ou a reconstrução viva do rastro que torna contemporâneos os acontecimentos passados. Não há como negar que Kourouma efetua em dados momentos tal operação $^{35}$, mas como escritor, e não historiador, a leitura estética há de prevalecer, fato que, aliás, o próprio autor, em suas hesitações, admite:

O que eu conto não é a História, considero as bases históricas sobre as quais escaneio os fatos que eu narro. (...) É a minha ficção, é a minha leitura da História [...] Quando um romancista trabalha, ele sempre se baseia num personagem. Ele sempre começa por um personagem real e, depois, o transforma. ${ }^{36}$

A distinção entre narrativa histórica e narrativa de ficção torna-se então mais nítida para Kourouma, mas a resposta talvez mais eficaz sobre sua atividade literária talvez tenha sido a que forneceu a Bernard Magnier:

Eu penso muito antes de escrever. No momento em que escrevo, o problema de saber onde quero chegar não existe mais. Conheço os personagens. Conheço a atmosfera. Resta-me a escritura, ou seja, encontrar as palavras exatas que me permitirão levar o leitor a viver plenamente a cena exposta. Um romance é uma seqüência de eventos e

33 J'écris des choses qui sont vraies. Je n'écris pas pour soutenir une théorie, une idéologie politique, une révolution, etc. J'écris des vérités, comme je les ressens, sans prendre parti. J'écris les choses comme elles sont. (KOUROUMA, 1999, idem, p. 178).

${ }^{34}$ RICOEUR, Paul. Tempo e narrativa. Tomo III. Tradução: Roberto Leal Ferreira; revisão técnica: Maria da Penha Villela-Petit. Campinas: Papirus, 1997. p. 244.

${ }^{35}$ Uma excelente análise a esse respeito pode ser encontrada em PARFAIT, Diandue Bi Kacou, 2003, op. cit.

${ }^{36} \mathrm{Ce}$ n'est pas l'Histoire que je raconte, je prends les bases historiques sur lesquelles je scanne les faits que je raconte (...) C'est ma fiction, c'est ma lecture de l'Histoire (...) Quand un romancier travaille, il se base toujours sur un personnage. Il commence toujours par un personnage réel et après il le transforme. (KOUROUMA, Ahmadou. Ahmadou Kourouma: Entretien [juin 2002]. Réalisation: Diandué Bi Kacou Parfait. In: PARFAIT, Diandue Bi Kacou, 2003, op. cit., não paginado). 
é a maneira de narrar que torna a história interessante ou banal. Dentro dessa perspectiva, o cinema é um modelo para mim. ${ }^{37}$

De fato, como afirmou Kourouma, seu objetivo não era defender uma teoria ou fornecer dados para uma metodologia de leitura e análise de sua obra, mas talvez tivesse se poupado dos constrangimentos da crítica se, ao invés de se justificar perante o ocidente, tivesse adquirido a autonomia sugerida por Maryse Condé (1977, p. 29), ou seja, a descolonização intelectual que abre os caminhos para uma teorização dos campos literários africanos.

No que se refere ao primeiro romance de Kourouma, a severidade da crítica talvez tenha sido ainda mais cruel, pois à parte a solicitação de explicações relativas ao comprometimento histórico, à indefinição de um gênero híbrido que recorre à narrativa heróica ou mesmo à escolha de um personagem não representativo da maioria dos africanos, o alvo maior foi sem dúvida a questão da linguagem e do estilo.

Ahmadou Kourouma foi, por diversas vezes, criticado em razão de sua "escolha" por um personagem retrógrado, permanentemente em busca da restauração de uma raiz ou comunidade de pertença única: um perfil a contrapelo do respeito ao Diverso ${ }^{38}$ e da metáfora do rizoma ${ }^{39}$ como forma de entender o múltiplo na relação. Mas em sua defesa concorre a análise e ponderação de alguns intelectuais que apontam a necessidade de se retratar o povo africano de maneira global, com sua experiência ampla e proteiforme, suas grandezas e também sua fraquezas:

37 Je refléchis beaucoup avant d'écrire. Au moment où j'écris, le problème n'est plus du tout de savoir où je vais aller. Je connais les personnages. Je connais l'atmosphère. Il me reste l'écriture. C'est-à-dire trouver les mots justes qui me permettront d'amener le lecteur à vivre pleinemet la scène exposée. Un roman c'est une suite d'événements et c'est la façon de raconter qui rend l'histoire intéressante ou banale. Dans cette perspective de visualisation, le cinéma reste un modèle pour moi. (In : MAGNIER, Bernard. Ahmadou Kourouma. In: NOTRE LIBRAIRIE : Revue du livre Afrique noire, Maghreb, Caraïbes, Océan Indien. Littérature de Côte d'Ivoire II: Écrire aujourd'hui. Paris : Clef, n. 87, avr.-juin 1987. p. 12).

38 Cf. GLISSANT, Édouard. Le discours antillais. Paris: Gallimard, 1997a.

39 Cf. DELEUZE, Gilles; GUATARRI, Félix. Mille plateaux: Capitalisme et Schizophrénie. Paris: Minuit, 1980. 
Hoje, o intelectual africano, se pretende mostrar-se responsável em suas relações com seu povo, que está mergulhado numa crise indescritível, deve esquivar-se de uma certa imagem da África que tentam Ihe impor do exterior, deve aprender a pensar por si mesmo, realizar pesquisas sobre a África e os africanos, desviando-se também de alguns sonhos: a ilusão de um passado idílico. ${ }^{40}$

Quanto à singularidade do discurso literário cuja escritura faz a língua francesa curvar-se às necessidades do pensamento e da expressão malinké, esta foi considerada, como dissemos anteriormente, como uma violação, uma transgressão e violência à língua francesa. Não fica difícil imaginar sob qual ângulo o texto de Kourouma foi considerado para que tais substantivos sintetizassem a dupla inscrição lingüística de Kourouma em Les soleils des Indépendances. A imagem de violação é agressiva e não deixa de denotar o crime: ironicamente, o autor inverte a posse do poder e subjuga a língua francesa. Como imagem que melhor se adapta à orientação deste trabalho, preferimos, ao termo violação, a irônica metáfora da "fiel traição" elaborada por Makhily Gassama (1995):

Ahmadou Kourouma tortura e trai a língua francesa como quem pretende manter-se fiel à linguagem malinké com a qual parece ter "jurado uma santa aliança". Este bígamo é injusto e criminoso: ele incendeia um de seus lares; emprega as palavras da França para nelas inserir o pensamento de sua floresta natal; ele as destrói para destituílas de qualquer valor e, progressivamente, as preenche com novos valores, que são os da sua região e que, às vezes, fazem as palavras brilharem como pepitas de ouro. ${ }^{41}$

40 L'intellectuel africain d'aujourd'hui, s'il veut se montrer responsable dans ses rapports avec son peuple qui est plongé dans une crise indescriptible, doit se défier d'une certaine image de l'Afrique qu'on tente de lui imposer du dehors, il doit apprendre à penser par lui-même, entreprendre lui-même des recherches sur l'Afrique et les Africains en se défiant, là aussi de certains rêves : I'illusion d'un passé idyllique. (ZADI ZAOUROU, Bernard. La parole poétique dans la poésie africaine: domaine de l'Afrique de l'ouest francophone. 1981. Thèse (Doctorat d'État) - Lettres et Sciences Humaines - Université de Strasbourg II, Strasbourg. 1981. p. 195).

${ }^{41}$ Ahmadou Kourouma torture et trahit la langue française, comme pour démeurer fidèle au langage malinké avec lequel il semble avoir «juré une sainte alliance». Ce bigame est injuste te criminel : il met le feu à l'un de ses foyers. Il emploie les mots de France pour y couler la pensée de sa forêt natale. Il les fait éclater pour les vider de toute valeur et, rogressivement, il les charge de nouvelles valeurs, qui sont celles de 
A metáfora concentrada no inusitado sintagma da "fiel traição" estabelece, portanto, a ponte entre a margem da visão negativa e a margem da concepção valorativa. No desequilíbrio que agora privilegia um africano e sua forma particular de aliar as suas marcas identitárias, Gassama entrevê ainda a via da verdadeira francofonia: a francofonia do futuro ${ }^{42}$, aquela que não será baseada nem na caridade, nem na mendicância, mas no diálogo livre e fraterno entre duas civilizações, entre a língua francesa e as línguas negroafricanas $^{43}$. E diálogo livre e fraterno compreende troca e, naturalmente, concessões.

\section{Povo e cultura Malinké}

O povo Malinké, grande grupo da região du Mandingue, no oeste da África, ocupa um vasto território que compreende o sudoeste do Mali, o sul do Senegal, o leste da Guiné, o Burkina Faso e o noroeste da Costa do Marfim (cf. Anexo 3). Grandes guerreiros cujas conquistas se estenderam da Idade Média ao início do período colonial, são também conhecidos como importantes comerciantes do oeste africano.

O período que abrange o surgimento e o apogeu do Império do Mali ou Império Mandigue medieval ${ }^{44}$, o mais poderoso dos impérios medievais da África ocidental, se estende do século XIII ao século XV. Em 1230, inicia-se a

son terroir, qui font parfois briller les mots comme des pépites d'or. (GASSAMA, Makhily, op. cit., p. 25).

42 Grifo do autor.

43 ... la voie à la vrai francophonie, à la francophonie de demain, celle qui ne sera fondée ni sur la charité ni sur la mendicité, mais sur le dialogue libre et fraternel entre deux civilisations, entre la langue française et les langues négro-africaines. (GASSAMA, Makhily, 1995, idem, p. 13).

44 Mali significa "onde vive o rei", Malinkés ou Mandingues designam os homens ou os sujeitos do Mali. In: GARINE, Igor. Mali. In : BALANDIER, Georges et MAQUET, Jacques (Dir.). Dictionnaire des civilisations africaines. Paris: Fernand Hazan, 1968. p. 258. 
formação do Estado mandingue, quando Soundjata Keita ${ }^{45}$, considerado pelos africanos do oeste e, principalmente, pelo povo Mandingue, o maior imperador do Mali, consegue subtrair seu país à dominação $\operatorname{sosso}^{46}$. É graças ao poderio militar e à excelência administrativa instaurados sob as ordens de Soundjata que 0 Império Mandingue consegue expandir suas fronteiras ${ }^{47}$, expansão também empreendida por seus sucessores até o reinado de Kankan-Moussa (ou Kankoum Moussa), considerado por árabes e europeus o mais célebre dentre os chefes deste Império ${ }^{48}$.

No século $X V$, inicia-se o período de decadência do Império Mali; em 1485 , ele perde suas províncias orientais e, no século XVI, as ocidentais são conquistadas pelos Mossi. A dissolução de um império abre então espaço para a fundação dos reinos Bambara, vindos do leste no século XVII. Foi com a chegada de dois irmãos - que teriam conseguido atravessar o rio Niger montados sobre um enorme peixe - que os reinos bambara se instalaram sobre as ruínas do Império medieval do Mali. Baramangolo, teria permanecido no local, criando o reino de Segou, enquanto, Niangolo, dirigindo-se ao oeste, seria o responsável pela fundação da dinastia dos chefes Kaarta. Segundo Denise Paulme, a organização sistemática e centralizada da sociedade bambara foi rara e temporária: o termo 'império' não traduz nada além da atração exercida por uma família, em razão de seu prestígio, sobre grupos que aceitaram a suserania. ${ }^{49}$

45 Soundjata foi o herói cujos feitos e bravura constituíram importante material das narrativas tradicionais e do romance histórico africano, dentre os quais destaca-se a obra de Djibril Tamsir Niane, Soundjata ou l'épopée du mandingue.

${ }^{46}$ O Mali era, no início do século XIII, uma província de poucas proporções submetida ao domínio do reino de Sosso.

47 Joseph Ki-Zerbo (2003, p. 41) não deixa de observar, em A quand I'Afrique?, o caráter nômade e conquistador do povo africano.

48 Segundo Camara Sory (1992, p. 19), devido à legendária peregrinação feita à Meca em 1324, ou 1335 (CISSÉ, 1992, p. 15), durante a qual fez-se acompanhar de enorme séqüito e distribuiu grande quantidade de ouro no Egito, chegando a provocar a queda do preço do metal durante vários anos.

49 ... le terme $d^{\prime}$ «empire » ne traduit guère plus que l'attraction exercée par une famille en raison de son prestige sur des groupes qui acceptèrent sa suzeraineté. (PAULME, Denise. Bambara. In : BALANDIER, Georges et MAQUET, 
Foi somente no século XIX que o almany ${ }^{50}$ Samory Touré fundou um reino muçulmano, retomando o espírito malinké de conquista e expansão. Samory Touré ampliou consideravelmente o domínio malinké e foi um dos maiores obstáculos para a conquista colonial da África do oeste:

Do ponto de vista político, três chefes, temíveis pela extensão de seus territórios, bem como pela quantidade de seus guerreiros, dominavam o Sudão francês ao norte, a leste e a sudoeste. Sozinhos, sempre podiam, com sua hostilidade, atacar e interditar nossas instalações recém construídas, interditando qualquer comércio exterior; reunidos, eles as teriam lançado em um desastre tamanho que talvez nunca mais tivéssemos tentado trazer a influência e o comércio francês a essas paragens. ${ }^{51}$

Um desses temíveis reis foi o almany Samory que, ao cabo de cinco anos de resistência contra os europeus, ligou-se temporariamente aos franceses por meio de um tratado; Samory, no entanto, quebra seu compromisso e resiste à penetração das tropas francesas no oeste africano até o início do século XX.

Do ponto de vista social e cultural, o império do Mali foi profundamente marcado pela influência islâmica, promovendo a conversão de vários povos mandingues. Desde o século XIII, os soberanos contavam com a colaboração de pregadores, jurisconsultos de ascendência árabe e eram aconselhados por marabus; entretanto, tal influência não se sobrepôs à cultura local e, na prática, o amplo código religioso, moral e político do Alcorão precisou adaptar-

Jacques (Dir.). Dictionnaire des civilisations africaines. Paris: Fernand Hazan, 1968. p. 59).

${ }^{50}$ Termo malinké que significa simultaneamente chefe político e espiritual.

${ }^{51}$ Capitão Péroz em relato das campanhas militares do Sudão em 1887: Au point de vue politique, trois chefs redoutables par l'étendue de leurs territoires, ainsi que par le nombre de leurs guerriers, englobaient le Soudan français au nord, à l'est et au sudouest. Seuls, ils pouvaient par leur hostilité battre toujours en brèche et arrêter notre établissement naissant et, en tout cas, lui interdire tout commerce extérieur ; réunis, ils l'eussent fait sombrer dans un désastre tel que jamais peut-être nous n'eussions plus tenté de porter l'influence et le commerce français dans ces parages. (PEROZ apud CAMARA, Sory. In : Gens de la parole: Essai sur la condition et le rôle des griots dans la société malinké. Paris: ACCT; Paris: Karthala; Conakry: SAEC, 1992. p. 21). 
se à cultura e às crenças locais, realizando o que hoje conhecemos como processo de transculturação ${ }^{52}$, que, a exemplo da "cópula genética dos indivíduos" forma uma nova composição cultural na qual distingue-se facilmente os traços dos elementos que o formaram. Esta composição permanece ainda hoje como um dos traços característicos de alguns grupos, dentre os quais os malinkés, que, embora muçulmanos, mantêm a tradição local.

\section{Da cheferia tradicional à administração colonial}

Com o objetivo de preservar a memória tradicional e o patrimônio cultural da Costa do Marfim, o Instituto de Etno-sociologia da Universidade de Abidjan lançou, em 1988, uma coleção que pretendia reunir os textos dos principais pesquisadores, professores, membros das administrações e demais pessoas que pudessem, pelo testemunho de suas experiências com a tradição, a história, os costumes e as crenças, contribuir para a "defesa e ilustração" das culturas e grupos sociais da Costa do Marfim. Dentro deste projeto, encontramos, como primeira publicação, a reprodução do livro de FrançoisJoseph Amon d'Aby, Le problème des chefferies en Côte d'Ivoire, publicado em 1958 e que entrou, rapidamente, na categoria de documentos esgotados. O livro divide-se em duas partes: a primeira descreve o funcionamento das cheferias tradicionais do grupo Akan; a segunda, a evolução da cheferia durante o período colonial.

Interessa-nos aqui, sobretudo, a segunda parte, em razão da relevância das intervenções da civilização ocidental nos regimes das sociedades tribais na África, em geral, e na Costa do Marfim, em particular. Resumimos a seguir as

52 Noção elaborada por Fernando Ortiz no ensaio Do fenômeno social da "transculturação" e de sua importância em Cuba. Tradução: Lívia Reis. In: Contrapunteo cubano del tabaco y del azúcar.. La Habana: Editorial de Ciencias Sociales, 1983. (1. ed.: 1940). 
principais implicações recenseadas e analisadas por Amon d'Aby a esse respeito.

Com sua chegada em missão colonizadora na região oeste da África, os europeus não tardaram a inferir o poder da organização político-religiosa concentrado na figura dos chefes autóctones e, conseqüentemente, a necessidade de fechar acordos que pudessem garantir, de modo eficiente, a soberania européia sobre as regiões ocupadas, a livre circulação e o tráfico de produtos. O meio encontrado pelos franceses para seduzir e engajar os negros nos acordos e tratados foi o pagamento regular de soldos, cujo valor, calculado em moeda européia, era pago com produtos como fuzils, pólvora, tabaco e álcool.

Inicialmente, os chefes autóctones respeitaram escrupulosamente os compromissos estabelecidos pelos tratados, ignorando as reais intenções dos europeus, "considerando-os seus "brancos", ou seja, homens que vieram especialmente para eles, decididos a permanecer ao lado deles para promover a força e a prosperidade de suas regiões". Foi sob esta óptica ingênua que vários autóctones tornaram-se intermediários entre os produtores internos e consumidores estrangeiros, captando grandes benefícios advindos desta função. Mas a ruptura das relações diplomáticas não tardaria a surgir. Depois de ter conquistado a confiança dos chefes eminentes, os europeus empreendem a conquista do interior das regiões e provocam o conflito e as guerras motivadas pelo instinto de independência dos chefes tribais.

Com o fim das relações diplomáticas, a França põe em prática uma política que visa enfraquecer a autoridade dos chefes tradicionais e substituí-la pela administração colonial. Assim, os tronos foram destruídos e os chefes recalcitrantes ou indesejáveis afastados e, freqüentemente, substituídos por antigos auxiliares: intérpretes, guardas de circunscrição, etc... (AMON D'ABY, 1988 , p. 27) No entanto, essa política de substituição não demorou a revelar sua inconsistência e a necessidade de compor com as autoridades locais tornou-se uma evidência para a política colonial, como podemos notar na declaração do general Carde: 
A colaboração dos chefes se impõe a nós como um dever e uma necessidade... É por meio da íntima associação de todos os elementos de autoridade dispersos em todo o país, é por meio de uma interpenetração continua dos métodos, das mentalidades e dos interesses que, com maior segurança, conseguiremos conduzir a um futuro mais digno os povos que se submeteram a nossa tutela. $O$ comando autóctone deve tornar-se o mais sólido ponto de apoio da alavanca com a qual nos propomos a instruir a massa. ${ }^{53}$

Em que pese a falácia do discurso, a colaboração foi de fato incorporada aos métodos de instauração da administração colonial, a qual definiu com precisão sua doutrina política, fixou regras e definiu o status e raio de ação dos chefes, além de assentar as bases de organização do comando autóctone e seu papel dentro do quadro geral de administração direta. Como observa Diandue B. K. Parfait,

Uma das ilustrações históricas do expansionismo francês no Sudão foi a instalação francesa na África subsaariana, durante a qual Gallieni e Ahmadou assinaram, em 1880, um tratado sobre a liberdade de comércio, atribuindo uma alta prioridade aos franceses. [...] Em suma, após a divisão da África, a França metropolitana se precipitou sobre o Manding a fim de domesticá-lo. Sob a dominação dos generais de guerra, dentre os quais Gallieni e Faidherbe, as Colunas francesas conquistarão progressiva e penosamente os povos refratários e hostis à sua instalação. ${ }^{54}$

${ }^{53}$ La collaboration des chefs s'impose à nous comme un devoir et une nécessité... C'est par l'intime association de tous les éléments d'autorité épars dans le pays, c'est par une interpénétration continue des méthodes, des mentalités, des intérêts que nous parviendrons plus sûrement à guider vers des destinées plus hautes, les peuples qui se sont confiés à notre tutelle. Le commandement indigène doit être le plus solide point d'appui du levier avec lequel nous nous proposons d'élever la masse. (CARDE apud AMON d'ABY. In : AMON D'ABY, François-Joseph. Le problème des chefferies en Côte d'Ivoire. Abidjan : NEA, 1988. p. 29).

${ }^{54}$ L'une des illustrations historiques de l'expansionnisme français dans le Soudan est I'installation française en Afrique subsaharienne au cours de laquelle Gallieni et Ahmadou signent en 1880 un traité sur la liberté du commerce avec une priorité accrue pour les Français. (...) En substance, après le partage de l'Afrique, la France métropolitaine s'est ruée sur le Manding pour le dompter. Sous la férule des généraux de guerre, dont Gallieni et Faidherbe, les Colonnes françaises conquerront progressivement et difficilement des peuples réfractaires et hostiles à leur installation. (PARFAIT, Diandue Bi Kacou, 2003, op. cit., não paginado). 
Embora Amon d'Aby tenha enfatizado a profunda mudança social ocorrida após o advento da colonização, seu estudo limita-se à constatação da substituição da cheferia tradicional e hereditária pela cheferia administrativa deste período, não considerando, portanto, o problema dessa instituição política e cultural após a independência. A questão que se impôs imediatamente após a conquista da liberdade política com relação às cheferias baseava-se, sobretudo, na decisão que se impunha pelas injunções do desenvolvimento: mantê-las ou suprimi-las? No caso da primeira opção, restava saber como fazê-lo sem que os problemas do meio rural se interpusessem no caminho de uma evolução cada vez mais acelerada. Mariatou Koné e N'Guessan Kouamé, do Instituto de Etno-sociologia da Universidade de Cocody, Abidjan, analisam este impasse da seguinte maneira:

Se o poder tradicional exercido em uma aldeia ou mesmo em um distrito não representa uma verdadeira ameaça para o poder do Estado, o mesmo não ocorre quando se trata de uma autoridade que tem grande ascendência sobre uma fração importante da população e do território nacional. A real politik guiou a escolha das autoridades marfinenses no sentido da manutenção da cheferia que devia continuar a desempenhar o papel de auxiliar da administração, mas ser despojada de um poder efetivo. Com o passar dos anos, a cheferia tinha se tornado a sobrevivência de uma instituição que tinha se tornado, a partir de então, o apêndice do poder político central e dos poderes descentralizados dos sous-préfets, préfets e maires. ${ }^{55}$

Um dado importante a ser observado foi a solução encontrada pelo Estado, algum tempo depois, a fim de minimizar a complexidade do problema da gestão das microestruturas organizacionais pré-existentes, as sociedades

${ }^{55}$ Si le pouvoir traditionnel au niveau d'un village ou même d'un canton ne représente pas une vraie menace pour le pouvoir d'Etat, il n'en est plus de même quand il s'agit d'une autorité qui a une emprise sur une fraction importante de la population et du territoire national. La real politk a guidé le choix des autorités ivoiriennes dans le maintien de la chefferie qui devait continuer à jouer le rôle d'auxiliaire de l'administration, mais dépouillée d'un pouvoir réel. Au fil des années, la chefferie était devenue la survivance d'une institution qui était désormais l'appendice du pouvoir politique central et des pouvoirs décentralisés que sont ceux des sous-préfets, préfets et maires. (KONÉ, Mariatou et KOUAMÉ, N'Guessan. Chefferie en mutation en Côte d'Ivoire. In: DÉBATS : Courrier de l'Afrique de I'Ouest. Abidjan : CERAP/ Inades, n. 21, jan. 2005. p. 16). 
com estrutura monárquica e que repousavam, em sua maioria, no exercício do poder hereditário: a intelectualização e a modernização dos poderes tradicionais. Além das implicações políticas, sociais e culturais que soem decorrer desse tipo de decisão, a substituição dos antigos chefes analfabetos por intelectuais e universitários inaugurou um fenômeno que aponta para a formação da sociedade pós-Panóptica (Bauman, 2001, p. 18), ou seja, a sociedade na qual as operações de poder, realizadas à distância, protegem as personalidades tutelares, facilitando-Ihes a fuga e a inacessibilidade. A maneira pela qual essa gestão à distância seria efetivada encontrou na delegação de poder o meio mais eficaz: o intelectual ativo permanece na cidade, enquanto seu adjunto, de posse de uma procuração, administra in loco a aldeia.

Em Les soleils des Indépendances, as modificações operadas no sistema tradicional das cheferias formam a origem dos males de Fama. Dentro da cronologia interna do romance, o enfoque repousa primeiramente na condição de espoliado do personagem: o príncipe quase mendigo (KOUROUMA, LsdI, p. 13), subtraído de seus bens e de seu poder como chefe Doumbouya - o jàmúr outrora usado para homenagear ou glorificar uma figura eminente dentro da estrutura social tradicional que, sob a óptica de Kourouma, se torna desprovido de sentido honorífico e transforma-se em motivo de desdém e sarcasmo. É apenas na segunda parte do romance, com a morte de Lacina, que encontramos a referência direta à primeira ruptura na organização da cheferia tradicional promovida pelos franceses, durante a colonização, por meio de tratados de protetorado que garantiram a completa soberania sobre as regiões protegidas:

[Lacina] I'homme qui par ses intrigues, maraboutages, sacrifices avait évincé Fama de la chefferie du Horodougou $(. . .)^{57}$

\footnotetext{
${ }^{56}$ Nome do clã usado para identificar o indivíduo e o grupo; também empregado como marca de distinção. Cf. CAMARA, Sory. La société clanique. In : Gens de la parole: Essai sur la condition et le rôle des griots dans la société malinké. Paris: ACCT; Paris: Karthala; Conakry: SAEC, 1992. p 29-34.

57 KOUROUMA, LsdI, p. 81.
} 
Dentro da perspectiva tradicional, Lacina recorre à feitiçaria e aos sacrifícios para conseguir a cheferia do Horodougou; essa é a visão de mundo de Fama, mas a alusão às intrigas pode aqui ser considerada sob dois ângulos distintos: as artimanhas empregadas para compor com a administração colonial no momento em que os chefes recalcitrantes foram afastados ou substituídos por aqueles que aceitaram a tutela européia; ou ainda, um procedimento que sempre fez parte das conquistas dos grandes heróis da tradição e que não chegava a constituir uma ação negativa, mas um artifício que conduzia mais celeremente ao objetivo e garantia a vitória. A intriga e a mentira podiam ser consideradas como virtudes quando praticadas por eminentes figuras da tradição com o propósito de resgatar a honra ou vingar uma espoliação. Esta segunda acepção do termo teria sido, sem dúvida, aplicada ao próprio Fama, caso ele tivesse conseguido se manter na cheferia do Horodougou. Suas intrigas e composição talvez tivessem ocorrido, naquela ocasião, com outros chefes, ou com pessoas da estirpe do pai de Diakité, condenado à morte por ter enfrentado e assassinado o secretário geral e membros do partido único (KOUROUMA, LsdI, p. 84-85). Essa especulação de nossa parte fundamenta-se no caráter ambíguo do protagonista do romance, pois ao lado das lutas anti-colonialistas e da oposição à política pósindependência, Fama deixa claro seu arrependimento em relação à resistência ao regime colonial ou, ao menos, sua maleabilidade em mudar de margem, com a condição de obter os benefícios que acredita serem seus por direito:

Que n'a-t-il pas fait pour être coopté ? Prier Allah nuit et jour, tuer des sacrifices de toutes sortes, même un chat noir dans un puits $(. . .)^{58}$

Pusilanimidade ou dissimulação malinké? Assim como os Malinkés "rezam" sobre dois altares ${ }^{59}$, Fama aceitaria de bom grado um bom cargo de

\footnotetext{
${ }^{58}$ KOUROUMA, LsdI, op. cit., p. 25.

${ }^{59}$ A falsidade é atribuída por Fama ao povo malinké que, segundo ele, hesita entre o respeito ao Alcorão e a crença no Koma. Em Togobala, aux yeux de tout le monde, tout le monde se dit et respire musulman, seul chacun craint le fetiche. (KOUROUMA, idem, p. 105).
} 
comando da era das independências. Mas diante da frustração, a morte de Lancina também se apresenta como a ocasião aparentemente ideal para a reabilitação das cheferias:

Les Indépendances avaient supprimé la chefferie, détrôné le cousin de Fama, constitué au village un comité avec un président. Un sacrilège, une honte. Togobala était la chose des Doumbouya. ${ }^{60}$

Mas o problema é justamente a consciência da desvalorização e da inutilidade do empreendimento:

... Malheureusement, Togobala, les Doumbouya et même le Horodougou ne vallaient pas en Afrique un grain dans un sac de fonios. ${ }^{61}$

Para a aristocracia autóctone arruinada pelo colonialismo, a passagem à independência representou a oportunidade de retomar a supremacia política e recuperar suas bases econômicas. Mas a nova estrutura política e administrativa não comportava mais o retorno a uma gestão tradicional, inadaptada ao estado em vias de modernização. Quanto à economia, as ambições da nova política também não toleravam as práticas empíricas tradicionais, nas quais prevalecia a improvisação que era, em tese, contrária ao espírito moderno de racionalidade e, sobretudo, de previsão. Deste modo, a sociedade das Independências não pode mais atender às expectativas da antiga classe dirigente que, com a chegada do Estado moderno, passou rapidamente do privilégio à marginalização. Christophe Wondji resume o contexto histórico vivido pela antiga classe dirigente marginalizada pelas Independências:

Alguns de seus elementos são rejeitados porque se fixam aos rígidos valores ancestrais de honra e de dignidade incompatíveis com o novo código ideológico baseado na busca do lucro e do compromisso. 0

\footnotetext{
${ }^{60}$ KOUROUMA, LsdI, op. cit., p. 113.

${ }^{61}$ KOUROUMA, idem, p. 113.
} 
resultado disso é um profundo ressentimento. $A$ colonização e a independência foram fatais para essa aristocracia que lutou contra a colonização e a favor da Independência. Ela vitupera contra a ingratidão dos antigos amigos e contra a ingratidão dos tempos. Só Ihe resta deixar-se dissolver no tórrido turbilhão desses novos "Sóis", desses "hard times" africanos. ${ }^{62}$

A marginalização progressiva foi, portanto, a parte que coube a essa aristocracia, ultrapassada e condenada, e sua proscrição, mais do que uma reação a uma ideologia reacionária de retorno ao passado, representa as dificuldades enfrentadas pelas sociedades africanas nesse período de mutação política, econômica e cultural.

\section{Les soleils des indépendances: apresentação e resumo}

Escrito entre 1963 e 1965, no momento em que os países africanos de língua francesa começam a dar seus primeiros passos como nações independentes, Les Soleils des Indépendances encontra-se, do ponto de vista temático, no vórtice das transformações decorrentes da colonização e da desilusão das independências. No romance, Kourouma relata a derrocada da estrutura feudal africana engendrada, em primeiro lugar, pela colonização e, em seguida, pelos processos de independência das nações. Fama Doumbouya, príncipe do Horodougou, tendo perdido seu direito à cheferia de Togobala, é reduzido à mendicância como meio de sobrevivência na capital. O autor coloca em cena um personagem que se vê espoliado de seu título, de seus valores

${ }^{62}$ Certains de leurs éléments sont rejetés parce qu'ils s'attachent aux droites valeurs ancestrales d'honneur et de dignité incompatibles avec le nouveau code idéologique fondé sur la recherche de l'intérêt et du compromis. Il en résulte un profond ressentiment. La colonisation comme l'indépendance ont été fatales à cette aristocratie qui a lutté contre la colonisation et pour l'Indépendance. Elle vitupère contre l'ingratitude des anciens amis et contre l'ingratitude des temps. Il ne lui reste plus qu'à se laisser dissoudre dans le chaud tourbillon de ces nouveaux «Soleils », de ces "hard times» africains. (WONDJI, Christophe. "Le contexte historique". In: M'LANHORO, Joseph. (org.) Essai sur Les soleils des indépendances. Abidjan: NEA, [1974]. p. 24). 
tradicionais, de seus bens e de sua dignidade. A trajetória de Fama, fracassado econômica e socialmente e com total inadaptação aos novos valores impostos pela colonização, alude, sem dúvida, ao universo extradiegético da profunda decepção do autor com as independências africanas.

Ao criar o país fictício da Côte des Ébènes, fica evidente a referência à Costa do Marfim, mas ao escolher como título da obra Les soleils des Indépendances, o plural também alude ao processo global de independência dos países até então sob o domínio da colonização francesa, evocando por inferência o problema da identidade dos indivíduos e povos africanos, que divergem pelo estatuto das nacionalidades, mas se reconhecem pela afinidade da herança da tradição.

A extensão semântica do título do romance, como sugere Madeleine Borgomano (1998), refere-se ao suposto equívoco que poderia ser gerado para o leitor não malinké, não fosse o pronto esclarecimento do autor sobre o caráter obscuro deste título, reconhecendo, de antemão, que seu público leitor não é majoritariamente africano e que, mesmo para estes, o traço enigmático permanece. ${ }^{63}$

De fato, a história narrada ultrapassa os limites da experiência individual: o fracasso de Fama equipara-se ao malogro de todo o oeste africano. Como indivíduo acuado pela instituição do Estado-nação ${ }^{64}$, que perdeu o vínculo com a única comunidade de pertença que reconhecia até então como legítima e não encontra sentido no novo sistema de atribuição de identidade, Fama pode perfeitamente representar, no plano individual, não

${ }^{63}$ Essa é a razão pela qual as explicações são dirigidas aos leitores não malinkés, de modo geral: l'ère des Indépendances (les soleils des Indépendances, disent les Malinkés)... (KOUROUMA, LsdI, op. cit., p. 9). Às explicações relativas ao título do romance, seguem-se outras que visam igualmente a elucidação de dados culturais do povo malinké. Por exemplo, a representação semântica do sangue durante os rituais funerários de Lacina: Mais le sang, vous ne savez pas parce que vous n'êtes pas Malinké, le sang est prodigieux, criard et énivrant. (KOUROUMA, idem, p. 141).

${ }^{64}$ Refiro-me à duas passagens pontuais nas quais o fato de não possuir uma carteira de identidade impede Fama de atravessar a fronteira que separa a Côte des Ébènes da República socialista do Nikinai, ambos ocupando terras do Horogoudou que pertenceram, outrora, aos Doumbouya. (KOUROUMA, idem, p. 101;189). 
apenas a trajetória de um nobre malinké destituído de suas devidas prerrogativas, mas também simbolizar o destino de muitos homens que não entenderam ou mostraram-se refratários às injunções da colonização, que passaram a associar a noção de identidade à natividade em detrimento da noção de afinidade com uma comunidade cultural.

O romance é dividido em três partes, cada uma delas contendo, consecutivamente, quatro, cinco e dois capítulos. Tal disposição, além se ser um recurso recorrente no romance africano, assemelha-se aos quadros da narrativa tradicional, como veremos mais adiante, os quais, dispondo de relativa autonomia com relação à unidade narrativa, eram justapostos de modo a formar a coerência do texto.

Na primeira parte, a narrativa se inicia com a cerimônia dos funerais de Ibrahima Koné, realizada na capital da Côte des Ébènes; nesta passagem, o narrador descreve a grotesca participação de Fama Doumbouya! Vrai Doumbouya, père Doumbouya, mère Doumbouya, dernier et légitime descendant des princes Doumbouya du Horodougou (KOUROUMA, LsdI, p.11), agora reduzido à imagem de vautour, atributo pejorativo com o qual os Malinkés classificam os griots e anciãos que andam de funeral em funeral para sobreviver daquilo que é distribuído entre os participantes. O atraso na chegada de Fama é o ponto de partida para as injúrias e humilhações lançadas pelo griot sobre Fama, um exemplo dos descendants de grandes familles guerrières qui se prostituaient dans la mendicité, la querelle et le déshonneur (KOUROUMA, LsdI, p. 17-18).

Durante a execução de suas preces na mesquita, o exercício da memória resgata a saudade da infância no Horodougou, seu passado como comerciante, a exclusão da cheferia de Togobala, sua luta anticolonialista e a decepção com as independências. Um fluxo intermitente de imagens que evocam tanto o passado longínquo quanto o passado recente. A imagem de sua esposa Salimata surge na alternância entre a femme sans limite dans la bonté du coeur, les douceurs des nuits et des caresses (KOUROUMA, LsdI, p. 28) e as longas trépidations et convulsions (KOUROUMA, LsdI, p. 29) dos rituais 
indicados por feiticeiros e marabus a fim de reverter a esterilidade e fecundar o ventre.

E a segunda metade da primeira parte do romance é inteiramente dedicada à Salimata. Após uma noite mal dormida, Salimata mergulha na vida laboriosa que representa o quotidiano da grande maioria de mulheres africanas; como observa Aminata Traoré (1987, p. 106), Les soleils des Indépendances foi o primeiro romance africano que, além das dores físicas e psíquicas sofridas pelas mulheres, levou em conta a penosa rotina à qual estão submetidas. A narração minuciosa dos afazeres quotidianos realizados entre a casa, o mercado da cidade branca e o mercado do bairro negro, é entrecortada pela retrospectiva dos fatos que marcaram a vida psíquica de Salimata: as imagens da excisão, do estupro cometido pelo feiticeiro Tiécoura, e seus dois casamentos estéreis, primeiro com Baffi e depois, Tiémoko. Já na capital, sua vida não é menos marcada por traumas e experiências desconcertantes. Atormentada com a impossibilidade de gerar um filho, Salimata tem uma gravidez psicológica que aumenta sua vergonha de mulher estéril. No mercado, a bondade que julga indispensável para atrair a compaixão de Allah, leva Salimata a distribuir gratuitamente um prato de comida a cada desempregado e faminto do mercado; mas ela é atacada e despojada de seus pertences e de sua honra:

Elle avait les colliers et boucles d'oreille arrachés, les plats ébréchés. Tout son argent, tout son gain emporté! Des mains s'étaient promenées dans ses entre-fesses et entre-jambes, sous les seins et le bas-ventre. ${ }^{65}$

Salimata retorna ao bairro negro e consulta Abdoulaye, o marabu que poderia desviar a má sorte e ordenar os sacrifícios necessários à fecundação. Mas Abdoulaye, tomado pela beleza e pelo desejo de seduzir Salimata tenta

65 KOUROUMA, LsdI, op. cit., p. 62. 
possuí-la à força, provocando a ira de Salimata que o ataca com uma faca semelhante ao instrumento usado no campo de excisão ${ }^{66}$.

A segunda parte do romance concentra os episódios da morte e dos funerais do primo Lacina, I'homme qui par ses intrigues, maraboutages, sacrifices avait évincé Fama de la chefferie du Horodougou (KOUROUMA, LsdI, p. 81). O deslocamento é também a oportunidade para Fama de rever Togobala e retomar o com o que restou do Horogoudou. Assim como Fama foi destituído da cheferia, a Togobala coube o papel da frágil representação da tradição frente aos arroubos da modernidade. Do "grande acampamento" (Togobala) construído por Souleymane e seus talibês (p. 98), resta a imagem da degradação:

Du Togobala de son enfance, du Togobala qu'il avait dans le coeur il ne restait même plus la dernière pestilence du dernier pet. En vingt ans le monde ne s'était pourtant pas renversé. Et voilà ce qui existait. De loin en loin une ou deux cases penchées vieillottes, cuites par le soleil, isolées comme des termites dans une plaine. ${ }^{67}$

A imagem da ruína de Togobala, em sua dupla acepção de desmoronamento material e de destruição moral e social, simboliza, sem dúvida, a morte da tradição, mas em meio à ambigüidade dos momentos de transição, no "entrecruzamento de tempos heterogêneos" surgem essas ruínas, que balbuciam uma mensagem quase inaudível sobre a sua significação. "Ruínas: ruído e lembrança. Em meio ao desaparecimento, são guardiãs do imperecível. São vestígios do invisível" (MATOS, 1998, p. 84). O invisível, a energia sutil, o mundo imaterial da tradição que nenhum golpe de canhão ou força bruta consegue apagar.

\footnotetext{
${ }^{66}$ As meninas em idade de passar pelo ritual da excisão são levadas para um espaço determinado que varia segundo as etnias. Ela pode ser praticada em uma cabana retirada ou na floresta sagrada. No caso de Salimata, a semelhança da faca utilizada para atacar Abdoulaye com o instrumento da intervenção remonta ao trauma por ela sofrido durante o rito de ablação. Cf. DEMBÉLÉ, Salimata Kéïta. Excision, Douleur de Femme: Pour une stratégie de communication en faveur de la lutte contre l'excision en Côte d'Ivoire. Abidjan: EDILIS, 2001, p. 32-34.

67 KOUROUMA, LsdI, op. cit., p. 103.
} 
Inicialmente motivado pelo dever de participar dos funerais e pelo desejo de reabilitar a cheferia após a morte de Lacina (um dos poucos momentos de prospecção do romance), Fama empreende a longa viagem da capital ao Horodougou. Durante a viagem, Fama ouve o relato das experiências que Diakité, Konaté e Sery tiveram com as alterações políticas das independências. Chegando a Bindia, cidade natal de Salimata, Fama é acolhido, honrado e reverenciado como um Presidente da República, do partido único ou do governo, ou como um verdadeiro malinké, marido de Salimata (KOUROUMA, LsdI, p. 95). A viagem continua no dia seguinte e, na fronteira que separa a Côte des Ébènes da República do Nikinai, Fama é confrontado, pela primeira vez, com a exigência da carteira de identidade. Sua chegada a Togobala é marcada pela decepção com o estado de decadência da antiga capital de todo o Horodougou. Fama recebe as homenagens das famílias e toma conhecimento dos meios que conservaram Diamourou, griot dos Doumbouya em meio à miséria de Togobala: foi graças a sua filha Matali, concubina de um comandante branco, e aos seus dois netos que Diamourou pôde manter a saúde e a serenidade. Quanto a Balla, o velho feiticeiro e escravo liberto, tornou-se o mais rico e o mais temido porque na impossibilidade de ser socorrido por Allah, um Malinké sempre recorre aos fetiches de Balla e, independente dos resultados, os serviços sempre são pagos. Diamourou e Balla oferecem apoio e dinheiro a Fama para que ele possa reabilitar a cheferia, mas Fama não parece muito entusiasmado frente ao recenseamento desolador de sua herança:

Fama regardait la concession et ne se rassasiait pas de la contempler, de l'estimer. Comme héritage, rien de pulpeux, rien de lourd, rien de gras. Même une poule épatée pourrait faire le tour du tout. Huit cases debout, debout seulement, avec des murs fendillés du toit au sol, le chaume noir et vieux de cinq ans. Beaucoup à pétrir et à couvrir avant le gros de I'hivernage. L'étable d'en face vide; grande case commune, où étaient mis à l'attache les chevaux, ne se souvenait même pas de l'odeur du pissat. Entre les deux, la petite case des cabrins qui contenait pour tout et tout: trois bouquetins, deux chèvres et un chevreau faméliques et puants destinés à être égorgés aux fétiches de Balla. En fait d'humains, peu de bras travailleurs. Quatre hommes dont deux vieillards, neuf femmes dont 
sept vieillottes refusant de mourir. Deux cultivateurs! Jamais deux laboureurs n'ont eu assez de reins pour remplir quatorze mangeurs, hivernage et harmattan! Et les impôts, les cotisations du parti unique et toutes les autres contributions monétaires et bâtardes de l'indépendance, d'où les tirer? En vérité Fama ne tenait pas sur du réel, du solide, du définit... ${ }^{68}$

Enquanto aguardam o quadragésimo dia dos funerais de Lacina, a nostalgia dos velhos tempos encontra uma satisfação provisória nas histórias de caça de Balla. Na visita às viúvas de Lacina, Diamourou insiste no casamento de Fama com Mariam, a bela e enfeitiçante mulher que, apesar do mau gênio, poderia garantir a descendência dos Doumbouya. No entanto, outro foco chamaria a atenção de Fama pela sua importância política e moral: Babou, o presidente do comitê do Partido único, temendo uma reação política em Togobala, viria interrogar Fama. Um palabre foi organizado para a alegria da população local; ao fim de muita discussão, insultos e ameaças, Babou aceita o acordo estabelecido por Diamourou e Balla. Fama permanecerá como chefe habitual e Babou, o presidente oficial.

O capítulo cinco da segunda parte encerra a viagem a Togobala: ao término dos funerais do quadragésimo dia de Lacina, Fama decide retornar à capital, contrariando as expectativas de todos, sobretudo as de Balla que pressentiu os malefícios da viagem e sabia que:

... un Doumbouya descendant de Souleymane ne pousse, ne prospère, ne fleurit et ne fructifie qu'à Togobala. ${ }^{69}$

Na terceira parte do livro, a narrativa é visivelmente mais condensada do que as demais, como observou Borgomano (1998, p. 33).

Ao chegar à capital, Fama apresenta sua segunda esposa, Mariam, a Salimata; mas o breve período de gentilezas que marca a recepção da coesposa é seguido de hostilidades e disputas graves, levando Fama a afastar-se e, novamente, dedicar-se à política. Acusado de participar do complô contra o

\footnotetext{
${ }^{68}$ KOUROUMA, LsdI, op. cit., p. 106-107.

${ }^{69}$ KOUROUMA, idem, p. 147.
} 
presidente, Fama é preso e conduzido ao "campo sem nome" e, depois, a um quartel, onde passaria um longo tempo até que fosse julgado. Interrogado, Fama é condenado a vinte anos de reclusão por ter omitido das autoridades o sonho que teve com Nakou, ministro suspeito de estar à frente do complô. Acreditando que morreria na prisão, Fama é surpreendido pela súbita decisão do presidente de anistiar os presos políticos em razão da pressão internacional e do desejo de preservar a boa imagem de sua gestão. Fama é libertado e indenizado pelos anos de reclusão. Apesar dos esforços de Bakary, seu companheiro das reuniões políticas, para convencê-lo a usufruir os benefícios prometidos pelo presidente a todos os ex-detentos, Fama decide voltar a Togobala.

Était-ce dire que Fama allait à Togobala pour se refaire une vie? Non et non! Aussi paradoxal que cela puisse paraître, Fama partait dans le Horodougou pour y mourir le plus tôt possible. Il était prédit depuis des siècles avant les soleils des Indépendances, que c'était près des tombes des aïeux que Fama devait mourir; et c'était cette destinée qui expliquait pourquoi Fama avait survécu aux tortures des caves de la Présidence, à la vie du camp sans nom; c'était encore cette destinée qui expliquait cette surprenante libération qui le relançait dans un monde auquel il avait cru avoir dit adieu. ${ }^{70}$

Ao chegar à fronteira da República do Nikinai, os viajantes constatam que a passagem está suspensa até segunda ordem. Infringindo as ordens de interdição, Fama rompe o bloqueio e faz a travessia da ponte que separa os dois países. Acuado pela perseguição dos guardas fronteiriços, Fama se joga no rio e é atacado por um crocodilo sagrado que, para ele, não ousaria "atacar o último descendente dos Doumbouya" (p. 191). Fama morre em uma ambulância, a caminho de Togobala, em terras do Horogoudou.

${ }^{70}$ KOUROUMA, LsdI, op. cit., p. 185. 


\section{DA NARRATIVA TRADICIONAL AO ROMANCE DAS INDEPENDÊNCIAS}

Les paroles très anciennes

C'est comme les graines...

Camara Sory

Em Du récit oral au roman, Amadou Koné faz uma análise dos elementos constitutivos da narrativa heróica tradicional com o intuito de delimitar as convergências e divergências existentes entre a narrativa oral e o romance moderno. Seguindo uma ordem cronológica, analisa consecutivamente a narrativa oral tradicional, o romance histórico e o romance moderno, partindo da hipótese de que parte da fiç̧ão negro-africana é decorrente de um processo evolutivo da narrativa heróica tradicional oral e que essa evolução é devida à transformação da realidade africana e de seu sistema de criação literária". ${ }^{71}$

Makouta Mboukou dá uma orientação semelhante a seu estudo sobre o romance africano de língua francesa, sendo que este, menos imparcial do que o de Amadou Koné, não se limita à composição formal da criação literária. Para ele, a literatura negro-africana constitui um vasto conflito de culturas [e] a mestiçagem cultural surge (...) como a vitória da cultura ocidental sobre a cultura negro-africana ${ }^{72}$. Em oposição ao que chamou de duplo equívoco de Léopold Sédar Senghor, constituído, em primeiro lugar, pela crença na mestiçagem cultural como uma via possível de realização da raça negra e, em

71 ... à la transformation de la réalité africaine et de son système de création littéraire. (KONÉ, Amadou. Du récit oral au roman: Etude sur les avatars de la tradition héroïque dans le roman africain. Abidjan: CEDA, 1985. p. 133).

72 ... la littérature negro-africaine est um vaste conflit de cultures. (...) Le métissage culturel apparaît (...) comme la victoire de la culture occidentale sur la culture négroafricaine... (MAKOUTA-MBOUKOU, Jean-Pierre. Introduction à I'étude du roman négro-africain de langue française: Problèmes culturels et littéraires. $2^{\mathrm{e}}$ éd. Abidjan: NEA, 1980. p. 162). 
segundo, na liberdade decorrente dessa resultante híbrida, Makouta Mboukou considera o encontro de culturas que gerou o romance africano de língua francesa como uma via de alienação, o que para ele representa o corolário da seguinte constatação:

A civilização ocidental é essencialmente caracterizada por sua intolerância. Os três elementos que a compõem não deixam entre si nenhum interstício capaz de abrigar os elementos de cultura estrangeira. São estes: a religião cristã, a técnica e o espírito cartesiano. ${ }^{73}$

Para o autor, os três pilares da civilização ocidental encontram-se na base da rejeição da cultura tradicional africana. Enquanto a religião cristã não reconhece a existência de outras práticas e pensamentos religiosos, a técnica ocidental, filha do pensamento discursivo, rejeita a priori a razão negra. Quanto ao pensamento cartesiano, sua fé na capacidade cognitiva da razão elimina a sensibilidade diante dos mistérios da natureza e a comunhão com as forças secretas do universo como meios de aquisição de conhecimento.

O romance africano, a despeito de sua orientação temática ou ideológica, não poderia deixar de refletir a transculturação resultante do encontro da cultura ocidental com a tradição africana que, por sua vez, compreende a cultura árabe. É nesse sentido que faremos a seguir a verificação da permanência dos elementos da narrativa tradicional oral no moderno romance africano, em geral, e no romance Les Soleils des indépendances, em particular. Cumpre, no entanto, esclarecer que por romance moderno compreende-se as obras de fiç̧ão que adquiriram certa autonomia na expressão de sua individualidade, mas ainda mantinham um vínculo com o passado pré-colonial, com a evocação da tradição, seja por meio da temática, do estilo ou da estrutura formal da obra. Portanto, não faremos qualquer menção aos autores que Bernard Margnier classificou, poeticamente,

\footnotetext{
${ }^{73}$ La civilisation occidentale est essentiellement caractérisée par son intolérance. Les trois éléments qui la composent ne laissente entre eux aucun interstice pour loger les éléments de culture étrangère. Ce sont : la religion chrétienne, la technique et l'esprit cartésien. (MAKOUTA-MBOUKOU, 1980. op. cit., p. 162).
} 
como "os viajantes solitários" (1990b, p. 102), autores dos anos 80, dotados de um estilo próprio, mais individual, mas cujos percursos originais não eliminam a sensibilidade em relação à coletividade, embora esta seja considerada sob uma perspectiva mais universal e menos ligada às questões específicas da África ${ }^{74}$. Ao contrário, a evolução da narrativa tradicional ao romance moderno restringir-se-á à produção literária que marca a passagem do oral ao escrito. Quanto às análises referentes à obra Les Soleils des indépendances, nosso foco se dirige ao que Michel Butor chamou de simbolismo de um romance, que compreende as relações entre o conteúdo da narrativa e a realidade em que vivemos e faz com que essas complexas relações de significação determinem o tema tratado. Assim,

... se o romancista procura nos transmitir fielmente sua experiência, se seu realismo é bastante acentuado, se a forma que emprega é suficientemente integradora, ele é necessariamente levado a considerar esses diversos tipos de relações no próprio interior de sua obra. $O$ simbolismo externo do romance tende a se refletir num simbolismo interno, com certas partes desempenhando, com relação ao conjunto, 0 mesmo papel que este desempenha com relação à realidade. ${ }^{75}$

Nesse sentido, tentaremos, a seguir, avaliar as transformações sofridas pela narrativa africana em sua passagem do oral ao escrito, considerando seus aspectos temáticos, formais e míticos, a fim de podermos avaliar a passagem

\footnotetext{
74 Bernard Margnier refere-se à produção literária dos anos 80 de autores que, nascidos no continente africano, elegeram Paris como domicílio e cujas obras parecem aderir a estratégias muito mais individuais do que coletivas. São eles: Yodi Karone, Marie Ndiaye, Catherine N'Diaye, Blaise NDjehoya, Simon Njami, Calixthe Beyala, Thomas Mpoyi-Buatu, Léandre-Alain Baker Barnabé Laye, Bolya Baenga, Caya Makhele, entre outros.

75 ... si le romancier cherche à nous faire part sincèrement de son expérience, si son rélisme est assez poussé, si la forme qu'il emploie est suffisamment intégrante, il est nécessairement amené à faire état de ces divers types de relations à l'intérieur même de son ouuvre. Le symbolisme externe du roman tend à se réfléchir dans un symbolisme interne, certaines parties jouant, par rapport à l'ensemble, le même rôle que celui-ci para rapport à la réalité. (BUTOR, Michel. Essais sur le roman. Paris: Gallimard, 2003. p. 12).
} 
dos valores autênticos da África pré-colonial à concepção de mundo degradado que se reflete na obra Les Soleils des indépendances.

\section{O surgimento da literatura escrita africana de língua francesa}

O romance africano de língua francesa nasceu sob a influência ocidental. A crítica do velho continente foi a primeira a avaliar esse romance, servindo-se para tanto de critérios estéticos ocidentais. No entanto, apontando novos parâmetros de avaliação, a crítica endógena tenta ultrapassar o simples jogo das influências, situando no mesmo patamar a ascendência ocidental e a evolução histórica da África (LEZOU, p. 1977). Embora reconheça a legitimidade dessas fontes, Amadou Koné reivindica o que, a seu ver, constitui a verdadeira paternidade das literaturas africanas em geral e do romance em particular, pois parte da ficção africana escapa à influência européia porque resulta da transformação de uma produção literária que precedeu o encontro com o Ocidente, ou seja, a literatura tradicional. Portanto, a influência européia, a evolução da história recente do continente africano e a herança da narrativa tradicional formam a base sobre a qual se consolidou o romance africano. Se o colonizador trouxe em sua bagagem o cânone ocidental, não pôde aculturar por completo as nações africanas e a produção literária está solidamente ancorada na tradição.

E é porque ela ressuscita esta tradição, opondo-a à civilização imposta do exterior, que o menos significativo de seus escritos é sempre um condensado do conflito de cultura ${ }^{76}$, que é a sua principal característica. (...) Encontramos, em geral, distribuídos nos escritos literários negroafricanos, os elementos tradicionais que permitem reconstituir a tradição negro-africana. ${ }^{77}$

\footnotetext{
${ }^{76}$ Grifo do autor.

77 Et c'est parce qu'elle exhume cette tradition en l'opposant à la civilisation imposée de l'extérieur que le moindre de ses écrits est toujours un condensé du conflit de culture qui est ; a principale de ses caractéristiques. (...) Généralement on a, épars dans les écrits littéraires négro-africains, les éléments traditionnels qui permettent de reconstituer la tradition négro-africaine. (MAKOUTA-MBOUKOU, 1980. op. cit., p. 142).
} 
Ao refletir esse conflito de culturas de modo reivindicativo, engajado ou tolerante com relação à penetração ocidental no continente africano, a produção literária incide, com maior ou menor ênfase, sobre a degradação dos valores tradicionais, apresentando assim a sociedade africana pós-colonial em suas oscilações, contradições, desmantelamentos e sínteses resultantes da hibridização sócio-cultural.

A produção do romance africano de língua francesa é esparsa e lenta até o período da liberação das colônias francesas, em 1960. Makouta MBoukou (1980, p. 195) observa que os primeiros romances representam, na verdade, um período de exploração e experimentação, mas aponta os romances Le reprouvé, do senegalês Massyla Diop, e Karim e Mirages de Paris, do também senegalês Ousmane Socé, como romances dignos de atenção e indicadores dos rumos que tomariam esse gênero na era pós-colonial. Le reprouvé, publicado sob a forma de folhetim, em 1926, já indica a degenerescência dos costumes da África colonial, mas, embora lamente o desaparecimento gradativo do passado africano, não rejeita a assimilação cultural. Quanto a Karim, primeiro romance de Socé, de 1935, o autor define de maneira mais precisa a armadilha montada para o jovem africano letrado, que é seduzido pelo brilho artificial da civilização ocidental, tema, aliás, recorrente na ficção africana.

Se por um lado, intelectuais como Amadou Koné (1985) e Makouta MBoukou (1980) reivindicam o reconhecimento da narrativa oral tradicional como fonte e inspiração da moderna ficção africana, por outro lado, não é possível negligenciar a importância da influência européia, a começar pela questão da mudança de código - do oral ao escrito - e da materialização da literatura, no momento em que a escritura se sobrepõe à memória viva dos documentos "sonoros" que são os griots (NIANE, 1960, p. 6). 


\subsection{Implantação da cultura letrada}

A alteração de código deveu-se à implantação do sistema educacional e conseqüente divulgação da língua e cultura francesas nas antigas colônias. Como propósito inicial, esse sistema previa a formação de modelo europeu para fins de divulgação dos hábitos e da superioridade da civilização ocidental em contraposição ao que o colonizador julgava ser os costumes bárbaros de um povo pouco afeito ao exercício da lógica, o que justificava a precariedade que, na opinião do colonizador, se refletia no cotidiano africano. Entretanto, nos interstícios da ação benevolente, escondia-se a necessidade de fornecer os subsídios adequados à população autóctone para que pudesse colaborar efetivamente com o assentamento da administração colonial. Foi, no entanto, essa ação educativa que proporcionou a formação de leitores e forneceu as bases para o surgimento dos futuros escritores, poetas e, posteriormente, do pensamento crítico africano.

Na verdade, o poder colonial francês, ao organizar um sistema de ensino nos territórios ocupados em função da necessidade de sua própria sobrevivência, suscitou, sucessivamente, e entre outros, dois fenômenos que certamente não figuravam em suas previsões: em primeiro lugar, a formação progressiva de um público que lia e se expressava em francês e, em seguida, a emergência de uma literatura de expressão igualmente francesa. $^{78}$

Embora Gnaoulé-Oupoh se refira aqui à ocupação francesa, este fenômeno pode ser estendido aos demais países africanos de língua inglesa e portuguesa, uma vez que a literatura escrita africana surge desse encontro entre culturas que foi promovido pelo sistema colonial.

\footnotetext{
${ }^{78}$ En effet, le pouvoir colonial français, en organisant, pour les besoins de sa propre survie, un systhème d'enseignement dans les territoires occupés, a successivement suscité, entre autres, deux phénomènes qui ne figuraient certainement pas au nombre de ses prévisions : d'abord la formation progressive d'un pubic lisant et s'exprimant en français, ensuite l'émergence d'une littérature également d'expression française. (GNAOULÉ-OUPOH, Bruno. La littérature ivoirienne. Paris: Karthala; Abidjan: CEDA, 2000. p. 12).
} 
O sistema de ensino colonial teve sua primeira escola oficial aberta em agosto de 1887, por iniciativa de Arthur Verdier, navegador e comerciante francês, instalado em uma província da Costa do Marfim, cuja intenção se limitava a formar os homens da região a fim de solucionar os problemas imediatos de seu comércio e das plantações locais.

A mesma necessidade detectada por Verdier levaria o governador da colônia, Binger, a assinar uma convenção entre a administração local e a congregação das Missões Africanas de Lyon para garantir a eficácia do ensino, por ele julgado insuficiente, e servir de apoio ao empreendimento colonial, multiplicando as escolas destinadas a divulgar a língua e a influência da França. ${ }^{79}$ Vimos, com isso, que o desenvolvimento do ensino em língua francesa só se efetuou a partir da necessidade de expansão e domínio do colonizador $^{80}$, sendo o desenvolvimento da literatura uma conseqüência natural da expansão do ensino e, posteriormente, da abertura das universidades e formação dos futuros intelectuais do continente africano.

Quando a organização do ensino público passa à administração federal, ou seja, quando a administração colonial estabelece uma nova política escolar orientada a partir de Dakar ${ }^{81}$, a expansão do ensino público tem o mérito de estender sua ação às diversas regiões dos países colonizados, mas o demérito de provocar, pela proposta de organização do ensino que dividia as escolas em rurais, regionais e urbanas, a oficialização da exclusão. Enquanto as escolas rurais eram mantidas por monitores africanos cuja principal atribuição era dar os rudimentos de língua francesa, de higiene e de cálculo [as escolas urbanas]

79 ... les écoles destinées à répandre la langue et l'influence de la France. (R. P. GOUJU apud GNAOULÉ-OUPOH, 2000, op. cit., p. 17).

80 Outro ponto que merece atenção por corroborar com o desejo de promover a submissão do colonizado é a instauração tardia do ensino feminino. Este só se produziu, com efeito, a partir do momento em que os padres responsáveis por parte das escolas oficiais concluíram que apenas com a formação de núcleos familiares cristãos poderiam garantir o sucesso das Missões, uma vez que haviam constatado que os convertidos retornavam ao seu meio de origem.

${ }^{81}$ Dakar tornou-se a sede da AOF (Afrique-occidentale française) que regia o conjunto das colônias africanas e da qual emanavam as leis e decretos que organizavam as colônias no plano político, econômico, social e, na medida de seus interesses e necessidades, também no plano cultural. 
foram criadas com o objetivo de satisfazer as necessidades de escolarização dos filhos e filhas de europeus e de funcionários africanos que dominassem bem o francês e que vivessem "à moda européia". ${ }^{82}$ Além da inserção do modelo, tal valoração do modus vivendi europeu não deixará de ter implicações diretas nas literaturas africanas, cuja produção é fortemente inspirada pela realidade imediata. Mesmo quando os escritores se empenham em recuperar a tradição, sem fazer qualquer menção ao momento histórico vigente, trata-se de um resgate que visa enaltecer os méritos e as virtudes dos grandes homens, da estrutura social e costumes tradicionais.

A imposição da língua e de hábitos europeus a uma cultura social e politicamente organizada só poderia provocar a reação de parte da população que permanecia refratária ao domínio francês. Não é, portanto, de se admirar que, em poucos anos de existência, a literatura escrita africana tenha mudado suas feições. Se, por um lado, o sistema educacional colonial permite o surgimento da literatura escrita nos moldes metropolitanos, por outro, as dimensões políticas e socioculturais dessa inserção de valores e modelos franceses criam as condições ideais para o surgimento de obras elaboradas, sobretudo, a partir da reação ao totalitarismo e aos abusos cometidos contra o povo africano. Com a recuperação da tradição, as literaturas africanas trazem à cena literária aquilo que a Europa tentou condenar ao esquecimento: a cultura africana pré-colonial. Em entrevista concedida a Edouard Maunick (2002), Léopold Sédar Senghor relembra sua experiência pessoal com a instrução francesa que tinha como objetivo principal caracterizar a barbárie da cultura africana:

Foi nos anos 20, eu estava no seminário Libermann; o diretor, o padre Lalouse, era realmente um educador: ele queria, como nos dizia com freqüência, fazer de nós verdadeiros franceses negros. O padre Lalouse tinha o hábito de nos dizer que nós não éramos civilizados, que o que havia era uma tábula rasa e que era preciso nos ensinar a pensar, a agir

82 ... Donner des rudiments de langue française, d'hygiène et de calcul, [as escolas urbanas] ont été créées dans le but de satisfaire les besoins de scolarisation des fils et filles d'Européens et de fonctionnaires africains, maîtrisant bien le français et vivant «à l'européenne ». (GNAOULÉ-OUPOH, 2000, ibidem, p. 21). 
e até mesmo a sentir como os europeus, como os brancos, como os franceses, e eu me revoltava contra essa idéia e voltava ao passado. Eu pensava nos dias de Djilor, naquela vida de vilarejo que era ordenada como uma cerimônia, desde o amanhecer, os cumprimentos a meu pai com o esboço de genuflexão das mulheres e das moças, até às noites escuras, palpitantes, com seus contos e lendas. Tudo era organizado, tudo era digno, tudo era belo e, mais tarde, me lembraria dessa vida de Djilor ao ler Léo Frobenius falando dos Negros e dizendo que esses homens eram civilizados até os ossos. ${ }^{83}$

No prefácio aos Damnés de la terre, de Frantz Fanon, Sartre denuncia o processo de helenização do colonialismo, o engodo e as táticas de uma agressão imperialista:

A elite européia dedicou-se a fabricar uma elite indígena: selecionavam adolescentes, marcavam-Ihes na fronte, com ferro incandescente, os princípios da cultura ocidental, enchiam-lhes a boca de palavras sonoras, grandes palavras pastosas que prendiam aos dentes; após uma breve estada na metrópole, remetiam-nos para casa, completamente falsificados. Essas mentiras vivas nada mais tinham a dizer a seus irmãos; elas ressonavam; de Paris, de Londres, de Amsterdã lançávamos palavras "Partenão! Fraternidade!" e em alguma parte da África, da Ásia, lábios se abriam: "...Tenão! ...nidade!" Era a idade de ouro.

Chegou o fim: as bocas se abriram sozinhas: as vozes amarelas e negras falavam ainda de nosso humanismo, mas era para reprovar nossa inumanidade. Ouvíamos sem desgosto essas corteses exposições de amargura. Inicialmente, com altiva admiração: Como? Eles conversam sozinhos? Vejam o que fizemos com eles. Não duvidávamos que eles tivessem aceitado nosso ideal, pois que nos acusavam de não Ihes sermos

${ }^{83}$ C'était dans les années vingt, j'étais au collège séminaire Libermann, le père directeur, le père Lalouse était vraiment un éducateur, il voulait comme il nous l'a souvent dit faire de nous des Français noirs. Et le père Lalouse avait l'habitude de dire que nous n'avions pas de civilisation, qu'il y avait table rase, et qu'il nous fallait apprendre à penser, à agir et même à sentir comme les Européens, comme les Blancs, comme les Français et je me révoltais contre cette idée et je revenais en arrière. Je songeais aux jours de Djilor, à cette vie de village qui était réglée comme une cérémonie depuis le réveil du matin, les salutations à mon père avec l'esquisse de génuflexion des femmes et des jeunes filles jusqu'aux veillées noires palpitant de contes et de légendes. Tout était réglé, tout était digne, tout était beau et plus tard je me rappellerai cette vie de Djilor en lisant Léo Frobénius parlant des Noirs et disant que ces hommes étaient civilisés jusqu'à la moelle des os. (SENGHOR, Léopold Sédar. Léopold Sédar Senghor par lui-même. Propos recueillis par Édouard J. MAUNICK. In: NOTRE LIBRAIRIE : Revue des littératures du Sud. 1250 nouveaux titres de littérature d'Afrique noire 1997-2001. Paris : Clef, n. 147, jan.-mars 2002, p. 7). 
fiéis; a Europa acreditou em sua missão: helenizara os asiáticos, criara uma espécie nova, os negros greco-latinos. ${ }^{84}$

Sartre, em 1948, já havia feito a apreciação das conseqüências deste processo no plano literário: O que esperáveis que acontecesse, quando tirastes a mordaça que tapava estas bocas negras? Que vos entoassem louvores? ${ }^{85}$ Os rumos que a literatura negra tomou nos anos subseqüentes não fizeram senão ratificar as previsões Sartre: foi sendo conduzida pela conscientização de uma realidade histórica que considera tanto a valorização das tradições quanto a intervenção do imperialismo europeu, mas também visou estabelecer o balanço dessa dicotomia em benefício de uma constituição identitária, conforme aponta Charles Nokan:

A maioria dos escritores freqüentou a escola do colonizador e foram, portanto, parcialmente influenciados pela educação que receberam. Havia uma espécie de escola em cada região, em nossos diferentes grupos étnicos, mas tratava-se de uma escola cujo ensino era exercido junto aos pais [pois] essa era uma época de experiências, relacionada ao que os pais faziam, a tudo o que diziam; tudo era oral naquele momento; antes de sermos educados pela educação criada pelos ocidentais, criada pelos colonizadores, nós havíamos sido formados por esse tipo de educação que eu chamaria de educação africana, educação da etnia, [exercida] junto aos pais e que só pode ser feita por meio da experiência. Depois, tivemos na escola a cultura que o ocidente nos apresentou: a França ou a Inglaterra, dependendo da região da África. $E$ não há dúvida de que também adquirimos uma certa experiência e isso transforma parcialmente o indivíduo: temos um pouco de ambos, e isso pode aparecer nas atividades que exercemos (...), portanto, costumamos dizer que ambos se manifestam na obra. Cabe agora aos leitores, aos críticos verificar o que é mais influenciado pelo ocidente e o que é, em parte, influenciado por nossas culturas africanas. ${ }^{86}$

Vejamos, portanto, em que medida os topoi da narrativa oral tradicional determinaram os traços que constituem o moderno romance africano,

${ }^{84}$ SARTRE, Jean-Paul. Colonialismo e neocolonialismo (Situações V). Tradução: Diva Vasconcelos. Rio de Janeiro: Tempo Brasileiro, 1968. p. 137.

85 SARTRE, Jean-Paul. Orfeu negro. In: Reflexões sobre o racismo. Tradução: J. Guinsburg. São Paulo: Difel, 1961.

${ }^{86}$ NOKAN, Charles. Charles Nokan: Depoimento [mar. 2006]. Entrevistadora: Maria Suzana Moreira do Carmo. Abidjan, 2006. 1 fita cassete (60 min). Cf. Anexo I desta pesquisa. 
confirmando a alegação de M. MBoukou (1980, p. 231) de que o gênero romanesco africano não se limita a uma servil adaptação do romance francês.

\subsection{Mestres do discurso: do griot ao escritor moderno}

A sociedade tradicional, anterior ao tráfico negreiro, é definida por Amadou Koné (1980, p. 137) como uma sociedade fechada, na qual o principal objetivo consistia em salvaguardar a unidade e coerência do grupo. Seu sistema de organização contava com um princípio metafísico que se expressava por meio dos mitos e permitia o equilíbrio entre o homem e a natureza. Esses mitos regiam então as questões fundamentais da comunidade e eram ensinados pelos anciãos, verdadeiros guardiões da tradição e mandatários dos deuses e ancestrais, que tinham como função principal a manutenção do equilíbrio e o respeito aos valores do clã tais como a continuação da linhagem, ou a importância do princípio de descendência, o valor da virilidade, da coragem, e da fecundidade, entre outros. Como afirma Jacques Maquet (1968, p. 18-21), tudo o que o africano é e possui se deve a seu status como membro de uma linhagem, como descendente de um ancestral, cuja imagem é venerada como a de um ser forte e poderoso. $\mathrm{O}$ herói mítico se torna então um modelo em torno do qual gravita a narrativa tradicional e que gera a criação de personagens históricos como Soundjata, ancestral da região do Manding, cujos grandes feitos foram narrados por Djibril Tamsir Niane (1960) em Soundjata ou l'épopée du Manding. Sem grande densidade psicológica, o herói tradicional não tem dúvidas ou apreensões quanto ao papel que deve desempenhar em sua relação com os demais personagens, com a natureza ou as contingências da ação. Nesse mundo "fechado e perfeito", a questão fundamental não é saber se é preciso "ser ou 
não ser" mas, antes, como estar o mais alinhado possível com os valores considerados como os melhores. ${ }^{87}$

Amadou Koné identifica duas etapas na evolução do romance africano. A primeira, que constitui a formação do romance histórico, é caracterizada pelo processo de recriação de uma história antiga na qual o escritor não desempenha o papel de simples tradutor, mas reelabora o tema como se ele próprio a tivesse criado. Ser mais do que um simples tradutor é ainda uma característica que diferencia a atividade do romancista da transcrição direta da narrativa tradicional. O escritor, em parte ocidentalizado, deixa a sua marca de criador, daquele que possui uma certa autonomia que the permite parafrasear a história. Talvez tenha sido esta uma das razões que levaram alguns críticos a se perguntarem, por exemplo, em que medida Wangrin, personagem do romance L'Étrange destin de Wangrin, de Amadou Hampaté Bâ (1992), corresponde ao personagem real apresentado na advertência que precede 0 romance e qual seria a parte de inventividade com que o autor teria complementado o perfil e as façanhas do personagem. No posfácio, redigido em 1986, treze anos após a publicação do romance, Hampaté Bâ usa de fina ironia para esclarecer os mal entendidos relativos à autenticidade dos personagens e eventos narrados:

Desde a publicação deste livro, em 1973, alguns mal entendidos surgiram cá a lá, tanto no que concerne à personalidade real do herói quanto à própria natureza da obra. (...) Admite-se, em geral, a existência histórica daquele que se apelidou, ele próprio, de "Wangrin", mas acredita-se que devo ter "romanceado" um pouco sua vida, introduzindo uma dose sutil de tradição oral e eventos sobrenaturais de minha autoria, a fim de encorpar a história e Ihe dar uma espécie de significação simbólica.

Sinto-me extremamente lisonjeado pelo fato de que exegetas, que são, com freqüência, eminentes professores de literatura, atribuam a mim tais qualidades de criação literária. ${ }^{88}$

\footnotetext{
${ }^{87}$ Dans ce monde "clos et parfait", la question fondamentale n'est pas de savoir s'il faut "être ou ne pas être" mais plutôt comment être le plus en conformité avec les valeurs considérées comme les meilleures. (KONÉ, Amadou, op. cit., p. 137).

${ }^{88}$ Depuis la parution de ce livre en 1973, certains malentendus sont apparus çà et là tant sur la personnalité réelle du héros que sur la nature même de l'ouvrage. (...) On
} 
A segunda etapa é marcada pela maior liberdade com que o escritor elabora suas tramas, mesmo que seus romances ainda lembrem, direta ou indiretamente a tradição oral. Trata-se, portanto, de uma interpretação livre da narrativa tradicional. Além da formação européia dos escritores, que permitiu a mudança do código de expressão e o acesso ao cânone ocidental, um outro fato relevante para a gradual aquisição de liberdade de criação do escritor africano foi o afastamento do controle do público. As narrativas da tradição oral eram feitas para uma audiência que dominava o teor das histórias narradas e conhecia profundamente os mitos e heróis. Esse conhecimento fazia com que o público exercesse um controle sobre a fidelidade da narrativa, controle que desaparece com a alteração do suporte: o livro nas mãos do leitor admite certamente uma recepção crítica, mas não altera os rumos da narrativa como ocorria durante a transmissão oral. É exatamente por essa razão que a justificativa da procedência dos mitos e heróis narrados é recorrente nos discursos dos griots. Em Soundjata, o griot Mamadou Kouyaté garante ser merecedor de crédito quanto à História do Ancestral do grande Manding:

Ma parole est pure et dépouillée de tout mensonge; c'est la parole de mon père; c'est la parole du père de mon père. Je vous dirai la parole de mon père telle que je l'ai recue; les griots de roi ignorent le mensonge. ${ }^{89}$

Soundjata ou l' épopée du Manding é um romance histórico, cuja estrutura e função estão muito próximas da narrativa oral tradicional. Como vimos acima, L'étrange destin de Wangrin suscitou algumas suspeitas em

admet généralement l'existence historique de celui qui s'était surnommé lui-même «Wangrin », mais on pense que j'ai dû «romancer» quelque peu sa vie, $y$ introduisant même, pour corser l'histoire et lui donner une sorte de signification symbolique, un dosage subtil de tradition orale et d'événements surnaturels de mon cru. Je suis extrêmement flatté que des exégètes, qui sont d'ailleurs souvent d'éminants professeurs de littérature, m'attribuent de telles qualités de création littéraire. (HAMPATÉ BÂ, Amadou. L'étrange destin de Wangrin : ou Le Roueries d'un interprète africain. Paris: 10/18, 1992. p. 359).

89 NIANE, Djibril T. Soundjata ou l'épopée du mandingue. Paris: Présence Africaine, 1960. p. 10. 
relação à credibilidade dos eventos narrados. Se Hampaté Bâ garante a veracidade de sua narrativa e de sua fonte, pela "palavra" recebida do próprio Wangrin, a dúvida traz o reconhecimento implícito da atuação da imaginação do autor. Quando examinamos o romance de Ahmadou Kourouma, Les Soleils des indépendances, temos uma imagem muito tênue do griot da sociedade tradicional. Diamourou, descendant des griots honorés de la famille Doumbouya (KOUROUMA, LsdI, p. 107), apresenta um discurso competente e tenta manter o prestígio de sua casta, mas não evoca a autenticidade de seu discurso. Diamourou, personagem de Kourouma, é o griot da moderna criação literária africana que, além de estar distante da respeitosa audiência de outrora e ter perdido sua função de memória reguladora da sociedade e do clã, é fruto do esfacelamento da sociedade tradicional em benefício dos novos ventos das independências, sendo que ele próprio tira proveito da situação, vivendo às expensas da filha e dos netos, que enriqueceram graças ao novo poder e à nova administração.

A passagem da narrativa do griot à narrativa do escritor moderno é, portanto, marcada por um processo evolutivo que se inicia na narrativa oral tradicional, passa pelos romances históricos que compreendem uma espécie de tradução, ou transcrição, dos grandes temas míticos e históricos, até chegar ao moderno romance africano. Neste momento, a imaginação e a criatividade individual desempenham um papel preponderante sem, contudo, abandonar totalmente a estrutura da narrativa tradicional.

Além de certa submissão ao cânone ocidental e da liberdade adquirida para expressar sua individualidade e ideologia, a alteração do código da comunicação, do oral ao verbal, também permite que o escritor prolongue, de certo modo, a atuação do griot.

Esboçando um esquema comunicacional da narrativa tradicional, Amadou Koné aponta a dupla função do escritor moderno: além de assumir o lugar do griot, ou seja, o lugar do emissor das histórias exemplares da tradição, também assume o papel do agente rítmico cujas intervenções musicais foram substituídas, no novo código, pelos acréscimos do enredo e 
pelo estilo do autor, enriquecendo a mensagem e permitindo a introdução da ideologia do autor. Assim, o autor moderno, por sua liberdade em tratar a tradição oral, torna-se um verdadeiro criador ou, antes, um recriador. ${ }^{90}$

Um dos traços que distinguem o griot do escritor moderno africano é o fato do griot não ser um criador na concepção ocidental do termo. Aliás, no momento em que o autor africano ganhava autonomia e liberava sua imaginação, na França, teóricos como Barthes e Foucault ${ }^{91}$ opunham-se à tradição clássica e propunham, num movimento vanguardista, a morte do autor. Dito isso, assinalamos um dos pontos de divergência, tanto na produção literária quanto na crítica, entre metrópole e ex-colônias. Isso não significa que o privilégio da escritura em detrimento do autor não possa constituir uma via possível de análise das literaturas africanas, mas no estágio em que estas se encontravam no período historicamente conhecido como a era das reivindicações e das lutas pela liberação e os anos subseqüentes às Independências, esse modelo de leitura de uma obra africana constituiria praticamente um anacronismo. Nessa passagem da tradição oral à escritura, a ideologia do autor e o momento histórico são partes integrantes da narrativa.

O griot no exercício de sua função tem algo que se assemelha ao antigo poeta, aquele para quem narrar uma história era essencial, e o narrar uma história e o declamar o verso não eram pensados como coisas diversas (BORGES 2000, p. 59). Embora os mitos da tradição heróica possam variar de uma região a outra, embora as narrativas heróicas, que relatam as proezas e enaltecem as virtudes, sejam condicionadas pela história local, o griot também tinha sua parte de criador, mas sua criação se limitava à reconstituição de suas fontes e, portanto, à reorganização de um enredo já bastante familiar ao público. Para que pudesse cumprir a sua função ou, como prefere Makouta MBoukou (1980, p. 231), a sua missão, a narrativa necessitava dois cuidados:

90 ... I'auteur moderne par la liberté qu'il a de traiter la tradition orale devient un véritable créateur ou plutôt un recréateur. (KONÉ, Amadou, 1985, op. cit., p. 64).

${ }^{91}$ Cf. FOUCAULT, M. Qu'est-ce qu'un auteur. In : Dits et écrits. Paris : Gallimard, 1994. p. 789-821; BARTHES, R. La mort de I'auteur. In : Le bruissement de la langue: Essais critiques IV. Paris: Seuil, 1984. p. 63-69. 
a preservação do enredo, com a precisão dos dados míticos ou históricos, e o rigor na elaboração do discurso; e é precisamente esse dom da manipulação, ao mesmo tempo bela e eficaz, do discurso que faz do griot um ser digno do epíteto "mestre do discurso".

Segundo Pierre Alexandre (1968, p. 192), há duas origens possíveis do vocábulo griot; a primeira seria uma variação da palavra "criado", servidor, de origem portuguesa; a segunda, uma deformação francesa da deformação portuguesa do wolof gewel. Pertencentes a uma casta profissional endogâmica, podem ser encontrados tanto nas cortes reais, desempenhando o papel de historiadores e genealogistas, quanto nas cidades e vilarejos, atuando como contistas, arautos, bufões, músicos, aduladores ou difamadores, ou ainda veiculadores orais de notícias. Seja como for, sua posição subserviente de escravo sem senhor lhes garante uma boa parcela de liberdade. Mesmo quando ocupam posições importantes junto aos chefes e adquirem, como conselheiros, uma real projeção e importância política, os griots não são submetidos às regras sociais que regem a comunidade. De acordo com a etnia à qual pertencem, a organização interna da casta dos griots pode variar, mostrando-se ora homogênea, ora dividindo-se em sub-castas ou linhagens.

Dentre os griots ligados a famílias reais ou a famílias importantes, Christiane Seydou ${ }^{92}$ distingue três tipos que possuem a mesma função: o farba (senegalês), o mâbo (peulh) e o djeli (malinké) ${ }^{93}$. Junto a essas famílias, suas atribuições compreendem a exposição dos grandes feitos e das sentenças simbólicas ou normativas do clã com o objetivo de glorificar e edificar os heróis da História, e o exercício do papel de conselheiros. Já os griots ambulantes, como o gwalo (peulh) ou o nyamakala (malinké), não possuem propriamente uma função nobre; embora cantem louvores aos homens livres, seu meio de vida provém da extorsão de dinheiro por meio da adulação ou ameaça de ridicularizar a audiência. Como ressalta Pierre Alexandre:

92 SEYDOU, Christiane apud KONÉ, Amadou, 1985, op. cit., p. 23.

${ }^{93}$ A grafia de alguns termos encontrados na bibliografia consultada sobre os griots pode variar sensivelmente. No caso de djeli, encontramos a forma jèlí, em Camara Sory. Quanto a Soundjata, também podemos encontrar a grafia Soundiiata. 
Isso acontece freqüentemente sob encomenda, por ocasião de uma festa familiar, de uma campanha eleitoral, etc., mas também pode proporcionar uma verdadeira chantagem por parte do griot a quem sua vítima deve oferecer um regalo a fim de cessar um acúmulo de elogios que se tornaria perigoso, "sobrecarregando", de certa forma, o ego da pessoa elogiada, ou então atraindo sobre ela a atenção de espíritos ou gênios perigosos. Na verdade, que ele bajule ou vitupere, é impossível recusar um regalo ao griot, a ponto deste consegui-lo, com freqüência, sem mesmo precisar exercer a sua arte. ${ }^{94}$

Não se pode considerar tal adendo à arte do griot como algo lisonjeiro. Embora as sociedades do oeste africano, região colonizada pelos franceses e que nos interessa particularmente, sejam as que mais discriminam a casta dos griots, nossa atenção está voltada nesse estudo para o "mestre do discurso", o "poeta oficial" cuja narrativa tem o objetivo de educar dentro do espírito da tradição, aqueles cujo discurso pretende:

... agradar, distrair, entusiasmar, ensinar e manter intacta a arquitetura de uma sociedade que acredita ter resolvido seus problemas maiores $e$, portanto, não se questiona. ${ }^{95}$

Os griots, historiadores, cronistas, poetas e educadores, descendem de uma casta relativamente apartada da sociedade e têm em seu ofício um importante legado. A natureza da transmissão de seu conhecimento compreende a intenção explicita de impressionar o público e trazer-lhe um modelo de valores que se refletem na conduta do herói, e no interior da

${ }^{94}$ Cela se pratique souvent sur commande, à l'occasion d'une fête de famille, d'une campagne éléctorale, etc., mais peut aussi donner lieu à un véritable chantage de la part du griot à qui sa victime doit donner un cadeau pour arrêter une accumulation d'éloges qui deviendrait dangereuse en « surchargeant » en quelque sorte l'ego de la personne louangée ou encore en attirant sur elle l'attention des esprits ou génies dangereux. En fait, soit qu'il encense, soit qu'il vitupère, il est impossible de refuser un cadeau au griot, au point que celui-ci l'obtient bien souvent sans même avoir à exercer son art. (ALEXANDRE, Pierre. Griots. In : BALANDIER, Georges et MAQUET, Jacques (Dir.). Dictionnaire des civilisations africaines. Paris : Fernand Hazan, 1968. p. 193).

95 ... à plaire, à distraire, à enthousiasmer, à enseigner et à maintenir intacte l'architecture d'une société qui croit avoir résolu ses problèmes majeurs et donc ne se remet pas en question. (KONÉ, Amadou, ibidem, p. 23). 
narrativa, encontraremos a reprodução exata do griot narrador, ou seja, o glorificador da ação de seu mestre que exorta o herói à ação, narra suas proezas e exalta suas virtudes.

O cenário literário que abriga o primeiro romance de Kourouma encontra-se em estágio acentuado de liberação do escritor ${ }^{96}$. Mesmo que a sociedade tradicional continuasse sendo uma fonte inesgotável de motivos temáticos, o controle exercido pelo público da narrativa oral havia desaparecido. A supressão do crítico e censor imediato, cuja exigência de fidelidade à História restringia o papel do narrador à manipulação competente do discurso, permitiu o livre curso da imaginação do autor.

Esse é o momento em que, dentro do esquema comunicacional, o escritor assume o papel de emissor independente, abandonando a função de intérprete ou recriador de uma história antiga. Entretanto, isso não significa que os temas tradicionais tenham sido totalmente abandonados, a diferença reside no tipo de tratamento dado ao texto, que se singulariza por efeito da introdução da imaginação e ideologia do autor. Se o escritor utiliza episódios da memória tradicional, com referências a personagens, datas ou eventos históricos, a óptica pessoal prevalece em detrimento da fidelidade histórica.

${ }^{96}$ Esse momento coincide com uma vasta produção de romances que sucederam o processo das independências do oeste africano. Dentre as obras de maior destaque, selecionamos, a título de exemplo, alguns romances que figuram na extensa lista de publicações recenseadas po Pius NGANDU Nkashama em Les années littéraires en Afrique (1912-1987): L'aventure ambiguë (1961), de Cheikh Hamidou Kane (Senegal) ; L'Harmattan, tome I: Le referendum (1964), Le mandat (1965) e Xala (1973) de Ousmane Sembene (Senegal) ; Le chant du lac (1965), de Olympe BhelyQuenum (Benin) ; Violent était le vent (1966), de Charles Nokan (Costa do Marfim); Les Soleils des indépendances (1968), de Ahmadou Kourouma (Costa do Marfim) ; Le devoir de violence (1968), de Yambo Ouologuem (Mali) ; Les fils de Kouretcha (1970), de Aké Loba (Costa do Marfim) ; En quête de liberté (1970) e Les exilés de la forêt vierge ou Le grand complot (1974), de J.-P. Makouta-MBoukou (Congo); Les jeux du destin (1970), de Fily Dabo Sissoko (Mali); Le cercle des tropiques (1971) e Le récit du cirque... de la vallée des morts (1975), de Alium Fantouré (Guiné); L'étrange destin de Wangrin ou Les roueries d'un interprète africain (1973), de Ahmadou Hampaté Bâ (Mali) ; Un fusil dans la main, un poème dans la poche (1973), de Emmanuel Dongala (Congo); Saint Monsieur Baly (1973), de Williams Sassine (Guiné) ; Perpétue ou I'habitude du malheur (1974), de Mongo Beti (Camaroes). 
Em Les Soleils des indépendances, a ideologia do autor emerge à superfície do texto. A responsabilidade da colonização pela morte da África tradicional é evidente e a recuperação da cultura tradicional não tem a função de restituir o brilho a essa tradição, mas a de exibir a ruína de uma identidade coletiva e, sobretudo, a de estabelecer o contraste entre um passado que dava dignidade ao homem africano e a miséria que, em primeiro plano, pertence a Fama, mas em segundo, a toda a geração do período histórico que compreende a transição das independências e seus descendentes. A primeira aparição de Fama no romance é feita sob o signo da vergonha e da humilhação:

C'étaient les immenses décheance et honte, aussi grosses que la vieille panthère surprise disputant des charognes aux hyènes, que de connaître Fama courrir ainsi aux funérailles. ${ }^{97}$

O escritor escreve agora em seu nome, em nome de suas aspirações e de seus compromissos ideológicos; suas opiniões não são oficiais e o narrador, isento de compromisso com a comunidade, pode expressar livremente seu julgamento a respeito da trama ou dos personagens. Assim, em Les Soleils des indépendances, por exemplo, temos a apreciação do narrador com relação ao sarcasmo com que Fama é recebido nos funerais:

Que voulez-vous? Un prince mendiant c'est grotesque sous tous les soleils. ${ }^{98}$

A evolução do romance africano permitiu, portanto, que o escritor, cada vez mais influenciado pela cultura ocidental, se apartasse dos compromissos que o narrador tradicional tinha para com o seu público. Suas convicções e aspirações sócio-políticas ou suas crenças religiosas encontram, agora, livre curso de expressão. Apartando-se dos temas e dos heróis tradicionais, os

\footnotetext{
97 KOUROUMA, LsdI, op. cit., p. 12.

98 KOUROUMA, idem, p. 11.
} 
escritores podem enfim criticar e buscar alternativas para as questões discutidas em seus enredos.

O romance moderno africano nasce, de fato, da introdução da cultura escrita ocidental no continente, mas não deixa de ter uma ligação genética com a narrativa heróica tradicional. Depois de uma breve passagem pelo romance histórico, no qual o escritor torna-se uma espécie de intérprete do passado, o romance expressa posicionamentos pessoais sem, contudo, negligenciar as grandes questões coletivas ou a tradição. Considerando-se a história recente do continente africano, as questões coletivas são, em geral, referidas em relação às mazelas provocadas pela colonização e póscolonização, responsáveis pelo desequilíbrio e destruição das instituições tradicionais. Não é, portanto de se admirar que a crítica literária referente às literaturas africanas tenha privilegiado as relações entre a sociedade e a obra literária: Georges Lukács, Lucien Goldmann e Mikhail Bakhtin são teóricos recorrentes nos estudos referentes às literaturas africanas e ao contexto colonial e pós-colonial. A respeito dessas contingências e nova cepa de escritores, Amadou Koné comenta:

Tudo acontece como se esses homens, inseridos num mundo degradado, um mundo com valores doravante inautênticos, os "sóis da bastardia", diria Fama, escolhessem contemplar o passado com nostalgia e, se possível, salvar determinados valores condenados, mas sempre considerados como vitais, ou então desmistificar um passado que não Ihes parece admirável. ${ }^{99}$

É essa visão nostálgica que parece, efetivamente, prevalecer nos romances modernos, ou seja, naqueles que, embora mantenham certa ligação com o passado, afastaram-se do modelo tradicional e ganharam autonomia suficiente para a expressão pessoal do autor.

${ }^{99}$ Tout se passe comme si ces hommes, placés dans un monde dégradé, un monde aux valeurs désormais inauthentiques, les « soleils de la bâtardise », dirait Fama, choisissent ou bien de contempler le passé avec nostalgie et si possible de sauver certaines valeurs condamnées mais toujours considérées comme vitales, ou bien de démystifier un passé qui lui-même ne leur paraît pas admirable. (KONÉ, Amadou, ibidem, p. 138-139). 


\section{A narrativa tradicional: fonte temática e procedimentos narrativos}

Em "Les origines inavoués du genre romanesque négro-africain", J.-P. Makouta Mboukou aponta o amadurecimento do romance francês, precursor do romance africano de língua francesa, como o resultado de uma longa evolução cuja forma mais bem elaborada encontramos em autores como Stendhal, Balzac, Zola e Proust, dentre outros. Embora reconheça este gênero como uma das expressões literárias mais apropriadas para que o homem se defina, no tempo e no espaço e em sua condição de ser que marcha, inexoravelmente, em direção ao seu destino, não deixa de observar que nada prova que a forma do romance escrito em conformidade com os princípios elaborados pela alma do Ocidente convenha perfeitamente à nossa alma ${ }^{100}$ [do homem negro-africano]. Na verdade, o autor refere-se aqui à técnica estrutural do romance ocidental, mas no que diz respeito às temáticas recorrentes nos romances africanos em geral, reconhece o reflexo de escritores profundamente enraizados no continente africano, com tudo o que este continente comporta de tradições, crenças e organização social e política. Quer se trate de um traço deliberado, quer represente uma manifestação não intencional, inconsciente, os escritores africanos deixam sempre entrever, em maior ou menor grau, as marcas da sociedade tradicional africana e a herança da narrativa oral. É sob este ângulo, portanto, que verificamos agora os principais aspectos das temáticas desenvolvidas nas narrativas heróica e iniciática, bem como o grau de sua refração no moderno romance africano.

100 ... rien ne prouve que la forme du roman écrit en conformité avec les principes élaborés pour l'âme de l'Occident convienne parfaitement à notre âme. (MAKOUTAMBOUKOU, 1980. op. cit., p. 204). 


\subsection{Injustiça e espoliação}

É preciso, inicialmente, distinguir os principais gêneros da produção literária da África tradicional: a narrativa heróica, que compreende a epopéia, e a narrativa iniciática, que abrange o mito e tem o objetivo de elevar a compreensão e proporcionar um nível incomum de sabedoria ao iniciado.

Do ponto de vista temático, esta narrativa tradicional baseia-se na luta contra uma injustiça ou algum tipo de usurpação. A narrativa heróica parte de um desejo de reabilitação da honra e a trama se desenvolve em torno do dilema do herói espoliado. Isso equivale a dizer que a intriga envolve necessariamente o destino de um eleito. Ainda que a base dessa intriga compreenda uma espoliação dos direitos de um nobre descendente e que este se veja, portanto, desprovido dos privilégios que atestavam sua singularidade e importância diante dos demais, ainda assim o herói tradicional é um homem de prestígio, um indivíduo cujo destino foi agraciado com a prerrogativa do direito à luta pela honra e pela restituição de sua glória.

O tema da espoliação, recorrente no romance moderno africano, tem, portanto, duas fontes distintas: a ascendência da narrativa tradicional e o resultado de uma ação de denúncia e reivindicação frente à usurpação dos direitos do homem negro pelo Ocidente, que compreende desde o tráfico negreiro até a implantação do neocolonialismo. A ênfase que diversos especialistas têm dado ao engajamento do romance africano como veículo de denúncia, contestação e até mesmo como veículo privilegiado de informação, se sobrepõe e minimiza os traços herdados da narrativa tradicional, quando não os oculta totalmente. É no sentido de considerarmos este importante legado que trazemos à luz as principais características da narrativa tradicional, a fim de que seus vestígios possam ser melhor detectados no romance moderno africano.

Em Les soleils des Indépendances, a espoliação é o tema fundamental que guia as ações do herói e serve de base à intriga, embora Fama, o príncipe que teve seus direitos usurpados pela administração colonial, esteja longe de 
ser comparado aos heróis tradicionais. Sua luta é, sem dúvida, precedida pelo desejo de uma reabilitação, mas o espaço e o tempo histórico deixaram de ser aqueles que propiciavam a legitimidade da luta nas sociedades tradicionais. Fama encontra-se no momento da constatação de que a independência da Côte des Ébènes, à semelhança do que ocorreu em grande parte do território africano, não passava de falácia que escondia o que Diandué Bi Kacou Parfait (2003) classificou como as políticas corrosivas e liberticidas da África. Kourouma descreve, de fato, uma busca pelos chamados valores autênticos, mas seu herói não possui a glória dos heróis tradicionais, ao contrário, sua busca se revela estéril, à semelhança de sua esterilidade objetiva, e desenvolve-se como meio de instruir a respeito das vicissitudes dos povos africanos. A despeito dos resultados obtidos, não se pode descartar a homologia entre a busca de Fama e aquela que impulsionou o herói da narrativa tradicional.

\subsection{A viagem imaginada e o deslocamento efetivo}

Dentro da concepção tradicional, sair à procura do restabelecimento da própria honra, da restituição de direitos usurpados, pode tomar a forma de um deslocamento efetivo, como ocorre na epopéia. No caso da narrativa iniciática, esse deslocamento não precisa ser necessariamente uma alteração do espaço físico, essa viagem podendo assumir o aspecto de um movimento interior, de uma espécie de errância interna cujo termo terá sido o amadurecimento do herói. Nesse caso, podemos ainda entender a busca, o deslocamento, como a longa trajetória do indivíduo que, de uma experiência à outra, alcança finalmente a almejada sabedoria. Isso é o que podemos observar no conjunto de textos que constituem os Kuma Kodoba ou Paroles très anciennes, narrativa da tradição oral Mandenka ${ }^{101}$, reunidos por Sory Camara:

${ }^{101}$ Fundadores de um dos maiores impérios do oeste africano, o Império Medieval do Mali. Os Mandenka têm especial orgulho de seu passado que contou com grandes 
Les paroles très anciennes

C'est comme les graines

Tu les sèmes avant les pluies

La terre est chauffée par le soleil

La pluie vient la mouiller

L'eau de la terre pénètre dans les graines

Les graines se changent en herbes

Puis deviennent des épis de mil

Ainsi toi à qui je viens de dire la Parole très ancienne

Tu es la terre

J'ai semé en toi la graine de la parole

Il faut que l'eau de ta vie pénètre en la graine

Pour que la germination de la parole ait lieu ${ }^{102}$

Essa citação encerra a principal função pedagógica da viagem iniciática, ou seja, ao final de sua jornada, depois de passar por várias experiências, o indivíduo acaba por entender o sentido oculto dos discursos de iniciação. Os textos analisados por Camara Sory reúnem a riqueza de tradições orais que compõem parte do repertório dos soma, mestres ou iniciadores, anciãos dos vilarejos da mata. Segundo o autor, o conhecimento das Paroles très anciennes só pode ser adquirido após uma longa e paciente assiduidade no contato com os anciãos, que transmite seus ensinamentos ao jovem de sua escolha num momento em que este vive um drama semelhante a uma situação mítica. ${ }^{103}$ Mas cabe ao discípulo a tarefa de desvendar os mistérios dos ensinamentos e, por essa razão, o mestre se priva de comentá-los, a fim de que, em sua viagem através da existência, descubra por si mesmo a complexa evolução do ser humano.

As viagens imaginadas da narrativa iniciática e os deslocamentos concretos da narrativa heróica constituem, portanto, os principais temas da

caçadores, guerreiros e comerciantes que, durante todo o período medieval, cruzaram de norte a sul a África ocidental, o que propiciou sua conversão ao islamismo e, posteriormente, sua dispersão em agrupamentos que hoje se encontram no Mali, Senegal, Guiné e Costa do Marfim.

102 CAMARA, Sory. Paroles très anciennes ou le mythe de l'accomplissement de I'homme. Grenoble: La pensée sauvage, 1982. p. 8.

103 ... au jeune homme de leur choix en un moment où celui-ci vit un drame semblable à la situation mythique. (CAMARA, Sory, idem, p. 8). 
tradição oral. O que distingue os percursos de ambas é efetivamente a questão da espacialidade, pois enquanto na primeira o espaço privilegiado encontra-se no imaginário e a busca se conclui por inferência dedutivo-cognitiva, na segunda, o deslocamento é real e a conclusão compreende, em princípio, o resgate daquilo que foi usurpado ou do direito confiscado.

O romance histórico, como herdeiro da narrativa oral, recupera o tema da luta que visa a restituição da honra ou a recusa de uma espoliação. Em Soundjata ou l'épopée du Manding, de Djibril Tamsir Niane (1960), o movimento ocorre em termos de afastamento involuntário e retorno deliberado. Soundjata, criança mutilada e herdeira do trono, será espoliado em seus direitos por seu meio irmão Dankara Touman. Exilado pela madrasta que teme que os oráculos que predisseram um grande destino para ele se cumpram -, Soundjata retorna com o intuito de reconquistar seu reino e retomar o trono que lhe foi usurpado. Sua busca caracteriza-se então pela luta em busca da honra, a qual só Ihe será restituída com o deslocamento real do herói.

Makouta Mboukou atribui ao romance moderno africano o mérito de preencher o vazio deixado pelo desconhecimento e impossibilidade do homem de testemunhar os diversos fatos de cultura. Para ele, o tema da viagem, real ou imaginária, teria então uma missão informativa: mesmo que não se trate de autênticos documentos históricos, o leitor ocidental se enriquece pelo realismo e verdade do romance africano, enquanto o leitor africano toma conhecimento de agrupamentos, famílias, clãs, etnias e países negros cujos traços até então ignorava ${ }^{104}$. Que o romance, como a literatura em geral, tenha um certo valor etnológico e uma função informativa, isso é inegável, mas o alcance atribuído à literatura por Makouta Mboukou é um fato a ser reconsiderado, afinal, o acesso restrito do africano à leitura é um dado que não

$104 \mathrm{O}$ autor inclui ainda neste grupo as viagens ao Ocidente com as quais os romancistas preenchem a lacuna de muitos, ou seja, eles desvendam as experiências do africano em lugares onde tudo difere da realidade africana e, sobretudo, relata a difícil adaptação do homem negro a um mundo e a um clima distinto do universo africano sob todos os aspectos. 
pode ser negligenciado. É importante ressaltar os inúmeros problemas de ordem editorial, de distribuição, de custos na comercialização e dificuldade de aquisição que impedem a ampla divulgação e acesso ao que o autor considera um importante veículo de informação. Muitas vezes, já se tentou compensar a perda ou suposta inexistência de documentos com fontes indiretas, dentre as quais encontra-se a narrativa de fiç̧ão. Walter Burkert (1991, p. 77) lamenta, por exemplo, a escassez de textos dos mistérios pagãos relacionados à teologia de mistério, o que levou os especialistas a se debruçarem sobre a interpretação das narrativas de ficção como forma de suprir essa deficiência. Esperemos então que, num futuro distante, o conhecimento da riqueza da tradição africana não tenha o mesmo destino dos mistérios pagãos e que seu estudo não dependa apenas das obras ficcionais. As literaturas africanas desempenham, de fato, um papel importante na descrição dos costumes, mas os contornos que os romances começaram a adquirir depois da década de 90 demonstram que os autores desvencilharam-se, gradativamente, do momento histórico que caracterizou o retorno às fontes para mergulhar em questões de ordem mais universais e metafísicas.

\subsection{Estética e composição na narrativa heróica}

A narrativa heróica é feita pela exibição de quadros ou cenas que possuem uma relativa autonomia com relação ao conjunto da obra. No estudo supracitado de Camara Sory, as paroles très anciennes são compostas por tali, organizações narrativas mais simples que desenvolvem um único tema tratado por cada episódio das Paroles très anciennes. Os tali seriam, portanto, o equivalente das cenas autônomas da narrativa heróica, enquanto as Paroles très anciennes corresponderiam ao completo desenvolvimento da intriga de uma narrativa heróica tradicional.

A despeito da aparente independência desses quadros, o desenvolvimento da narrativa corresponde a uma ordenação de cenas 
sucessivas, de modo a compor o que Christiane Seydou chamou de progressão dramática elaborada ${ }^{105}$. Embora fosse permitido que o griot isolasse determinado episódio da narrativa a fim de intensificar um dos aspectos do herói ou da trama que melhor se adaptasse às circunstâncias do momento, a ordenação dos quadros obedecia a critérios relativamente rigorosos, dentre os quais a seqüência cronológica. Do nascimento à morte do herói, o narrador perfaz a trajetória do herói, enfatizando suas perdas e enaltecendo seus méritos.

Dentro desse conjunto de quadros, a ação se desenvolve em etapas sucessivas e a trama progride de modo relativamente simples. Como vimos anteriormente, as narrativas tradicionais partem de uma espoliação e da necessidade de se reparar uma falta e resgatar a honra. As intrigas psicológicas e os conflitos subjetivos, que exigem a introspecção do personagem, são questões que surgem posteriormente no romance africano, por influência da literatura ocidental. Considerando-se a função didática das narrativas tradicionais, compreende-se facilmente a exclusão dos conflitos psicológicos, cuja complexidade tenderia a diluir o caráter exemplar da narrativa e a enfraquecer os atos de bravura do herói.

O mesmo não acontece com a intervenção do maravilhoso que faz parte da sociedade africana à qual a narrativa tradicional se refere. Esse recurso dramático não tem nada de artificial ou gratuito; ao contrário, dentro de uma concepção de literatura que tem um pacto com o mundo real, o sobrenatural não poderia deixar de comparecer, posto que é um elemento recorrente na vida dos povos africanos. Esse maravilhoso que ainda povoa inúmeras páginas dos romances africanos corresponde, portanto, à expressão do concreto herdada da tradição oral, uma realidade nem sempre palpável, mas perfeitamente adequada ao perfil da tradição. Se empregarmos uma terminologia ocidental, podemos dizer que o romance africano tende ao gênero realista, que não apenas reflete a realidade do continente, mas "explica" e

105 ... une progression dramatique élaborée. (SEYDOU, Christiane apud KONÉ, Amadou, 1985, op. cit., p. 47). 
"fala" realmente aos negros da África ${ }^{106}$. Este traço do romance africano moderno tem sua origem na descrição tradicional: os heróis espoliados, que lutam para resgatar sua honra, são personagens históricos cujas trajetórias são conhecidas por todos. O caráter exemplar da narrativa tradicional exige uma certa identificação por parte da audiência com o modelo narrado e, por essa razão, a presença constante do maravilhoso não excede o objetivo didático, mas, ao contrário, reforça a empatia por se tratar de um dado comum à realidade da platéia. Além disso, as imagens que constituem a presença do maravilhoso são retiradas da tradição e não do inconsciente do griot que, aliás, não tem nenhuma liberdade de criação propriamente dita. Os procedimentos narrativos da tradição não exigiam a atuação do imaginário do narrador, e um dos fatores que contribuíam para que fosse admirado em seu ofício era, precisamente, a fidelidade ao modelo original.

A arte do griot consiste em exibir uma performance que possa encher o público de admiração pelo herói na medida em que este se dirige ao cumprimento de seu destino. É por essa razão que o griot recorre a uma espécie de "realismo metafísico" (KONÉ, A., 1985, p. 48), unindo a realidade material à exploração do maravilhoso. Assim como as batalhas narradas pelo griot na epopéia ocorreram de fato na História, os episódios nos quais o maravilhoso entra em cena também se referem à realidade da sociedade africana tradicional: daí o caráter realista dessas narrativas. Tanto os personagens da narrativa heróica quanto aqueles que povoam a narrativa

106 ... "explique" et "parle" réellement aux Nègres d'Afrique. (MAKOUTA-MBOUKOU, 1980. op. cit., p. 226). A esse respeito, Makouta Mboukou é enfático ao criticar o romancista africano que escreve "para" o ocidente. Embora reconheça a dependência do autor com relação à técnica estrutural do romance ocidental como origem de um vínculo indelével, aponta os riscos de um distanciamento da realidade africana: Ele [o escritor] tentou satisfazer o leitor do ocidente porque este sempre foi seu juiz em detrimento dos leitores negro-africanos, cujo gosto conhece relativamente bem. Se criar um gênero romanesco de acordo com o espírito negro-africano, talvez seja abandonado pela critica ocidental! Talvez perca o acesso aos prêmios literários aos quais já está habituado e que o leva, de maneira insidiosa, a se assimilar, a se "prostituir". [S'il crée un genre romanesque conforme à l'esprit négro-africain, peutêtre sera-t-il lâché par la critique occidentale! Peut-être perdra-t-il l'accès aux prix littéraires auxquels on l'a déjà habitué, et qui le pousse de manière insidieuse à s'assimiler, à se "prostituer" ]. (MAKOUTA-MBOUKOU, 1980. op. cit., p. 204). 
mítica encontram um suporte no conhecimento prévio dos ouvintes: os primeiros requisitam a memória histórica enquanto os segundos trazem à cena ancestrais míticos. Essa restituição de um passado é amplamente respaldada pela longa genealogia do herói, que é recuperada pelo griot ao início de cada narrativa heróica.

O romance histórico não abandona essa característica da narrativa tradicional. Em Soundjata ou l'épopée du Manding (NIANE 1960), o griot Djeli Mamadou Kouyaté apresenta sua própria genealogia e enaltece os dons dos Kouyaté, para quem a "arte de falar não tem nenhum segredo"; em seguida, traça a genealogia de seu herói histórico:

Écoutez donc, fils du Manding, enfants du peuple noir, écoutez ma parole, je vais vous entretenir de Soundjata, le père du Clair-Pays, du pays de la savane, l'ancêtre de ceux qui tendent les arcs, le maître de cent rois vaincus.

Je vais parler de Soundjata, Manding-Diara, lion du Manding, Sogolon Djata, fils de Sogolon, Nare Maghan Djata, fils de Nare Maghan, Sogo Sogo Simbon Salaba, héros aux noms multiples.

Je vais vous parler de Soundjata, celui dont les explois étonneront longtemps encore les hommes. Il fut grand parmi les rois, il fut incomparable parmi les hommes; il fut aimé de Dieu car il était le dernier des grands conquérants. ${ }^{107}$

Como observa, Amadou Koné,

O griot narrador não apenas fala de si mesmo e de sua arte, mas também desenvolve a função conativa da linguagem que mistura à função fática, mantendo sempre o contato com o público que o escuta. ${ }^{108}$

Tal observação, além de corroborar com a função didática da narrativa tradicional, demonstra ainda o grau de empenho do griot em obter o assentimento do público, ligando seu herói a fontes sólidas para que o público possa servir como testemunha da veracidade e exatidão do conteúdo da

107 NIANE, Djibril T., 1960, op. cit., p. 12.

${ }^{108}$ Non seulement le griot narrateur parle de lui-même et de son art mais il développe aussi la fonction conative du langage qu'il mêle à la fonction phatique, en maintenant toujours le contact avec le public qui l'écoute. (KONÉ, Amadou, 1985, op. cit., p. 53). 
narrativa. Este é, de fato, um meio de garantir que seu relato seja coerente e fidedigno, mas não deixa de atender a uma certa vaidade pela exibição de seus talentos. Segundo Christiane Seydou:

A epopéia é marcada pelo selo do teatro tanto quanto pela narrativa propriamente dita. Nela reconhecemos uma exploração judiciosa da técnica teatral, da técnica do conto e da narrativa, habilmente condicionados: diálogos que alternam com a narração, quadros com comentários pessoais do narrador que, com um ditado, uma sentença, pontua tal cena ou tal proclamação; o desenvolvimento geral segue, entretanto, uma progressão dramática perfeitamente elaborada. ${ }^{109}$

Esse recurso às técnicas teatrais observadas por Seydou, as intervenções do narrador com seus comentários e a interação permanente com o público formam um conjunto de procedimentos estreitamente ligados à oralidade das narrativas. O narrador tradicional não deixava de considerar o papel que o público desempenhava no desenvolvimento da intriga. O público da África tradicional não era apenas um público consumidor e sua atuação se aproxima daquilo que conhecemos como teatro interativo, exceto pelo caráter de "guardião"110 da obra recitada pelo narrador. A força do público tradicional também ultrapassa o que é conhecido, no teatro ocidental, como interatividade da platéia; este público pode não apenas participar, por meio de perguntas lançadas ao narrador, mas pode ainda levá-lo a reconsiderar e a retomar a narrativa, sendo, portanto, uma espécie de sensor que observa a fidedignidade do texto com relação ao modelo original. A tradição oral partia de uma espécie de roteiro pré-estabelecido no qual os personagens, os conflitos e a ação mantinham-se inalterados. Embora a criação não estivesse totalmente excluída

${ }^{109}$ L'épopée est marquée au sceau du théâtre tout autant que du récit proprement dit. On y reconnaît une exploitation judicieuse de la technique théâtrale et celle du conte, du récit habillement conditionnés: dialogues alternant avec narration, tableaux avec commentaires personnels du narrateur qui, d'un dicton, d'une sentence, ponctue telle scène ou telle proclamation; le tout suit néanmoins une progression dramatique parfaitement élaborée. (SEYDOU, Christiane apud KONÉ, Amadou, 1985, idem, p. 52$53)$.

110 O termo "guardião" se refere ao controle que o público exercia sobre a fidelidade da narrativa aos fatos e à biografia dos heróis. 
da África tradicional - como prova a própria existência desses roteiros que foram, um dia, criados por algum artista -, a importância atribuída ao grupo fazia com que o autor mantivesse seu anonimato e a criatividade dos narradores permanecesse no nível de sua linguagem e de seu estilo. Tal observação reserva-se, entretanto, à narrativa épica, considerada uma narrativa profana em comparação com a narrativa iniciática, que devia respeitar um ritual e um discurso rigoroso. É importante lembrar que enquanto a narrativa épica traduz uma luta pela expansão ou reconquista de um poder, cuja legitimidade é garantida pela determinação do destino, a narrativa iniciática é orientada pelas leis visíveis e invisíveis que regem o mundo. Enquanto os símbolos são explicados na narrativa guerreira, no texto iniciático é preciso decifrá-los; daí a necessidade de que a água da vida penetre o grão, para que a germinação do discurso possa ocorrer ${ }^{111}$. É por essa razão que a narrativa iniciática utiliza uma linguagem imagética, cujo significado profundo só será revelado por meio da atuação afetiva dos aspirantes à initium novae vitae.

Seguindo uma linguagem mais clara e acessível, a narrativa heróica descreve os grandes feitos daqueles que governam o mundo, que atuam politicamente de modo a estabelecer, manter e fazer prosperar os grandes reinos. Esse constitui o principal interesse do público profano: deleitar-se e instruir-se por meio das descrições das batalhas, dos obstáculos vencidos, dos episódios nos quais o herói sobrepuja os inimigos, visíveis ou invisíveis, e reconquista sua honra espoliada. É por essa razão que, nessas narrativas, as longas descrições de episódios edificantes são mais abundantes que os raros e sumários diálogos.

Se os diálogos da narrativa heróica possuem uma extensão reduzida e ocupam uma parte relativamente pequena da narrativa, eles não deixam de

${ }^{111}$ Il faut que l'eau de ta vie pénètre en la graine/ Pour que la germination de la parole ait lieu (CAMARA, Sory, op. cit., p. 8). 
ter uma função do ponto de vista dramático. Em Soundjata ${ }^{112}$, por exemplo, o diálogo mais longo, que se dá entre os reis, ${ }^{113}$ contribui para a progressão da narrativa, pois anuncia o combate entre Soundjata e Soumaoro e constitui um enfrentamento verbal cuja carga semântica anuncia a vitória de Soundjata.

Uma das atribuições do griot-personagem é expor uma situação a fim de persuadir e incitar o herói ao combate. Além da presença de diálogos que instruem o público a respeito das razões profundas dos conflitos, os monólogos surgem como longos discursos de exortação do herói à ação.

\subsection{Do romance histórico ao romance moderno: alterações e exigências da recepção}

Como vimos anteriormente, as fontes da narrativa tradicional eram retiradas da História tradicional. No caso dos romances históricos, os temas mantêm ainda a mesma proveniência, mas podem versar sobre uma história

112 Soundjata: "A epopéia mandingue" segue a progressão da realização do destino de Soundjata predito pelo caçador divino. A narrativa pode facilmente ser recortada em quadros sucessivos: a chegada da mulher búfalo, a noite da concepção da criança, seu nascimento, sua paralisia e sua cura, suas façanhas de simbon, seu exílio, as façanhas guerreiras junto ao rei de Nama, o retorno do exílio e o combate vitorioso contra Soumaoro, etc. Segundo a História, Soundjata conheceu o exílio: as cidades das quais falam os griots existiram ou existem ainda; a grande batalha de Krina aconteceu. $\mathrm{Na}$ realidade, o maravilhoso vem da manifestação do sobrenatural em torno de fatos importantes como o nascimento de Soundjata ou os grandes feitos guerreiros.

${ }^{113}$ Voici le dialogue des rois-sorciers: - Arrête, jeune homme. Je suis désormas roi du Manding; si tu veux la paix, retourne d'où tu viens, dit Soumaoro. / - Je reviens, Soumaoro, pour reprendre mon royaume. Si tu veux la paix tu dédommageras mes alliés et tu retourneras à Sosso, où tu es roi. / - Je suis roi du Manding par la force des armes; mes droits ont été établis par la conquête. / - Alors je vais t'enlever le Manding par la force des armes, je vais te chasser de mon royaume. / - Apprends donc que suis l'igname sauvage des rochers, rien ne me fera sortir du Manding. / - Sache aussi que j'ai dans mon champ sept maîtres forgerons qui feront éclater les rochers ; alors, igname, je te mangerai. / - Je suis le champignon vénéneux qui fait vomir l'intrépide. / - Moi, je suis un coq affamé, le poison ne me fait rien. / - Sois sage, petit garçon, tu te brûleras le pied car je suis la cendre ardente. / - Moi, je suis la pluie qui éteint la cendre, je suis le torrent impétueux qui t'emportera. [...] - Prépare-toi, Soumaoro, car le mal qui va s'abattre sur toi et les tiens ne finira pas de sitôt. / Ainsi Soundjata et Soumaoro ont parlé. Après la guerre des bouches, les sabres devaient donner les conclusions. (NIANE, 1960, op. cit., p. 111-113). 
mais recente. A diferença no tratamento dessas narrativas refere-se, sobretudo, às técnicas e à maior participação do autor, cuja expressão encontra uma liberdade que o griot não possuía. Tal liberdade origina-se de duas razões fundamentais: em primeiro lugar, o contato do escritor com a cultura ocidental, estabelecido, sobretudo, por sua educação formal e pela influência do romance ocidental, foi responsável pelo trabalho intenso da imaginação que não fazia parte da narrativa tradicional; em segundo, o escritor, pela própria natureza da matéria prima de seu ofício, não está mais submetido à intervenção imediata do público. No entanto, mesmo estando de posse de recursos que o autorizam a criar mais livremente, o escritor do romance histórico mantém uma progressão muito próxima da narrativa tradicional. A ação se desenvolve por meio da exposição de quadros sucessivos que descrevem, em geral, a genealogia do herói, as cenas de predição dos oráculos e sua realização, alcançada por meio de episódios nos quais as lutas e os enfrentamentos legitimam a vitória. Como afirma Amadou Koné, o que parece interessar os romancistas - como, outrora, o griot - é a exposição da vida sob todas as formas nas sociedades onde se desenrola a narrativa. ${ }^{114}$

A esse interesse comum em expor a vida na sociedade tradicional ${ }^{115}$, é preciso acrescentar as distinções entre uma e outra exposição. Enquanto na narrativa tradicional o griot tinha o objetivo de situar historicamente seus personagens, expor as razões dos conflitos ou enaltecer os atributos do herói e a legitimidade de suas reivindicações, na narrativa histórica, além de situar geográfica e politicamente seus personagens e ação, os autores tinham consciência de que seu público ocidental desconhecia a sociedade por eles descrita e, além disso, o preconceito disseminado na Europa com relação aos

114 Ce qui semble intéresser les romancier - comme le griot naguère -, c'est l'exposition de la vie sous toutes ses formes dans les sociétés où se passe le récit. (KONÉ, Amadou, op. cit., 1985, p. 83).

${ }^{115}$ Cf. Análise de Amadou Koné (1985, p. 83-89) referente aos romances históricos, sobretudo, Doguicimi, de Paul Hazoumé, e Crépuscule des temps anciens, de Nazi Boni, dos quais é possível inferir o cuidado dos autores em explicar os costumes descritos, uma vez que grande parte de seus leitores é ocidental. 
ritos e costumes africanos exigia a inserção de longas explicações. É por essa razão que as descrições se tornam mais precisas.

À medida que os contornos mais precisos com relação aos dados culturais da sociedade africana se faziam necessários, aumentava também a exigência ao se tratar de personagens da tradição. Assim, sob a influência ocidental e obedecendo a essa necessidade de rigor de informações quase etnológicas, os caracteres também se tornaram mais complexos.

Com o surgimento da complexidade dos perfis, da profundidade psicológica e dos conflitos internos, os diálogos começam a ter maior importância, pois a interatividade que ocorre na comunicação deixa transparecer o tratamento que o herói dá às suas questões existenciais e à maneira como ele as coloca diante do mundo. O confronto que surge desse tipo de esquema comunicacional expõe os aspectos constitutivos dos personagens e obriga-os a um exercício dialético do qual é possível extrair os pensamentos divergentes. Mas a amplificação da dialogia, de certo modo, não deixa de debilitar o herói, já que ele não mais se encontra respaldado por um esquema a ser seguido, o que o leva a lidar com o dado bruto dos conflitos sem o respaldo dos modelos tradicionais.

A alteração do esquema tradicional de comunicação ${ }^{116}$ não se estende, entretanto, a todos os procedimentos da narrativa e de sua exposição ao público. O escritor da narrativa histórica e, posteriormente, do romance moderno, não deixa de fazer referencia à narrativa oral: a freqüente interpelação ao público feita pelo griot transforma-se então na interpelação, também freqüente, ao leitor ou, ainda, na alusão a uma platéia imaginária.

De um modo geral, essa primeira fase do romance africano retoma alguns procedimentos da narrativa tradicional. Os textos se iniciam com a

\footnotetext{
${ }^{116}$ Referimo-nos aqui à alteração formal do romance, ou seja, ao aumento da presença dos diálogos no interior da narrativa. Um estudo sobre o esquema comunicacional da tradição foi elaborado por Amadou Koné (1985, p. 26) que, em comparação ao modelo saussuriano, estabelece as condições de emissão e recepção da mensagem na narrativa oral africana. Neste caso, a diferença entre as narrativas tradicional e moderna encontra-se na inserção de um segundo emissor: um agente rítmico que tem a dupla função de emitir a mensagem e representar o público.
} 
genealogia do herói, são dispostos em quadros que evoluem cronologicamente $^{117}$ e a estrutura social da tradição é uma presença relativamente constante, com a diferença de que, nesta fase, as descrições geopolíticas se tornaram quase um imperativo.

O moderno romance africano também conserva grande parte da estrutura formal das narrativas tradicionais: apresenta um desenvolvimento linear que se inicia com o nascimento do herói, percorre seu crescimento, suas ações e desafios, até chegar ao desfecho que, agora, tanto pode ser a vitória quanto uma grande derrota. É importante lembrar que a existência do romance moderno africano se deve ao contato com a cultura européia, que por sua vez, tornou-se presença constante nos romances como fonte temática.

Além dos elementos da estrutura formal, o romance moderno mantém ainda a presença das predições e dos sonhos que estão intimamente ligados à ação como determinações de um destino pré-estabelecido. Trata-se, em geral, de formulações enigmáticas que direcionam o efeito das ações e os desfechos da narrativa. Em Soundjata, por exemplo, o griot acaba por solicitar o esclarecimento das obscuras palavras do adivinho:

Le devin revint à ses cauris.

D'une main habile il les fit jouer dans sa paume et les jeta.

- Roi du Manding, le destin marche à grands pas, le Manding va sortir de la nuit, Nianiba s'illumine, mais quelle est cette lumière qui vient de I'Est ?

- Chasseur, fit Gnankouman Doua, tes paroles sont obscures, rendsnous accessible ton langage, parle la langue claire de ta savane ${ }^{118}$.

- J'arrive griot. Écoutez mon message. Écoute roi.

"Tu as regné sur le royaume que t'ont legué tes ancêtres, tu n'as pas d'autres ambitions que de transmettre ce royaume intact sinon agrandi à tes descendants; mais Beau Maghan ton héritier n'est pas encore né.

117 Embora mantenham uma relativa independência uns com relação ao outros. Cf página 72 deste capítulo, no qual abordamos a independência dos tali, que formam o desenvolvimento das Paroles très anciennes, recolhidas por Camara Sory.

$118 \mathrm{O}$ autor esclarece em nota de rodapé: A língua clara por excelência é o Malinké. Para os Malinkés, sua língua é clara como a região em que vivem, que gostam de opor, com freqüência, à floresta, região obscura. [La langue claire par excellence c'est le Malinké. Pour les Malinkés leur langue est claire comme leur pays, qu'ils aiment souvent opposer à la forêt, pays sombre]. (NIANE, Djibril T., 1960, op. cit., p. 20). 
"Je vois venir vers ta ville deux chasseurs; ils viennent de loin et une femme les accompagne. Oh, cette femme! Elle est laide, elle est affreuse. Elle porte sur son dos une bosse qui la déforme, ses yeux exorbitants semblent posés sur son visage, mais, ô mystère des mystères, cette femme, roi, tu dois l'épouser car elle sera la mère de celui qui rendra le nom de Manding imortel à jamais, l'enfant sera le septième astre, le Septième Conquérant de la terre, il sera plus puissant que Djoulou Kara Naïni. Mais roi, pour que le destin conduise cette femme jusqu'à toi, un sacrifice est nécessaire : tu immoleras un taureau rouge car le taureau est puissant; quand son sang imbibera la terre, rien ne s'opposera plus à l'arrivée de ta femme. Voilà, j'ai dit ce que $j^{\prime}$ avais à dire, mais tout est entre les mains du Tout-Puissant. ${ }^{119}$

Em Les soleils des Indépendances, a predição, ainda mais enigmática do que a de Soundjata, é feita sob a forma de uma metáfora cuja extensão semântica só será afetivamente apreendida após o contato de Fama com a capital da Côte des Ébènes:

Bakary ${ }^{120}$ s'en alla consulter, prier, adorer Allah et les ancêtres. Une nuit une voix s'exclama :

- Merci Bakary! Merci des offrandes! Prends la puissance! Les lois ne se démentiront pas, mais à cause de ta piété on fera des accomodements. Ta descendance coulera, faiblira, séchera jusqu'à disparaître, comme les puissants courants qui se déversent de la montagne grossissent, puis faiblissent et meurent dans la vallée sablonneuse et désertique, loin de la mer et des fleuves.

- Je renonce à la puissance, répondit Bakary refroidit.

- Prends-la. La fin de ta descendance n'arrivera ni demain, ni aprèsdemain, ni un jour prochain. Il se fera un jour où le soleil ne se couchera pas, où des fils d'esclaves, des bâtards lieront toutes les provinces avec des fils, des bandes et du vent, et commanderont, où tout sera pleutre, éhonté, où les familles seront...

- Oui ! Oui ! Merci, j'ai compris, s'écria Bakary inspiré; ma descendance disparaîtra le jour du jugement dernier.

Et Bakary s'arrogea le pouvoir sur toutes les opulentes provinces, toutes les terres du Horodougou. Le Horodougou qui fut démembré et appartenait désormais à deux républiques, les Doumbouya en furent les chefs honorés. Dommage! Dommage que l'aïeul Bakary n'ait pas attendu, n'ait pas tout écouté. La voix aurait continué de décrire le jour de la fin de la dynastie Doumbouya. Fama avait peur. Comme authentique descendant il ne restait que lui, un homme stérile vivant

119 NIANE, Djibril T., 1960, idem, p. 19-20.

120 Descendente de Souleymane Doumbouya que herdou o Horodougou das mãos dos conquistadores Malinkés muçulmanos do Norte, um reinado que deveria pertencer aos autóctones Bambaras. Confuso, Bakary consulta Alá e os ancestrais a fim de assegurar-se da legitimidade de tal oferta. 
d'aumônes dans une ville où le soleil ne se couche pas (les lampes électriques éclairant toute la nuit dans la capitale), où les fils d'esclaves et les bâtards commandent, triomphent, en liant les provinces par des fils (le téléphone!), des bandes (les routes!) et le vent (les discours de la radio !). Fama eut peur de la nuit, du voyage, des funérailles, de Togobala, de Salimata, de Mariam, de lui-même. Peur de sa peur. ${ }^{121}$ ( $\mathrm{p}$. 99-100)

A distância que separa o romance histórico do romance moderno permite não apenas a alteração formal das predições, mas também as condições de recepção e reação do próprio herói frente ao conteúdo da mensagem. Em Soundjata, observamos o vaticínio do oráculo que prevê um grande destino para Beau Maghan, futuro herdeiro do Manding; em Les soleils des Indépendances, além do fortalecimento temporário da descendência de Bakary obtida graças à sua devoção a Alá e aos ancestrais, o oráculo anuncia a queda e desaparecimento da dinastia Doumbouya. Enquanto Gnankouman Doua pede esclarecimento sobre as obscuras palavras do adivinho de Soundjata, Bakary interrompe as previsões da voz que previa o fim da dinastia Doumbouya. Tal interrupção simboliza, de certo modo, uma ruptura que se estabelece em vários níveis: a previsão favorável foi substituída pela previsão funesta; a solicitação de esclarecimento deu lugar à pretensão de Bakary de ter compreendido a mensagem do oráculo antes mesmo que esta tivesse sido concluída; e, em termos formais, o oráculo de Kourouma rompe com o padrão das previsões da narrativa tradicional, trazendo-o para o conhecimento do leitor sob a forma de flash back e não como era anunciado na tradição, ou seja, como um dos primeiros dados que antecipavam o caminho a ser percorrido pelo herói e definiam a seqüência lógica de previsão e sua posterior realização. Podemos acrescentar ainda como uma variante do modelo tradicional na previsão feita a Bakary o retardamento da compreensão total das palavras do oráculo. O equívoco na recepção da mensagem passou, provavelmente, de geração em geração até chegar em Fama, que pôde enfim desvendar o significado profundo das previsões. Tal qual o indivíduo que se

${ }^{121}$ KOUROUMA, LsdI, op. cit., p. 99-100. 
submete à viagem iniciática, Fama precisou deixar o Horodougou, viver na capital e ampliar suas experiências para que pudesse, enfim, ter elementos suficientes que lhe permitissem entender o sentido oculto das palavras. Uma lástima que sua viagem não o tenha conduzido a nenhuma elevação e realização plena do indivíduo, mas à constatação do fim iminente que justifica a profundidade e extensão de seu medo.

Assim como a utilização do flash back, um recurso relativamente moderno para o padrão da narrativa africana, outras inserções e/ou adaptações foram feitas na medida em que o público ouvinte foi substituído pelo leitor. Os procedimentos narrativos tradicionais só podem persistir na medida em o novo veículo de transmissão o permite. Longe do alcance imediato de seu público, o escritor adquire maior liberdade de criação, pois não mais se encontra frente ao censor que corrigia os desvios dos modelos históricos narrados pelo griot. No que diz respeito à forma, supressões como a presença do canto que, por vezes, exercia a função de sentença normativa para os heróis tradicionais, foram substituídas pelo ritmo subjacente à freqüência dos provérbios na narrativa escrita. Freqüentes no texto tradicional, os provérbios absorveram em parte a função do canto e passaram então a exercer a dupla função de veicular a sabedoria popular e cadenciar a intriga. Se o novo veículo de criação permitiu essa passagem do griot narrador ao escritor criador, abrindo espaço para uma atuação do imaginário inconcebível na tradição oral, o romancista africano não deixa por isso de manter as características da narrativa tradicional. Aliás, é preciso lembrar que o mérito da atuação do griot não pode ser avaliado pela atuação do imaginário, mas pelo talento na execução da narrativa. Talvez aqui caiba comparação de uma das principais atividades do griot com a análise que Borges (2000, p. 55) fez da narrativa épica: Não acho que as pessoas fossem menos criativas naquela época do que são hoje. Acho que sentiam que as nuances introduzidas na história - as sutis nuances nela introduzidas - bastavam. Numa outra fase das literaturas africanas, na qual as nuances da história já não eram suficientes para o público leitor, a imaginação do escritor adquire maior importância, mas 
nem por isso suprime as características que herdou da tradição. Embora os escritores sejam forçados a utilizar ferramentas lingüísticas que não forjaram, a inserir suas criações em moldes que não inventaram (CONDÉ 1977, p. 13) alguns romances se aproximam da estrutura da narrativa tradicional, introduzindo a genealogia, as anedotas, os contos, mitos ou lendas que evocam a tradição, ou ainda, inserindo explicações metafísicas como um traço distintivo da sociedade africana em oposição ao racionalismo europeu, sobretudo ao cartesianismo francês.

\subsection{Função da narrativa: do etos da tradição ao etos da sociedade híbrida}

A literatura oral não pode ser dissociada das atividades cotidianas do homem africano e uma de suas principais funções consiste em instruir, transmitindo o conhecimento e educando pelo exemplo. Um sistema eficaz da educação tradicional que, ao lado da lição domiciliar ${ }^{122}$, privilegiava o modelo e as virtudes dos grandes heróis. Além do entretenimento, os elementos que compunham a base da narrativa dos griots também exerciam uma função pedagógica de amplo espectro: transmitiam a todos um modelo acabado de conduta em contraposição ao que ocorria na narrativa iniciática cuja compreensão do sentido profundo exigia reflexão e experiência de um número restrito de indivíduos. Sabemos que a fonte da narrativa épica tradicional tem sua origem na História, mas, independente do recorte sobre o qual se desenvolve a narrativa, sua função permanece a mesma:

\footnotetext{
122 NOKAN, Charles. Charles Nokan: Depoimento [mar. 2006]. Entrevistadora: Maria Suzana Moreira do Carmo. Abidjan, 2006. 1 fita cassete (60 min). Cf. Anexo I desta pesquisa.
} 
Toda epopéia nasce de um passado prestigioso ${ }^{123}$, com a intenção de despertar o nacionalismo em cada indivíduo, de manter ou ressuscitar valores altamente apreciados, que são um testemunho deste brilho do passado. A narrativa heróica guerreira enaltece este passado e não se priva de recorrer ao maravilhoso para enriquecer os personagens e ampliar a ação. O narrador deixa entender, de imediato, que a história que está sendo narrada é uma verdade fundamental que é preciso conhecer para que seja possível compreender o processo evolutivo do mundo. ${ }^{124}$

Djeli Mamadou Kouyaté, griot de Soundjata, lembra a todos em sua apresentação: J'ai enseigné à des rois l'Histoire de leurs ancêtres afin que la vie des Anciens leur serve d'exemple, car le monde est vieux, mais l'avenir sort du passé. ${ }^{125}$

É nesse sentido que tanto o griot narrador quanto o griot personagem atuam: "ilustram" na dupla apreensão do termo, ou seja, exemplificam e instruem. A narrativa dos griots enfatiza, portanto, o espírito da tradição de modo a veicular os princípios que justificam a ordem estabelecida, apresentando modelos cujas características devem ser admiradas e, se

${ }^{123}$ Amadou Koné faz um longo estudo a respeito da gênese do romance histórico no qual analisa Soundjata ou l'épopée du Mandingue, de Djibril Tansir Niane, Paris Dakar: Éditions Présence Africaine, 1960 (meados do século XIII, quando Soundjata reina depois de ter derrotado o rei do Sosso, Soumaoro Kanté); Da Monzon de Segou, épopée bambara, de Lilian Kesteloot, Paris: Fernand Nathan, 1972, 4 tomos (reinados de Ngolo Diara e de Da Monzon entre 1710 e 1827); e Silâmaka et Poullôri, un chant épique peul, editado por Christiane Seydou, Paris: Julliard, Coll. Classiques africains, 1973 (luta dos chefes Peuls, do final do século XVIII ao inicio do XIX, contra a autoridade do reino bambara antes da constituição, por Cheikou Amadou, do Império peul do Massina).Segundo Koné: Os três reinos ou impérios tratados nessas narrativas se situam na mesma região. Trata-se desses reinos que conheceram, cada um a seu tempo, sua era de glória no delta do Niger e que, excetuando-se o reino de Segou, foram fortemente influenciados pelo Islã. [Les trois royaumes ou empires dont parlent ces récits se situent tous dans la même région. Il s'agit de ces royaumes qui chacun à son tour ont connu leur ère de gloire dans la boucle du Niger et qui ont été, à l'exception du royaume de Segou, fortement influencés par l'islam.]. (KONÉ, Amadou, op. cit., 1985, p. 58).

124 Toute épopée naît d'un passe prestigieux, avec l'intention de réveiller le nationalisme en chaque individu, de maintenir ou ressusciter des valeurs hautement appréciées qui sont un témoignage de cet éclat du passé. Le récit héroïque guerrier magnifie ce passé et ne prive pas de recourir au merveilleux pour embellir les personnages, grossir l'action. Le narrateur du récit fait comprendre tout de suite que I'histoire qu'il raconte est une vérité fondamentale qu'il est nécessaire de savoir pour comprendre la marche du monde. (KONÉ, Amadou, 1985, op. cit., p. 59).

125 NIANE, Djibril T., 1960, op. cit., p. 10. 
possível, imitadas. Assim, a narrativa tradicional se dirige ao conjunto da sociedade de modo a conquistar a voluntária adesão dos ouvintes à sua ideologia. Naturalmente, na base dessa ideologia encontra-se o assentamento de uma estratificação social na qual os papéis estão absolutamente definidos e onde cada um encontra o seu lugar. Dentro de uma perspectiva marxista, que, para muitos, serviu de apoio à luta e à reivindicação da resistência africana à invasão colonialista, poder-se-ia questionar o emprego da arte, neste caso, da narrativa oral, como veículo de reforço de uma ideologia das elites, mas tal interpretação constituiria, a nosso ver, um equívoco epistemológico, pois negligenciaria o fato de que a sociedade tradicional africana não comporta a luta de classes e suas guerras e batalhas se dirigem à expansão territorial ou às disputas étnicas.

Quando Amadou Koné (1985) ressalta o atributo pedagógico da narrativa heróica épica, não deixa de sublinhar o fato de que, sozinha, não é capaz de manter a coerência da sociedade tradicional e velar pela coesão ancestral que reforça o império, o reino ou a tribo a fim de manter-se forte o suficiente para dominar os demais. Assim, a narrativa heróica recebe o apoio das demais formas literárias, dentre as quais a narrativa iniciática, pois aquele que se submete à iniciação respeita os valores tradicionais e se submete com rigor ao conhecimento adquirido ${ }^{126}$. A narrativa iniciática não é apenas educativa, mas também coercitiva. Portanto, ambas possuem o objetivo de educar o povo, o agrupamento étnico, em torno de valores que reforçam a ideologia da classe dominante e mantêm a coesão da sociedade tradicional. Dentro desses valores, inscreve-se a estabilidade da ordem espiritual caucionada pela experiência iniciática, que, por sua vez, contribui para a concepção de heróis da narrativa épica tradicional. O herói épico distingue-se do cidadão comum pela aquisição de dons excepcionais ou pela posse de um

${ }^{126} \mathrm{O}$ iniciado peul - silatigi - é uma espécie de sacerdote da comunidade e não tem nenhum interesse em modificar as leis da iniciação, pois os atributos adquiridos com essa condição Ihe conferem prestígio, influência e muitos privilégios. Hammadi, o iniciado de Amadou Hampaté Bâ em Kaïdara, adquire não apenas o conhecimento, mas também a riqueza material. 
destino singular e prestigioso. Uma certa distinção é, portanto, o ponto em comum entre o herói épico e o iniciado, e ambos colaboram para a manutenção do status quo da sociedade tradicional.

No romance histórico, ainda que o imaginário do autor seja tributário da narrativa tradicional, o autor desvincula-se da função educativa imediata até então exercida pelo griot. Dentro de um novo contexto, ou seja, a situação de colonizado, o escritor africano recorre aos personagens autênticos da História do continente, mas a elaboração do texto, os perfis, a intriga e o desfecho dependem, a partir de então, de sua habilidade criativa. Como representante de uma primeira fase de mutação da narrativa tradicional, o romance histórico acrescenta aos elementos da tradição o suporte escrito e, conseqüentemente, uma estética importada; um gênero híbrido representando uma sociedade igualmente fracionada. De uma narrativa que visava a integridade e a coesão de um grupo, passou-se então a romances que, de certo modo, desempenharam o papel de documento etnológico como meio de preservar e enaltecer a memória já então desacreditada da tradição. Não se tratava mais de um ensinamento a ser posto em prática, mas, antes, do balanço de algo que está condenado a morrer. ${ }^{127}$ As escolhas dos escritores não fazem senão corroborar o temor dessa morte que abre espaço para a permanência dos princípios que guiam a sociedade moderna trazida com o colonialismo.

As narrativas modernas, cuja produção desvinculou-se da exaltação de heróis de prestígio, contam agora com a epopéia de homens inseridos na realidade imediata como fonte de inspiração. Segundo Gnaoulé-Oupoh (2000, p. 289), tal inspiração ocorre a partir de 1968 como resultado de uma necessidade de contemplar a nova situação criada pelas independências africanas. Essa datação poderia, no entanto, nos levar a considerar a produção romanesca anterior a este marco como tendo outra fonte de inspiração que não fosse a realidade imediata, o que de fato não ocorreu. O romance, as narrativas de viagem ou autobiográficas inspiravam-se também da realidade e

127 ... un enseignement à mettre en pratique mais plutôt le bilan de quelque chose qui est condamné à mourir. (KONÉ, Amadou, 1985, idem, p. 93). 
a diferença parece consistir no tratamento dado ao tema, ou seja, de uma escrita menos comprometida com ideais libertários passou-se a um engajamento fundamental para a constituição da identidade africana. O que Gnaoulé-Oupoh (2000, p. 289-328) considera como marco de uma literatura mais comprometida com a realidade imediata corresponde, de fato, ao que foi considerado pela crítica como o momento do desencanto com o processo de independência ou, como assinala Pius Nkashama, o período que se estende da cultura colonial aos rancores das ditaduras militares ${ }^{128}$ dos anos 1966-1970 ${ }^{129}$, quando não restava mais dúvida sobre o malogro dessa virada política. 0 ano de 1968 assinala a primeira publicação de Les soleils des Indépendances, romance cuja recepção favorável da crítica africana ratifica uma mudança que já se havia insinuado em 1966, com Charles Nokan, em Violent était le vent ${ }^{130}$. O que outrora constituía o uso da palavra como fonte de sabedoria e meio eficaz de educação, controle e coesão de grupos sociais, tornou-se instrumento que revela a percepção e a ideologia individual do autor, que pode estender-se da crítica ao sistema sócio-político à incitação à luta e à revolução. A palavra deixou, portanto, de ser um meio de aquisição de conhecimento para tornar-se o reflexo de uma realidade na qual as incertezas são majoradas pela falta de modelos ideais. Os antigos heróis não têm mais nenhuma função dentro do contexto de hibridização das sociedades africanas ex-colonizadas. Nokia, protagonista de Violent était le vent, retrata a nova ordem social: formado na França, retorna a seu país de origem com a imagem clara da mudança da paisagem humana e da banalização de seus sonhos de desempenhar um papel

\footnotetext{
128 Grifo do autor.

129 ... [celui] qui va de la culture coloniale aux rancoeurs des dictatures militaires des années 1966-1970. (NGANDU NKASHAMA, Pius. Ruptures et écritures de violence : Études sur le roman et les littératures africaines contemporaines. Paris: Harmattan, 1997. p. 96).

130 Publicado dois anos antes do primeiro romance de Ahmadou Kourouma, Violent était le vent é considerado pela crítica uma obra de transição na história da literatura marfinense. Embora permaneça ligado aos temas dos romances produzidos na Costa do Marfim até 1965, Charles Nokan dá uma dimensão política ao seu protagonista até então desconhecida - Nokia, um estudante que durante sua formação na França adquire uma consciência política que o leva a lutar contra o neocolonialismo em seu país.
} 
importante na melhoria da qualidade de vida de seu povo e na construção de um mundo pacífico: L'image poétique que j'avais gardée de mon Afrique mourait. ${ }^{131}$ Sua consciência havia adquirido a dimensão exata de uma irreversibilidade apenas pressentida na infância:

Il y avait peu de temps, le garçon exemplaire, c'était celui qui suivait partout son grand-père, lequel lui enseignait les secrets de la vie, les rites, l'art de conter, c'était aussi celui dont le beau corps musclé annoncait un guerrier héroïque. L'éducation, toute empirique, ne manquait pas de procurer la joie à tous. [...] Il nous fallait maintenant fréquenter l'école ennuyeuse. Notre intelligence se mouvait dans un monde étranger, inconnu. [...] Avec lui [le grand-père] et des sorciers, j'ai appris la cosmogonie de ma tribu. Il me coûtait à présent de voir I'Univers avec des yeux nouveaux. ${ }^{132}$

Embora o olhar da criança retrate uma certa idealização da cultura, tal resgate é feito sob o signo da morte da tradição, uma destruição que Ahmadou Kourouma retrataria em Les soleils des Indépendances como o desmoronamento do modelo tradicional, a ponto de permitir-se a ridicularização de seu protagonista: Fama, o príncipe nascido e criado pour préférer l'or à l'or ${ }^{133}$, encontra na mendicância seu único meio de sobrevivência; além disso, o último herdeiro dos Doumbouya exibe uma fraqueza de caráter intolerável na tradição porque despojada de qualquer preocupação com o grupo. Se ele resiste à colonização é porque foi privado de seus bens e privilégios; se luta contra as Independências é porque ela não devolveu o que the foi usurpado. Um pouco menos alusiva do que a morte anunciada pelo menino Nokia, forçado a enxergar o mundo com outros olhos, a morte de Fama ao final do romance torna-se a metáfora da inelutável desintegração de uma parte da História do continente africano.

Ao etos da tradição substituiu-se o etos da sociedade híbrida, retratada nos romances como uma sociedade cujo desenvolvimento se dirige, cada vez mais, a posicionamentos individuais.

\footnotetext{
${ }^{131}$ NOKAN, Charles. Violent était le vent. Paris : Présence Africaine, 1966. p. 58.

132 NOKAN, 1966, ibidem, p. 27-28.

133 KOUROUMA, LsdI, op. cit., p. 12.
} 
Ainda que a narrativa tradicional se desloque, cada vez mais, para o terreno das reminiscências e que a lembrança da literatura oral nem sempre marque a literatura escrita com o vigor que desejaríamos, Les Soleils des indépendances, de Ahmadou Kourouma, continua sendo uma das poucas obras que, decididamente, escapam a essa regra ${ }^{134}$, pois, como aponta Maurice Huis:

Estamos diante de um significante, escreve o autor: o texto escrito. Quanto ao significado, ele é duplo; encontra-se aquém e além do texto. Aquém do texto, existe a fonte de criação feita de imaginário e de simbolismo cujas raízes estão na cultura e na semântica de uma língua, ambas experimentadas pelo autor no seio do território malinké. Além do texto, há uma criação proposta aos leitores e também aos ouvintes, pois Les Soleils des indépendances poderia ser proferido. ${ }^{135}$

Esse desenvolvimento da cultura e da extensão semântica que recupera a tradição, mas, ao mesmo tempo, revela o amálgama de processos expressivos distintos e superpostos, será tratado na terceira parte deste trabalho, sob a perspectiva da constituição identitária.

$134 \ldots$ si le souvenir de la littérature orale n'impregne pas toujours, aussi vigoureusement qu'on l'aurait souhaité, l'écrit (...) Un des seuls ouvrages qui échappe résolument à cette règle... CONDÉ, Maryse. La création littéraire en Afrique. In : AZIZA, Mohamed. (Org.). Patrimoine culturel et création contemporaine en Afrique et dans le monde arabe. Dakar: NEA, 1977, p. 13-32.

${ }^{135}$ Nous sommes, écrit-il, face à un signifiant : le texte écrit. Quant au signifié, il est double; il est en deçà et au-delà du texte. En deçà, il y a la source de création, faite d'imaginaire et de symbolisme dont les racines sont dans la culture et la sémantique d'une langue, l'une et l'autre éprouvées par l'auteur au sein du terroir malinké. Audelà, il y a une création proposée aux lecteurs et aussi aux auditeurs, car Les Soleils des Indépendances pourait être proféré. (HUIS apud CONDÉ, 1997, idem, p. 27). 


\section{LES SOLEILS DES INDEPENDANCES: da sociedade sólida ao prelúdio dos laços efêmeros}

C'est au bout de la vieille corde qu'on tisse la nouvelle. Provérbio Minah / Benin.

\section{Dinâmica das identidades}

Tema de distintas e variadas abordagens, a questão da identidade ganhou lugar de destaque nas discussões da modernidade tardia. Como observa Amin Maalouf (1998, p. 15), desde o "Conhece-te a ti mesmo...", de Sócrates, o homem tem tentado entender a identidade como um meio privilegiado de auto-conhecimento ${ }^{136}$. Para Eurídice Figueiredo, ao se partir de uma definição que na sua origem tem um uso ontológico, para empregos cada vez mais fluidos, sem contornos definidos, que vão do sociológico ao antropológico, do político ao cultural, do literário ao existencial, encontram-se problemas que se referem a visões essencialistas e até críticas que negam a possibilidade de se conceber a existência de uma identidade fixa. ${ }^{137}$

Segundo Stuart Hall (2003), o sujeito estável e unificado que caracterizava as "velhas identidades" deu lugar a novas identidades que correspondem à fragmentação do indivíduo moderno:

Um tipo diferente de mudança estrutural está transformando as sociedades modernas no final do século XX. Isso está fragmentando as paisagens culturais de classe, gênero, sexualidade, etnia, raça e

\footnotetext{
${ }^{136} \mathrm{Na}$ verdade, a questão da identidade considerada sob o ponto de vista ontológico já havia sido levantada no período pré-socrático. Heráclito enfatizou sobretudo a idéia de impermanência que subjaz a questão do sujeito. Cf. FERRET, Stéphane. (Introduction, choix de textes, commentaires, vade-mecum et bibliographie). L'identité. Paris: Flammarion, 1998.

137 FIGUEIREDO, Eurídice. (Org.). Conceitos de literatura e cultura. Juiz de Fora: UFJF; Niterói: EdUFF, 2005, p 189.
} 
nacionalidade, que, no passado, nos tinham fornecido sólidas localizações como indivíduos sociais. Estas transformações estão também mudando nossas identidades pessoais, abalando a idéia que temos de nós próprios como sujeitos integrados. ${ }^{138}$

Para Hall (2003, p. 23), três concepções de identidade correspondem à evolução que levou o sujeito da estabilidade à fragmentação, caracterizando as concepções mutantes do sujeito humano: o sujeito do Iluminismo, o sujeito sociológico e o sujeito pós-moderno. A primeira concepção compreende o sujeito que emergiu na idade moderna e fez surgir uma forma de individualismo distinta da experiência individual da era pré-moderna:

As transformações associadas à modernidade libertaram o indivíduo de seus apoios estáveis nas tradições e nas estruturas. Antes se acreditava que essas eram divinamente estabelecidas; não estavam sujeitas, portanto, a mudanças fundamentais. O status, a classificação e a posição de uma pessoa na "grande cadeia do ser" - a ordem secular e divina das coisas - predominavam sobre qualquer sentimento de que a pessoa fosse um indivíduo soberano. O nascimento do "indivíduo soberano", entre o Humanismo Renascentista do século XVI e o Iluminismo do século XVIII, representou uma ruptura importante com o passado. ${ }^{139}$

A concepção de identidade do mundo moderno começa então a adquirir características que, de certo modo, afastam o sujeito da acepção mais elementar do termo: a definição etimológica do subjectus latino, ou seja, aquele que está "submetido a". Submetido a uma determinada configuração sistêmica que, independente de seus parâmetros de organização, atribui ao indivíduo um papel e, portanto, uma função passível de the conferir uma identidade segura e estável.

A segunda concepção de identidade citada por Hall, a do sujeito sociológico, começa a ser elaborada a partir do envolvimento do "indivíduo soberano" com as questões burocráticas e administrativas do estado moderno:

138 HALL, Stuart. A identidade cultural na pós-modernidade. Tradução: Tomaz Tadeu da Silva; Guacira Lopes Louro. 7. ed. Rio de Janeiro: DP\&A, 2003. p. 9.

139 HALL, 2003, idem, p. 25. 
Emergiu então uma concepção mais social do sujeito. O individuo passou a ser visto como mais localizado e "definido" no interior dessas grandes estruturas e formações sustentadoras da sociedade moderna. Dois importantes eventos contribuíram para articular um conjunto mais amplo de fundamentos conceptuais para o sujeito moderno. O primeiro foi a biologia darwiniana. O sujeito humano foi "biologizado" - a razão tinha uma base na Natureza e a mente um "fundamento" no desenvolvimento físico do cérebro humano. O segundo foi o surgimento das novas ciências sociais. ${ }^{140}$

As ciências sociais desempenharam importante papel na interpretação e constituição desta nova identidade, situando o indivíduo dentro dos processos coletivos e fornecendo subsídios para a interpretação das relações entre indivíduo e esferas sociais. Esta nova ligação entre sujeito e coletividade operou uma dupla influência: o homem modificou-se subjetivamente por meio de relações sociais mais amplas e as estruturas organizacionais passaram a contar com a ação conjunta de cada membro do grupo. Para Hall (2003, p. 32), na segunda metade do século XX, um quadro mais perturbado e perturbador do sujeito e da identidade estava começando a emergir dos movimentos estéticos e intelectuais associado com o surgimento do Modernismo. Daí a complexidade do sujeito pós-moderno que inclui, além do fator de desagregação, o deslocamento do sujeito, que pode ser encontrado nos discursos de várias linhas do pensamento moderno.

Para esboçar essa terceira concepção de identidade que levou à fragmentação do sujeito, Hall seleciona cinco teorias das ciências sociais e humanas que tiveram, a seu ver, maior impacto na modernidade tardia e na fragmentação do sujeito: o pensamento marxista ${ }^{141}$, a teoria freudiana do inconsciente, os aportes da lingüística saussuriana, a concepção de "poder disciplinar" foucaultiano e o movimento feminista. Essas teorias influenciaram, cada uma a seu modo, as idéias da modernidade tardia e tiveram efeitos diretos na abordagem e conceituação do sujeito e da identidade: foi a

\footnotetext{
140 HALL, 2003, idem, p. 30.

${ }^{141} \mathrm{O}$ pensamento marxista tendo sido elaborado no século XIX, é considerado pelo autor como um dos avanços importantes das ciências sociais em sua versão reatualizada dos anos 60 .
} 
passagem do indivíduo soberano ao sujeito fragmentado. A principal contribuição do marxismo neste sentido foi o deslocamento do homem do centro para a periferia de seu sistema teórico, priorizando as relações sociais e atuação do grupo. A segunda teoria que contribuiu para deslocar a noção de sujeito, inclusive por seus desdobramentos posteriores, foi a teoria freudiana, que, ao identificar os processos inconscientes como núcleo de articulação motora e volitiva do indivíduo, destruiu a concepção do sujeito cognoscente e racional cartesiano. A leitura que Jacques Lacan faria da teoria freudiana também desempenharia um papel fundamental da apreensão pós-moderna do sujeito. A relação especular que a criança realiza com o Outro inicia sua relação com sistemas simbólicos externos a sua psique que causam sentimentos contraditórios e deixam o sujeito dividido. Psicanaliticamente, nós continuamos buscando a "identidade" e construindo biografias que tecem as diferentes partes de nossos eus divididos numa unidade porque procuramos recapturar esse prazer fantasiado da plenitude. ${ }^{142}$

O terceiro teórico selecionado por Hall, Ferdinand de Saussure fundamenta sua teoria baseando-se no fato de que a língua é um fato social e não individual e que a rede de significados só pode ser estabelecida a partir de uma relação de comparação, similaridade e exclusão. Em processo análogo, a identidade se estabeleceria então a partir da relação com o Outro na qual o sujeito, ao buscar um significado fixo para seu "estar no mundo", depara-se com a diferença que subverte sua tentativa e Ihe dá a medida do caráter inconcluso de sua identidade:

O que modernos filósofos da linguagem - como Jacques Derrida, influenciados por Saussure e pela "virada lingüística" - argumentam é que, apesar de seus melhores esforços, o/a falante individual, não pode , nunca, fixar o significado de uma forma final, incluindo o significado de sua identidade. ${ }^{143}$

142 HALL, 2003, idem, p. 39.

143 HALL, 2003, idem, p. 41. 
Dentro desse quadro de pulverização da concepção de identidade como centro estável e duradouro do indivíduo, Michel Foucault viria acrescentar a medida disciplinar de vigilância do sujeito. O objetivo principal do "vigiar e punir" de Foucault é manter o indivíduo sob estrita vigilância e controle. Ao selecionar esta teoria como uma das principais articulações da modernidade tardia que tiveram influencia direta na nova concepção de identidade, Hall, não deixa de salientar que:

... embora o poder disciplinar de Foucault seja o produto das novas instituições coletivas e de grande escala da modernidade tardia, suas técnicas envolvem uma aplicação do poder e do saber que "individualiza" ainda mais o sujeito [...] quanto mais coletiva e organizada a natureza das instituições da modernidade tardia, maior o isolamento, a vigilância e a individualização do sujeito individual. ${ }^{144}$

Como última categoria de decentramento, o feminismo surge como um dos vários movimentos sociais dos anos sessenta que apelavam para a identidade social de seus membros. Emergindo tanto como movimento quanto como crítica social, o feminismo organiza o movimento reivindicativo de classes e inaugura a "política de identidade". Sua principal relação com o deslocamento do sujeito cartesiano se estabelece a partir da base do movimento, ou seja, o debate sobre a condição e o espaço ocupado pela mulher na sociedade contemporânea, que trouxe a baila o questionamento das relações entre público e privado e a generificação política e social do sujeito.

A segunda metade do século $X X$ trouxe portanto elementos sociais e teóricos que mudariam profunda e definitivamente as concepções de sujeito como ser portador de uma essência, como senhor absoluto de suas ações e, sobretudo, como ser indivisível e coerente. Assim, como há em nós identidades contraditórias, nossas identificações estão sendo continuamente deslocadas, em função de elementos nacionais, culturais, de gênero, de classe social, de

144 HALL, 2003, idem, p. 42-43. 
posição política e religiosa, enfim, das varias identificações que formam o sujeito mosaico de nossa era. ${ }^{145}$

\subsection{Identidade nacional e identidade cultural}

Acabamos de ver como as correntes do pensamento da modernidade tardia marcaram as concepções de sujeito e de identidade. O indivíduo que outrora podia "identificar-se", de modo satisfatório e inquestionável, como membro de uma família, de uma religião, tribo, ou micro-organização social e política, foi 'capturado' pela constituição das grandes nações, deparando-se, posteriormente, com o abalo das verdades e crenças sobre si mesmo e o surgimento das identidades plurais e provisórias das sociedades multiculturais. Dentre as muitas "identidades" do sujeito moderno, a identidade nacional continua sendo um dos centros do debate a respeito da formação das culturas híbridas.

Segundo Hobsbawm, o conceito "liberal" de nação, formulado pelo economista alemão Friedrich List ${ }^{146}$, foi baseado nas idéias do grande federalista americano Alexander Hamilton, "que vinculava a nação, o Estado e a economia, usando este vínculo para justificar contra políticos menos centralizadores sua opção por governos nacionais fortes". Para List, a nação teria que ser grande o suficiente para justificar seu desenvolvimento. Segundo ele,

... um território extenso e uma grande população, dotados de múltiplos recursos nacionais, são exigências essenciais da nacionalidade normal... Uma nação restrita em população ou território, especialmente se possuir uma língua distinta, pode apenas possuir uma literatura estropiada, e

\footnotetext{
${ }^{145}$ FIGUEIREDO, 2005, op. cit., p. 191.

${ }^{146}$ Este conceito foi desenvolvido a partir de idéias desenvolvidas durante sua estada nos Estados Unidos na década de 1820. Este fato torna-se relevante para nós na medida em que a conformidade entre nação, extensão territorial e desenvolvimento econômico, estabelecida por List, formava importante escopo para a demanda expansionista e a empresa colonial.
} 
instituições estropiadas para promover sua arte e ciência. Um estado pequeno não pode, em seu território, promover à perfeição os vários ramos de produção. ${ }^{147}$

Como decorrência desse postulado, Hobsbawm identifica duas conseqüências: a primeira vincula o princípio da nacionalidade somente a nações cujas extensões e população eram grandes o suficiente para produzir benefícios econômicos em larga escala, como era o caso da Grã-Bretanha e da França. O princípio do nacionalismo liberal fundamentava-se portanto no processo de viabilidade de expansão e progresso, o que, na prática, significa proceder segundo a ordem de inclusão e exclusão, pois as "demandas das nacionalidades menores [...] ou das nacionalidades potenciais - sicilianos, bretões, galeses - podiam ser levadas menos a sério ainda. De fato, a palavra Kleinstaaterei (o sistema de mini-Estados) era deliberadamente depreciativa". (HOBSBAWN, 2004, p. 43). A segunda conseqüência foi a inclusão do processo de expansão e unificação como um dos pilares da construção das nações, de modo a fundir as nacionalidades menores, "inferiores e atrasadas", a grandes nações:

Ninguém pode supor que não seja mais benéfico para um bretão, ou para um basco ou Navarro francês ser... um membro da nacionalidade francesa, admitido em termos iguais aos privilégios da cidadania francesa... do que azedar, em suas rochas, o arcaísmo semi-selvagem dos tempos passados remoendo-o em sua pequena órbita mental, sem participação ou interesse no movimento geral do mundo. A mesma observação se aplica aos galeses e escoceses das terras altas, como membros da nação britânica. ${ }^{148}$

Uma outra conseqüência estimada da fusão das nacionalidades menores é o desaparecimento de suas línguas e dialetos. Certamente pensava-se na supremacia das línguas que representavam as leis e a marcha do progresso,

\footnotetext{
${ }^{147}$ LIST, Friedrich apud HOBSBAWN, Eric J. Nações e Nacionalismo desde 1780: Programa, mito e realidade. Tradução: Maria Célia Paoli; Anna Maria Quirino. 4. ed. Rio de Janeiro: Paz e Terra, 2004, p. 42.

148 MILL apud HOBSBAWN, 2004, op. cit., p. 46.
} 
mas não se cogitava a transformação e a interpenetração de diferentes idiomas, ou ainda a existência inócua do pluriligüismo. Mas Hobsbawm levanta ainda estes problemas como questões das nacionalidades menores e aponta três critérios que, na prática, permitiam que uma nação fosse classificada como tal. O primeiro critério era sua associação histórica com um Estado existente ou com um Estado de passado recente e razoavelmente durável; o segundo, era dado pela existência de uma elite cultural longamente estabelecida, que possuísse um vernáculo administrativo e literário escrito; e o terceiro, que infelizmente precisa ser dito, era dado por uma provada capacidade para a conquista (HOBSBAWN, 2004, p. 49).

Como aponta Stuart Hall (2003, p. 59), a lealdade e a identificação simbólica nunca foram suficientes para compor uma cultura nacional. A conquista de novos territórios, a imposição de uma língua que adquire o status vernacular e a supressão da identificação ou sentimento de pertencimento com relação às sociedades tradicionais formam a equação da formação das identidades nacionais, mas não são suficientes para reunir o sujeito pósmoderno em um único sentimento de pertencimento. Além disso, o fenômeno do decentramento do sujeito abriu a possibilidade para o indivíduo de pertencer, simultaneamente, a vários núcleos de identificação, constituindo assim a natureza híbrida da identidade. O elo que serviu como elemento aglutinador na era moderna não consegue produzir o mesmo efeito em comunidades que não têm o Estado-nação como única referência de pertencimento, o que, por conseguinte, vincula seus membros à necessidade de "reconhecimento":

... a exigência de reconhecimento torna-se urgente devido aos supostos elos existentes entre o reconhecimento e a identidade, nos quais este último termo designa algo equivalente à interpretação que uma pessoa faz de si mesma e das características fundamentais que a definem como ser humano. A tese é que nossa identidade é moldada, em parte, pelo reconhecimento ou pela ausência deste; ou ainda, pelo falso reconhecimento dos demais; assim, um indivíduo ou um grupo de pessoas pode sofrer um verdadeiro dano, uma autêntica deformação, se 
as pessoas ou a sociedade que o rodeiam Ihe apontam, como reflexo, um quadro limitativo, degradante ou depreciativo de si mesmo. ${ }^{149}$

O falso reconhecimento, ou a ausência deste, pode afetar diretamente a auto-imagem e aprisionar o indivíduo em uma concepção depreciativa de si e de seu estar no mundo. Assim, os movimentos sociais de reivindicação do reconhecimento encontraram seu apoio na supressão a auto-depreciação induzida pelos mecanismos de controle e opressão, como ocorreu com os negros, os índios e todos os povos subjugados pela colonização.

Sentimento de pertença e necessidade de reconhecimento formam, portanto, dois importantes articuladores para a formação da noção de identidade cultural. Segundo a argumentação de Anna Kindler, ao se considerar a identidade cultural do ponto de vista da pertinência,

... é essencial reconhecer que este senso de pertinência se estabelece não como processo histórico, mas vivencial. Embora o reconhecimento das raízes étnicas e culturais certamente seja parte dessa equação, o contexto da experiência quotidiana provê importante indicativo sobre a identidade cultural de um indivíduo. [...] se cultura for definida em termos mais amplos, e a identidade cultural como senso de pertinência que é moldado pela interseção de múltiplas influências, a possibilidade de celebrar transformações culturais se abre a nós. ${ }^{150}$

O que Kindler classifica como processo vivencial pode ser apreendido como o momento de atuação efetiva no qual o indivíduo, consciente ou

149 ... la exigencia de reconocimiento se vuelve apremiante debido a los supuestos nexos entre el reconocimiento y la identidad, donde este último término designa algo equivalente a la interpretación que hace uma persona de quién es y de sus características definitorias fundamentales como ser humano. La tesis es que nuestra identidad se moldea em parte por el reconocimiento o por la falta de este; a menudo, también, por el falso reconocimiento de otros, y así, un individuo o un grupo de personas puede sufrir un verdadero daño, uma auténtica deformación si la gente o la sociedad que lo rodean le muestran, como reflejo, un cuadro limitativo, o degradante $o$ depreciable de si mismo. (TAYLOR, Charles. El multiculturalismo y "la política del reconocimiento". Comentarios de Amy Gutmann, Steven C. Rockefeller, Michael Walzer y Susan Wolf. México: Fondo de Cultura Económica, 2001. p. 43-44).

150 KINDLER, Anna M. Multiculturalismo e formação da identidade cultural. In: FIGUEIREDO, Eurídice; PRATI DOS SANTOS, Eloína. (Org.). Recortes transculturais. Niterói: EDUFF: ABECAN, 1997. p. 18-22. 
inconscientemente, reconhece, nas interseções das múltiplas influências que caracterizam sua natureza híbrida, a necessidade da negociação.

Homi K. Bhabha enfatiza a necessidade de focalizar os momentos ou processos que se evidenciam na articulação das diferenças culturais:

Esses "entre-lugares" fornecem o terreno para a elaboração de estratégias de subjetivação - singular ou coletiva - que dão início a novos signos de identidade e postos inovadores de colaboração e contestação, no ato de definir a própria idéia de sociedade. É na emergência dos interstícios - a sobreposição e o deslocamento de domínios da diferença - que as experiências intersubjetivas e coletivas de nação [nationness], o interesse comunitário ou o valor cultural são negociados. ${ }^{151}$

No romance que constitui o objeto deste trabalho, o personagem principal se abstém dessa negociação. Apesar de sua recusa em aceitar ser identificado por meio de uma carteira de identidade, ele é presa fácil da institucionalização da afiliação. O termo negociação seria absolutamente inadequado ao perfil de Fama, uma vez que negociação implica em acordo entre as partes, o que também subentende a necessidade de um mínimo de concessão. Fama não se mostra afeito a esse gênero de transigência porque recusa o pertencimento múltiplo. Mas o enfoque da ruptura entre tradição e modernidade como eixo estruturante da narrativa não invalida a existência desses entre-lugares aos quais Homi Bhabha faz referência. Entendemos que, nesses termos, seja possível averiguar a predisposição dos personagens a uma negociação dos termos que definem a identidade de cada um em meio à pluralidade. Guardadas as devidas proporções, o processo de formação das nações africanas assemelha-se ao processo de expansão e unificação das grandes nações do Ocidente pela depreciação das nacionalidades menores, consideradas inferiores e atrasadas e presas a um arcaísmo semi-selvagem dos tempos passados. ${ }^{152}$

151 BHABHA, Homi K. O local da cultura. Tradução: Myriam Ávila et al. Belo Horizonte: Editora UFMG, 2003. p. 20.

152 MILL apud HOBSBAWN, op. cit., 2004, p. 4. 
Se é possível observar essa semelhança entre esses dois momentos histórica e circunstancialmente tão distantes um do outro, é necessário também retomar o que dissemos anteriormente a respeito da incidência da desagregação e do decentramento do sujeito pós-moderno na constituição identitária do homem africano. O longo processo que separa o indivíduo soberano do Iluminismo do sujeito pós-moderno foi suprimido pela colonização que, de certo modo, colocou em contato direto o homem recém-saído do universo de pertencimento único da tradição com uma concepção de sujeito cujas determinações são marcadas pela constante alteração de padrões de comportamento e de interação social. A seleção, consciente ou inconsciente, frente às muitas possibilidades que se oferecem, além de responder à necessidade de reconhecimento, preserva o indivíduo contra o risco de se perder na indeterminação ou de prostrar-se diante de aspirações impossíveis, como no caso de Fama, cujo desejo mais profundo é a restituição da cheferia, de seus bens e de seu poder.

Se o autor reforça as oposições dicotômicas entre tradição e modernidade, elimina, de certo modo, o processo dialético do encontro de culturas distintas. Compreende-se a necessidade de reforçar as oposições pelas circunstâncias históricas em que se deu tal encontro: o caráter abjeto e a violência da colonização justificam amplamente o enfoque da obra. No entanto, a declarada intenção política, aliada ao caráter realista dos romances africanos no período que sucedeu as independências, levaram naturalmente o autor a extrair os principais elementos de sua ficção da realidade imediata, o que nos leva a supor que a articulação entre tradição e modernidade, os dados que extrapolavam tal dicotomia já se inscrevem no romance. De fato, a perspectiva do narrador, em muitos aspectos coincidentes com a do autor, privilegia uma visão dicotômica consoante a seu julgamento de valor a respeito do momento histórico real em detrimento dos processos, já em andamento, de desmantelamento da concepção de identidade como centro estável e duradouro do indivíduo. Se Kourouma parte de uma crise de identidade de seu personagem principal para expor a situação espúria da política das 
independências africanas, seu objetivo visa tão somente a denúncia da morte da tradição e da corrupção dos governos que sucederam o colonizador. Mas, como assinala Michel Butor, cabe ao crítico esclarecer as relações que cada romance estabelece com a realidade em que vivemos e descobrir, no fragmento ilusório descrito no romance, o modo como os personagens imaginários preenchem os vazios da realidade e nos instruem a seu respeito dela. ${ }^{153}$

Percorrendo a fortuna crítica de Les soleils des Indépendances, observamos que grande parte dos estudos voltava-se para o aspecto da inovação lingüística, ou seja, a transposição inusitada da linguagem malinké para a língua francesa, uma língua estrangeira há séculos polida pelo uso da escritura. ${ }^{154}$ Ao lado de uma perspectiva que via na contaminação e na hibridização lingüística a "violação" da norma culta da língua francesa, surgiram ainda conclusões partilhadas por bom número da crítica dentre as quais destacamos, em primeiro lugar, a ênfase no romance como modelo da ruptura entre tradição e modernidade que denuncia a calamidade da empresa colonizadora; e, em segundo, a apreensão do tema da esterilidade e da morte como símbolos da destruição efetiva da tradição. A "morte da tradição", no entanto, às vezes carece de precisão. Nem sempre a crítica deixa claro se está se referindo à decrepitude do poder tradicional (BORGOMANO, 2000, p. 137) ou ao desaparecimento da cultura tradicional. Decerto, pode-se objetar a este comentário o fato de que existe uma interdependência entre ambos, mas não se pode negar que evolução ou involução política e cultural não obedecem ao mesmo ritmo e que o desaparecimento de um não implica em anulação imediata do outro. Portanto, ao confiscar o poder político de reis e chefes tradicionais, a colonização não aniquilou os aspectos culturais da vida quotidiana ou das artes africanas. Considerando esses dois aspectos, Amadou Koné conclui que:

${ }^{153}$ [Les] personnages imaginaires comblent des vides de la réalité et nous éclairent sur celle-ci. (BUTOR, 2003, op. cit., p. 11).

154 ... une langue étrangère polie par l'usage de l'écriture depuis des siècles. (GASSAMA, Makhily, op. cit., 1995, p. 43). 
Visto por este ângulo, este romance é uma crítica aos regimes políticos africanos que, com tendência capitalista ou socialista, fomentam os golpes de estado mais ou menos inventados, a arbitrariedade, o nepotismo e consumam o desmantelamento do grupo sem nada propor para substituí-lo. Les soleils des Indépendances pode ser visto como a denúncia de uma situação, mas também como a crítica cáustica de personagens como Fama Doumbouya que se identificam com uma África, em nossa opinião, ultrapassada. A esterilidade de Fama e sua morte no fim do livro podem ser interpretadas como a morte irremediável desta África ${ }^{155}$ [tradicional].

Com relação à primeira conclusão, acreditamos que se evidencia por ser substrato e superfície do tema tratado. Quanto à segunda, pensar nos funerais da tradição incomoda sobremaneira, pois tal visão invoca o princípio da aculturação, uma visão parcial da aquisição de uma outra cultura suplantada, desde 1940, pela noção de transculturação ${ }^{156}$, cunhada por Fernando Ortiz em El contrapunteo del tabaco y del azúcar:

Entendemos que o vocábulo transculturação expressa melhor as diferentes fases do processo de transição de uma cultura para outra, porque este processo não consiste somente em adquirir uma cultura diferente, o que, a rigor, significa o vocábulo anglo-saxão acculturation, porém o processo implica também, necessariamente, na perda, no desenraizamento de uma cultura anterior, o que se poderia chamar de uma desculturação parcial, e, além do mais, significa a criação conseqüente de novos fenômenos culturais, que se poderiam denominar neo-culturação. Enfim, como bem sustenta a escola de Malinowski, em todo enlace de culturas ocorre o mesmo que na cópula genética dos indivíduos: a criança sempre tem algo de seus progenitores, mas sempre algo diferente de cada um dos dois. Na sua totalidade, o processo é uma transculturação, e esse vocábulo compreende todas as fases da sua parábola. ${ }^{157}$

${ }^{155}$ Vu sous cet angle, ce roman est une critique des régimes politiques africains qui, de tendance capitaliste ou socialiste, couvent les coups d'état plus ou mins inventés, l'arbitraire, le népotisme et parachèvent l'éclatement du groupe sans rien proposer pour le remplacer. Les soleils des Indépendances peut apparaître comme la dénonciation d'un état mais aussi comme la critique caustique de personnages tels que Fama Doumbouya qui s'identifient à une Afrique à notre avis dépassée. La stérilité de Fama, sa mort à la fin du livre, peuvent être interpretées comme la mort irrémédiable de cette Afrique-là. (KONÉ, Amadou, 1985, op. cit., p. 128-129).

156 Grifos nossos.

157 ORTIZ, Fernando. Do fenômeno social da "transculturação" e de sua importância em Cuba. Tradução: Lívia Reis. In: Contrapunteo cubano del tabaco y del azúcar.. 
Note-se que Ortiz valida como opção do desenraizamento de uma cultura anterior a combinação desculturação parcial. Isso equivale a dizer que no processo de transição de uma cultura à outra, mesmo que muito se perca, algo sempre permanece. Por isso o incômodo com as afirmações que decretam a morte da tradição, salvo os casos em que se considere essa morte sob a perspectiva da cultura africana, ou seja, sob a perspectiva da transformação e da continuidade. Embora tida como um flagelo tanto para o indivíduo quanto para a comunidade, "para os africanos, os mortos não estão mortos: eles sobrevivem sob forma de energia" (ZADI ZAOUROU, 2006) ${ }^{158}$. Além disso, a concepção de morte definitiva da tradição amputaria um dos termos da equação que resulta na formação das culturas híbridas ou compósitas (GLISSANT, 1997b).

As noções que fundamentam os debates sobre a questão da identidade nos dias atuais são a pluralidade e a impermanência, dois aportes nascidos do deslocamento das concepções do sujeito essencial e cartesiano por meio dos movimentos sociais e das teorias da modernidade tardia, mas que preocupam cada vez menos. Desde o final do século passado, Homi Bhabha (2003, p. 19) abordava as questões do trânsito, do entre-lugar e das vidas na fronteira do presente, para as quais não parece haver nome próprio além do atual e controvertido deslizamento do prefixo "pós": pós-modernismo, póscolonialismo, pós-feminismo... Pluralidade, hibridismo, impermanência, deslocamento, decentramento, negociações feitas nos interstícios: estratégias de subjetivação de um tempo de transformações incessantes e de mutações contínuas processadas no tempo. A sobreposição do tempo na modernidade à espacialidade como âncora das sociedades tradicionais é discutida por Zygmunt Bauman em um conjunto de obras que apontam para o que chamou

La Habana: Editorial de Ciencias Sociales, 1983. Texto em versão digital disponibilizado na página Antologia de Textos Fundadores do Comparatismo Literário Interamericano.

${ }^{158}$ Entrevista concedida a Maria Suzana Moreira do Carmo, em março de 2006, em Abidjan, Costa do Marfim. Inédito em anexo. 
de liquefação da modernidade. No caso preciso do interesse de nossa pesquisa, não fixaremos tanto nossa atenção sobre a "modernidade líquida", fruto do cenário globalizante que vivemos atualmente, mas sobre os aspectos da leitura de Bauman que concernem mais diretamente o desenvolvimento das sociedades sólidas (pré-modernas) às sociedades líquidas (pós-modernas).

\subsection{Novos sólidos e modernidade líquida}

Dentro de uma perspectiva da evolução social e histórica caucionada pela economia e pela interpelação política, Bauman retraça os caminhos que levaram o sujeito a perder os vínculos com as comunidades de vida e de destino e a ligar-se cada vez mais às comunidades "fundidas unicamente por idéias ou por uma variedade de princípios".

Baseando-se em propriedades da física da matéria, Zygmunt Bauman elabora a metáfora do derretimento dos sólidos para ilustrar a passagem das sociedades ditas tradicionais, ou sólidas, à modernidade líquida, enfatizando o saldo deixado pela modernidade na vida humana. Considerando as dimensões espaciais dos sólidos que neutralizam os impactos e diminuem a ação do tempo, resistindo e tornando seu fluxo irrelevante, Bauman compara suas propriedades às comunidades tradicionais, definida nos seguintes termos:

... a "sociedade", entendida como a maior totalidade da coabitação humana (se é que elas pensavam nesses termos), era igual à vizinhança adjacente. [...] No interior dessa rede de familiaridade do berço ao túmulo, o lugar de cada pessoa era evidente demais para ser avaliado, que dirá negociado. ${ }^{159}$

159 BAUMAN, Zygmunt. Identidade: Entrevista a Benedetto Vecchi. Tradução: Carlos Alberto Medeiros. Rio de Janeiro : J. Zahar, 2005. p. 24. 
Em contrapartida, as propriedades do estado líquido oferecem a metáfora mais adequada à descrição do estágio atual "da era moderna"160. Os líquidos em sua fluidez, "não fixam o espaço nem prendem o tempo"; para que um líquido ocupe um espaço e mantenha uma determinada forma, ele necessita algum tipo de resistência que contenha sua tendência ao fluxo contínuo. "Os fluidos não se atêm muito [tempo a uma] ${ }^{161}$ forma e estão constantemente prontos (e propensos) a mudá-la; assim, para eles, o que conta é o tempo, mais do que o espaço que Ihes toca ocupar; espaço, que, afinal, preenchem apenas 'por um momento' (2001, p. 8)". A era da modernidade líquida é, portanto, o momento das relações globalizadas, dos mundos livres de suas cercas e barreiras que propicia a fluidez dos laços sociais e das técnicas de poder.

A passagem da sociedade sólida à modernidade líquida compreende uma fase intermediária: trata-se do advento da era moderna, quando os Estadosnação derrubaram as antigas organizações sociais baseadas nas hierarquias e elegeram a natividade como modo de legitimação e veículo de subordinação de seus indivíduos. Segundo a metáfora baumaniana, esse estágio da história moderna constitui o momento da substituição de um sólido por outro ou, em outras palavras, a sobreposição da natividade aos laços de sangue. De modo similar à análise de Stuart Hall (2003), Bauman reconhece na constituição das grandes nações o momento em que o indivíduo deixa de contar com uma identificação satisfatória e inequívoca e passa a ser reconhecido por sua

160 Optamos por deixar entre aspas a expressão empregada por Bauman a fim de destacar uma certa crise terminológica quanto à definição do atual momento dessa pós-modernidade avançada. Como assinalou Homi Bhabha, não parece haver nome próprio além do atual e controvertido deslizamento do prefixo "pós". (BHABHA, 2003, op. cit., p. 19).

${ }^{161}$ Inserimos a expressão entre colchetes a fim de corrigir uma omissão que constitui um erro de conceituação da física, alterando as propriedades da matéria. Como verificamos que se tratava de um problema de tradução, citamos a seguir o texto original: fluids do not keep to any shape for long and are constantly ready (and prone) to change it; and so for them it is the flow of time that counts, more than the space they happen to occupy.

Disponível na página < http://www.informatik.umu.se/ mwiberg/cmid07 mw.pdf. $>$, acesso: 6/11/07, 00:43. 
resposta à exigência de lealdade e à subordinação exigidas pela Nação à qual se vincula. Bauman caracteriza este processo como a crise do pertencimento estável e o surgimento de uma ficção: a identidade nacional que, posteriormente, levaria o indivíduo a cogitar outros tipos de pertencimento. $\mathrm{Na}$ verdade,

perguntar "quem você é" só faz sentido se você acredita que possa ser outra coisa além de você mesmo; só se você tem uma escolha, e só se o que você escolhe depende de você; ou seja, só se você tem de fazer alguma coisa para que a escolha seja "real" e se sustente. Mas foi justamente isso que não ocorreu aos moradores das aldeias atrasadas e dos povoados da floresta - que nunca tiveram a oportunidade de mudar de lugar, muito menos procurar, descobrir ou inventar algo tão nebuloso (na verdade tão impensável) como uma "outra identidade". Sua forma de estar no mundo eliminava da questão da "identidade" o significado tornado óbvio por outros modos de vida - modos que nossos usos lingüísticos nos estimulam a chamar de "modernos". ${ }^{162}$

Comparando os modelos estabelecidos por Hall (2003) e Bauman (2001), percebemos que, por trás da terminologia distinta, é possível detectar pontos de vista semelhantes. Tanto Hall quanto Bauman analisam as mudanças operadas nas concepções de agrupamentos sociais e de sujeito a partir do marco da era moderna, ou seja, a queda das hierarquias do Antigo Regime e a constituição do Estado-nação. Examinando o saldo que a modernidade deixou sobre a vida humana, Bauman reconhece os mesmos movimentos citados por Hall, mas sua perspectiva concentra-se no que denominou como estruturas sólidas e líquidas, enfatizando o deslocamento do pertencimento a estruturas tradicionais para a "redistribuição e realocação dos "poderes de derretimento" da modernidade. Aproximando suas interpretações da passagem da era pré-moderna à modernidade tardia e ao advento da globalização atual, constatamos a convergência de seus pontos de vista. No entanto, à instabilidade, à variabilidade e à mutação das identidades, Bauman acrescenta o aspecto cambiante da relação espaço-tempo que consideramos mais adequado à interpretação do processo de mutação revelado pela relação

162 BAUMAN, 2005, idem, p. 25-26. 
espaço-temporal da ficção, que, a nosso ver, apontam para a formação dos "laços efêmeros".

O "derretimento dos sólidos" é parte da metáfora ideal encontrada por Zygmunt Bauman para referir-se ao início do processo de mutação decorrente do contato entre diferentes culturas. Seu enfoque, como os autores acima citados, é também o dos processos ocorridos no ocidente que viriam alterar, de forma radical, as relações do homem com o meio social e as concepções de sujeito e identidade. Para Bauman a identidade "só nos é revelada como algo a ser inventado e não descoberto."

Um dos traços do estágio sólido da era moderna era que a cidadania se relacionava diretamente ao assentamento. A modernidade viria então desfazer essa concepção do elo seguro e estável dos estamentos hereditários para propor, em seguida, um novo tipo de dependência ou de "pertencimento":

Na verdade, nenhum molde foi quebrado sem que fosse substituído por outro; as pessoas foram libertadas de suas velhas gaiolas apenas para ser admoestadas e censuradas caso não conseguissem se realocar, através de seus próprios esforços dedicados, contínuos e verdadeiramente infindáveis, nos nichos pré-fabricados da nova ordem: nas classes, as molduras que (tão intransigentemente quanto os estamentos já dissolvidos) encapsulavam a totalidade das condições e perspectivas de vida e determinavam o âmbito dos projetos e estratégias realistas de vida. A tarefa dos indivíduos livres era usar sua nova liberdade para encontrar o nicho apropriado e ali se acomodar e adaptar: seguindo fielmente as regras e modos de conduta identificados como corretos e apropriados para aquele lugar. ${ }^{163}$

Um dos marcadores utilizados por Bauman para definir a modernidade, além do já mencionado dado histórico dos efeitos da queda das hierarquias do Antigo Regime, é a separação das categorias de espaço e tempo. Tais categorias passaram da aparente invulnerabilidade da correspondência biunívoca vivida pelo homem à categorias distintas entre si: a "flexibilidade e expansividade" do tempo permitiu que ele se tornasse "a arma na conquista do espaço":

163 BAUMAN, Zygmunt. Modernidade líquida. Tradução: Plínio Dentzien. Rio de Janeiro : J. Zahar, 2001. p. 13. 
Na luta moderna entre tempo e espaço, o espaço era o lado sólido e impassível, pesado e inerte, capaz apenas de uma guerra defensiva, de trincheiras - um obstáculo aos avanços do tempo. O tempo era lado dinâmico e ativo na batalha, o lado sempre na ofensiva: a força invasora, conquistadora e colonizadora. A velocidade do movimento e o acesso a meios mais rápidos de mobilidade chegaram nos tempos modernos à posição de principal ferramenta do poder e da dominação. ${ }^{164}$

Para Bauman, a velocidade do tempo e seu uso como arma de conquista revertem as estruturas de comando, na modernidade tardia, permitindo que o poder se torne verdadeiramente 'extraterritorial', não mais limitado, nem mesmo desacelerado, pela resistência do espaço. Este é o fim do Panóptico foucaultiano que exigia a presença dos controladores, o momento em que o exercício de controle do "vigiar e punir" deixa de depender de uma conjuntura espacial e rejeita todo e qualquer confinamento territorial:

O que importa, nas relações de poder pós-panópticas é que as pessoas que operam as alavancas do poder de que depende o destino dos parceiros menos voláteis na relação podem fugir do alcance a qualquer momento - para a pura inacessibilidade. ${ }^{165}$

A medida disciplinar descrita por Michel Foucault constituiu, como apontou Stuart Hall, uma das importantes teorizações da modernidade tardia que influenciaram as concepções de identidade. Vimos que, embora o poder disciplinar seja o produto de instituições coletivas, a vigilância e o isolamento contribuíram para a individualização do sujeito. Naturalmente, a análise de Bauman se refere ao período posterior ao momento enfocado por Hall, mas tal abordagem não deixa de ter interesse para nós, na medida em que nos permite situar duas concepções de comando dentro da estrutura ficcional que propomos analisar. O referente histórico - e, portanto espaço-temporal - do romance Les soleils des Indépendances é suficientemente delimitado para fins de desenvolvimento da trama e mobilização temática: trata-se do período que sucedeu a independência da Costa do Marfim e, por extensão, dos demais

164 BAUMAN, 2001, idem, p. 15.

165 BAUMAN, 2001, idem, p. 18. 
países do oeste africano, colonizados pelos franceses. No entanto, a extensão temporal da narrativa compreende o período colonial, recuperado pelo exercício da memória, e o presente imediato, onde o tempo do personagem coincide com o tempo do autor. Além da concepção da modernidade como a era do derretimento dos sólidos, a teoria de Bauman compreende também o estudo das estruturas de poder e comando extraterritorial que se estabelece no mundo das articulações globalizadas. Assim, o aspecto mais contemporâneo de sua interpretação nos interessa na medida em supomos poder localizar no romance de Ahmadou Kourouma alguns dados que, pelo influxo dos contatos com o ocidente, apontam para a ação do poder inacessível e para a influência da aceleração do tempo que leva à rapidez nas negociações entre os indivíduos e na fragilidade dos laços afetivos.

O encontro entre tradição e modernidade obrigou o indivíduo a uma reflexão até então dispensável para o seu quadro de vida habitual. No que se refere precisamente aos países colonizados, as ações políticas das colônias se apropriaram, em um primeiro momento, do sistema de organização social tradicional segundo seus interesses ${ }^{166}$, angariando simpatizantes e adeptos à causa européia e eliminando, senão de fato ao menos de direito, os recalcitrantes, os indecisos e os revoltosos. Os primeiros foram absorvidos pelo sistema colonial, quanto aos segundos, engrossaram, em geral, as fileiras dos excluídos ou soçobraram na alienação como manifestação patológica da opressão.

As culturas nacionais são uma forma distintivamente moderna. A lealdade e a identificação que, numa era pré-moderna ou em sociedades mais tradicionais, eram dadas à tribo, ao povo, à religião e à região, foram transferidas, gradualmente, nas sociedades ocidentais, à cultura nacional. ${ }^{167}$

\footnotetext{
${ }^{166}$ Ver os capítulos "Povo e cultura malinké" e "Da cheferia tradicional à administração colonial", na primeira parte deste trabalho.

167 HALL, 2003, op. cit., p. 49.
} 
Um processo similar de transferência de lealdade e identificação das sociedades tradicionais às culturas nacionais, ou, mais especificamente, à demanda institucional de modelo ocidental, pode ser encontrado na colonização. No entanto, ao modo gradual há que se substituir o abrupto, o invasivo e o violento. Vale lembrar ainda que o europeu que comandava in loco as colônias, além de sua conformação sócio-cultural e política ocidental, sempre esteve em contato com a Europa. Assim, as transformações que lá ocorreram incidiram, por refração, em seu modo de vida e em suas concepções de organização social e política das colônias. Hall enfatiza ainda a característica violenta da formação das nações ocidentais que se repetem nas expansões territoriais no ocidente:

A maioria das nações consiste de culturas separadas que só foram unificadas por um longo processo de cultura violenta - isto é, pela supressão forçada de diferença cultural. [...] Ao longo de toda a Europa, essa história se repete ad nauseam. Cada conquista subjugou povos conquistados e suas culturas, costumes, línguas e tradições, e tentou impor uma hegemonia cultural mais unificada. ${ }^{168}$

De certo modo, podemos dizer que o modus operandi nas expansões e explorações coloniais refletiu a transposição de uma tática que já havia provado sua eficiência em solo europeu pela coerção às nacionalidades "menores, inferiores e atrasadas", obrigadas a fundir-se às grandes nações.

As transformações associadas à era moderna no ocidente desalojaram o indivíduo habituado à estabilidade da ordem secular e proporcionaram o surgimento do indivíduo soberano, definido em termos de sua natividade e protegido por um Estado que não admitia concorrência em termos de identidade. No caso da colonização, com a chegada do europeu, o homem africano, que jamais havia concebido sua existência sob a perspectiva da individuação e exclusão da comunidade, se viu igualmente subtraído da segurança garantida pela sociedade tradicional e passou a ser definido em termos de sua natividade, sendo então protegido por um Estado, a seu ver,

168 HALL, 2003, op. cit., p. 59-60. 
ilegítimo. Vale lembrar que, na África, a concepção de nação - que constitui uma afiliação de peso para as concepções de identidade da era moderna - é uma herança bastante recente da colonização, e ainda, que o efeito da ruptura promovida pela chegada do homem branco torna-se mais extremo se considerarmos, não a semelhança, mas o ponto de divergência com o processo de formação das nações na era moderna ocidental.

Os tempos modernos encontraram os sólidos pré-modernos em estágio avançado de desintegração e um dos motivos mais fortes por trás da urgência em derretê-los era o desejo de, por uma vez descobrir ou inventar sólidos de solidez duradoura, solidez em que se pudesse confiar e que tornaria o mundo previsível e, portanto, administrável. ${ }^{169}$

Este não foi o caso dos sólidos africanos, que sequer questionavam a solidez de suas organizações sociais, de suas crenças, de seus mitos ou afiliações. Afinal, como nos mostrou Bauman, a solidez dos pertencimentos e a identidade individual só podem ser questionados a partir do momento em que há alternativa para aquilo que se é, ou se acredita ser. Enquanto o indivíduo estiver tramitando confortável e seguramente em meio aos elementos que constituem seu sentimento de pertença única, não há subsídios para que levante suspeitas sobre seus vínculos.

Assim, partindo da metáfora baumaniana de modernidade sólida e modernidade líquida, propomos analisar o romance Les soleils des Indépendances sob a perspectiva da substituição de um sólido por outro, ou seja, como a mudança operada na passagem da tradição à modernidade, da qual se deduzem dois corolários: o primeiro, imediato, produz uma aceleração nas respostas aos estímulos e criam um conflito que leva o indivíduo a uma reorganização das pertenças que compõem sua identidade e compreende processos de seleção, assimilação ou rejeição; o segundo, diferido, anuncia de maneira subliminar um traço atribuído à modernidade líquida, na qual a noção de tempo se sobrepõe à de espaço.

169 BAUMAN, 2001, op. cit., p. 10. 
Para fins de elucidação metodológica, esclarecemos a seguir o percurso da análise dividindo-a em dois eixos de demonstração. Em primeiro lugar, mostraremos os processos de ruptura que estruturam o romance e o modo como eles refletem, no plano de uma dinâmica identitária, as transformações e reacomodações dos indivíduos aos novos nichos impingidos pela nova ordem: as 'classes', as molduras que (tão intransigentemente quanto os 'estamentos' já dissolvidos) encapsulavam a totalidade das condições e perspectivas de vida e determinavam o âmbito dos projetos e estratégias realistas de vida (Bauman, 2001, p. 13). Em segundo, passaremos à analise dos níveis de absorção e reação à incidência da modernidade a fim de determinar o grau de adequação dos principais personagens à demanda da nova ordem de mestiçagem cultural. Esta etapa visa ainda determinar de que modo é possível identificar, no romance, a aceleração do tempo da pós-modernidade como um influxo de processos externos à realidade africana, mas que se insinua pela ponte estabelecida com o velho continente e apontam, de modo subliminar, para a prefiguração laços frágeis e efêmeros da modernidade líquida.

\section{Estética da oralidade e ascendência ocidental}

Na segunda parte deste estudo, vimos como o romance africano, a despeito de sua orientação temática ou ideológica, reflete a transculturação resultante do encontro da cultura ocidental com a tradição africana. Mesmo adquirindo autonomia na expressão de sua individualidade, os escritores mantiveram um vínculo com o passado pré-colonial, evocando a tradição por meio da temática, do estilo ou da estrutura formal da obra.

Ao abordar as transformações do romance africano, Makhily Gassama afirma a importância de Les soleils des Indépendances como um marco na busca da singularidade das literaturas africanas: 
O romancista negro africano está em busca - sobretudo depois dos "soleils des Indépendances" - dos modos de expressão que lhe permitam distinguir-se do romancista ocidental e dos meios de comunicação suscetíveis de imprimir em sua obra uma marca autenticamente negro-africana. Aliás, é preciso reconhecer que não é pela escolha dos temas que um romancista negro consegue distinguir-se de seu homólogo ocidental, sobretudo do romancista colonial; em nossa opinião, sua originalidade só pode residir na maneira de apreender os temas relativos à civilização negro-africana e na escolha dos modos de expressão que não se separam dos valores dos meios [sociais] que descreve. ${ }^{170}$

Gassama não ignora que o romance é um gênero ocidental por excelência e que, como tal, faz parte da herança que a África recebeu da "civilização da escritura", mas também não deixa de acentuar o modo original dos escritores africanos de abordar os temas, reconhecendo a parte da ascendência tradicional que forja grande parte dos modos de expressão do romance africano. Ainda assim, ao comparar o romance à poesia e ao conto, surge como representação do romancista africano a imagem de "órfão desamparado". A imagem de desamparo do escritor que se debruça sobre este gênero ignorado pela cultura tradicional, se baseia, sobretudo, no que o autor considera a grande solidão do romancista que, amputado de uma filiação artística tradicional, não goza dos mesmos privilégios do poeta e do contista negros, ambos beneficiários da rica tradição literária negro-africana.

Como dissemos anteriormente ${ }^{171}$, Kourouma creditou sua incursão pela literatura a duas razões fundamentais: a decepção com os documentos sociológicos e etnológicos referentes ao continente africano e seu desejo

170 Le romancier négro-africain est à la recherche - surtout depuis les «soleils des Indépendances »- des modes d'expression pouvant lui permettre de se distinguer du romancier occidental, des moyens de communication susceptibles d'imprimer à son oeuvre un cachet authentiquement négro-africain. Du reste il est à reconnaître que ce n'est pas par le choix des thèmes qu'un romancier nègre pavient à se distinguer de son homologue occidental, surtout du romancier colonial ; son originalité, à notre avis, ne peut résider que dans la manière d'appréhender les thèmes relatifs à la civilisation négro-africaine et dans le choix des modes d'expression qui ne divorcent pas d'avec les valeurs des milieux qu'il dépeint. (GASSAMA, Makhily. Kuma: interrogation sur la littérature nègre de langue française (poésie-roman). Dakar-Abidjan: NEA, 1978. p. 236-237).

${ }^{171}$ Cf. Parte I, capítulo 1 deste trabalho. 
profundo de denunciar as mazelas da era das independências. Essa preocupação em transmitir a realidade africana levou-o a compor seu primeiro romance de modo a traduzir uma determinada realidade que tramitava entre dois códigos culturais distintos. Como decorrência natural do encontro de culturas, o continente africano que Ahmadou Kourouma pretendia descrever havia passado pelo processo de "desculturação parcial" e pela criação de novos fenômenos culturais. Portanto, com sua profunda consciência dessa mestiçagem cultural, Kourouma tinha diante de si a difícil tarefa de harmonizar a transmissão de uma realidade miscigenada com uma recepção presumida de leitores que, em sua maioria, não dispunham do conhecimento de um dos códigos culturais que compunham essa realidade. Afinal, se 0 autor considerava que as informações científicas a respeito do homem e da sociedade africana não correspondiam de fato à realidade, a idealização do negro e da tradição africana veiculada pelo movimento da Negritude também não favorecia a imagem da África projetada no Ocidente. Uma imagem distorcida, fundada por estereótipos. A solução encontrada para aproximar o leitor não africano desse código ao qual não tinha acesso foi a sobreposição do pensamento malinké à língua francesa ou, em outros termos, a priorização do kumaña 172 em detrimento da concepção ocidental de linguagem, materializando "a adequação da expressão ao pensamento" defendida por Gassama:

[...] é evidente que o que nos interessa não é tanto a natureza e as virtudes da língua na qual o escritor se exprime, mas o valor real de

172 Segundo a definição de Makhily Gassama, o termo kuma significa "discurso" em bambara; kuma, dizem os Bambara, tem uma afinidade com a cauda, ku. Comparável a este órgão - prolongamento do corpo dos animais - a palavra "caminha" na trilha de seu proprietário, é uma "extensão" da pessoa e permite apreendê-la (...) A palavra kuma compreende qualquer enunciação do pensamento pelo discurso, ao mesmo tempo que o conjunto da linguagem e do ensino [kuma, disent les Bambara, est en affinité avec la queue, ku. Comparable à cet organe - prolongement du corps des animaux - la parole «marche » dans le sillage de son propriétaire, «étend» la personne, et donne l'occasion de l'apréhender (...) Le mot kuma concerne toute l'énonciation de la pensée par la parole, en même temps que l'ensemble du langage et de l'enseignement]. (ZAHAN apud GASSAMA, 1978, op. cit., p. 9). 
algumas técnicas de transmissão da mensagem; e no estudo consagrado aos registros de expressão, não é tanto a pureza da língua francesa que nos preocupa, mas a criação de uma certa ilusão sem a qual a mensagem perde toda a sua consistência. ${ }^{173}$

O meio encontrado por Kourouma para não falsear a expressão dos personagens e dos grupos sociais que descreve, não deixou de suscitar as mais diversas reações sobre o que foi apontado como a "violação" da norma culta da língua francesa. O próprio Makhily Gassama, que já havia analisado o primeiro romance de Kourouma em Kuma - Interrogation sur la littérature nègre de langue française, confessaria, anos mais tarde, em um estudo inteiramente dedicado à língua de Les soleils des Indépendances ${ }^{174}$, seu sentimento de desgosto e até mesmo uma certa repulsa que a primeira leitura do romance havia Ihe causado. Mas embora a expressão do pensamento malinké em língua francesa tenha sido reconhecida como o grande mérito de Kourouma, entendemos que, como para os demais aspectos da obra, o mérito do autor também consiste em dar forma a uma tendência que já se esboçava em outros autores. Amadou Koné ressaltou o uso de termos de expressões idiomáticas africanas em Crépuscule des temps anciens ${ }^{175}$, de Nazi Boni, como exemplo do esforço de autores africanos em adaptar o referente ao modo de expressão:

Nazi Boni, até onde sabemos, é o primeiro a fazer esse uso bastante original desses termos que o poderoso fôlego de Ahmadou Kourouma vai popularizar em Les soleils des Indépendances. Ele introduz várias palavras de seu dialeto. Além disso, emprega termos franceses com um sentido africano. Por exemplo, escreve: "Des générations étaient nées, avaient fait leur soleil et disparu". Nessa frase, a palavra "sol" não tem evidentemente seu sentido de astro. Ela significa "o tempo", "a era". E a

${ }^{173}$ [...] il est évident que ce qui nous intéresse, c'est moins la nature et les vertus de la langue dans laquelle l'écrivain s'exprime, que la valeur réelle de certaines techniques de transmission du message; et dans l'étude consacrée aux registres d'expression, c'est moins la pureté de la langue française qui nous préoccupe, que la création d'une certaine illusion sans laquelle le message perd toute consistance. (GASSAMA, idem, p.8).

${ }^{174}$ La langue d'Ahmadou Kourouma ou le français sous le soleil d'Afrique. Paris : ACCT/ Karthala, 1995.

175 Publicado em 1962, pouco antes do inicio da redação de Les soleils des Indépendances. 
expressão "faire son soleil" é freqüente nas línguas africanas e ela significa "reinar", "conhecer seu tempo de glória"176.

Louis Millogo (2002) aprofundou esta análise de Koné em Nazi Boni premier écrivain du Burkina Faso: La langue bwamu dans Crépuscule des temps anciens, avaliando, entre outros aspectos, a introdução da língua bwamu no enunciado em francês, cujos campos lexicais organizam a estrutura do romance ${ }^{177}$.

Ahmadou Kourouma efetivou, portanto, uma tendência que já se esboçava nas literaturas africanas em geral, como resultado do mal estar provocado pela consciência de que a língua do Outro não bastava para exprimir a complexidade dos grupos sociais e dos indivíduos que se encontram sob os influxos de culturas híbridas. É segundo essa concepção da visão plural que se expressa em Les soleils des Indépendances que faremos a análise dos processos de ruptura que estruturam o romance e refletem as transformações e reacomodações da arte e dos indivíduos aos novos âmbitos culturais.

\subsection{Do griot ao escritor}

No capítulo "Mestres do discurso: do griot ao escritor moderno" fizemos o levantamento dos principais elementos que compõem a narrativa oral, do papel do griot e da passagem da narrativa do griot à narrativa do escritor

\footnotetext{
${ }^{176}$ Nazi Boni, le premier à notre connaissance, fait cette utilisation fort originale de ces termes que le souffle puissant d'Ahmadou Kourouma va populariser dans Les soleils des indépendances. Il introduit de nombreux mots de son dialecte. En plus il emploie des termes français avec un sens africain. Par exemple, il écrit: "Des générations étaient nées, avaient fait leur soleil et disparu". Dans cette phrase, le mot "soleil" n'a évidemment pas son sens d'astre. Il signifie "le temps", "l'ère". Et l'expression "faire son soleil" est courante dans les langues africaines et elle signifie "règner", "connaître son temps de gloire". (KONÉ, A., 1985, op. cit., p. 89).

177 A introdução da língua bwamu no romance de Nazi Boni não tem a mesma amplitude do trabalho de Kourouma em Les soleils des Indépendances. A presença do bwamu limita-se a ao léxico e a sentenças curtas que acrescentam à expressão dos personagens.
} 
moderno, no momento em que a imaginação e a criatividade individual ocupam o lugar da memória. Em sua atividade literária, o griot preservava então o enredo com a precisão dos dados e o rigor na elaboração do discurso. Quanto à evolução de seu status, a análise de Tamsir Niane exige uma certa reflexão que, de certo modo, justifica a longa citação:

Se, hoje, o griot está reduzido a tirar partido de sua arte musical ou mesmo a trabalhar com suas próprias mãos para viver, não foi sempre assim na África antiga. Os griots eram, outrora, Conselheiros dos reis; eles detinham as Constituições dos reinos apenas pelo exercício da memória, cada família nobre tinha seu griot responsável pela conservação da tradição; era entre os griots que os reis escolhiam os preceptores dos jovens príncipes. $\mathrm{Na}$ sociedade africana bem hierarquizada anterior à colonização, onde cada um tinha o seu lugar, o griot surge como um dos membros mais importantes desta sociedade, pois era ele quem, na falta de arquivos, detinha os costumes, as tradições e os princípios de governo dos reis. As reviravoltas sociais devidas à conquista levaram os griots a encontrar, nos dias atuais, um outro meio de sobrevivência: eles tiram partido daquilo que, até então, havia sido seu feudo, ou seja, a arte da palavra e a música. ${ }^{178}$

Niane enaltece os atributos mnemônicos do griot, sua participação na organização social e política da sociedade tradicional, mas lamenta a sobreposição do documento escrito ao talento do griot e, mais ainda, o endosso dessa situação por parte dos intelectuais africanos, que mostram assim o conhecimento de sua terra segundo a visão do homem branco. Embora pertinente, a análise de Niane enfatiza o papel do griot ligado às famílias reais, mas omite a existência dos griots ambulantes, que viajavam

178 Si, aujourd'hui, le griot est réduit à tirer parti de son art musical ou même à travailler de ses mains pour vivre, il n'en a pas toujours été ainsi dans l'Afrique antique. Autrefois les griots étaient les Conseillers des rois, ils détenaient les Constitutions des royaumes par le seul travail de la mémoire; chaque famille princière avit son griot préposé à la conservation de la tradition; c'est parmi les griots que les rois choisissaient les précepteurs des jeunes princes. Dans la société africaine bien hiérarchisée d'avant la colonisation, où chacun trouvait sa place, le griot nous apparaît comme l'un des membres les plus importants de cette société car c'est lui qui, à défaut d'archives, détenait les coutumes, les traditions et les principes de gouvernement des rois. Les bouleversements sociaux dus à la conquête font qu'aujourd'hui les griots doivent vivre autrement : aussi tirent-ils profit de ce qui jusque-là avait été leur fief, l'art de la parole et la musique. (NIANE, Djibril T., 1960, op. cit., p. 5-6). 
pelas cidades e vilarejos e atuavam como contistas, arautos, músicos, aduladores ou difamadores. No entanto, existem alguns traços inerentes a este tipo de griot e ao lugar que ele ocupa na sociedade que são fundamentais para que se possa compreender o perfil dos griots em Les soleils des Indépendances, bem como a função desses personagens na concepção ideológica do autor.

Segundo Camara Sory (1992, p. 63-72), a integração da sociedade malinké é definida de acordo com o posicionamento de três grandes grupos que organizam a disposição hierárquica de seus membros: o grupo dos hóró, que representa o pólo superior do sistema das castas malinké; o grupo dos jô, que se opõe à casta dos hóró e formam o grupo dos cativos; e os ñàmàkálá, que formam o grupo inferior do qual fazem parte os griots. Os ñàmàkálá formam clãs particulares que podem ter acesso a qualquer autoridade política, agrícola ou comercial e obedecem a uma estrita endogamia que os mantém sob rígida estratificação. Assim, os nobres, de acordo com as regras de subordinação hierárquica, obedecem à separação entre as castas e mantém os ñàmàkálá a distância em função do principio de inferioridade atribuído a este grupo. No entanto, mesmo pertencendo a uma casta inferior, os atributos de músico, cantor e mestre do discurso os separam dos demais membros ñàmàkálá e lhes conferem uma certa distinção.

Uma das características da personalidade malinké é a violência, um atributo que pode se traduzir tanto pelas reações físicas, emocionais ou, ainda, pela injúria. A violência explorada nas guerras e batalhas pelos homens de casta superior encontra sua correspondência nos afrontamentos verbais das mulheres e nos discursos injuriosos dos griots. Do mesmo modo que esses "mestres do discurso" podem exaltar as qualidades de heróis, reis e famílias nobres, também são capazes de arruinar ou tiranizar aqueles que se submetem a seu discurso. A agressividade e a chantagem são, portanto, duas características inerentes ao griot malinké; e o meio de aplacar a sua ira é ceder à chantagem e cobri-lo de presentes. 
Como "exemplo épico da agressividade do griot", Camara Sory cita a seguinte lenda:

Querendo provar o poder de sua eloqüência, o ancestral dos griots dirigiu-se à beira do rio para cantar os louvores do Leão da água (o polvo). A este cabia jogar sobre a margem todos os peixes que havia no local. Mas o griot continuou a excitar o animal para exigir ainda mais. $O$ outro dizimou a fauna das águas sem conseguir calar o demônio do discurso ${ }^{179}$. Vendo isso, ele saiu das águas, veio se deitar, de costas, aos pés do homem e morreu. ${ }^{180}$

É interessante observar a denominação dos griots como "demônio do discurso". De fato, em se tratando de uma lenda, a autoria desse episódio nada lisonjeiro para os griots se perde na memória coletiva, mas demonstra dois fatos importantes: o poder coercitivo de seu discurso e a impossibilidade para o alvo de suas maldades de escapar ao constrangimento. Considerando esses aspectos, é possível suspeitar que a ira de Fama contra o griot dos funerais de Koné Ibrahima ultrapassa a revolta contra o fils d'âne de griot (KOUROUMA, LsdI, p. 17) que conduzia a cerimônia, pois sua pobreza material o coloca em uma situação na qual não possui nenhum meio de angariar a simpatia do discurso do griot, revertendo-a do insulto à adulação.

A começar pelo aspecto físico, esse primeiro griot trazido à cena no romance é indicial da concepção de penúria e ultraje da casta: um velho, de aspecto doentio (KOUROUMA, LsdI, p. 13). No entanto, a despeito da situação de miséria aparente, a eloqüência a serviço da ironia e da injúria permanece inabalável:

\footnotetext{
179 Grifos nossos.

180 Voulant un jour éprouver la puissance de sa verve, l'ancêtre des griots s'en alla au bord du fleuve chanter les louanges du Lion de l'eau (la pieuvre). Celui-ci aussitôt de jeter sur la berge tous les poissons du lieu. Mais le griot continua à exciter l'animal pour en exiger d'avantage. L'autre décima la faune des ondes sans arriver à faire taire le démon de la parole. Voyant cela, il sortir des flots, vint se coucher sur le dos au pied de I'homme et mourut. Segundo Jeli-Diara, griot malinké de Guéckédou (Guiné), citado por Camara Sory. In : CAMARA, Sory. Gens de la parole: Essai sur la condition et le rôle des griots dans la société malinké. Paris: $A C C T$; Paris: Karthala; Conakry: SAEC, 1992. p. 188.
} 
- Le prince do Horodougou, le dernier legitime Doumbouya, s'ajoute à nous... quelque peu tard.

- Un retard sans inconvénient; les coutumes et les droits des grandes familles avaient été respectés; les Doumbouya n'avaient pas été oubliés, les princes du Horodougou avaient été associés avec les Keita. ${ }^{181}$

Fama é duplamente desrespeitado e humilhado: em primeiro lugar, pelo tom irônico que, de certo modo, revela que sua ausência não havia causado qualquer transtorno e, em segundo, pela afronta de associá-lo aos Keita, outro ramo do grande grupo dos Mandenka, reis do Ouassoulou e não do Horodougou. No entanto, essa conduta ressalta ainda um aspecto não negligenciável do comportamento do griot malinké: trata-se do prazer que sente ao infringir as regras de boas maneiras, fazendo uso freqüente de provérbios ousados e de expressões de baixo calão. (CAMARA, 1992, p. 184).

Além da tentativa de defender a própria dignidade, a reação de Fama frente ao insulto tem a função de mostrar a ideologia do romance:

Bâtard de griot! Plus de vrai griot; les réels sont morts avec les grands maîtres de guerre d'avant la conquête des Toubabs. Fama devait prouver sur place qu'il existait encore des hommes qui ne tolèrent pas la bâtardise. ${ }^{182}$

A constatação do desaparecimento dos verdadeiros griots não poderia deixar de ser associada à colonização por duas razões: a primeira se refere ao universo íntimo do personagem que vive presencialmente na capital, mas não se recupera das perdas do passado, atribuídas à devastação que o homem branco causou na sociedade tradicional africana; a segunda, que modela a primeira, refere-se ao intuito do autor de estigmatizar a penetração colonial. Talvez seja esta também a razão que o levou a exibir um griot tão insolente na capital e um outro, Diamourou, tão respeitoso e cortês no Togobala de sua infância. Essa é uma das técnicas do romancista a serviço de um

\footnotetext{
${ }^{181}$ KOUROUMA, LsdI, op. cit., p. 13.

182 KOUROUMA, LsdI, idem, p. p. 14.
} 
posicionamento político: o jogo de omissões - no caso, a existência de griots insolentes antes da chegada do homem branco - que reforça a imagem idílica da África pré-colonial para enfatizar a separação entre o passado ideal, e irremediavelmente perdido, e a desintegração atual do continente assolado pela herança nefasta do colonizador. Concluímos portanto que, quando Fama afirma que "os verdadeiros griots estão mortos", ele não se refere ao griot da família Doumbouya, de quem, aliás, traça um perfil relativamente simpático:

... le vieux griot avait été soigneusement conservé et séché. Tout serein et blanc, brillant comme rarement on en rencontre dans le Horodougou, maigre, mais de la bonne maigreur de l'âge, le crâne ras, quelques rides sur la nuque, sous les pommettes et sur le front, des yeux brillants au milieu des cils, sourcils et favoris blancs comme le duvet du héron du boeuf. Des mots rapides, une intelligence bouillonante. En vérité, la sérénité qu'Allah réserve à quelques vieux parmi les meilleurs croyants, les élus. Un griot, un homme de caste... ${ }^{183}$

A descrição física de Diamourou contrasta diretamente com a do feiticeiro Balla ${ }^{184}$ :

Soudain une puanteur comme l'approche de l'anus d'une civette : Balla le vieil affranchi était là. Gros et gras, emballé dans une cotte de chasseur avec des débordements comme une reine termite. Et aveugle: on guida ses pas hésitants de chiot de deux jours et le fit asseoir à droite de Fama. Des mouches en essaims piquaient dans ses cheveux tressés et chargés de gris-gris, dans les creux des yeux, dans le nez et les oreilles. Doucement le vieillard souleva l'éventail en queue d'éléphant

183 KOUROUMA, LsdI, idem, p. 109.

${ }^{184}$ Em Sémiologie du corps romanesque dans Les soleils des Indépendances, d'Ahmadou Kourouma, Gerard Dago Lézou, Jean Derive e Joseph MLanhoro fazem um levantamento das partes do corpo humano reagrupando-as em função do teor semântico de cada uma delas, bem como das conotações que remetem a importantes referentes da cultura malinké. No capítulo "Le corps romanesque comme lieu symbolique et métaphorique", Gérard Dago Lézou analisa as referências ao corpo humano como local de imagens simbólicas a partir das quais o autor produz informação indicial, reportando-se ora ao código universal, ora ao código malinké. Em "La gestuelle dans Les soleils des Indépendances", a função referencial da ação e da atividade corporal dos personagens é estudada por Jean Derive a fim de estabelecer as redes de significação que revelam, além dos códigos universal e malinké, um outro código particular de comunicação: o do autor. Neste trabalho específico constatamos, mais uma vez e sob outro ângulo, os limites que a língua francesa impõe na criação literária. (LEZOU, Gérard Dago et al. Sémiologie du corps romanesque dans Les soleils des Indépendances, d'Ahmadou Kourouma. Abidjan: EDUCI, 2002). 
et d'un bras énergique les cueillit en grappes. Les mouches jonchèrent le sol. ${ }^{185}$

Os olhos brilhantes de Diamourou se opõem diametralmente aos de Balla, fundos e cheios de moscas. Mas o crédito da boa aparência e saúde do griot é dado a Matali, sua filha e concubina de um comandante branco que não deixou faltar nada ao griot dos Doumbouya em tempo algum, mesmo durante os períodos mais difíceis das Independências e do partido único (KOUROUMA, LsdI, p. 107). Esse laço de Diamourou com os colonizadores é silenciado por Fama a favor do retorno momentâneo da sensação de habitar um mundo legítimo trazido por aqueles que vieram saudar a chegada de Fama no Togobala e pelo discurso do griot:

Les Kouyaté, les Konaté, les Diabaté, tous avaient un lien de parenté. Les aïeux de toutes ces familles avaient été introduits sous tel ou tel Doumbouya. Le griot Diamourou était intarissable et savant.

Et Fama trônait, se rengorgeait, se bombait. Regardait-il les salueurs? A peine! Ses paupières tombaient en vrai totem de panthère et les houmba! jaillissaient. Au petit de ce matin d'harmattan, au seuil du palais des Doumbouya, un moment, pendant un moment, un monde légitime plana. Les salueurs tournaient. Fama tenait le pouvoir comme si la mendicité, le mariage avec une stérile, la bâtardise des Indépendances, toute sa vie passée et les soucis présents n'avaient jamais existé. Le griot débitait comme des oiseaux de figuiers. ${ }^{186}$

O griot do Togobala é poupado pela condescendência do narrador, que se une a Fama para silenciar o compromisso de Diamourou com o homem branco e ressaltar o aspecto digno do griot dos Doumbouya. Mas nenhuma complacência é suficiente para dissimular a perda de prestígio do griot, pois, apesar de apresentar um discurso competente, o Horodougou e o Togobala de sua infância não existem mais. Portanto, não existem mais heróis a serem exaltados, jovens príncipes a serem instruídos, mitos a serem rememorados ou reis a serem aconselhados. Os heróis ficaram nos tempos imemoriais da história; a descendência foi eliminada com a esterilidade de Fama; os mitos

\footnotetext{
${ }^{185}$ KOUROUMA, LsdI, idem, p. 110.

${ }^{186}$ KOUROUMA, LsdI, idem, p. 110.
} 
fundadores, deslocados para a lembrança pessoal do personagem principal ( $p$. 97-100); e os reis perderam seu trono sagrado ${ }^{187}$ e sua função. Embora Diamourou exerça ainda esta última função de conselheiro, sua eloqüência se perde com a sobreposição da fragilidade material aos argumentos:

Comme héritage, rien de pulpeux, rien de lourd, rien de gras. Même une poule épatée pourrait faire le tour du tout. Huit cases debout, debout seulement, avec des murs fendillés du toit au sol, le chaume noir et vieux de cinq ans. [...] L'étable d'en face vide; la grande case commune [...] ne se souvenait même pas de l'odeur du pissat. Entre les deux, la petite case des cabrins: trois bouquetins, deux chèvres et un chevreau faméliques et puants destinés à être égorgés aux fétiches de Balla. E fait d'humains, peu de bras travailleurs. Quatre hommes dont deux vieillards, neuf femmes dont sept vieillottes refusant de mourir. Deux cultivateurs! [...] Et les impôts, les cotisations du parti unique et toutes les autres contributions monétaires et bâtardes de l'indépendance, d'où en tirer? En vérité Fama ne tenait pas sur du réel, du solide, du définit.... ${ }^{188}$

A necessidade de reforço da imagem idílica do Horodougou surge ainda na evocação dos griots que vieram prestar homenagem durante os funerais de Lacina, o primo que usurpou o poder da Fama e aderiu ao sistema de organização política da colonização.

Tous les griots furent abondants et intarissables, même les plus minables, car chacun connaissait la généalogie et les exploits des Doumbouya dans le Horodougou. Vint le moment des présents; chaque famille en offrit. ${ }^{189}$

Mais uma vez, Fama releva uma falha para enaltecer as virtudes do griot da África tradicional. Quando aponta a insolência do griot da capital sabemos, pela situação de afronta e pelo diálogo, que o personagem principal veicula a sua indisposição com tudo o que se refere à capital, às independências e à

\footnotetext{
187 Mais do que símbolo de poder, o trono representa ainda a ligação entre o mundo dos vivos de dos mortos, e o rei, a alma do povo e o representante do criador. (AMON D'ABY, 1998, op. cit., p. 16). Em outros termos, a queda do trono também implica a ruptura com o mundo dos mortos e a proteção dos ancestrais.

188 KOUROUMA, LsdI, idem, p. 106-107.

${ }^{189}$ KOUROUMA, LsdI, idem, p. 141.
} 
bastardia generalizada por influencia do europeu. No caso dos griots de Togobala, a descrição do narrador onisciente alia personagem, narrador e autor por meio da idealização dos costumes da tradição. No estágio de desenvolvimento atual, o escritor escreve em nome de suas próprias aspirações e compromissos ideológicos. Não tendo compromisso com as opiniões oficiais, expressa livremente seu julgamento a respeito dos personagens ou dos índices referenciais da realidade que the serviram de inspiração.

As antigas atribuições e funções do griot da tradição não encontram, portanto, nenhum respaldo na realidade imediata da ficção, mas suas perdas, como vimos, não são definitivas. No âmbito da realidade histórica, o griot desloca-se, por instinto de sobrevivência, para os grandes centros, como conselheiros dos novos governantes e intermediários nas situações de litígio. Quanto às suas habilidades e talentos como narrador, o lugar é deixado ao escritor. Assim, a exigência de fidelidade à Historia e aos mitos que dá legitimidade à narrativa e angaria o assentimento da platéia cedem lugar à imaginação e à criatividade individual, dando livre curso à demonstração de uma coletividade fraturada.

Em Les soleils des Indépendances, a recuperação da cultura tradicional não tem a função exibir a degradação de uma identidade coletiva e a separação do personagem principal da única comunidade que considerava legítima. Dentro desse contexto, é compreensível a cisão da personalidade do antigo griot malinké. Kourouma reserva os traços negativos do griot para o personagem da capital, enquanto abranda as fraquezas do griot do Togobala, um recurso que serve ao objetivo político do autor e se encaixa no eixo paradigmático de construção do romance. 


\subsection{Das unidades autônomas aos fragmentos dependentes}

Um dos elementos que destacamos ao analisar a narrativa tradicional foi a exibição de quadros sucessivos, relativamente autônomos, que se desenvolvem segundo uma progressão cronológica linear. Na passagem da oralidade ao suporte escrito, o modelo ocidental e a recepção diferida promovem alterações significativas na forma arquitetônica da obra. Assim, a narrativa passou das unidades autônomas, e aparentemente independentes, aos fragmentos que se organizam segundo a expressão do sujeito criativo.

A exposição em quadros da narrativa tradicional obedecia a uma ordenação de cenas sucessivas que correspondia a uma progressão dramática bem determinada, o que se fazia sob estrita vigilância do público. Na verdade, a ordenação desses quadros atendia e obedecia às exigências da audiência que desempenhava, ao mesmo tempo, o papel de crítico e censor. Além disso, como vimos anteriormente, as histórias narradas eram bem conhecidas e a fidelidade à biografia dos personagens e suas ações estavam na base da própria estrutura composicional das narrativas. Assim, antes de desenvolver a ação dramática, os griots, guardiões da memória histórica e dos mitos, atestavam sua autoridade hereditária como "mestres do discurso" e expunham a genealogia dos heróis a fim de provar a fidedignidade do discurso. Com a alteração do código, os escritores deixaram de se submeter aos constrangimentos da crítica imediata, mas precisaram se subordinar ao perfil do leitor, em sua grande maioria não africano e desprovido de conhecimento sobre a cultura tradicional africana. Essa passagem do oral ao escrito impôs, então, uma sensível alteração na abertura das obras: à reivindicação de autoridade dos griots substituem-se os prólogos e advertências que instruem ora sobre a fonte, ora sobre o tema ou, ainda, sobre a biografia ou ideologia do autor. A título de exemplo, vejamos alguns exemplos.

Car I'Hommo Fullanus, I'Homme Peul, exprime. Il transmet sa pensée par tradition orale, bien sûr, mais il se sert aussi, plus souvent qu'on ne pourrait le croire, de l' écriture arabe. (...) Partout affleurent les grands 
thèmes de la condition humaine: l'amitié et l'amour, le sommeil et la mort, dans le cours de la Pulâgu - c'est-à-dire de "la manière de se comporter comme un Peul. Ethique "behavioriste», si I'on veut, fondée sur la « réserve », la « retenue », - la « honte », cette expression de la sensibilité des peuples de couleur. ${ }^{190}$

Dans ce livre c'est l'âme de l'Afrique qui parle. [...] Contrairement à ce que croient beaucoup d'Européens l'Afrique, et particulièrement cette région du Soudan où est né Badian Seydou, n'est point une terre vierge de passé. Terre de rencontres, rencontres de races, de peuples, de religion, elle a hérité d'un passé peu connu, mystérieux, que ces jeunes intellectuels s'attacheront à révéler patiemment. ${ }^{191}$

La plupart des peuples colonisés, dans leurs mouvements d'émancipation, passent par deux phases essentielles: la phase de libération et celle de séparation. [...] Les nations impérialistes aident la bourgeoisie à naître dans les pays sous-développés et à consolider sa position. ${ }^{192}$

La difficulté d'écrire ce roman n'a pas été de construire mon histoire, le problème pendant des mois a été «le moi » de Bohi Di... Etre I'un de ces centaines de millions d'hommes anonymes du Tiers Monde dont personne ne connait le visage et qui soudain murmure comme gêné de déranger le monde : «... vous ne savez rien de moi, rien, je vous prie, écoutez mon histoire, celle que je vais vous raconter... Mon nom est Bohi Di, dans ma langue natale, cela signifie « fils de la terre ${ }^{193}$

A partir desses exemplos, decerto quantitativamente irrisórios face à grande produção das literaturas africanas de língua francesa, mas, a nosso ver, indicadores da demanda da nova recepção à qual nos referimos, podemos observar que, excetuando-se o prefácio de Nokan, eminentemente político, as apresentações citadas têm um traço em comum: a "instrução" ao leitor ocidental de que as páginas que serão lidas contêm a história de homens que vivem emoções comuns a toda a espécie humana, sobre terras que "não são

\footnotetext{
190 MONTEIL, Vincent. Préface. In : HAMIDOU KANE, Cheikh. L'Aventure ambiguë. Préface : Vincent Monteil. Paris: Julliard, 2005. p. 6.

${ }^{191}$ CAMPROUX, Charles. Préface. In : BADIAN, Seydou. (1963) Sous I'orage (Kany) - suivi de La mort de Chaka. Paris: Présence Africaine, 1972. p. 9.

192 NOKAN, 1966, op. cit., p. 7.

193 FANTOURÉ, Alioum. Le cercle des tropiques. Paris: Présence Africaine, 1972, p. 7.
} 
virgens de passado". Nobres ou anônimos que levantam suas vozes gradualmente, ainda "um pouco constrangidos de perturbar o mundo".

Em Les soleils des Indépendances, Ahmadou Kourouma se abstém de introduzir seu romance para o leitor africano, mas recompensa a falta de referência inicial pelo didatismo que acompanha a narrativa e que surge desde as primeiras páginas, quando explica o comportamento da "sombra" após a morte de um malinké ou o sentido da expressão "os sóis das Independências", que significa a "era das Independências". Naturalmente, trata-se aqui de informações relativas ao código cultural malinké que não esclarecem a origem do personagem principal. No primeiro romance de Kourouma, o griot foi substituído em parte pelo escritor, em parte pelo narrador, que revela, tal como no romance ocidental, a vida íntima de seu personagem. É por meio das lembranças do passado de Fama que, na segunda parte do romance, o leitor toma conhecimento do mito fundador da dinastia Doumbouya e do oráculo que predisse o seu fim:

Réfléchis à des choses sérieuses, légitime descendant des Doumbouya! Le dernier Doumbouya! Es-tu, oui ou non, le dernier, le dernier descendant de Souleymane Doumbouya? Ces soleils sur les têtes, ces politiciens, tous ces voleurs et menteurs, tous ces déhontés, ne sont-ils pas le désert bâtard où doit mourir le fleuve Doumboya ? Et Fama commença de penser à l'histoire de la dynastie pour interpréter les choses, faire l'exégèse des dires afin de trouver sa propre destinée. ${ }^{194}$

É a focalização interna, como já havia observado Borgomano (1998, p. 29), que permite que o leitor conheça os fatos essenciais à compreensão da trama e que eram fornecidos de antemão nas narrativas tradicionais.

Com efeito, o período de crise que sucedeu às independências mostrou que a estrutura linear mais ou menos autobiográfica do romance do período colonial e sua escritura das mais clássicas se revelavam inaptas para transmitir os sentimentos e os pensamentos dos novos romancistas africanos. Então, à medida que os temas se africanizavam, a estrutura e a escritura do romance sofreram metamorfoses sucessivas, umas

${ }^{194}$ KOUROUMA, LsdI, op. cit., p. 97. 
decorrentes das outras, visando uma melhor adequação do romance à personalidade cultural africana. ${ }^{195}$

Os romances do período colonial refletiam o duplo constrangimento do autor: o de lidar com um gênero até então desconhecido das literaturas africanas e o fato se ser lido sob o crivo da velha Europa que, por meio do espelhamento ou do paternalismo perverso, dava aos escritores africanos o tom da recepção de sua obra.

\subsection{Do herói épico ao príncipe decaído}

A exemplo do que ocorre em outros romances africanos, Les Soleils des indépendances retoma o tema da espoliação e da honra que caracterizava a narrativa heróica tradicional. No entanto, uma vez que o romance moderno exige a inserção de procedimentos narrativos dos quais a literatura oral podia prescindir ${ }^{196}$, o tema que era central na narrativa heróica tradicional torna-se menos preciso pela abertura do foco e inserção de planos distintos. Desse modo, além da genealogia do herói, de suas conquistas e vitórias sobre circunstâncias nefastas impostas pelo destino, temos agora o drama interno dos personagens, a descrição de pormenores indiciais da paisagem e de fatos da nova sociedade africana - a sociedade que, pelo encontro de culturas

${ }^{195}$ En effet, la période de crise qui a suivi les indépendances a montré que la structure linéaire plus ou moins autobiographique du roman de l'époque coloniale, son écriture des plus classiques se révélaient inaptes à rendre les sentiments, les pensées des nouveaux romanciers africains. Alors au fur et à mesure de l'africanisation des thèmes, la structure et l'écriture du roman ont subi des métamorphoses successives découlant les unes des autres, visant à une meilleure adéquation du roman à la personnalité culturelle africaine. (LAVERGNE, Evelyn. Les indépendances et les métamorphoses du roman africain. In : REVUE DE LITTÉRATURE ET D'ESTHÉTIQUE NÉGRO-AFRICAINES. Institut de Littérature et d'esthétique Négro-Africaines. Abidjan : NEA, n. 4, 1982. p. 20).

${ }_{196}$ Por exemplo, a inserção de certo didatismo com relação aos dados culturais que podem, eventualmente, escapar ao leitor, a necessidade das descrições espaciais ou, ainda, as precisões com relação a dados históricos relevantes para o tema. 
distintas, deslocou o pertencimento único para a esfera da multiplicidade dos núcleos de identificação.

Comparado à Wangrin, Fama não é um personagem devidamente preparado para enfrentar os adversários; ao contrário, mostra traços de caráter que não são compatíveis com as prerrogativas de um grande herói épico; ao mesmo tempo em que se insurge contra a nova ordem das independências, deixa entrever que seria facilmente subornável caso lhe fossem conferidos alguns privilégios:

Que n'a-t-il pas fait pour être coopté ? Prier Allah nuit et jour, tuer des sacrifices de toutes sortes, même un chat noir dans un puits... [...] Les deux plus viandés et gras morceaux des Indépendances sont sûrement le sécretariat général et la direction d'un coopérative... Le secrétaire général et le directeur, tant qu'ils savent dire les louanges du président, du chef unique et de son parti, le parti unique, peuvent bien engouffrer tout l'argent du monde sans qu'un seul oeuil ose ciller dans toute I'Afrique. ${ }^{197}$

Enquanto Wangrin revela um duplo amparo obtido, por um lado, através da sua iniciação na sociedade tradicional e, por outro, com sua formação na escola francesa, Fama carrega em sua bagagem apenas os valores de uma sociedade que foi demolida, pois, para ele, seu esteio sumiu nas brumas do tempo da colonização e nada de realmente substancial pôde suprir essa perda. Desprovido dos meios que garantiam, abrilhantavam e justificavam sua existência, Fama também se vê destituído de armas para enfrentar a sua busca pela reabilitação da honra perdida. Se Wangrin consegue seguir o itinerário que lhe permite alcançar o poder político e financeiro, Fama ostenta, do início ao fim do romance, a imagem do "deserdado", do "deslocado", e daquele que não consegue resolver a questão da mesmidade, da consistência e do desenvolvimento contínuo de sua própria identidade.

Com a presença do tema da espoliação e a luta pela legitimidade que ocupam o primeiro plano no romance, encontramos um ponto de convergência entre o primeiro romance de Ahmadou Kourouma e a narrativa heróica. No

${ }^{197}$ KOUROUMA, LsdI, op. cit., p. 25. 
entanto, a busca e a luta do herói tradicional pela restituição de sua honra e de sua glória cederam lugar a uma luta estéril, na mesma proporção da esterilidade objetiva de Fama. O príncipe decaído não possui os atributos de um verdadeiro herói, nem sequer a proteção dos deuses da tradição ou o amparo de oráculos favoráveis, como no caso de Soundjata.

Fama Doumbouya, dernier et légitime descendant des princes Doumbouya do Horodougou, totem panthère (KOUROUMA, LsdI, p. 11), foi reduzido à imagem de abutre e hiena e condenado a viver dos donativos distribuídos nos funerais da capital da Costa dos Ébanos. Príncipe quase mendigo, coberto de vergonha pelo desprezo público (KOUROUMA, LsdI, p. 1317), oublié et jeté aux mouches (KOUROUMA, LsdI, p. 24-25) pela independência que sucedeu às lutas anticoloniais, só lhe resta esperar a ajuda providencial de Allah. A extensa lista de atributos de Fama aponta para a degradação do personagem que o narrador tem o cuidado de estabelecer em diversos níveis. Fisicamente, a degradação final de Fama é acentuada pelos traços do belo jovem que habita a memória de Salimata:

Elle s'était rappelé la première fois qu'elle avait vu Fama: le plus haut garçon du Horoudougou, le plus noir, du noir brillant du charbon, les dents blanches, les gestes, la voix, les richesses $d^{\prime}$ un prince. [...] Un Fama toujours unique, déclencheur du désir de le toucher, de le frôler, de l'avaler, de l'écouter. ${ }^{198}$

Em suma, um verdadeiro príncipe, educado à sombra dos griots e do Alcorão, um brilhante Dioula de boa malinkeria (RIPAULT, 1987, p. 7), que termina seus dias em verdadeira decadência e estado de abandono e decrepitude:

Fama n'était pas astreint aux travaux pénibles, mais son état de santé se dégradait. Des vers de Guinée poussaient dans les genoux et sous les aisselles. Constamment il déssechait: ses yeux s'enfonçaient dans les orbites plus profondes que des tombes, ses oreilles décharnées s'élargissaient et se dressaient proéminantes comme chez un léporide

${ }^{198}$ KOUROUMA, LsdI, idem, p. 48. 
aux aguets, les lèvres s'amincissaient et se rétrécissaient, les cheveux se raréfiaient. ${ }^{199}$

La dernière goutte du grand fleuve qui se perd et sèche dans le désert (KOUROUMA, LsdI, p.169), Fama é uma vítima da colonização e da era das independências. Despojado da cheferia pelos colonos que beneficiaram seu primo Lacina, as independências se revelaram ainda mais frustrantes para Fama do que a colonização, pois, analfabeto, não conseguiu nenhuma atribuição digna de um Doumbouya. Essa frustração é o que comandava a indignação de Fama: que os cargos de ministros, deputados e embaixadores sejam dados a outros, isso ele pode compreender, pois ler e escrever são condições fundamentais para o exercício de tais profissões. Mas quando a África descobre o partido único e, depois, as cooperativas - que acabaram com o comércio -, surgem, na opinião de Fama, muitas razões para compensar seus esforços durante as lutas pela liberação do país, mas nenhuma recompensa Ihe foi oferecida. Além da crítica à política de distribuição de cargos, Fama deplora o fato de que os postos por ele cobiçados, a secretaria de uma subseção do partido ou direção de uma cooperativa, fossem atribuídos àqueles que (...) savent dire les louanges du président, du chef unique et de son parti, le parti unique, peuvent bien engouffrer tout l'argent du monde sans qu'un Seul oeil ose ciller dans toute l'Afrique (KOUROUMA, LsdI, p. 25).. Em princípio, a crítica do personagem dirigida à corrupção dos membros da política e da gestão administrativa das independências o separa desse processo e aumenta sua dignidade. Mas enquanto o personagem se esforça em manter sua honra, o narrador se apressa em dar o tom das contradições do personagem, numa relação bastante íntima com o narratário ${ }^{200}$ :

199 KOUROUMA, LsdI, idem, p. 167.

200 Cf. SIDIBE, Charles-Adolphe. La fiction intime dans Les soleils des Indépendances d'Ahmadou Kourouma. In : Revue GELL. Sénégal : Université Gaston Berger de Saint-Louis, n. 9, jan. 2005. 
Que n'a-t-il fait pour être coopté ? Prier Allah nuit et jour, tuer des sacrifices de toutes sortes, même un chat noir dans un puits; et ça se justifiait ! ${ }^{201}$

Sob a óptica do narrador, Fama, a despeito de sua origem nobre, não representa o antigo herói das narrativas tradicionais. No seu caso, os atributos de distinção foram substituídos por traços do indivíduo comum que, acuado, reage e expressa sua ira e suas contradições. Como o suporte escrito trouxe a possibilidade de atuação do narrador onisciente que revela o drama intimo de seus personagens, podemos compreender a dimensão da desordem psíquica do indivíduo alterado pela falta de reconhecimento e, portanto, sem afiliação comunitária. Observamos ainda na citação acima uma antecipação de um dado cultural importante para a compreensão do perfil de Fama, mas que só será esclarecido posteriormente: trata-se do caráter ambíguo da personalidade malinké:

Sans la fausseté malinké, cette première nuit aurait été reposante, tel le calme d'un sous-bois rafraîchi par une source au bout d'une longue marche d'harmattan. Mais la fausseté! Les Malinkés ont la duplicité parce qu'ils ont l'intérieur plus noir que leur peau et les dires plus blancs que leurs dents. Sont-ce des féticheurs? Sont-ce des musulmains? Le musulman écoute le Coran, le féticheur suit le Koma; mais à Togobala, aux yeux de tout le monde, tout le monde se dit et respire musulman, seul chacun craint le fétiche. ${ }^{202}$

Como afirma o narrador: rituais muçulmanos ou feitiços eram justificáveis. Mas como a exposição da vida psíquica do personagem não é suficiente para solucionar todas as questões que se levantam quanto à conduta do indivíduo, resta-nos perguntar se Fama teria feito qualquer coisa para ser absorvido pela administração ou pela política das independências por traição aos princípios da tradição, por fidelidade à duplicidade malinké ou simplesmente para ser absorvido pela nova ordem e obter finalmente um reconhecimento. Tendemos a enfatizar a última alternativa, mas forçoso é

\footnotetext{
${ }^{201}$ KOUROUMA, LsdI, p. 24-25.

202 KOUROUMA, LsdI, idem, p. 105.
} 
considerar que talvez, ao fim e ao cabo, essas possibilidades não sejam excludentes, mas aceitá-las integralmente pode configurar um risco sem suporte. Em resumo, por mais que tenhamos dados que explicitam o funcionamento psíquico dos personagens, algo sempre nos escapa, a exemplo do que ocorre com o individuo na esfera do mundo real.

Les soleils des Indépendances suscitou severas críticas ${ }^{203}$ com relação ao autor, considerado reacionário por ter escolhido um príncipe como personagem principal e, como tema, a queda de uma dinastia, afastando-se assim do sofrimento da grande massa de anônimos que padeceram sob a colonização e padecem ainda sob a tirania dos governos independentes. Mas se a queda da dinastia e a agonia do protagonista podem ser consideradas como a representação da morte da tradição ${ }^{204}$, por que tal representação não poderia se estender a todos os que sofreram sob os "sóis das Independências?". Mais reacionário seria creditar a busca pela dignidade apenas aos nobres. Existe, de fato, como demonstra Bakhtin em Estética da criação verbal, uma correlação entre o autor e o herói que determina a realização do herói em sua totalidade e estabelece a percepção de dois planos de valores: o horizonte do herói e o contexto do autor-contemplador.

O autor é crítico (enquanto autor, claro): lança mão de todos os privilégios da sua exotopia completa em relação ao herói. Nessa forma de inter-relação o herói é independente, vivo, consciente e resoluto no escopo de sua vida, em seus valores éticos e cognitivos; o autor situa-se diante dessa atividade do herói e dá sua transposição em linguagem estética; cada um dos aspectos da atividade que o herói desenvolve em

203 Olympe Bhêly-Quenum, escritor beninense, criticou violentamente Ahmadou Kourouma em entrevista concedida a Mansour Diouf. Mesmo reconhecendo seu talento considera excessiva a adulação a um escritor cuja obra, na sua opinião, não justifica a comparação com Rabelais ou Voltaire. Como exemplo, cita a segunda parte de Les Soleils des Indépendances, « onde seu personagem principal, de um racismo inacreditável, ataca os Daomeanos e os Nagôs do sul, a ponto de declarar que em seu país os franceses não são responsabilizados porque é graças a eles ou à França que se tem trabalho." In: http://www.congopage.com/article3195.html

${ }^{204}$ Fato do qual discordamos anteriormente. Cf. capítulo 2, Parte III. 
sua vida encontra sua determinação artística, transcendente a essa vida. ${ }^{205}$

Como bem demonstra Evelyn Lavergne, Kourouma revela uma ternura por todas as Salimata que exalam "um cheiro de goiaba verde", por todos os Fama "transfigurados pela obsessão de alcançar a dignidade como um oxigênio necessário ${ }^{206}$, comentário que encerra os personagens do romance no prisma da representação.

Em que pese as críticas sofridas por Kourouma por ter concebido um personagem rígido e retrógrado, que não entende o foco principal das tensões e suas reivindicações giram em torno de interesses pessoais, o que temos aqui é uma concepção histórico-espacial que tem como substrato uma noção universal do abandono, daquele que busca uma durabilidade e uma essencialidade inexistentes. A duração do contexto social ao qual estava habituado, o abrigo do complexo tradicional como única via de legitimação de sua própria existência tornou-se, de fato, uma realidade caduca; e Fama não possui nada que possa assumir o papel desse remoto status quo, pois sua ação se limita, em termos políticos, a severas críticas contra os tempos das independências, o que não chega a constituir um engajamento capaz de darIhe viço e razão suficientes para ingressar na "modernidade" trazida pelos europeus. Em outras palavras, Fama vive como se a única possibilidade de recomposição de sua identidade fosse o retorno aos antigos padrões da tradição africana, o que se revela como dupla alienação do personagem: em primeiro lugar, a quimera do retorno como eliminação da falta e, em segundo, o repúdio, implícito em sua conduta, à concepção de que a identidade é uma condição eternamente provisória que não pode ser encontrada apenas em uma realidade espaço-temporal determinada, mas que, como afirma Zygmunt Bauman (2005, p. 20), só nos é revelada como algo a ser descoberto.

205 BAKHTIN, Mikhail. Estética da criação verbal. Tradução feita a partir do francês: Maria Ermantina Galvão G. Pereira. 2. ed. São Paulo: Martins Fontes, 1997. p. 188. 206 ... [une] tendresse pour toutes les Salimata qui exhalent « une senteur de goyave verte », pour tous les Fama « transfigurés par (leur) acharnement à vouloir la dignité comme un oxygène nécéssaire. (LAVERGNE, 1982, op. cit., p. 22). 
Roger Caillois (1972) aponta a diferença fundamental que existe entre o herói mítico africano e o herói mítico ocidental, creditando a este o poder de atuar como meio de compensação da alma humilhada do indivíduo que, bloqueado psicologicamente, delega o herói em seu lugar.

O romance expõe os infortúnios de Fama Doumbouya, personagem que não se adapta às mutações na África das independências e sua hostilidade frente à colonização é devida à luta pela legitimidade, a exemplo da temática fundamental da narrativa heróica tradicional. No entanto, o grande obstáculo a sua reabilitação encontra-se na desproporção entre sua missão e os meios de que dispõe para realizá-la: a legitimidade da luta que, outrora, era sustentada pela estrutura social tradicional não encontra mais uma base sólida sobre a qual possa se apoiar, ou seja, não é reconhecida ou ratificada senão pelo próprio herói e por alguns personagens enfraquecidos da trama, como o griot Diamourou e o feiticeiro Balla, o que torna a busca e o combate de Fama estéreis, grotescos e, por conseguinte, dignos de escárnio.

Embora esta tenha sido a apreensão de boa parte da crítica relativa a Les soleils des Indépendances, a denúncia das relações de força entre colonizadores e colonizados que resultou na queda da aristocracia feudal e ascensão da burguesia africana seria, como aponta Maryse Condé, uma maneira um tanto simplista de considerar o romance de Ahmadou Kourouma. Apontando essa interpretação como uma visão excessivamente sociológica que restringe o alcance deste "belo romance", Condé (1977:28) apresenta Fama como o personagem que parece representar a África Antiga, com nobres e plebeus reunidos, que não compreende os novos modos de vida, as novas formas de poder, as contradições dos novos regimes instaurados pelas independências e para quem a única saída é a morte.

Como podemos observar, existe uma certa complementaridade no modo como Mohammadou Kane e Maryse Condé apreciam o perfil do personagem principal de Les soleils des Indépendances, que reforça a nossa perspectiva de análise da obra e do personagem. Enquanto o primeiro se refere à inadaptação de Fama às mutações ocorridas na África das independências, Condé aponta a 
incompreensão do herói no que se refere aos novos modos de vida, às novas formas de poder e contradições dos novos regimes instaurados pelas independências. Dois pontos de vista parcialmente distintos e, ao mesmo tempo, complementares, que servem de base para a noção em torno da qual se estrutura a nossa proposta de análise do romance, ou seja, o estudo do perfil e do comportamento de Fama sob a perspectiva da representação do indivíduo que se vê subtraído da única comunidade que justifica seu sentimento de pertença e não encontra na nova ordem estabelecida nenhum sentido que permita uma nova ancoragem ou a possibilidade de uma reacomodação. Fama cresceu sob a tutela da Tradição, cujo princípio de organização repousava na hierarquia e no comando coercitivo da comunidade que sustentava a estrutura e coibia os desvios; dentro do universo de imobilidade social que caracteriza uma estrutura hierárquica, Fama ocuparia um lugar de prestígio caso a colonização e, posteriormente, as independências não the tivessem subtraído as posses, o poder ou ainda as duas atividades dignas de um Malinké: as guerras e o comércio. A incompreensão e a inadaptação de Fama aos novos padrões que se instalaram com a chegada dos toubabs fazem de Fama mais do que o representante do desaparecimento da antiga elite dos chefes e, por conseguinte, da África Tradicional. Submetido à arbitrariedade dos novos poderes e constrangido a viver subordinado a um conjunto de regras cujas conseqüências empíricas não fazem o menor sentido para ele, Fama, o príncipe Doumbouya, pleiteia o reconhecimento de suas credenciais e a submissão dos demais à sua agora suposta autoridade. À frustração de sua demanda seguem-se o alheamento e a loucura ${ }^{207}$ como forma de suplantar a perda de marcas substanciais de sua identidade, pois:

207 O alheamento e a loucura são aqui considerados do ponto de vista do excesso, nas reações de Fama. Mas é preciso observar que, uma certa violência nas reações de coação é atributo da própria personalidade malinké. A esse respeito, Camara Sory esclarece: Na mentalidade dos malinkés, uma mesma ligação simbólica reúne, ao mesmo tempo, a mulher, a água enquanto imagem da onda invasiva de uma emoção debilitante, a idéia da fraqueza e da impotência. A mulher não é livre para expressar todas as emoções, inclusive, e sobretudo, a gama dessa afetividade úmida representada pela compaixão, em geral kìnìíní, pela piedade, màñumàkó e pelo 
... nossa identidade é em parte moldada pelo reconhecimento ou pela falta deste; às vezes também pelo falso reconhecimento de outros, e assim, um indivíduo ou um grupo de pessoas pode sofrer um verdadeiro dano, uma autêntica deformação se as pessoas ou a sociedade que o rodeiam the mostram, como reflexo, um quadro limitativo, ou degradante ou depreciativo de si mesmo. O falso reconhecimento pode causar dano, pode ser uma forma de opressão que aprisione alguém em um modo de ser falso, deformado e reduzido. ${ }^{208}$

\subsection{Da mulher africana aos costumes ligeiros}

O fracasso econômico e social de Fama é também acompanhado pelo fracasso familiar. Embora as conseqüências para cada um sejam bastante distintas, Fama divide com Salimata a frustrante experiência da esterilidade. Salimata ocupa um espaço bastante significativo da narrativa, o que faz com que a ficção se organize, portanto, em torno de dois destinos paralelos. A primeira parte do romance é composta de quatro subdivisões, dentre as quais duas são inteiramente dedicadas a Salimata e uma contém uma parte substancial de seu perfil, exibido por meio dos questionamentos e lembranças de Fama. Considerando-se a importância atribuída ao personagem, somos levados a considerar o grau de generosidade do autor com relação à primeira esposa de seu protagonista. Nos romances subseqüentes, a mulher ocupa um

medo, sílá. Um nobre deve afastar-se de todas essas coisas e desenvolver sua coragem bélica e sua cólera como antídotos. [Dans la mentalité des Malinké, un même lien symbolique réunit à la fois la femme, l'eau en tant qu'image de la vague invahissante d'une affectivité débilitante, l'idée de la faiblesse et de l'impuissance. La femme n'est-elle pas libre d'exprimer toutes les émotions, y compris et surtout la gamme de cette affectivité humide que représentent l'atendrissement en général kìnikíní, la pitié, màñùmàkó et la peur, sílá]. (CAMARA, 1992, op. cit., p. 96).

208 ... nuestra identidad se moldea em parte por el reconocimiento o por la falta de este; a menudo, también, por el falso reconocimiento de otros, y así, un individuo o un grupo de personas puede sufrir un verdadero daño, uma auténtica deformación si la gente o la sociedad que lo rodean le muestran, como reflejo, un cuadro limitativo, o degradante o depreciable de si mismo. El falso reconocimiento o la falta de reconocimiento puede causar daño, puede ser uma forma de opresión que aprisione a alguien em un modo de ser falso. Deformado y reducido. (TAYLOR, 2001, op. cit., p. 43-44). 
espaço bem menos relevante para o conjunto da ação. Em Monnè, outrages et défis, apenas o décimo capítulo aborda a situação feminina, pois o período enfocado pela obra abrange uma sociedade na qual as mulheres não tomam a palavra, uma sociedade que repousa sobre o silêncio das mulheres. ${ }^{209}$ (BORGOMANO, 1998, p. 201). O próprio título do capítulo é bastante significativo em termos de referência cultural: Dans ce monde, les lots des femmes sont trois noms qui ont la même signification: résignation, silence, soumission (KOUROUMA, 1990, p. 29). Em En attendant le vote des bêtes sauvages, com exceção de Nadjouma, mãe do ditador Koyaga, as mulheres são numerosas, mas permanecem em segundo plano.

Salimata pode ser considerada, sob alguns aspectos, como representante da mulher africana, a força secreta dos homens e do continente africano (BRAHIMI E TREVARTHEN, 1998, p. 7), que em determinados momentos, ajuda o homem a vencer suas batalhas e fazer suas conquistas. De fato, no caso de Salimata, seu marido não está empenhado em nenhuma luta que exija sua participação, mas é às suas expensas que Fama sobrevive e suporta sua situação social medíocre na capital:

Un vaurien comme une crotte, vide la nuit comme le jour, pour lequel elle se cassait, se levait au premier chant du coq, préparait et vendait la bouillie pour avoir de l'argent pour le nourrir, pour le vêtir, pour le loger, et à midi courir le marché, le plateau, vendre du riz et avoir de l'argent pour les sortilèges, les médicaments, les marabouts et les sacrifices qui doivent procurer la virilité et la fécondité... Et la nuit ne connaître, ne recevoir que les ruades d'âne. ${ }^{210}$

Muitas mulheres africanas possuem um pesado fardo em suas atividades quotidianas, no entanto, é preciso considerar a diversidade de perfis que dificulta a criação de uma mulher modelo, pois como apontaram Brahimi e Trevarthen, os grandes contrastes dos povos e agrupamentos étnicos não permitem a criação de modelos reducionistas:

209 ... une société où les femmes n'ont pas la parole, une société qui repose sur le silence des femmes. (BORGOMANO, 1998, op. cit., p. 201).

210 KOUROUMA, LsdI, op. cit., p. 35-36. 
Como dominar sua diversidade enquanto as vemos ora como poderosas e influentes, reconhecidas e veneradas, ora miseráveis e mais vítimas do que a Justina, de Sade, ora em luta, conseguindo aqui e acolá alguns avanços, a despeito de difíceis obstáculos a superar? ${ }^{211}$

Se não é possível sintetizar em um único perfil a diversidade das mulheres africanas, Kourouma consegue, ao menos, concentrar em Salimata algumas características comuns às mulheres do continente, ou seja, a importância da maternidade como meio de reconhecimento social, a concepção da mulher como objeto de prazer e, conseqüentemente, como ser inferior na escala hierárquica africana, ocupando, ao lado das crianças, o ultimo nível de importância:

Depois dos gênios vêm os ancestrais, todos aqueles que viveram uma vida normal que, uma vez mortos, tornaram-se poderosos no outro mundo. Do outro lado, eles também têm uma hierarquia já que lá o rei continua sendo rei. Mas com relação aos vivos, os ancestrais sempre são mais poderosos ; depois dos ancestrais vêm os velhos, os anciãos (...). Depois vêm os homens, os jovens, os homens comuns, as mulheres e as crianças. ${ }^{212}$

No caso específico da mulher malinké, alguns traços recenseados por Camara Sory (1992) contribuem para a compreensão do perfil de Salimata. Dentre os mais relevantes para o nosso propósito, selecionamos o espaço que a mulher ocupa em relação ao universo masculino, a desconfiança e temor dos homens com relação ao que se considera uma espécie de "incontinência

211 Comment maîtriser leur diversité, alors qu'on les voit tantôt puissantes et influentes, reconnues et vénérées, tantôt misérables et plus victimisées que la Justine de Sade, tantôt en lutte et en réalisant ici ou là quelques avancées, en dépit d'obstacles lourds à soulever ? (BRAHIMI, Denise; TREVARTHEN, Anne. Les femmes dans la littérature africaine: Portraits. Préface: Catherine Coquery-Vidrovitch. Paris: Karthala; Abidjan: CEDA, 1998. p. 8).

${ }^{212}$ Après les génies vient les ancêtres, tous ceux qui sont passés par la vie normale et qui étant morts sont devenus des puissances dans l'autre monde; là-bas aussi ils ont une hiérarchie puisque le roi reste roi là-bas. Mais par rapport aux vivants les ancêtres sont toujours plus puissants; après les ancêtres vient les vieux, les anciens (...). Viennent donc les hommes, les jeunes, les hommes ordinaires, les femmes et les enfants. (ZADI ZAOUROU, Bernard. Bernard Zadi Zaourou: Depoimento [mar. 2006]. Entrevistadora: Maria Suzana Moreira do Carmo. Abidjan, 2006). 
verbal" e a agressividade; esta, na verdade constitui apenas um traço feminino, pois a violência é um dos atributos da personalidade malinké. Mesmo que este não seja um traço específico da mulher malinké, sua repercussão no comportamento feminino se liga diretamente a uma peculiaridade malinké: a desconfiança dos homens com relação à indiscrição e agressividade verbal da mulher. Condenadas ao silêncio e postas à margem da sociedade, as mulheres desenvolvem o artifício da indiscrição, levando assim os homens a um certo temor no trato com suas companheiras e ao inevitável afastamento. Uma outra conseqüência imediata desse temor do homem com relação à mulher é busca da cumplicidade fora do lar.

A organização social reserva às mulheres uma posição que não the permite nenhuma participação direta nas decisões que concernem a vida social, pública e política; assim, cabe à mulher a execução dos afazeres domésticos e os cuidados com a prole. Manter as mulheres longe das comunidades masculinas tem pour objetivo reforçar o status e a autoridade dos homens. As relações familiares são regidas, antes de tudo, por relações de hierarquia e de autoridade que excluem, por essa razão, a familiaridade que a camaradagem implica ${ }^{213}$. Além disso, na concepção dos malinkés, o contato freqüente com as mulheres pode representar uma perda de energia que pode comprometer outras atividades do homem.

Submissa a esses constrangimentos sociais, Salimata representa a condição de "milhares de mulheres de condição modesta" e, além disso, tratase de uma mulher:

... traumatizada por muitos ferimentos corporais (excisão, estupro, seqüestro) e pela esterilidade, mas decidida a se assumir e a se integrar em um contexto socioeconômico ao qual seu marido não consegue se adaptar. ${ }^{214}$

213 Les relations familiales sont régies avant tout par des rapports de hiérarchie et d'autorité excluant de ce fait la familiarité qu'implique la camaraderie. (CAMARA, 1992, op. cit., p. 62).

214 ... traumatisée par maintes blessures corporelles (excision, viol, séquestration) et la stérilité, mais décidée à s'assumer et à s'intégrer dans un contexte socio-économique auquel son mari ne parvient pas à s'adapter. (TRAORÉ, Aminata. Les femmes 
A integração de Salimata ao novo contexto da vida na capital é o que diferencia seu comportamento das reações de Fama, pois a dupla cultura pode ser fonte de renovação ou de alienação. Como não cabe às mulheres imiscuirse das decisões políticas e sociais, sua adaptação às novas circunstâncias não constitui, na verdade, um ato deliberado, mas o meio de realizar o ideal feminino que conhece. Como vimos acima, as atividades domésticas fazem parte das ocupações habituais da mulher e o trabalho remunerado de Salimata no mercado tem o objetivo de alimentar o marido e cobrir as despesas com os sortilégios, os marabus, e os sacrifícios a fim de trazer a fertilidade (p. 35-36). Portanto, suas preocupações giram em torno do cumprimento de suas obrigações e da eliminação da esterilidade. Preces, sortilégios e convulsões rituais, tudo na vida de Salimata gira em torno da tentativa de ter um filho e dar uma atribuição mais digna a un ventre sans épaisseur, ne couvrant qu'entrailles et excréments (KOUROUMA, LsdI, p. 33).

A esterilidade tem, no entanto, significados distintos para ambos ${ }^{215}$; enquanto Salimata pretende atender a uma exigência que define uma identidade social ${ }^{216}$, Fama preocupa-se com a sua descendência e possível continuação da dinastia. Para Salimata não se cogita sequer a recompensa de uma criança dieudonné (N'DA K., 1984, p. 86), a criança que ninguém viu nascer e que chega ao vilarejo como um milagre ou o presente de um deus ou um gênio complacente feito a uma mulher estéril. Como afirma J.-P.

ivoiriennes dans la parole. In: NOTRE LIBRAIRIE: Revue du livre Afrique noire, Maghreb, Caraïbes, Océan Indien. Littérature de Côte d'Ivoire I: La Mémoire et les mots. Paris : Clef, n. 86, jan.-mars 1987. p. 106).

215 Tal distinção não elimina o significado e a importância do filho como fator de reconhecimento social para ambos: Ce qui sied le plus à un ménage, le plus à une femme: l'enfant, la maternité qui sont plus que les plus riches parures, plus que la plus éclatante beauté ! A la femme sans maternité manque plus que la moitié de la féminité. (KOUROUMA, LsdI, p. 52)

216 Entre os prejuízos irreversíveis sobre a saúde da mulher, recenseados pela medicina na luta atual contra a excisão, encontra-se, dentre outros, a esterilidade. Embora Salimata seja apontada como estéril, em nenhum momento se cogita essa agressão física como origem provável de seu problema. Cf. KAUDJHIS-OFFOUMOU, Françoise ; NKIRANUYE, Jean Emile. L'excision en question. In : DÉBATS : Courrier de I'Afrique de l'Ouest. Abidjan : CERAP/ Inades, n. 32, fév. 2006. p. 15-20. 
GOURDEAU (1977, p. 72), se a esterilidade é para Fama uma grande preocupação, para sua esposa, ela é uma obsessão intolerável, que chega a provocar alucinações ${ }^{217}$.

Além da divergência dos objetivos da procriação, a falta de cumplicidade do casal se evidencia pelo modo como tentam eliminar a esterilidade. Fama, como bom muçulmano, recorre às preces e invocações a Alá:

Fama devait prier pour détourner, écarter une vie semblable à une journée à l'après-midi pluvieux. Une vie qui se mourait, se consumait dans la pauvreté, la stérilité, I'Indépendance et le parti unique! $!^{218}$

Para Salimata nenhum sacrifício é demasiado para eliminar a maldição da esterilidade. Mesmo fazendo suas orações e se comportando como uma boa muçulmana (KOUROUMA, LsdI, p. 28), entrega-se aos rituais mais extravagantes, a ponto de levantar as suspeitas do marido quanto a sua integridade religiosa:

L'intérieur de Fama battait trouble. Qui pouvait le rassurer sur la pureté musulmane des gestes de Salimata? Trépidations et convulsions, fumées et gris-gris, toutes ces pratiques exécutées chaque soir afin que le ventre fécondât ! $!^{219}$

217 ... Si la stérilité est pour Fama une préoccupation majeure, elle est pour son épouse une obsession intolérable, qui va jusqu'à provoquer des hallucinations. (GOURDEAU, J.-P. Les religions. In : M'LANHORO, Joseph. (org.) Essai sur Les soleils des indépendances. Abidjan: NEA, [1974]. p. 72). Gourdeau refere-se às alucinações que levavam Salimata a sentir efetivamente a presença física do filho tão desejado : Et les pensées de Salimata, tout son flux, toutes ses prières appelèrent des bébés. Ses rêves débordaient de paniers grouillants de bébés, il en surgissaient de partout. Elle les baignait, berçait et son coeur de dormeuse gonflait d'une joie chaude jusqu'au réveil. En plein jour et même en pleine rue, parfois elle entendait des cris de bébés, des pleurs de bébés. Elle s'arrêtait. Rien : c'était le vent qui sifflait ou des passants qui s'interpellaient. Un matin, elle rinçait les calebasses; sous ses doigts elle sentit un bébé, un vrai bébé. Elle le baigna, il pleurait en gigotant. Elle le porta dans la chambre et ouvrit les yeux. Rien : une louche dure et cassante. Et Salimata debout avec ses hontes et ses désespoirs. Une nuit, dans le lit, un bébé vint se coller à Salimata et se mit à la têter, les succions ont brûlé les seins gauche et droit, elle le tâta, tout chaud, tout rond, tout doux. Elle alluma la lampe : envolé, transformé en mortier de cuisine. (KOUROUMA, LsdI, p. 52).

${ }^{218}$ KOUROUMA, LsdI, p. 31.

${ }^{219}$ KOUROUMA, LsdI, p. 29. 
Salimata mistura versículos do Alcorão a infusões de toda espécie, a malabarismos febris, cantos e urros demoníacos até a exaustão ou semiconsciência. Apesar de não ser totalmente favorável aos artifícios patéticos de sua esposa, Fama cumpre seu dever de marido por medo das reações violentas de Salimata:

Sur-le-champ, même rompu, cassé, bâillant et sommeillant, même flasque et froid dans tout le bas-ventre, même convaincu de la futilité des choses avec une stérile, Fama devait jouer à l'empressé et consommer du Salimata chaud [...] sinon les orageuses et inquiétantes fougues de Salimata! Elle s'enrageait, déchirait, griffait et hurlait : «Le stérile, le cassé, l'impuissant, c'est toi ! »220

A violência e a agressão com traços típicos da personalidade malinké também atinge as mulheres. Sua submissão, em geral aparente, não impede em absoluto tal atitude. Não é raro vê-las afrontar deliberadamente os golpes de um marido furioso gritando, com todas as suas forças o que há de mais profundo em seu pensamento. Daí as cenas particularmente violentas ${ }^{221}$. Quanto à ineficácia dos fetiches, o descrédito de Fama segue a norma da boa conduta muçulmana e é apenas aparente, pois, quando se encontra no Togobala, Fama não se priva da proteção de práticas contraditórias e, a priori, incompatíveis:

Sans la fausseté malinké, cette première nuit aurait été reposante, tel le calme d'un sous-bois rafraîchi par une source au bout d'une longue marche d'harmattan. Mais la fausseté! Les Malinkés ont la duplicité parce qu'ils ont l'intérieur plus noir que leur peau et les dires plus blancs que leurs dents. Sont-ce des féticheurs? Sont-ce des musulmains? Le musulman écoute le Coran, le féticheur suit le Koma; mais à Togobala, aux yeux de tout le monde, tout le monde se dit et respire musulman, seul chacun craint le fétiche. [...] Le Coran dit qu'un décédé est un appelé par Allah, un fini; et les coutumes malinké disent qu'un chef de famille couche dans la case patriarcale. Il n'y avait ni hésitation ni

\footnotetext{
220 KOUROUMA, LsdI, p. 30.

${ }^{221}$ Leur soumission, souvent apparente, n'empêche nullement une telle attitude. II n'est pas rare de les voir affronter délibérément les coups d'un mari furieux en criant de toutes leurs forces le fond de leur pensée. D'où des scènes particulièrement violentes. (CAMARA, 1992, op. cit., p. 188).
} 
palabre, la grande case patriarcale vide après le décès du cousin était là, elle avait abrité tous les grands aïeux Doumbouya [...] Mais chez les Bambaras, les incroyants, les Cafres, on ne couche jamais dans la case d'un enterré sans le petit sacrifice qui élogne esprits et mânes. [...] Et le malheur qui doit suivre la transgression d'une coutume intervient toujours, intervient sûrement, si par la parole le fautif avait été prévenu de l'existence de la coutume, surtout quand il s'agit de la coutume d'un village de brousse. ${ }^{222}$

Em "Povo e cultura malinké" vimos que, a exemplo do que ocorreu com o cristianismo no passado recente da colonização, a ascendência árabe se impôs à cultural local, mas que, na prática, os códigos religiosos, morais e políticos do Alcorão precisaram adaptar-se à cultura e às crenças locais. Assim,

O temor ao fetiche é tão forte que as crenças e formas de culto importadas não conseguem destruí-lo. O fetiche continua sendo a representação sensível de poderes invisíveis capazes de regularizar ou de perturbar o curso de toda uma vida. ${ }^{223}$

As práticas contraditórias dos malinkés representam, de fato, 0 fenômeno da transculturação, o resultado dinâmico da "negociação" entre culturas que implica, necessariamente, a conservação de aspectos consistentes da cultura anterior.

Um exemplo dessa permanência encontra-se na novela L'étonnante et dialéctique déchéance du camarade Kali Tchikati, de Emmanuel Dongala, cujo personagem principal, de formação marxista-leninista, acaba cedendo, por força das evidências, à constatação da existência dos poderes invisíveis. Kali, depois de ter se casado com uma mulher de outra etnia e, portanto, não aceita por sua comunidade, é amaldiçoado pelo tio que lhe faz um feitiço para que não possa procriar com a mulher que escolheu como esposa. As convicções filosóficas e políticas de Kali não permitem que dê ouvidos ao que considera

\footnotetext{
222 KOUROUMA, LsdI, p. 105-106.

${ }^{223}$ La crainte du fétiche est si forte que les croyances et les formes de culte importées ne parviennent pas à l'éroder. Le fétiche reste la représentation sensible des puissances invisibles capables de régulariser ou de perturber le cours de toute une vie. (DAILLY, Christophe. Devins et guérisseurs dans la littérature négro-africaine. In: REVUE DE LITTÉRATURE ET D'ESTHÉTIQUE NÉGRO-AFRICAINES. Institut de Littérature et d'esthétique Négro-Africaines. Abidjan : NEA, n. 4, 1982, p. 69).
} 
crendices de um velho dont le raisonnement n'avait même pas atteint um développement pré-marxiste (DONGALA, 1982, p. 15). O resultado de sua incredulidade custaria a sua mulher uma situação semelhante à de Salimata:

Mais voilà que marié depuis plus de deux ans je n'avais pas d'enfant. Ma femme s'inquiétait de plus en plus car elle en voulait un; elle avait vingt-six ans et elle se voyait vieillir; or chez nous, en Afrique, tu connais le prestige qui accompagne une femme-mère ou plutôt l'opprobre qui entoure une femme stérile. ${ }^{224}$

Kali á ainda um bom exemplo da impossibilidade de anulação dos vestígios de uma cultura. O homem que desprezava o mito da autenticidade e seus defensores se vê forçado a admitir o mistério de uma África que "surge, inesperada, como por refração, do lugar onde acreditamos tê-la enterrado com tanta eficiência" (DONGALA, 1982, P. 34):

J'ai tout de suite compris de quoi il s'agissait, car m'est immédiatement revenu en mémoire tout ce que je savais depuis ma jeunesse mais que j'avais toujours refoulé : il s'agissait de sorcellerie...

Kali rejeita a concepção animista da África em função da inadequação deste princípio com as suas conviç̧ões sociais e políticas, enquanto, Fama repudia a sociedade moderna por incompatibilidade com suas próprias aspirações. Os perfis são, de fato, distintos: Kali teve uma educação formal ocidental, enquanto Fama teve uma educação corânica, que proíbe qualquer prática animista, e sequer freqüentou a escola da administração colonial, mas ambos elegem seus campos de batalha em função de suas atividades e conviç̧ões políticas.

Além da frustração da esterilidade, Salimata e Fama dividem o recurso das analepses externas que resgatam o passado de ambos e instruem o leitor sobre as razões de seus destemperos presentes e sobre o grau de ligação de cada um à tradição. Na verdade, ambos recuperam, cada um a seu tempo e a

224 DONGALA, Emmanuel Boundzéki. L'étonnante et dialéctique déchéance du camarade Kali Tchikati. In: Jazz et vin de palme. Paris : Hatier, 1982. p. 16. 
seu modo, um passado anterior à vida que levam na capital. Salimata recupera com suas lembranças as experiências remotas que revelam dor da excisão, da violação e dos constrangimentos devidos ao fracasso de sua iniciação.

Segundo instruções recebidas de sua mãe, Salimata parte para o campo de excisão a fim de cumprir o rito de inserção na vida de mulher adulta:

Tu verras ma fille: pendant un mois tu vivras en recluse avec d'autres excisées et, au milieu des champs, on vous enseignera tous les tabous de la tribu. L'excision est la rupture, elle démarque, elle met fin aux années d'équivoque, d'impureté de jeune fille, et après elle vient la vie de femme. ${ }^{225}$

O ritual de ablação que deveria, em princípio, conduzir a jovem Salimata para uma experiência de júbilo, deixa apenas a lembrança traumática do sofrimento. Uma ruptura pós-excisão ocorre de fato, mas neste caso, trata-se de um rompimento em níveis mais profundos com o próprio fundamento do ritual: a excisão de Salimata não simboliza a passagem entre a experiência da vida livre de menina para o mundo das interdições que regulamentam a vida de mulher, mas a transição entre o significado dessa experiência para a mulher da sociedade tradicional africana e uma concepção que se aproxima da trajetória da mulher ocidental, para quem tal ritual representaria apenas violência e dor, e não teria nenhum aporte prático positivo em sua vida adulta.

O que deveria constituir uma manifestação significativa e válida para a identidade de Salimata, tornou-se uma experiência negativa que, pela demanda incessante da realidade, retorna em fluxos constantes, conduzindo à constatação quotidiana de uma deficiência ultrajante. Sob um disfarce a priori irreconhecível, as cores da excisão solicitam constantemente sua memória e a ascendência da experiência dolorosa:

Dans le sang et les douleurs de l'excision, elle a été mordue par le feu chauffé au rouge et du piment. Elle a crié, hurlé. Et ses yeux ont tourné, débordé et plongé dans le vert de la forêt ${ }^{226}$ puis le jaune de

225 KOUROUMA, LsdI, p. 34.

226 Grifos nossos. 


\section{I'harmattan et enfin le rouge, le rouge du sang, le rouge des sacrifices. ${ }^{227}$}

Do verde ao vermelho, ou da floresta aos sacrifícios, temos a indicação simbólica de um percurso que se inicia com elementos indiciais de vida e de fecundação e termina com a representação sígnica da morte: o verde da floresta viva sugere a reprodução fácil, sob condições adequadas, da vegetação; o amarelo do harmattan, a aridez de uma estação seca, improdutiva, estéril; e, por fim, o vermelho do sangue, da morte e do sacrifício. Consumidos pela dor, os olhos de Salimata perfazem e antecipam o desenrolar do caminho da mulher que parte do universo dos possíveis em direção à esterilidade, à frustração e à morte: a morte dos sonhos, mas também a morte funcional do ponto de vista social.

A visão sucessiva do verde, do amarelo e do vermelho precederia, a partir de então, outras experiências traumáticas de Salimata. Quando foi levada para a casa de Tiécoura, o feiticeiro que deveria cuidar de sua reabilitação após a excisão, Salimata foi violentada:

La case du fétiche était isolée, ronde, réduite, encombrée, grouillante de margouillats. (...) C'était là, au moment où le soleil commeçait à alourdir les paupières, que la natte s'écarta, quelque chose piétina ses hanches, quelque chose heurta la plaie et elle entendit et connut la douleur s'enfoncer et la brûler et ses yeux se voilèrent de couleurs qui voltigèrent et tournèrent en vert, en jaune, en rouge ${ }^{228}$, et elle poussa un cri de douleur et elle perdit connaissance dans le rouge du sang. Elle avait été violée. ${ }^{229}$

Na capital, a casa de Abdoulaye, marabu que deveria ajudar Salimata a livrar-se da esterilidade, lembra a atmosfera sufocante da casa de Tiécoura e a

\footnotetext{
${ }^{227}$ KOUROUMA, LsdI, p. 33.

228 Grifos nossos.

${ }^{229}$ KOUROUMA, LsdI, p. 39.
} 
alusão às cores do campo de excisão antecipa, de certo modo, a tentativa de mais uma agressão sexual ${ }^{230}$.

Dans la case, se chevauchaient des objets hétéroclites: marmites et calebasses d'abord, ensuite valises et nattes, près du lit des boubous jetés sur une corde et avec au-dessous les sortilèges rouges, jaunes et verts $^{231}$. Noir de fumée et trop bas était le toit de tôle. On étouffait. ${ }^{232}$

Dehors donnaient le vent et la pluie. Rien ne pouvait surprendre. Elle le fixa : pas de doute. Au cou montait les carcans de Tiécoura et le boubou prenait la couleur de l'habit de Tiécoura.

- Approche! Approche!

Il ne comprenait et n'entendait qu'une seule chose: lui et la femme étaient seuls. Il ne voyait qu'une femelle brillante, ronde, hésitante, mais soumise, et ne connaissant que le désir qui l'agitait et le chauffait. Il tira à arracher le pagne.

- Laisse-moi, ou je crie!

Il sourit. Non! Elle ne voudra pas crier; et il s'accrocha et tira plus fort ; la femme fut projetée, dispersée et ouverte sur le lit; il ne restait qu'à sauter dessus. Il ne le put ; [...] Dans les yeux de Salimata éclatèrent le viol, le sang et Tiécoura, et sa poitrine se gonfla de la colère de la vengeance. . $^{23}$

Em outros momentos, as cores apenas evocam a cena dolorosa, como a vertigem que sucede a morte do galo oferecido em sacrifício para exterminar a esterilidade:

Elle: l'essoufflement et les vertiges qui l'assourdissaient, l'étreignaient, et les couleurs qui se superposaient: le vert et le jaune dans des vapeurs rouges, le tout rouge ${ }^{234}$; la douleur et les roulements de ventre, les chants dans l'aurore; le champ de l'excision au pied des montagnes aux sommets vaporeux, le soleil sortant tout rouge, tout noyé dans le sang, le viol, la nuit et les lampes brillantes et éteintes et fumantes et les cris et les jambes piétinées, contusionnées, les oreilles meurtries, les pleurs et les cris et le pillage... ${ }^{235}$

${ }^{230}$ Quando Salimata procura Abdoulaye, ela havia sido roubada e agredida fisicamente no mercado. Além de querer resolver a questão da esterilidade, ela também pretende se livrar da má sorte de um destino desfavorável.

${ }^{231}$ Grifos nossos.

232 KOUROUMA, LsdI, p. 72.

233 KOUROUMA, LsdI, p. 76-77.

234 Grifos nossos.

235 KOUROUMA, LsdI, p. 74. 
Elementos do quotidiano de Salimata evocam, portanto, a lembrança traumática da excisão. Os exemplos acima citados mostram que, inconscientemente, Salimata encontrou nas cores verde, amarela e vermelha um sinal desfigurado que precede o ressurgimento do trauma. Mas tais fatos teriam, sem sombra de dúvida, uma outra explicação no âmbito da tradição, a exemplo do que ocorreu com a violação de Salimata:

Elle avait été violée. Par qui ? Un génie, avait-on dit après. On avait expliqué aussi les raisons. La maman de Salimata avait souffert de la stérilité et ne l'avait dépassée qu'en implorant le mont Tougbé dont le génie l'avait fécondée de Salimata. Salimata naquit belle, belle à emporter l'amour, à provoquer la jalousie du génie qui la hanta. On l'avait promise en mariage, on l'avait excisée sans avertir, sans calmer la passion du génie, par une adoration spéciale. C'était donc la jalousie et la colère du génie qui déclenchèrent l'hémorragie. C'était le génie sous la forme de quelque chose d'humain qui avait tenté de violer dans l'excision et dans le sang. ${ }^{236}$

No ambiente da capital, justificativas como esta seriam certamente relativizadas, a exemplo do que ocorreu com a gravidez psicológica de Salimata que durou dois anos sem aborto e sem parto:

Salimata s'en doutait et les sorciers le relevèrent, le confirmèrent: c'était le génie de fatalité qui la hantait au village, qui l'avait rejointe à la capitale. Il aimait Salimata, il ne la quittait jamais. Les effets de cette assiduité éclatèrent rapidement: le génie engrossa Salimata! Qu'importe qu'après que tout fût tombé, se fût envolé, le docteur ait appelé cet état "une grossesse nerveuse" et les Malinkés "une grossesse de génie" ! !37

Salimata tem, portanto, um percurso no qual os influxos da modernidade não constituem uma ruptura propriamente dita em seu modo de vida. No seu caso, a divisão se opera em meio a uma visão de mundo tradicional, sem nenhuma interferência da vida moderna. Aliás, seja por vingança do gênio que não foi devidamente celebrado durante a excisão, seja por um "pressentimento" da chegada de novos tempos, o fato é que Salimata

${ }^{236}$ KOUROUMA, LsdI, p. 38-39.

237 KOUROUMA, LsdI, p. 52. 
rejeita, de certa forma, a tradição no momento em que duvida da eficácia e do sentido da excisão:

Mais quelle grande signification? ${ }^{238}$

Depois de sua recuperação na casa de Tiécoura, Salimata foi dada em casamento a Baffi, um homem que the causava profunda aversão; o casamento não se consuma devido ao trauma de Salimata, que acaba estrangulando a hérnia do marido, levando-o à morte:

... elle appartenait au diable, elle demeurait toujours hantée par le génie, le même génie qui l'avait violée; il s'opposait à tout rapport de Salimata avec les hommes, d'où les cris, les horreurs les actes criminels (coup de main dans la hernie). ${ }^{239}$

Meses depois de ter se recuperado da viuvez, segundo os hábitos tradicionais de reclusão, Salimata é entregue ao irmão de Baffi, a quem deve servir como esposa a partir de então. Horrorizada com a semelhança de Tiémoko com Baffi, que, por sua vez também lembrava o feiticeiro Tiécoura que a violou após a excisão, Salimata foge após ter sido seqüestrada e ameaçada por Tiémoko. A recusa de Salimata em permanecer no ambiente de seu vilarejo natal revela, de certo modo, uma inadaptação à tradição, mas, na verdade, a tradição já havia rejeitado Salimata desde o campo de excisão. Não tendo sido bem sucedida, Salimata não representou o orgulho de sua mãe ou de sua tribo; além disso, não foi oferecida em sacrifício aos ancestrais como as demais meninas que não resistiram ao rito de iniciação, e cujos corpos permaneceram na floresta em oferenda, fazendo o orgulho dos pais que tiveram suas filhas escolhidas para serem levadas em sacrifício para felicidade do vilarejo (KOUROUMA, LsdI, p. 36). Salimata não significou nenhum acréscimo importante para a comunidade e, por isso, foi associada a um espírito assombrado pelo gênio ou presa do diabo.

238 KOUROUMA, LsdI, p. 34.

239 KOUROUMA, LsdI, p. 41-42. 
Salimata como uma boa africana mantém a submissão; mas não se trata apenas da submissão ao marido e resposta às exigências feitas à mulher, mas da submissão às circunstâncias. Vivendo na capital, ela se adapta às horas da fábrica onde exerce sua atividade remunerada para atender às necessidades de seus compromissos. Salimata obedece, portanto, o ritmo da capital na medida em que essa nova marcação temporal não entra em conflito com os princípios da tradição aos quais está habituada. Se Salimata pode ser considerada o duplo de Fama, tal análise só pode ser comprovada pela abstração das atribuições de gênero e extensão às capacidades humanas de adaptação. Em oposição ao que ocorre com Fama, Salimata assume o novo contexto social, mas tal integração deve levar em conta o fato de que, para a mulher, as transformações de ordem social e política são fatos externos às suas atividades.

Em oposição à Salimata, surge Mariam, a segunda esposa que the foi deixada como herança pelo falecido primo no Togobala. Antes de tornar-se uma das esposas de Lacina, Mariam já havia sido prometida a Fama porque todos protestavam de le voir se consumer dans une stérilité aride avec Salimata (KOUROUMA, LsdI, p. 90). Mas, o casamento não se realiza por duas razões:

D'abord à cause des sarcarmes de Salimata. «Fama, Fama, disait-elle, réfléchis, regarde-toi. Te sens-tu capable d'en chevaucher deux ? Avec moi, c'est aussi difficile que tirer l'eau d'une montagne. Et après chaque nuit les douleurs qui circulent dans les reims et les côtes... » Ensuite parce que c'était l'époque où les affaires périclitaient, où la politique l'accaparait. Bref, Fama avait refusé Mariam parce qu'il n'avait ni reins ni l'argent. Au village, on avait juré, protesté, médit de Fama : un légitime, un fils de chef qui courbait la tête sous les ailes d'une femme stérile, un dévoyé ! ${ }^{240}$

Com a morte de Lacina, Mariam fazia parte da herança de Fama que, depois de certa hesitação ${ }^{241}$, decidiu levá-la à capital. A boa acolhida de

\footnotetext{
240 KOUROUMA, LsdI, p. 90-91.

${ }^{241}$ Près de vingt ans de vie commune avaient amené Fama et Salimata à se connaître comme la petite carpe et le crocodile cohabitant dans le même bief. Que Fama marie
} 
Salimata à segunda esposa de Fama não tardaria a revelar a dissimulação e a provocar as inevitáveis crises entre as co-esposas. Uma situação bastante comum no universo da África poligâmica ${ }^{242}$.

Salimata se sente perturbada pelas noites que pertencem a Mariam e pela possibilidade de que Mariam possa ter o filho que ela, Salimata, jamais teria (KOUROUMA, LsdI, p. 78). O afrontamento se torna inevitável e a disputa revela a imagem de perfis femininos bastantes distintos:

A chaque réveil, Salimata regardait le ventre de la coépouse, et le ventre semblait pousser. Oui, il poussait! Salimata devint jalouse, puis folle et un matin elle explosa, injuria. Les deux coépouses comme deux poules s'assaillirent, s'agrippèrent l'une au pagne de l'autre. Mariam voulait coûte que coûte tomber le pagne de Salimata afin que chacun vit "la matrice ratatinée d'une stérile" et Salimata dévêtir Mariam afin que tout le monde reconnût "la chose pourrie et incommensurable d'une putain". ${ }^{243}$

$\mathrm{Na}$ análise referente à vida privada de Fama, Borgomano considera a altercação entre as esposas como uma percepção externa da vida interior de ambas e que, além disso, o romance não atribuirá, em momento algum, uma

Mariam après les funérailles et retourne dans la capitale, il était aisé d'imaginer ce que ferait Salimata : hypocrite, le premier jour elle se vêtira d'une fausse gentillesse avec des sourires à se fendre, s'emmanchera de faux empressements et de prévenances. «Une femme sans limite », pourrait-on penser. Non! Attendez! Un soir, sans aucune raison, elle arrivera silencieuse, comme traversée et cassée par des soucis de foudre. Et ça commencera. Retirée dans un coin, elle bramera des chants avec des paroles philosophant sur la misère humaine, sur la misère des épouses qui nourrissent, vêtent et logent leur mari, sur la misère des épouses devant l'ingratitude des hommes, sur les devoirs des maris, sur la stérilité, sur l'obligation de loger chaque coépouse dans sa chambre, et puis... et puis... bref, des lancées de mauvaise humeur qui finiront par agacer et piquer Fama. (KOUROUMA, LsdI, p. 92-93).

242 No estudo de Camara Sory sobre o conto "Le Berger", o autor faz o seguinte comentário: Quem conhece a vida doméstica mandenka, marcada por rivalidades e animosidades provocadas pela poliginia, pode facilmente imaginar a hostilidade e, às vezes, o ódio que opõem as mulheres e que elas projetam sobre os filhos de suas coesposas; desconfia-se de feitiçaria perversa, de envenenamentos, etc., provenientes de ambas as partes. [Qui connaît la vie domestique mandenka, marquée par les rivalités et les animosités provoquées par la polygynie, imagine aisément l'hostilité et parfois la haine qui opposent les femmes et qu'elles projettent sur les enfants de leurs coépouses; on se soupçonne mutuellement de sorcellerie malveillante, d'empoisonnements, etc.] (CAMARA, 1982, op. cit., p. 192).

${ }^{243}$ KOUROUMA, LsdI, p. 152. 
vida interior à frívola Mariam ${ }^{244}$. Comparada a Salimata, a narrativa enfoca Mariam como uma mulher dos costumes ligeiros; mesmo durante os funerais de Lacina, ela exibe um luto não muito convincente e deixa escapar, aos olhos de Fama, um certo jogo de sedução:

... elle lui avait semblé s'être parée du deuil comme une courtisée se pare d'un collier d'or un jour de danse. On pouvait jurer sur Allah, elle jouait la pleureuse, s'amusait à la lamentée. [...] Les cheveux non tressés comme le veut la coutume, en broussaille comme chez une folle, apportaient beaucoup de malignité à ses yeux brillants de lièvre. Le visage luisait, la poitrine aussi, et les seins serrés dans le pagne indigo rebondissaient, ramassés et durs comme chez une petite jeune fille. Les cuisses et les fesses se répandaient, infinies et ondulantes sous le pagne. Quel saisissement au toucher! $!^{245}$

A bela mulher, ligeira, sarcástica e sem vínculos aparentes, fará a passagem do espaço fechado da tradição ao espaço dinâmico da capital sem muitos prejuízos pessoais. Ao contrário, a vida na capital abre para Mariam a possibilidade de dar pleno curso a esse aspecto superficial de sua personalidade. Aliás, ambas, Salimata e Mariam decidem seguir novos rumos após a prisão de Fama, mas enquanto o novo vínculo de Salimata com Abdoulaye parece remontar a um sentido de "cura" para a mulher que não engravidava em função de seu trauma e só sabia deitar-se com um homem estéril, com Mariam a união com o chofer de táxi que os levou para a casa de Fama quando chegaram à capital representa, antes, o encontro de dois seres pouco afeitos a questões de ordem tradicional. Quando Fama deixou a prisão, seu amigo Bakary revelou o que havia se passado com suas duas esposas. No caso de Mariam, Bakary tentou intervir por reconhecer em sua relação com Papillon um envolvimento de alguém que não possui grande discernimento:

244 ... le roman n'accordera jamais aucune vie intérieure à la frivole Mariam. (BORGOMANO, 1998, op. cit., p. 98).

${ }^{245}$ KOUROUMA, LsdI, p. 128-129. 
Il papillonnait nuit et jour au portail, faisait ronfler le moteur et klaxonnait. Mariam sortait. Avec Papillon elle allait se promener et ne se rassasiait jamais de partir en voiture. ${ }^{246}$

Aussi Bakary avait saisi Papillon au collet (...) «Tout le monde voit que tu détournes Mariam. N'as-tu pas honte, Papillon, de t'amuser avec les choses de vieux ? (...) le mari de Mariam s'appelle Doumbouya, c'est un vrai prince. (...) Il n'est pas un homme de l'indépendance et jamais il ne te pardonnera d'avoir entré la lame de ton couteau dans la gaine de son sabre. (...) Mariam est ensorcellée (...) tôt ou tard, ton pênis va disparaître... » (...) Papillon n'avait pas bronché (...) en s'asseyant dans sa voiture il avait haussé les épaules. ${ }^{247}$

Embora Papillon tenha uma participação que não representa grande interesse para a progressão dramática do texto, sua existência na trama tornase relevante na medida em que subscreve nossa hipótese: a hipótese de que o romance apontaria para uma configuração da era moderna que Bauman interpreta como a era da fluidez e dos contatos breves; enfim, o que nomeamos aqui como laços efêmeros, que se inscreveriam na obra como uma configuração não programada do autor, mas que apontam para uma aceleração do processo de modernidade devido aos influxos ocidentais. Papillon ouve o discurso de Bakary sem vacilar e sem reagir, numa atitude de profundo desdém pela tradição; ele entra em seu carro, símbolo inconteste da modernidade e do avanço no espaço e no tempo, e segue seu caminho dando de ombros, numa atitude típica de quem não tem tempo a perder com coisas que não fazem sentido.

\section{Do espaço organizado à geografia da exclusão}

No segundo capítulo do livro Edouard Glissant: Poética e Política, Diva Damato (1995) analisa a organização do espaço das Antilhas francesas a partir do massacre da população indígena e do repovoamento das ilhas com o tráfico

\footnotetext{
246 KOUROUMA, LsdI, p. 177.

247 KOUROUMA, LsdI, p. 177-178.
} 
negreiro, examinando as conseqüências materiais, culturais e psíquicas causadas pelo problema da depossessão do espaço. Na transposição dos homens que chegam como trabalhadores e escravos fica para trás o espaço ancestral, no qual os mitos que recordam um estado primordial expressam, em planos diversos, e com os meios que lhe são apropriados, um complexo sistema de afirmações coerentes sobre a realidade final das coisas (ELIADE, 1992 , p. 17). Esses homens chegam despojados de todo e qualquer elemento que, no quotidiano, garantiam, até então, seu equilíbrio material e espiritual. Se o africano chega em terras americanas como o "migrante nu" (DAMATO, 1995, p. 152), aquele que permanece e tem seu espaço invadido pelo estrangeiro possui, ao menos, a âncora material do solo:

Os povos que sofreram invasões, por mais violentas que tenham sido, na medida em que permaneciam em seu território, tinham alguma condição de resistir. A presença do inimigo, modificando suas leis, ou violentando seus costumes, não era suficiente para destruir o continuum em que estavam inseridos. O conhecimento da terra permite-lhes preservar alguns hábitos que os mantém como povo: a cultura de um povo está intimamente ligada à sua paisagem ${ }^{248}$.

Mas se, por um lado, a permanência em seu próprio território garante a sobrevivência desse continuum da história local, por outro, ela não impede a ação de um fenômeno também comum aos africanos da diáspora: a debilitação e descredenciamento dos valores e recursos de manutenção social e cultural de um povo. O que se pode constatar na apreciação do quadro das grandes mudanças históricas promovidas pela Europa em suas conquistas coloniais é que, a despeito da pretensão do ocidente ao universal, essas alterações não impediram a passagem do universo transcendental do Mesmo (...) ao conjunto difratado do Diverso, conquistado de modo não menos fecundo pelos povos que, hoje, conquistaram seu direito à presença no mundo ${ }^{249}$. Se nos dias

248 DAMATO, Diva. Edouard Glissant: poética e política. Prefácio: Edouard Glissant. São Paulo: Annablume: FFLCH, 1995, p. 148. Os grifos são da autora.

249 ... de l'univers transcendantal du Même (...) à l'ensemble diffracté du Divers, conquis de manière non moins féconde par les peuples qui ont arraché aujourd'hui leur 
atuais, passados mais de quarenta anos da independência dos países do oeste africano, a África ainda discute questões referentes à nacionalidade e cidadania, tal fato mostra a resistência de princípios étnicos às interferências estrangeiras. Na observação de Elikia M'Bokolo:

Sabe-se que, nas classes populares e, em particular, nas zonas rurais, a realidade material e jurídica das fronteiras, todas de origem colonial, ainda não se tornou uma realidade política, e muito menos afetiva ou psicológica. Ao contrário, o estudo da dinâmica social e cultural dos últimos trinta anos confirma, no interior do continente, a progressão dos fenômenos trans-fronteiriços e transnacionais, em áreas tão variadas quanto as línguas, os modos, as crenças e as práticas religiosas. ${ }^{250}$

Como vimos no capítulo "Dinâmica das identidades", Zygmunt Bauman associa a questão espacial ao lado sólido e impassível da tradição, enquanto o tempo representa o lado dinâmico da força invasora. No caso da África de colonização francesa, o comando à distância já começa a despontar quando o colonizador intelectualiza os poderes locais tradicionais, substituindo os chefes hereditários, analfabetos, por intelectuais e universitários, e delegando poder a um procurador local. Com isso, as operações de comando passaram a ser realizadas à partir dos centros urbanos e o espaço físico deixou de constituir um empecilho para a força colonizadora.

Em literatura, a imagem do indivíduo é determinada pelo cronotopo conteudístico-formal, onde os índices do tempo transparecem no espaço, e o espaço reveste-se de sentido e é medido com o tempo (BAKHTIN, 1993, p. 211). Como o referente histórico guiou seus pólos centrais de execução, ou

droit à la présence au monde. (GLISSANT, Édouard. Poétique de la relation. In: Le discours antillais. Paris: Gallimard, 1997b, p. 326).

250 On sait que, dans les classes populaires et en particulier dans les zones rurales, la réalité matérielle et juridique des frontières, toutes d'origine coloniale, n'est pas encore devenue une réalité politique, encore moins affective ou psychologique. Au contraire, l'étude de la dynamique sociale et culturelle des trente dernières années confirme, à l'intérieur du continent, la progression des phénomènes transfrontaliers et transnationaux, dans des domaines aussi variés que les langues, les modes, les croyances et les pratiques religieuses. (M'BOKOLO, Elikia. L'ère des indépendances. In: NOTRE LIBRAIRIE : Revue du livre: Afrique, Caraïbes, Océan Indien. Écrivains de langue française : Afrique noire, Maghreb, Caraïbes, Océan Indien. Paris : Clef, n. 108, jan.-mars 1992, p. 22). 
seja, o "realismo" e a "verdade", o espaço da ficção africana não poderia deixar de refletir, e denunciar, a operação de quebra na estrutura sócioeconômica e cultural da tradição, que rompeu com o passado e estabeleceu nos espaços urbanos a imagem da segregação ideológica do novo poder. Desde sua organização mais elementar, a separação entre negros e brancos já era visível na organização do espaço urbano: bairro administrativo e casernas militares, entrepostos de comércio e locais do mercado, bairro "autóctone" dos auxiliares da colonização e zona suburbana que abrigava os primeiros marginais do sistema... ${ }^{251}$

Em Kuma - interrogation sur la littérature nègre de langue française, Makhily Gassama (1978, p. 271) analisa a oposição existente entre cidades e vilarejos sob a perspectiva da escrupulosa obediência do romancista africano à verdade da observação. Visando enfocar a exploração do espírito supersticioso como recurso dramático nos romances africanos de língua francesa, o autor aborda a questão da transposição espacial do meio rural para os centros urbanos e a extensão dos hábitos e costumes tradicionais. Como um dos pontos importantes dos textos analisados por Gassama, ressaltamos o comentário do narrador de Ville cruelle (1954), de Eza Boto ${ }^{252}$. Mesmo consciente da existência de "dois mundos" na cidade de Tanga, onde os bairros da administração e do comércio se opõem ao bairro autóctone que se assemelha ao village de brousse, constata que: Tout va très vite aujourd'hui en Afrique!, mostrando que a aceleração do ritmo como motor das mudanças no período colonial, já se fazia sentir nos romances do período colonial.

Em Les soleils des Indépendances, a distribuição espacial se organiza em torno de três pólos principais : o espaço urbano da capital, o meio rural do village e o espaço carcerário, no qual a suspensão temporal inscreve a

251 ... quartier administratif et casernements militaires, entrepôts de commerce et abords du marché, quartier «indigène » des auxiliaires de la colonisation, et zone suburbaine montante des premiers marginaux du système... [COQUERY-VIDROVITCH, Catherine. In : KIPRÉ, Pierre. Villes de Côte d'Ivoire: 1893-1940 : Fondation des villes coloniales. Préface : Catherine Coquery-Vidrovitch. Abidjan - Dakar - Lomé: NEA, 1985a. Tome I. p. 3.

252 Pseudônimo de Mongo Beti. 
representação da morte. A capital descrita pelo narrador é sem dúvida a cidade de Abidjan, com seus dois bairros nitidamente separados pela lagoa atravessada por Salimata quando, ao meio-dia, corre para o mercado, situado no plateau ${ }^{253}$, a fim de obter os recursos que sustentam o marido e os sortilégios e sacrifícios necessários à fertilidade. Ao rigor dos compromissos e às idas e vindas de Salimata no espaço da capital se opõem os trajetos de Fama, que distribui seu tempo entre o bairro africano, onde leva uma existência ociosa às expensas da esposas, e o bairro dos funcionários administrativos ao qual se dirige pelo compromisso com os funerais malinkés. A morte do malinké da casta dos ferreiros, Ibrahima Koné, tem especial interesse dramático na medida em que acentua a debilidade funcional de Fama; sua presença não só é dispensável como também é ironizada em razão de sua pretensão ao reconhecimento da honorabilidade do príncipe do Horodougou. À parte sua corrida de funeral em funeral, Fama se dedica às preces quotidianas na mesquita, numa insistente solicitação a Alá: a primeira parte, recitada na língua abençoada de Alá, o árabe, suplica o conforto do paraíso; a segunda, por seu caráter material, é recitada em malinké, na qual implora:

... sa reconnaissance pour la subsistance, la santé, pour l'éloignement des malchances et malédictions noircissant le nègre sous les soleils des Indépendances, prier pour chasser de l'esprit et du coeur les soucis et tentations et les remplir de la paix aujourd'hui, demain et toujours. ${ }^{254}$

As maldições que cobrem os negros se refletem na distribuição do espaço urbano e no modo como Fama se relaciona com a capital:

L'orage était proche! Ville sale et gluante de pluies! pourrie de pluies! Ah ! nostalgie de la terre natale de Fama! Son ciel profond et lointain, son sol aride mais solide, les jours toujours secs. ${ }^{255}$

253 Os nomes correspondem às vezes a lugares do mundo real, como no caso do "plateau": conhecido centro de comércio e negócios de Abidjan.

${ }^{254}$ KOUROUMA, LsdI, p. 27.

255 KOUROUMA, idem, p. 27. 
Na descrição da cidade suja, grudenta de chuva e podre, os adjetivos denotam a degradação que, na percepção de Fama, corresponde à própria degeneração do negro da capital. Justapostos, os termos suja, grudenta e podre demonstram uma ação crescente de deterioração sem remédio: da sujeira à viscosidade têm-se a imagem da substância que, pela natureza de sua consistência, retém o sujeito preso ao local da miséria. As chuvas que caem sobre a cidade é o extremo oposto da chuva benéfica e necessária como aquela que irriga o solo e propicia a boa colheita; trata-se das chuvas insalubres que, caídas sobre o lixo e sem escoamento adequado, geram a matéria em decomposição, fétida e infecta das ruas sem esgoto (KOUROUMA, LsdI, p. 27). Essa visão de Fama seria, portanto, um exemplo da lenta evolução dos modernos centros urbanos africanos no que se refere às obras de urbanização. No caso específico da Costa do Marfim, o programa de urbanismo colonial só atendeu a um número restrito de centros e foi uma implantação tardia e mal conduzida. No próprio interior dessas aglomerações, apenas a 'cidade européia' se torna objeto de uma atenção especial. ${ }^{256}$

Os elementos da natureza - o sol, o céu, a chuva, a vegetação - são abordados segundo uma consciência intencional que os dirige ora para a ação positiva, ora para o malefício. Trata-se de uma alternância constante do campo semântico desses elementos cuja variação depende do enfoque pretendido. $\mathrm{Na}$ cidade, a natureza ganha um aspecto que acompanha o desafeto do personagem na sua relação com o espaço que representa sua desqualificação; no Horodougou, os elementos da natureza participam das ações quotidianas e regem os movimentos e ações dos indivíduos.

256 ... un programme qui ne touche qu'un nombre restreint de centres (...) tardif et mal conduit. A l'intérieur même des agglomérations, seule «la ville européenne » fait l'objet d'une attention particulière. (KIPRÉ, Pierre. Villes de Côte d'Ivoire: 18931940. Économie et sociéte urbaine. Abidjan - Dakar - Lomé: NEA, 1985b. Tome II. p. 16). 
Como Fama não possui nenhuma ligação com a modernidade instaurada pela colonização, tudo aquilo que o aflige conduz naturalmente à nostalgia dos tempos passados, de modo a balayer l'outrage e noyer la colère:

Oh! Horodougou! tu manquais à cette ville et tout ce qui avait permis à Fama de vivre une enfance heureuse de prince manquait aussi (le soleil, I'honneur et l'or), quand au lever les esclaves palefreniers présentaient le cheval rétif pour la cavalgade matinale, quand à la deuxième prière les griots et les griottes chantaient la pérénité et la puissance des Doumbouya, et qu'après, les marabouts récitaient et enseignaient le Coran, la pitié et l'aumône. 257

Mas a nostalgia de Fama não chega a suscitar a simpatia do leitor, pois ao lado de sua revolta contra a era das independências, o personagem revela o perfil do sujeito voltado apenas para os interesses pessoais. No caminho em direção à mesquita, onde faz suas preces quotidianas, Fama, banindo, à sua conveniência, os preceitos do alcorão de piedade e misericórdia, não esconde a repulsa pela pobreza dos excluídos:

Les bas-côtés grouillaient de mendiants, estropiés, aveugles que la famine avaient chassés de la brousse. Des mains tremblantes se tendaient mais les chants nasillards, les moignons, les yeux puants, les oreilles et nez coupés, sans parler des odeurs particulières, refroidissaient le coeur de Fama. Il les écarta comme on fraie son chemin dans la brousse, sauta les tronçons et pénétra dans la mosquée, tout envahie par la grandeur divine. ${ }^{258}$

A constatação da existência dos excluídos do espaço urbano não altera em nada o rumo dos questionamentos íntimos de Fama. Considerando-se os principais traços de caráter do personagem, somos inclinados a concordar com a afirmação de Gassama de que Ahmadou Kourouma, tanto quanto Ferdinand Oyono, apresenta ao leitor um mundo desprezível: eles detestam seus personagens que são perseguidos sem piedade. Aliás, trata-se de personagens

${ }^{257}$ KOUROUMA, LsdI, p. 21.

258 KOUROUMA, LsdI, p. 26. 
pouco gentis porque são corrompidos pelos meios nos quais evoluem: meios artificiais nascidos da situação colonial! $!^{259}$

A predisposição de Fama à corrupção fica evidente em algumas passagens pontuais do romance: quando afirma que teria feito qualquer coisa para ser agregado ao sistema político das Independências (KOUROUMA, LsdI, p. 25); e em sua passagem pelo mercado, quando os odores o fazem lembrar todos os grandes centros que ele havia freqüentado em seus tempos de comerciante, trazendo a certeza de que, se lhe fosse dado optar, teria preferido a manutenção do domínio colonial a fim de continuar exercendo sua função no comércio e manter, ao menos, uma das atribuições de um verdadeiro malinké. Segundo Fama, a colonização havia acabado com a guerra, mas favorecido o comércio, enquanto que as Independências acabaram com o comércio e não trouxeram de volta a guerra, exterminado assim os fundamentos da identidade malinké:

... l'espèce malinké, les tribus, la terre, la civilisation se meurent, percluses, sourdes et aveugles... et stériles. ${ }^{260}$

A concepção da capital como uma geografia da exclusão serve para ratificar os principais traços da psicologia de Fama: o espaço desorganizado da capital e a ênfase nos aspectos perversos da cidade corroboram com a reação do personagem a um mundo às avessas, que perdeu seu norte no momento em que a estrutura espaço-temporal da tradição foi substituída pela organização "profana" da modernidade. Uma vez perdidas as referências básicas de organização do mundo tradicional, Fama se debruça sobre a luta contra os bastardos que o destronaram, contra os bastardos compatriotas, que reproduzem a conduta do homem branco, e contra as Independências, que the despojaram da identidade autêntica, deixando-Ihe apenas a carteira de

259 ... ils détestent leurs personnages qu'ils traquent sans pitié. Du reste ce sont des personnages peu aimables puisque dénaturés par les milieux dans lesquels ils évoluent : milieux artificiels que ces milieux nés de la situation coloniale! (GASSAMA, Makhily, op. cit., 1978, p. 315).

${ }^{260}$ KOUROUMA, LsdI, p. 23. 
identidade e do partido único como meios de identificação. Não sendo um espírito intelectualmente apurado, o personagem principal de Les soleils des Indépendances declara suas perdas e reivindica um reconhecimento social baseando-se no discurso recorrente e pouco organizado da enumeração das perdas. Fato é que Kourouma, em seu propósito de mostrar aos europeus o que eles haviam feito ao continente africano, levanta também uma questão da debilidade de um personagem da tradição que deveria, em princípio, comandar. Suas duas passagens pelas fronteiras ${ }^{261}$ que separam a Costa dos Ébanos da República do Nikinai mostram a reação de um indivíduo obnubilado pela ira e que não apresenta nada em comum com outros personagens articulados das literaturas africanas, cuja coerência e profundidade do discurso nem sempre é devida à educação formal (ocidental), mas à sabedoria como legado da educação africana, a educação da etnia, [exercida] junto aos pais e que só pode ser feita por meio da experiência. ${ }^{262}$ No romance La carte d'identité, por exemplo, de Jean-Marie Adiaffi, a perda deste documento introduzido pelos colonizadores oferece a oportunidade, para o leitor, de entrar em contato com uma profunda reflexão de Mélédouman, o personagem principal, a respeito desse símbolo da colonização e da negação ao direito à diversidade. Um exemplo de sagacidade pode ser encontrado em sua bela argumentação contra a proibição de falar os dialetos locais nas escolas:

Mais, vois-tu, une langue est un organisme vivant, un être qui a un esprit et une âme comme nous. Et comme tout ce qui est vivant, elle naît, respire, se nourrit, grandit se reproduit éventuellement, vieillit et meurt. Comme tout ce qui est vivant, elle est souple et s'adapte aux nouvelles conditions. D'abord nos langues sont aussi belles que les autres. Elles ont fait leurs preuves en permettant la production de cette belle littérature, de cette profonde philosophie, que sont la littérature et la philosophie de la grande civilisation ashanti ; et plus loin de nous les civilisations du Manding, du Congo, du Bénin. [...] Je ne dis pas de faire

\footnotetext{
${ }^{261}$ A primeira, quando vai ao Togobala para os funerais do primo Lacina e a segunda, quando retorna, ao final do romance, para morrer no Horodougou. A passagem pela fronteira no retorno à capital, após os funerais, não é mencionada.

262 NOKAN, Charles. Charles Nokan: Depoimento [mar. 2006]. Entrevistadora: Maria Suzana Moreira do Carmo. Abidjan, 2006. 1 fita cassete (60 min). Cf. Anexo I desta pesquisa.
} 
comme si les Blancs n'étaient pas venus. Je dis que si nous abandonons tout, soit par faiblesse, soit par négligence, soit par étourderie, par distraction, personne ne pourra, venu le tribunal de l'histoire, évaluer la perte monumentale ainsi subie. ${ }^{263}$

Empobrecido em suas argumentações, Fama não consegue ir além da compulsiva comparação entre a mestiçagem da cultura malinké com a cultura ocidental e a corrupção biológica concentrada na bastardia e seus derivados. Em "La bâtardise"264, Harris Memel-Fotê analisa o conteúdo desse termo do ponto de vista jurídico e suas implicações ideológicas no emprego abundante e obsessivo que Fama faz da expressão. O bastardo, na expressão da consciência política dominante, é o indivíduo desprovido dos direitos sociais fundamentais e sua situação de excluído reproduz 0 ato de invalidade social. No conteúdo global do romance de Kourouma, tal noção denota a concepção de corrupção que, para Fama, se estabelece em vários níveis: a corrupção da natureza, da desordem social e da cultura malinké. Assim, é sob essa perspectiva de degeneração que Fama concebe a oposição entre o bairro dos negros e o bairro dos brancos:

Damnation de bâtardise! Le nègre est damnation! les immeubles, les ponts, les routes de là-bas, tous bâtis par des doigts nègres, étaient habités et appartenaient à des Toubabs. Les Indépendances n'y pouvaient rien ! 265

Associada à degradação do espaço, a natureza também desempenha um papel importante na oposição entre cidade "branca" e cidade "negra", tornando-se um suporte privilegiado de significações. No primeiro capítulo, já podemos suspeitar que o uso da palavra "sol" remonta a um duplo sentido. Se no romance ele adquire o sentido inusitado de "era", de "período" ${ }^{266}$, despojando-se de seu sentido astrológico e tornando-se imagem simbólica (KOTCHY, 1977), ele não deixa de reforçar o tema da narrativa:

${ }^{263}$ ADIAFFI, Jean-Marie. La carte d'identité. Abidjan: CEDA, 1980. p. 106-108.

264 In: Actes du séminaire sur Les soleils des indépendances. Université d'Abidjan: NEA, 1974.

265 KOUROUMA, LsdI, p. 20.

${ }^{266}$ Kourouma explica o sentido da palavra sol para os malinkés. 
Le soleil! Le soleil! Le soleil des Indépendances maléfique remplissait tout un côté du ciel, grillait, assoiffait l'univers pour justifier les malsains orages des fins d'après-midi. ${ }^{267}$

Se o uso malinké é aqui evidente, a construção sintagmática e a referência às insalubres tempestades também permitem uma imediata associação ao astro que contém em si a vida e a morte, anunciando a presença de mais um elemento de comparação que reforça o sistema binário de reflexão de Fama:

Tout porte à la fois la mort et la vie. La pluie tombe la foudre et l'eau nourricière, la terre sort la moisson et retient les restes dans la mort, le soleil diffuse la clarté et la sécheresse; les années déroulent l'âge et les famines, les enfants et les Indépendances. ${ }^{268}$

Despojado de sua natureza vivificadora, de seus atributos de luminosidade, de calor e de vida, esse sol que abre o romance rompe a medida justa e queima onde deveria fazer germinar, sufoca e amedronta onde deveria tranqüilizar. O sol surge, portanto, sob o signo da metalinguagem: uma imagem consoante à imensidão do fracasso e da vergonha de Fama, o príncipe moralmente atingido e condenado à desonra. A recusa do belo emerge então como resposta imediata, quase epidérmica, aos insultos e humilhações sofridas.

A imagem que se desprende da presença do sol na capital não é a mesma da que será esboçada sob o céu de Togobala. Este, como sinônimo de alegria e felicidade, se opõe e sobrepuja o primeiro, que se mostra impregnado pelo desprezo e pela indiferença de Fama com relação a tudo que evoca as Independências, o partido único e, enfim, tudo o que se refere à sua ruína.

Na verdade, a cisão é nítida, pois mesmo no período que antecede as independências, o sol da colonização já havia estabelecido tal divisão,

\footnotetext{
267 KOUROUMA, LsdI, p. 11.

268 KOUROUMA, LsdI, p. 117.
} 
deixando a cada um aquilo que the era supostamente devido: ao branco, as habitações iluminadas e aos negros, a danação dos buracos soturnos:

... et le soleil, déjà harcelé par les bouts de nuages de l'ouest, avait cessé de briller sur le quartier nègre pour se concentrer sur les blancs immeubles de la ville blanche. ${ }^{269}$

A imagem do sol que precede as tempestades é, portanto, a que abandona, em primeiro lugar, o bairro negro e se concentra para iluminar com mais empenho as casas dos brancos; estes, aliás, nunca são expostos às trevas, pois à noite, as lâmpadas elétricas iluminam a capital. Remontando a uma lógica maniqueísta do romance, tal divisão constitui o avatar da derrota de Fama, tal qual o havia previsto a voz noturna a Bakary, logo após a conquista do Horodougou pelos Malinkés muçulmanos do norte:

La fin de ta descendance n'arrivera ni demain, ni après-demain, ni un jour prochain. Il se fera un jour où le soleil ne se couchera pas, où des fils d'esclaves, des bâtards lieront toutes les provinces avec des fils, des bandes et du vent, et commanderont, où tout sera pleutre, éhonté, où les familles seront... ${ }^{270}$

Quando Fama afirma que o sol brilha para os brancos na capital da Costa dos Ébanos, não se pode deixar de inferir o sentido de usurpação subliminar a seu discurso: para ele, não há benefício usufruído pelo homem branco em seu país que não seja fruto de apropriação indébita.

É a partir do momento em que o príncipe empreende a viagem ao Togobala que os atributos do sol são gradualmente atenuados até que ele possa reencontrar um sol familiar, o sol de sua infância:

De partout sirgissaient des bruits, des odeurs et des ombres oubliés, même un soleil familier sortit et remplit la brousse. Son enfance! $!^{271}$

\footnotetext{
269 KOUROUMA, LsdI, p. 20.

270 KOUROUMA, LsdI, p. 99.

${ }^{271}$ KOUROUMA, LsdI, p. 102.
} 
Desse modo, a segunda parte do romance se opõe à primeira tanto no plano da ação quanto no plano da organização espacial, de modo que o universo urbano da capital dá lugar ao mundo da savana, da floresta, do village e esses dois universos se manifestam de modos totalmente distintos, ou mesmo opostos. ${ }^{272}$

A viagem ao Togobala de sua infância é empreendida como uma obrigação que dissimula, no fundo, um desejo intenso de Fama de reconquistar seu antigo poder e suas riquezas morais, espirituais e materiais. Com a morte de seu primo Lacina, o comando do Togobala e de todo o Horodougou caberia, em princípio, a Fama, mas a realidade do estado do village só poderá ser realmente medida após a grande viagem de reconhecimento. Como vimos em "A viagem imaginada e o deslocamento efetivo", dentro da concepção tradicional, a viagem podia tomar a forma de dois tipos distintos de deslocamento: a locomoção efetiva do herói épico que sai em busca da restauração da própria honra e da restituição dos direitos usurpados ou a viagem iniciática, que não implica necessariamente uma alteração do espaço físico e pode tomar a forma de um movimento interior na busca do amadurecimento. A viagem de Fama para funerais de Lacina pode, de certo modo, ser entendida como essa longa trajetória do indivíduo que, ao final de sua jornada, alcança a sabedoria e está finalmente pronto para assumir as atribuições que o destino Ihe reservou. No entanto, a divergência se estabelece no plano das aquisições: enquanto o iniciado, em sua viagem através da existência, descobre por si mesmo a complexa evolução do ser humano, o que Fama adquire, ao cabo de sua incursão pelo village, é a certeza da espoliação como acidente irreversível e, conseqüentemente, a inutilidade da luta contra um destino impiedoso que reservou para ele o triste atributo de dernier Doumbouya". A semelhança com os deslocamentos dos grandes heróis parece, no entanto, constar do programa narrativo como um meio de acentuar o

${ }^{272}$ L'univers urbain de la capitale cède la place au monde de la savane, de la brousse et du village et ces deux univers se manifestent comme totalement différents, voire opposés. (BORGOMANO, 1998, op. cit., p. 82). 
infortúnio de Fama, pois a viagem ao Togobala Ihe proporciona a aquisição fugaz ou parcial dos bens adquiridos pelos heróis das narrativas tradicionais. $O$ deslocamento efetivo de Fama - que compreende o trajeto, o tempo de permanência no Togobala e, finalmente sua decisão de retornar à capital - não restaura sua honra ou restitui o que Ihe foi usurpado senão de um modo parcial e precário:

Et Fama trônait, se rengorgeait, se bombait. Regardait-il les salueurs? A peine! Ses paupières tombaient en vrai totem de panthère et les houmba! Jaillissaient. Au petit de ce matin d'harmattan, au seuil du palais des Doumbouya, un moment, pendant un moment, un monde légitime plana ${ }^{273}$. Les salueurs tournaient. Fama tenait le pouvoir comme si la mendicité, le mariage avec une stérile, la bâtardise des Indépendances, toute sa vie passée et les soucis présents n'avaient jamais existé. ${ }^{274}$

Fama é estimulado por Diamourou, o griot dos Doumbouya, e por Balla, o feiticeiro, ennemi public d'Allah (KOUROUMA, LsdI, p. 111), a tomar posse de sua herança, a permanecer no village e reerguer Togobala. Balla e Diamourou tinham se tornado os únicos testemunhos dos grandes dias e da decrepitude da dinastia Doumbouya e, por essa razão, mesmo reconhecendo a degradação do espaço, investiram na reabilitação da tradição:

Au soir de leur vie les deux vieillards oeuvraient à la réhabilitation de la chefferie, au retour d'un monde légitme. Malheureusement, Togobala, les Doumbouya et même le Horodougou ne vallaient pas en Afrique un grain dans un sac de fonios. ${ }^{275}$

A restauração da cheferia tradicional parecia um caminho viável para Diamourou e Balla, enquanto Fama, mesmo tendo a oportunidade de reviver momentaneamente a experiência de um mundo legítimo, encontra na imagem do village a marca inequívoca de sua total destruição:

\footnotetext{
273 Grifos nossos.

274 KOUROUMA, LsdI, p. 110.

275 KOUROUMA, LsdI, p. 113.
} 
Du Togobala de son enfance, du Togobala qu'il avait dans le coeur il ne restait même plus la dernière pestilence du dernier pet. En vingt ans le monde ne s'était pourtant pas renversé. Et voilà ce qui existait. De loin en loin une ou deux cases penchées vieillottes, cuites par le soleil, isolées comme des termites dans une plaine. ${ }^{276}$

A decrepitude material é compartilhada pelos elementos da natureza e pela degradação dos habitantes:

Fama reconnut le baobab du marché. Il avait peiné, était décrepit lui aussi; le tronc cendré et lacéré, il lançait des branches nues, lépreuses vers le ciel sec, un ciel hanté par le soleil d'harmattan et par le vol des vautours... (...) Des habitants de tous âges accouraient, tous faméliques et séchés comme des silures de deux saisons, la peau rugueuse et poussiéreuse comme le margouillat des murs, les yeux rouges et excrémenteux de conjonctivite. ${ }^{277}$

Mas se os olhos de Fama contemplam apenas ruínas e degradação, onde estaria esse espaço organizado da tradição ? Hoje, essa organização tornou-se memória juntamente com os dias de glória do passado remoto de Fama. O que mais se aproxima da vida regrada da tradição encontra-se na articulação espaço-temporal dos quarenta dias de funerais de Lacina. A visita ao cemitério é a oportunidade do reencontro com os espíritos dos ancestrais que, na capital, não brindam mais os malinkés com sua presença; no espaço degradado, é o duplo, a sombra do falecido Ibrahima Koné que leva a mensagem ao mundo dos mortos:

L'ombre du décédé allait transmettre aux mânes que sous les soleils des Indépendances les Malinkés honnissaient et même giflait leur prince. Mânes des aïeux! Mânes de Moriba, fondateur de la dynastie! il était temps, vraiment temps de s'apitoyer sur le sort du dernier et légitime Doumbouya! $!^{278}$

\footnotetext{
${ }^{276}$ KOUROUMA, LsdI, p. 103.

277 KOUROUMA, LsdI, p. 103.

278 KOUROUMA, LsdI, p. 17.
} 
O ritmo acelerado e o espaço exíguo da capital não permitem sequer o merecido repouso daqueles que partiram; o cemitério da cidade negra era proporcional ao espaço reservado aos negros da cidade:

... les enterrés avaient un an pour pourrir et se reposer; au-delà on les exhumait. Une vie de bâtardise pour quelques mois de repos, disons que c'est un peu court. ${ }^{279}$

Se na capital, são os que partem que levam consigo as notícias de seus familiares; em Togobala, os ancestrais vêm ver o que ocorre no mundo dos vivos:

... Le soleil caressait les nuques et ses rayons sans raison prolongeaient les murmures en faisant pétiller les tombes et les feuilles jonchant le cimétière. C'était le susurrement des mânes et des doubles des enterrés sortant de l'autre monde pour s'asseoir et boire les prières. Une assemblée nombreuse et invisible entourait, pressait et étouffait les prieurs. Elle était grosse de tous les valereux et honorés aïeux Doumbouya. Cent fois piteux Fama devait leur paraître. ${ }^{280}$

Em Togobala, os mortos vêm beber as orações; na capital, não há nenhuma referência a tal aproximação entre o mundo dos mortos e mundo dos vivos, excetuando-se a presença do duplo do falecido que, espera, pacientemente, que os rituais se cumpram e tornem o além favorável à sua chegada.

Os funerais de quarenta dias representam, para Fama, o resgate, ainda que precário, dos ritos da tradição. Constatando a miséria na qual se transformaram os funerais dos malinkés após a colonização e a independência, Fama, Diamourou e Balla decidem preparar para o primo Lacina um ritual que garanta uma boa acolhida no mundo dos mortos e que seja digna das grandes tradições, banindo assim, mesmo que provisoriamente, a atual degradação dos rituais:

\footnotetext{
${ }^{279}$ KOUROUMA, LsdI, p. 25-26.

${ }^{280}$ KOUROUMA, LsdI, p. 116.
} 
Pourquoi les Malinkés fêtent-ils les funérailles du quarantième jour d'un enterré? Parce quarante jours exactement après la sépulture les morts reçoivent les arrivants mais ne lui cèdent une place et des bras hospitaliers que s'ils sont tous ivres de sang. Donc rien ne peut être plus bénéfique pour le partant que de tuer, de beaucoup tuer à l'occasion du quarantième jour. Avant les soleils des Indépendances et les soleils des colonisations, le quarantième jour d'un Malinké faisait déferler les marigots de sang. Mais maintenant avec le parti unique, l'indépendance, le manque, les famines et les épidémies, aux funérailles des plus grands enterrés on tue au mieux un bouc. Et quelle sorte de bouc ? très souvent un bouc famélique gouttant moins de sang qu'une carpe. Et quelle qualité de sang ? Du sang aussi pauvre que les menstrues d'une vieille fille sèche. C'était pour ces raisons que Balla aimait affirmer que tous les morts des soleils des Indépendances vivaient au serré dans l'au-delà pour avoir été tous mal accueillis par leurs devanciers. ${ }^{281}$

Se, por um lado, os griots, os presentes e os sacrifícios de sangue foram episódios bem sucedidos da cerimônia, por outro, o sinal do malefício foi trazido pelas aves esquecidas durante distribuição da carne dos sacrifícios, pretensamente feita com justiça e ponderação (KOUROUMA, LsdI, p. 142). Os pios estridentes lembravam a todos a negligência imperdoável. Além dessa nota dissonante, Fama constata a mediocridade da performance nas danças dos caçadores, um espetáculo que outrora animava a e enchia de admiração a audiência:

Mais asseyons-nous et restons autour du n'goni des chasseurs. Bâtardise! Vraiment les soleils des Indépendances sont impropres aux grandes choses; ils n'ont pas seulement dévirilisé mais aussi démystifié I'Afrique. II n'y eut aucune diablerie ébahissante, mais de toutes petites, comme celles que Fama avaient vues quatre-vingts fois parfaitement exécutées par un pretidigitateur toubab dans la capitale. (...) Mais aucun n'appela de la profonde brousse la féroce panthère ou le buflle solitaire jusque dans le cercle de danse, pour l'abattre. Aucune goute de sang! Une danse, un $n^{\prime}$ goni de chasseurs sans sang, disons-le, c'était décevant. ${ }^{282}$

Uma vez cumprido seu objetivo no Togobala e constatada a miséria de sua herança, Fama decide retornar à capital, a despeito das súplicas de Balla, que havia previsto para sua viagem o encontro com um destino desfavorável, realmente maléfico (KOUROUMA, LsdI, p. 146). De fato, Fama, em pouco

${ }^{281}$ KOUROUMA, LsdI, p. 138.

282 KOUROUMA, LsdI, p. 144. 
tempo, seria arbitrariamente envolvido em um complô contra o presidente e passaria então ao terceiro espaço do romance: o espaço carcerário.

A primeira imagem do cárcere é dada pelo campo sem nome, no qual Fama é confinado sem nenhuma referência de ordem geográfica ou temporal:

D'abord on y perdait la notion de la durée. Un matin, on comptait qu'on y avait vécu depuis des années; le soir on trouvait qu'on y était arrivé depuis des semaines seulement. Et cela parce qu'on y débarquait, toujours presqu'en mourant, l'esprit rempli de cauchemars, les yeux clos, les oreilles sourdes. Puis on y passait des jours plus longs que des mois, et des saisons plus courtes que des semaines. En pleine nuit le soleil éclatait; en plein jour la lune apparaissait. On ne réussissait pas à dormir la nuit, et toute la journée on titubait, ivre de sommeil. ${ }^{283}$

A omissão de referência temporal, que constitui uma das práticas freqüentes da tortura, persiste mesmo após a transferência da Fama para uma prisão de Mayako. Se o espaço carcerário passa a ser definido, o tempo de sua permanência na prisão continua sendo omitido. A restrição espacial e a suspensão temporal formam um quadro ideal para a transposição das ações para o mundo interior do personagem: Fama retoma suas reflexões sobre o fim da dinastia Doumbouya. Impotente com relação a tal evidência, resta-Ihe o universo onírico como meio de escapar à morte funcional:

Des journées entières passées à ruminer des idées aussi triste sur la mort remplissaient les nuits de Fama de rêves terribles.

Un matin, quelques instants avant le réveil, un songe éclata devant ses yeux. Et quel songe! On lui cria: "Regarde-toi! Regarde-toi! Tu es vivant et fort. Tu es grand. Admire-toi!"

A califourchon sur un coursier blanc, Fama volait, plutôt naviguait, boubou blanc au vent, l'étrier et l'éperon d'or, une escorte dévouée parée d'or l'honorait, le flattait. Vrai Doumbouya! Authentique! Le prince de tout le Horodougou, le seul, le grand, le plus grand de tous. Audessous fuyait un manque, un désir, quelque chose qui avait glissé à travers les doigts. Était-ce un cheval? Une femme? Fama se courba, se pencha, mais ne put rien distinguer, le manque filait comme le vent, il était luisant comme la traînée de queue d'un lointain feu de brousse. A bride abattue, Fama le poursuivait, peinait de le poursuivre; et cela fuyait, détalait plus vite, menaçait de disparaître, et sa disparition, on se le disait, laisserait I'univers orphelin, avec le malheur de la sécheresse

283 KOUROUMA, LsdI, p. 159. 
du coeur. Et pourtant Fama exultait, se pâmait de joie, se disant: "La chose court à sa perte, sur le chemin l'attend, solide comme un roc, celui qui l'accaparera."

Et énivré de joie Fama éclata de rire, d'un rire fou; il rit si fort qu'il se réveilla, et réveillé continua à s'esclaffler, à pouffer... ${ }^{284}$

Se a passagem do espaço organizado da tradição à geografia da exclusão enfatiza a decrepitude de uma aristocracia e a ascensão dos valores modernos, a morte da tradição não pode ser senão uma morte parcial. Fama retorna ao Horodougou para morrer como um verdadeiro Doumbouya, mas deixa no espaço urbano aqueles que carregam as matrizes da tradição, como símbolo do direito ao diverso como princípio de identificação.

${ }^{284}$ KOUROUMA, LsdI, p. 171. 


\section{CONCLUSÃO: das preces à aceleração temporal}

O romance Les soleils des Indépendances foi, inicialmente, concebido como uma luta política, uma denúncia contra os abusos da tirania dos governos que sucederam o processo de independência dos paises africanos de colonização francesa.

Do ponto de vista histórico, Kourouma enfatiza as decepções e turbulências políticas de um período marcado pela corrupção e pelo autoritarismo. Como ator engajado desse processo histórico, Kourouma organiza sistematicamente as experiências pessoais e coletivas dos indivíduos que tiveram o rumo de suas vidas alterado pela penetração colonial, compreendida como uma ruptura da História e do destino de um continente. Como afirma Bakhtin (1993, p. 29), é no relacionamento e na orientação direta para a unidade da cultura que o fenômeno [cultural] deixa de ser um mero fato, simplesmente existente, adquire significação, sentido, transforma-se como que numa mônada que reflete tudo em si e que está refletida em tudo. Se o objetivo do autor, em sua primeira incursão pela literatura, é elaborar a ficção de modo a estigmatizar a colonização e a era das independências, os procedimentos de seleção de dados da realidade e a organização estética desses elementos não poderiam deixar de enfatizar as rupturas que se estabeleceram, em vários planos, como refração do ato inicial, ou seja, o descredenciamento da organização econômica, social, política e cultural da tradição pela dominação francesa. Assim, o objeto literário é construído de modo que o eixo paradigmático que compreende a intervenção histórica, a espoliação, a esterilidade e a morte, reflete a responsabilidade dos colonizadores e dos dirigentes africanos da era das independências pelo estado de miséria, decadência e morte de uma África ancestral. Guiado pela responsabilidade cívica, Kourouma pretende elaborar um mundo de significações antitéticas que possam servir a seu objetivo de denúncia e exposição da real situação dos países africanos após as independências. No entanto, a despeito de sua decepção com os estudos etnográficos e 
sociológicos sobre a África e de sua necessidade de expor, de testemunhar e denunciar ${ }^{285}$ as mazelas políticas da África causadas pelos europeus, Kourouma não elabora um documento científico, mas a ficção que se inscreve na tendência realista dos romances africanos de língua francesa. Como afirma Jacques Dubois, o romance realista, mesmo que não seja tão mimético quando pretenda ser, isso não o impede de nos revelar muitos dados a respeito de uma realidade sempre ancorada na História e de tentar apreender a verdade dos fatos ${ }^{286}$. Quando ele atinge o limite daquilo que o move, torna-se instrumento incomparável de análise das engrenagens e dos mecanismos sociais. $^{287}$

O romance africano não poderia, portanto, deixar de refletir a transculturação resultante do encontro da cultura ocidental com a tradição africana. Como uma narrativa que tem pretensões a um compromisso com 0 real, o romance de Kourouma aponta para uma organização que ultrapassa a própria base de seu projeto: a ruptura como interrupção de determinado fluxo contínuo já anuncia uma gama de inter-relações de outra natureza, ou seja, o contexto da pluralidade cultural obriga a deslocamentos e sínteses provisórias das identidades que escapam à oposição maniqueísta entre tradição e modernidade. Aliás, esse caráter dinâmico da identidade de uma sociedade não era exatamente uma novidade para os povos do Mandingue, pois, como prova o processo de islamização da região, em seu espaço, raças, etnias e classes sociais se misturaram, e com elas, culturas diversas (MEMEL-FOTÊ, 1977, p. 65). ${ }^{288}$

\footnotetext{
285 Cf. nota 18 .

${ }^{286}$ Cf. Walter Burckert e a utilização de narrativas de ficção como forma de suprir a deficiência de documentos históricos, p. 71 deste documento.

${ }^{287}$ Que le roman réaliste ne soit guère aussi mimétique qu'il le prétend ne l'empêche pas de nous en dire beaucoup sur une réalité toujours ancrée dans l'Histoire et de tenter d'en cerner la vérité. Quand il va jusqu'au bout de ce qui le meut, il est un instrument hors pair d'analyse des rouages et des mécanismes sociaux. (DUBOIS, Jacques. Les romanciers du réel: De Balzac à Simenon. Paris: Seuil, 2000. p. 11).

${ }^{288}$ Dans leur espace, des races, des ethnies, des classes sociales se sont mêlées et avec celles-ci des cultures diverses. MEMEL-FOTÊ Harris. La bâtardise. In : M'LANHORO, Joseph. (org.) Essai sur Les soleils des indépendances. Abidjan:
} 
Em "Dinâmica das identidades", acompanhamos o processo de constituição das grandes nações européias que impôs ao indivíduo que outrora podia "identificar-se", de modo satisfatório e inquestionável, como membro de uma família, de uma religião, de uma tribo, ou micro-organização social e política, um princípio de nacionalidade e de identidade vinculado às grandes nações. A equação ideal dessa transformação encontrava-se na imposição de uma língua que adquiriu o status vernacular e na supressão da identificação ou sentimento de pertença com as sociedades tradicionais. Nessa passagem da identificação com as micro-estruturas sociais ao elemento aglutinador da "nacionalidade", o indivíduo viveu a experiência do deslocamento de seu sentimento de pertença: a identificação com a estrutura tradicional, tribal, foi substituída pela identificação com uma comunidade artificialmente organizada. No entanto, tal passagem certamente não significou um movimento desprovido de conflitos para os atores deste momento histórico, como não significaria, mais tarde, para todas as comunidades que vivenciaram um processo similar a este. A título de exemplo, citamos a experiência narrada por Zygmunt Bauman em seu livro Identidade:

Pouco antes de a última guerra mundial irromper, realizou-se um censo na minha Polônia natal, então uma sociedade multiétnica. Certas partes do país eram habitadas por uma inusitada mistura de grupos étnicos, credos religiosos, línguas e costumes. Dar uma nova feição a essa mistura, por meio da conversão e assimilação forçadas, numa nação uniforme ou quase uniforme segundo, digamos, o modelo francês, talvez fosse um objetivo energicamente perseguido por uma parte da elite polonesa, mas de maneira alguma um propósito universalmente aceito e consistentemente apoiado, muito menos um projeto próximo de sua conclusão. ${ }^{289}$

Durante a coleta de dados do censo, as pessoas entrevistadas não conseguiam entender o sentido da palavra nacionalidade, nem o que significava pertencer a uma nação, e davam a esse item a única resposta que

NEA, [1974]. p. 65). Sobre a formação e a História da região do mandingue, ver "Povo e cultura malinké", na primeira parte deste trabalho.

289 BAUMAN, 2005, op. cit., p. 23. 
podiam conceber como verdadeira: somos daqui, somos deste lugar, pertencemos a este lugar (BAUMAN, 2005, p. 24). Com o objetivo de provar que esse episódio não foi peculiar a seu país de origem, o autor cita ainda uma pesquisa realizada na França, cujos resultados mostraram que, após dois séculos de um persistente processo de construção nacional, "le pays", para muitos camponeses, tinha [aproximadamente] vinte quilômetros de diâmetro. Em resumo, o que Bauman pretende provar efetivamente é que, no interior dessa rede de familiaridade do berço ao túmulo, o lugar de cada pessoa era evidente demais para ser avaliado, que dirá negociado. ${ }^{290}$

Como vimos ainda nas discussões sobre a dinâmica das identidades, a idéia que um indivíduo faz de si mesmo está intimamente ligada à noção de pertencimento a uma determinada comunidade e ao reconhecimento que define sua identidade. A partir do momento em que esse pertencimento é questionado em nome de uma força de organização externa, supostamente mais eficaz do que a anterior, o indivíduo se encontra diante da possibilidade de integrar-se à nova ordem de comando ou manter-se refratário a ela, mas sujeitar-se, com isso, a um sentimento autodepreciativo, induzido e bem alimentado pelos mecanismos de opressão, como ocorreu com os negros, os índios e todos os povos subjugados pela colonização. O romance de Kourouma nos mostra um personagem que se insere no segundo modelo de relacionamento com essa nova ordem.

Com o objetivo de criar um universo fictício que estigmatizasse, tanto quanto possível, a colonização e a era das independências, Kourouma mostra a trajetória de um indivíduo refratário à modernidade não apenas porque ela se sobrepôs ao mundo das tradições, mas também porque não recebe nenhum tipo de reconhecimento que autorize a retomar o prestígio e o poder que lhe foram usurpados. Uma vez que a imagem degradante ou depreciativa que a sociedade faz de um indivíduo pode causar lhe causar sérios danos (TAYLOR, 2001, p. 43), Fama encarna a concepção que a nova sociedade faz do legítimo

290 BAUMAN, 2005, idem, p. 24. 
descendente dos príncipes Doumbouya: a imagem grotesca de um príncipe reduzido à mendicância e coberto de vergonha pelo ódio e desprezo públicos.

Como sujeito concentrado no ultraje da espoliação, Fama não admite a existência dos "entre-lugares" que permitem a negociação dos valores culturais como meio de elaboração de estratégias de subjetivação - singular ou coletiva - que dão início a novos signos de identidade. (BHABHA, 2003, p. 20).

A análise do romance nos permitiu observar que a possibilidade dessa negociação não existe para Fama, visto que "negociar" implica a existência de um acordo entre as partes e a necessidade de um mínimo de concessão. Se o "entre-lugar" se tornou uma realidade com a chegada e a penetração dos europeus no continente africano, os termos de uma possível negociação que, eventualmente, ofereceria a ocasião para que Fama pudesse elaborar novas estratégias de subjetivação, não são aceitos. Se o que o Estado oferece uma cédula de identidade como meio de identificação individual, Fama não concebe que possa haver algo que suplante sua identidade tradicional, criada a partir dos laços de sangue e de suas prerrogativas reais e hereditárias. Se, por outro lado, Fama "cede" em alguns momentos e se diz disposto a compor com o governo e a economia da nova ordem, esta não reconhece sua aptidão para assumir os únicos cargos aos quais se submeteria: a secretaria de uma subseção do partido único ou a direção de uma cooperativa. Com a exposição da vida psíquica de seu personagem principal, é possível compreender a maioria de suas atitudes e reações, mas, como vimos no capítulo "Do herói épico ao príncipe decaído", mesmo que o funcionamento psíquico do personagem seja cuidadosamente explicitado, algo sempre nos escapa, a exemplo do que ocorre no mundo real. Assim sendo, a dúvida sobre essa suposta concessão de Fama permanece: não é possível afirmar se Fama teria cedido à oferta da nova ordem por traição aos princípios da tradição, por fidelidade à duplicidade malinké ou simplesmente para ser absorvido pela nova ordem e obter finalmente um reconhecimento. De qualquer modo, mesmo que tais possibilidades possam ser aceitas como razões distintas, mas não excludentes entre si e, havendo portanto a possibilidade de que todas sejam 
verdadeiras, existe ainda nessa concessão de Fama o comprometimento de sua concepção ideológica. Assim, para o indivíduo que se debate em prol da tradição, da restauração da cheferia e dos dias de glória dos Doumbouya, "ceder" em seus princípios para obter vantagens pessoais significa "negociar" em termos bem distintos daqueles que são propostos por Homi Bhabha, significa corromper-se com vistas à obtenção de algum tipo de lucro. Talvez tenha sido essa a razão que levou Kourouma a ceder um lugar tão significativo a Salimata no espaço do romance. Se, por um lado, ela divide com o marido a frustrante experiência da esterilidade, por outro, sua personalidade se desenha como algo infinitamente mais coerente e mais digno do que a concepção que possamos ter de Fama.

Salimata é o exemplo da integração ao novo contexto da vida na capital. Uma vez que às mulheres não é dado imiscuir-se das decisões políticas e sociais, sua adaptação compreende um traço específico da condição da mulher africana: a submissão ao marido e às circunstâncias advindas desse relacionamento. Além disso, Salimata, em seu desvelo no cumprimento de seu papel de mulher, compromete-se com os cuidados devidos ao marido a ponto de sustentá-lo com seu trabalho remunerado, o que a obriga a adaptar-se também à demanda do mercado onde trabalha e, conseqüentemente, ao ritmo e aos horários da capital. A coerência do personagem encontra-se, portanto, naquilo que impulsiona seus atos e sua conduta, ou seja, naquilo que atende a uma exigência de sua identidade social. Seja nas atividades quotidianas, seja no combate à esterilidade, Salimata tenta realizar um determinado ideal feminino que compreende a docilidade da esposa e a realização da função da mulher expressa na maternidade. Mesmo nos momentos em que se deixa levar pela ira e explode em reações violentas contra o marido ou a co-esposa, Salimata não foge à concepção da mulher malinké, pois, como vimos, a agressão e a violência são traços típicos da personalidade do grupo e, portanto, se refere também as mulheres.

Retomando a questão da negociação dos termos que definem uma identidade individual em meio à pluralidade, podemos dizer que Salimata é o 
personagem melhor realiza a negociação dos valores culturais. Mesmo fiel ao ideal feminino africano, ela consegue se adaptar ao meio híbrido e conciliar demandas, em princípio, contraditórias: o respeito às exigências de um perfil feminino tradicional e a adaptação à organização econômica e urbana da modernidade, que ignora os princípios tradicionais.

Ao citarmos o processo de expansão e unificação das grandes nações do ocidente, propomos uma comparação com o processo de formação das nações africanas tendo como base o dado comum da depreciação de comunidades consideradas "inferiores e atrasadas" (MILL, apud Hobsbawm, 2004:46). A supressão das comunidades menores em benefício da constituição das grandes nações européias foi metaforicamente identificada por Bauman como o momento da substituição de um sólido por outro ou, em outros termos, a sobreposição da natividade aos laços de sangue. A partir desse momento, indivíduo deixa de contar uma identificação satisfatória e inequívoca e passa a ser reconhecido por sua resposta à exigência de lealdade e à subordinação exigidas pela Nação à qual se vincula.

Podemos dizer que o contexto histórico escolhido como referente do primeiro romance de Ahmadou Kourouma compreende igualmente essa substituição de um sólido por outro. Encontramos especial apoio para essa comparação na medida em que a atuação do colonizador reproduz os movimentos e estratégias das elites das grandes nações européias: ele impõe uma atividade missionária de civilização de populações que considera "inferiores e atrasadas" como subterfúgio para a expansão territorial e conseqüente exploração econômica. Nesse aspecto, a colonização também mantém um elo de identificação com o conceito liberal de nação, que vinculava sua expansão às necessidades da economia e à promoção dos vários ramos de produção. Sob um outro ângulo, Gérard Dago Lézou faz uma comparação entre as circunstâncias que proporcionaram o surgimento do indivíduo problemático e a situação política que propiciou o nascimento das literaturas africanas, identificando a semelhança entre esses dois processos: 
O romance africano nasceu de um conflito, o da colonização, mas foi necessário que, em primeiro lugar, o colonizado se conscientizasse da existência desse conflito e assumisse sua sociedade. Em outros termos, uma vez que a sociedade recebeu novos valores, o indivíduo que não se adapta ao novo ambiente sente-se ameaçado. Temos então uma sociedade "degradada" que torna o indivíduo "problemático", no sentido em que Goldman emprega esses termos. Fenômeno que o ocidente conheceu na era industrial. ${ }^{291}$

Como meio de solucionar esse conflito, a evocação do real torna-se fundamental, não constituindo, portanto, uma peculiaridade de Kourouma. Mas, considerando-se o contexto histórico e político da África, em geral, e da Costa do Marfim, em particular, bem como os elementos culturais que compõem a obra, sentimo-nos inclinados a dizer que o autor organiza os elementos estéticos com tal habilidade que muito pouco escapa à sua preocupação de revelar a verdade política e social da era das independências. No nosso caso, o que lhe escapa em termos de organização deliberada do material estético é precisamente o que nos interessa. Quando nos referimos à metáfora de Bauman, enfatizamos a questão da substituição de um sólido por outro a fim de aproximar sua leitura da expansão das grandes nações européias com o processo de imposição colonial operada no continente africano. Mas sua metáfora não se restringe a esse estado da matéria e indica a liquefação como meio mais adequado de ilustrar o processo de derretimento dos sólidos da modernidade tardia. Essa interpretação da pós-modernidade compreende ainda a sobreposição do tempo ao espaço e, posteriormente, a aceleração temporal que conduz inevitavelmente à rapidez nas negociações entre os indivíduos e à fugacidade e fragilidade dos laços afetivos. Esse seria

${ }^{291}$ Le roman africain est né d'un conflit, celui de la colonisation, mais il a fallu d'abord que le colonisé prenne conscience de ce conflit et qu'il assume sa société. En d'autres termes, la société ayant été investie de nouvelles valeurs, l'individu en désaccord avec son environnement immédiat, ne se sent plus en sécurité. Nous avons une société " dégradée » qui rend l'individu «problématique», au sens où Goldmann emploie ces termes. Phénomène qu'a connu l'Occident à l'ère industrielle. (LÉZOU apud PARFAIT. In: PARFAIT, Diandue $\mathrm{Bi}$ Kacou. Histoire et fiction dans la production romanesque d'Ahmadou Kourouma. 2003. Thèse (Doctorat en Sciences de l'Homme et de la Société) - Faculté des Lettres - Département de Littérature générale et comparée, Université de Limoges, Limoges. 2003. Não paginado). 
então o perfil do homem pós-moderno, o homem das relações globalizadas e dos mundos livres de suas cercas e barreiras, que propicia a fluidez dos laços sociais e das técnicas de poder.

Segundo nossas análises, acreditamos agora poder afirmar que, se o processo de transferência de lealdade e identificação das sociedades tradicionais às culturas nacionais é evidente no primeiro romance de Kourouma pela própria relação ao referente histórico, alguns dados também apontam para a incidência de processos que ocorriam no ocidente no momento das independências africanas. Para Stuart Hall (2003, p. 23), as concepções mutantes do sujeito surgidas do século XX correspondem à evolução que levou o sujeito da estabilidade à fragmentação. Segundo Bauman, à instabilidade, à variabilidade e à mutação das identidades, é preciso acrescentar o aspecto cambiante da relação espaço-tempo. Assim, privilegiando segundo essa noção baumaniana, analisamos o processo de mutação social e cultural revelado pela relação espaço-temporal da ficção. Constatamos que, dentre as estratégias de ruptura empregadas na construção de Les soleils des Indépendances, o desmantelamento da organização espacial serve, em primeiro lugar, ao propósito político e ideológico do autor: o espaço "organizado" da tradição se mostra efetivamente como um espaço em ruínas, ou seja, o processo de degradação se mostra irreversível; quanto ao espaço urbano, característico dos novos tempos por ser filho "legítimo" da modernidade, este já nasce degradado e segregacionista: para os europeus o conforto, para os negros, que são os "legítimos herdeiros" da terra africana, a periferia do espaço urbano, mal concebido e sem saneamento básico.

Com relação à questão temporal, a cronologia ocidental substituiu a marcação temporal da tradição, baseada no ritmo da natureza e nas horas das preces muçulmanas. Assim, Salimata se submete ao ritmo da capital na medida em que essa nova marcação temporal não entra em conflito com os princípios da tradição aos quais está habituada. Quanto a Fama, mesmo vivendo na capital, continua a obedecer ao ritmo da tradição, a dividir seu dia segundo as horas das preces, como fazia no Togobala. Aliás, como a tradição é 
o princípio que rege a psicologia do personagem, mesmo no final do romance, quando abandona a capital para morrer no Horodougou, sua concepção do espaço da capital remete, de certa forma, ao espaço fechado da tradição:

Il se releva, se pencha pour saisir, reconnaître un seul toit, un seul arbre, une seule rue ou un seul pont. Maintenant c'était fini; il était parti, il fallait jeter un dernier regard sur ce qui enfermait Salimata. ${ }^{292}$

Se, por um lado, o grau de ligação de Fama com a tradição e sua dificuldade de inserção na vida política e social da capital impedem sua adequação à nova ordem de mestiçagem cultural, por outro, Salimata assume e se integra ao novo contexto social no momento que representou, para a História recente da África, a substituição de um sólido por outro ou, em outras palavras, a substituição da tradição pela modernidade da era colonial. Além dessa composição binária que, sem dúvida, reflete a realidade contextual do romance e contribui, ao mesmo tempo, para a realização do objetivo do autor, apontamos no capítulo "Da mulher africana aos costumes ligeiros" o personagem que subscreve nossa hipótese da inserção, subliminar, dos laços frágeis e efêmeros da modernidade líquida. Papillon, um personagem a priori sem grande interesse dramático, encarna, em sua rápida participação na trama, a era da fluidez e dos contatos breves. Sua reação à preleção de Bakary (KOUROUMA, LsdI, p. 177-178) revela o comportamento do sujeito que despreza os apoios estáveis da tradição e é guiado por uma certa labilidade nas relações, antecipando assim uma característica da liquefação das relações, que nomeamos aqui como "laços efêmeros". Como dissemos nas análises referentes a este personagem, o perfil de Papillon se inscreve na obra como uma configuração não programada do autor, mas que aponta para uma aceleração do processo de modernidade devido aos influxos ocidentais.

292 KOUROUMA, LsdI, p. 186. 


\section{REFERÊNCIAS BIBLIOGRÁFICAS}

ADIAFFI, Jean-Marie. La carte d'identité. Abidjan: CEDA, 1980. 159 p.

AHUA, Bernard. La France se taille la part du Lion dans l'économie ivoirienne. In : LE MONDE DIPLOMATIQUE : Manière de voir 79. Résistences africaines. Paris, [s.n.], n. 79, fév.-mars 2005, p. 85.

ALEXANDRE, Pierre. Griots. In : BALANDIER, Georges et MAQUET, Jacques (Dir.). Dictionnaire des civilisations africaines. Paris : Fernand Hazan, 1968. p. 192-194.

AMON D'ABY, François-Joseph. Le problème des chefferies en Côte d'Ivoire. Abidjan : NEA, 1988. 62 p.

AZIZA, Mohamed. (Org.). Patrimoine culturel et création contemporaine en Afrique et dans le monde arabe. Dakar: NEA, 1977. 247 p.

BADIAN, Seydou. (1963) Sous l'orage (Kany) - suivi de La mort de Chaka. Paris: Présence Africaine, 1972. 253 p.

BAKHTIN, Mikhail. Questões de literatura e de estética: A teoria do romance. Tradução: Aurora Fornoni Bernadini et al. 3. ed. São Paulo: Edusp; São Paulo: Hucitec, 1993. 439 p. (Linguagem e Cultura).

Estética da criação verbal. Tradução feita a partir do francês: Maria Ermantina Galvão G. Pereira. 2. ed. São Paulo: Martins Fontes, 1997. 421 p. Título original: Estetika slovesnogo tvortchestva. (Ensino Superior).

BALANDIER, Georges et MAQUET, Jacques (Dir.). Dictionnaire des civilisations africaines. Paris : Fernand Hazan, 1968. 448 p.

BAMBA, Kassimi. Le drame des enfants soldats en Afrique. In : DÉBATS: Courrier de I'Afrique de I'Ouest. Abidjan: CERAP/ Inades, n. 22, fév. 2005. p. 21-24.

BARTHES, Roland. Essais critiques. Paris: Seuil, 1964. 276 p.

. Le Degré zéro de I'écriture: suivi de Nouveaux essais critiques. 2. ed. Paris: Seuil, 1972. 187 p. 
. Le bruissement de la langue: Essais critiques IV. Paris: Seuil, 1984. 439 p.

BAUMAN, Zygmunt. Modernidade líquida. Tradução: Plínio Dentzien. Rio de Janeiro : J. Zahar, 2001. 258 p. Título original: Liquid modernity.

. Identidade: Entrevista a Benedetto Vecchi. Tradução: Carlos Alberto Medeiros. Rio de Janeiro : J. Zahar, 2005. 110 p. Título original : Identity (Conversations with Benedetto Vecchi).

BENIAMINO, Michel. La francophonie littéraire: Essai pour une théorie. Paris: Karthala, 1999. 462 p.

BHABHA, Homi K. O Iocal da cultura. Tradução: Myriam Ávila et al. Belo Horizonte: Editora UFMG, 2003. 395 p. Título original: The Location of Culture.

BOKIBA, André-Patient. Écriture et identité dans la littérature africaine. Paris: L'Harmattan, 1998. 287 p.

BONI, Tanella. Écrivains et artistes francophones: pour qui ? Et pour quoi ? In: HUANNOU, Adrien (Textes réunis par). Francophonie littéraire et identités culturelles: Actes du colloque du Grelef (Cotonou, 18-20 mars 1998). Paris: L'Harmattan, 2000. p. 155-167.

BORGES, Jorge Luis. Esse Ofício do verso. Organização: Calin-Andrei Mihailescu. Tradução: José Marcos Macedo. São Paulo: Companhia das Letras, 2000. 159 p. Título original: This craft of verse.

BORGOMANO, Madeleine. Ahmadou Kourouma: Le "guerrier" griot. Paris: L'Harmattan, 1998. 252 p.

. Des hommes ou des bêtes: Lecture de En attendant le vote des bêtes sauvages, d'Ahmadou Kourouma. Paris: L'Harmattan, 2000. 201 p.

BRAHIMI, Denise. Conversation avec Tahar Ben Jelloun. In: NOTRE LIBRAIRIE : Revue du livre : Afrique, Caraïbes, Océan Indien. 1980 - 1990 : Dix ans de 
Littérature : I. Maghreb - Afrique Noire. Paris : Clef, n. 103, p. 41-44, oct.-déc. 1990.

BRAHIMI, Denise; TREVARTHEN, Anne. Les femmes dans la littérature africaine: Portraits. Préface: Catherine Coquery-Vidrovitch. Paris: Karthala; Abidjan: CEDA, 1998. 238 p.

BURKERT, Walter. Antigos cultos de mistério. Tradução: Denise Bottman. São Paulo: EDUSP, 1991. 144 p. Título original: Ancient Mistery Cults.

BUTOR, Michel. Essais sur le roman. Paris: Gallimard, 2003. 184 p.

CAILLOIS, Roger. Le mythe et I'homme. Paris: Gallimard, 1972. 188 p.

CAMARA, Sory. Paroles très anciennes ou le mythe de l'accomplissement de I'homme. Grenoble: La pensée sauvage, 1982. 219 p.

. Gens de la parole: Essai sur la condition et le rôle des griots dans la société malinké. Paris: ACCT; Paris: Karthala; Conakry: SAEC, 1992. $375 \mathrm{p}$.

CAMPROUX, Charles. Préface. In : BADIAN, Seydou. (1963) Sous I'orage (Kany) - suivi de La mort de Chaka. Paris: Présence Africaine, 1972. p. 9-12.

CANDIDO, Antonio. A educação pela noite e outros ensaios. 3. ed. São Paulo: Ática, 2003. 223 p. (Temas, v. 1. Estudos Literários).

. Literatura e sociedade: estudos de teoria e história literária. 7. ed. São Paulo: Nacional, 1985. 193 p.

CABAKULU, Muamba. (Traduits et rassemblés par). Le grand livre des proverbes africains. Avant-propos: Ahmadou Kourouma. Dessins originaux: Zaü. Paris: Presses du Châtelet, 2003. 318 p.

CASANOVA, Pascale. A República Mundial das Letras. Tradução: Marina Appenzeller. São Paulo: Estação Liberdade, 2002. Título original: La République mondiale des Lettres. 436 p.

CHAMOISEAU, Patrick. Écrire en pays dominé. Paris: Gallimard, 1997. 351 p. (Folio, 3677). 
CISSÉ, Youssouf Tata. L'Afrique, terre inconnue. In : NOTRE LIBRAIRIE : Revue du livre: Afrique, Caraïbes, Océan Indien. Écrivains de langue française : Afrique noire, Maghreb, Caraïbes, Océan Indien. Paris : Clef, n. 108, jan.-mars 1992. p. 12-18.

CLIFFORD, James. A experiência etnográfica: antropologia e literatura no século XX. Organização e revisão técnica: José Reginaldo Santos Gonçalves. Tradução: Patrícia Farias. Rio de Janeiro: UFRJ, 1998. 319 p.

CONDÉ, Maryse. La création littéraire en Afrique. In : AZIZA, Mohamed. (Org.). Patrimoine culturel et création contemporaine en Afrique et dans le monde arabe. Dakar: NEA, 1977, p. 13-32.

COSTA LIMA, Luiz. Mímesis e modernidade: formas das sombras. Prefácio: Benedito Nunes. Colaboração especial: Flora Süssekind. 2. ed. at. São Paulo: Paz e Terra, 2003. 295 p.

COQUERY-VIDROVITCH, Catherine. Préface. In : KIPRÉ, Pierre. Villes de Côte d'Ivoire: 1893-1940 : Fondation des villes coloniales. Préface : Catherine Coquery-Vidrovitch. Abidjan - Dakar - Lomé: NEA, 1985a. Tome I. p. 3-4.

DADIÉ, Bernard. (1966) Légendes et poèmes: Afrique debout; Légendes africaines; Climbié; La Ronde des jours. Paris : P. Seghers, 1973. 257 p.

DAILLY, Christophe. Devins et guérisseurs dans la littérature négro-africaine. In: REVUE DE LITTÉRATURE ET D'ESTHÉTIQUE NÉGRO-AFRICAINES. Institut de Littérature et d'esthétique Négro-Africaines. Abidjan : NEA, n. 4, 1982. p. 67-80.

DAMATO, Diva. Edouard Glissant: poética e política. Prefácio: Edouard Glissant. São Paulo: Annablume: FFLCH, 1995. (Parcours). 303 p.

DEMBÉLÉ, Salimata Kéïta. Excision, Douleur de Femme: Pour une stratégie de communication en faveur de la lutte contre l'excision en Côte d'Ivoire. Abidjan: EDILIS, 2001. 119 p.

DERIVE, Jean. La gestuelle dans les soleils des Indépendances. In : LEZOU, Gérard Dago et al. Sémiologie du corps romanesque dans Les soleils 
des Indépendances, d'Ahmadou Kourouma. Abidjan: EDUCI, 2002. p. 79-154.

DELEUZE, Gilles; GUATARRI, Félix. Mille plateaux: Capitalisme et Schizophrénie. Paris: Minuit, 1980. 645 p.

DONGALA, Emmanuel Boundzéki. L'étonnante et dialéctique déchéance du camarade Kali Tchikati. In: Jazz et vin de palme. Paris : Hatier, 1982. p. 7-34.

DUBOIS, Jacques. Les romanciers du réel: De Balzac à Simenon. Paris: Seuil, 2000. 358 p. (Points Essais, 434).

ELIADE, Mircea. Mito do eterno retorno. Tradução: José Antonio Ceschin. São Paulo: Mercuryo, 1992. 175 p. Título original: The Myth of the Eternal Return.

FIGUEIREDO, Eurídice; PRATI DOS SANTOS, Eloína. (Org.). Recortes transculturais. Niterói: EDUFF: ABECAN, 1997. 149 p.

- Construção de identidades pós-coloniais na literatura antilhana. Niterói: EDUFF, 1998. 166 p. (Ensaios, 12).

. (Org.). Conceitos de literatura e cultura. Juiz de Fora: UFJF; Niterói: EdUFF, 2005. 490 p.

FANON, Frantz. Les damnés de la terre. Préface: J.-P. Sartre. Paris: Découverte, 1987. 234 p.

FANTOURÉ, Alioum. Le cercle des tropiques. Paris: Présence Africaine, 1972. $315 \mathrm{p}$.

FERRET, Stéphane. (Introduction, choix de textes, commentaires, vade-mecum et bibliographie). L'identité. Paris: Flammarion, 1998. 239 p. (Corpus, 3030).

. Le philosophe et son scalpel: Le problème de l'identité personnelle. Paris: Minuit, 1993. $112 \mathrm{p}$.

FOUCAULT, M. L'archéologie du savoir. Paris: Gallimard, 1969. 275 p. 
. Qu'est-ce qu'un auteur. In: Dits et écrits. Paris : Gallimard, 1994. p. 789-821.

FONKOUYA, Romuald. Dix ans de littérature africaine : pouvoir, société et écriture. In : NOTRE LIBRAIRIE : Revue du livre : Afrique, Caraïbes, Océan Indien. 1980 - 1990 : Dix ans de Littérature : I. Maghreb - Afrique Noire. Paris : Clef, n. 103, p. 70-78. oct.-déc. 1990.

GARINE, Igor. Mali. In : BALANDIER, Georges et MAQUET, Jacques (Dir.). Dictionnaire des civilisations africaines. Paris : Fernand Hazan, 1968. p. 258-260.

GASSAMA, Makhily. Kuma: interrogation sur la littérature nègre de langue française (poésie-roman). Dakar-Abidjan: NEA, 1978. 343 p.

. La langue d'Ahmadou Kourouma ou le francais sous le soleil d'Afrique. Préface: Jean Ziegler. Paris: Karthala; ACCT, 1995. 123 p.

GLISSANT, Edouard. La lézarde. Paris: Seuil, 1958. 264 p. (Points, P 65). . Le discours antillais. Paris: Gallimard, 1997a. 839 p. (Folio Essais, 313).

. Poétique de la relation. In: Le discours antillais. Paris: Gallimard, 1997b. p. 325-464. (Folio Essais, 313).

GNAOULÉ-OUPOH, Bruno. La littérature ivoirienne. Paris: Karthala; Abidjan: CEDA, 2000. 444 p.

GOURDEAU, J.-P. Les religions. In : M'LANHORO, Joseph. (org.) Essai sur Les soleils des indépendances. Abidjan: NEA, [1974]. p. 67-80.

HALL, Stuart. A identidade cultural na pós-modernidade. Tradução: Tomaz Tadeu da Silva; Guacira Lopes Louro. 7. ed. Rio de Janeiro: DP\&A, 2003. 102 p. Título original : The question of cultural identity.

HAMIDOU KANE, Cheikh. L'Aventure ambiguë. Préface : Vincent Monteil. Paris: Julliard, 2005. 1961 p. $(10 / 18,617)$.

. Les gardiens du temple. Abidjan: NEI, 1996. 310 p. 
HAMPATÉ BÂ, Amadou. L'étrange destin de Wangrin : ou Les Roueries d'un interpète africain. Paris: 10/18, 1992. 382 p.

HOBSBAWN, Eric J. Nações e Nacionalismo desde 1780: Programa, mito e realidade. Tradução: Maria Célia Paoli; Anna Maria Quirino. 4. ed. Rio de Janeiro: Paz e Terra, 2004. 230 p. Título original: Nations and Nacionalism since 1780 - Programme, myth, reality.

HUANNOU, Adrien. La question des littératures nationales en Afrique noire. Abidjan : CEDA, 1989. 202 p.

- (Textes réunis par). Francophonie littéraire et identités culturelles: Actes du colloque du Grelef (Cotonou, 18-20 mars 1998). Paris: L'Harmattan, 2000. 167 p.

JOUANNY, Robert. Singularités francophones: ou choisir d'écrire en français. Paris: PUF, 2000. 182 p. (Écritures francophones).

KAUDJHIS-OFFOUMOU, Françoise ; NKIRANUYE, Jean Emile. L'excision en question. In : DÉBATS : Courrier de I'Afrique de I'Ouest. Abidjan : CERAP/ Inades, n. 32, fév. 2006. p. 15-20.

KESTELOOT, Lilyan. Les écrivains noirs de langue française: naissance d'une littérature. Bruxelles: Editions de I'Université de Bruxelles, 1983. $340 \mathrm{p}$.

. Histoire de la littérature négro-africaine. Paris: Karthala - AUF, 2001. 386 p.

KINDLER, Anna M. Multiculturalismo e formação da identidade cultural. In: FIGUEIREDO, Eurídice; PRATI DOS SANTOS, Eloína. (Org.). Recortes transculturais. Niterói: EDUFF: ABECAN, 1997. p. 13-26.

KIPRÉ, Pierre. Villes de Côte d'Ivoire: 1893-1940 : Fondation des villes coloniales. Préface : Catherine Coquery-Vidrovitch. Abidjan - Dakar Lomé: NEA, 1985a. Tome I. 238 p. 
: Économie et sociéte urbaine. Abidjan - Dakar - Lomé: NEA, 1985b. Tome II. 290 p.

KI-ZERBO, Joseph. A quand I'Afrique ?: Entretien avec René Holenstein. La Tour d'Aigues: I'Aube, 2003. 199 p.

KONÉ, Amadou. Du récit oral au roman: Etude sur les avatars de la tradition héroïque dans le roman africain. Abidjan: CEDA, 1985. 150 p. (EssaisDocuments-Recherches).

KONÉ, Mariatou et KOUAMÉ, N'Guessan. Chefferie en mutation en Côte d'Ivoire. In: DÉBATS : Courrier de I'Afrique de I'Ouest. Abidjan : CERAP/ Inades, n. 21, jan. 2005. p. 15-20.

KOUROUMA, Ahmadou. Les soleils des Indépendances. Paris: Seuil, 1970. 198 p. (Points, P166).

Monnè, outrages et défis. Paris: Seuil, 1990. 282 p. (Points, P556). . En attendant le vote des bêtes sauvages. Paris: Seuil, 1998a. 381 p. (Points, P762).

. Le diseur de vérité. Chatenay-Malabry: Accoria, 1998b. 84 p. (Scènes sur scènes).

Ahmadou Kourouma: Entretien [déc. 1998c]. Réalisation: Yavo Serge Stéphane; N'Goran Koffi David; Diandué Bi Kacou Parfait. In: PARFAIT, Diandue Bi Kacou. Histoire et fiction dans la production romanesque d'Ahmadou Kourouma. 2003. Thèse (Doctorat en Sciences de l'Homme et de la Société) - Faculté des Lettres Département de Littérature générale et comparée, Université de Limoges, Limoges. 2003. Não paginado. Disponível em : <http://www.unilim.fr/theses/2003/lettres/2003limo0002/these.html>. Acesso em: 10 jul. 2005.

Ahmadou Kourouma : Entretien [oct. 1999]. Réalisation : Thibault Le Renard ; Comi M. Toulabor. In : Politique Africaine, Paris, n. 75, oct. 
1999. p. 178-183. Disponível em: <http://www.politiqueafricaine.com/numeros/075 SOM.HTM>. Acesso em: 24 fev. 2007.

. Allah n'est pas obligé. Paris: Seuil, 2000. 224 p. (Points, P940).

. Rencontre avec Ahmadou kourouma. Entretien [mars 2003].

Réalisation: François Xavier. Disponível em:

$<$ http://www.francoisxavier.net/article.php3?id article=33 > . Acesso em: 05 jan. 2006.

. Ahmadou Kourouma: Entretien [août 2000]. Réalisation: Vingonin Tinan Nina; Diandué Bi Kacou Parfait. In: PARFAIT, Diandue Bi Kacou. Histoire et fiction dans la production romanesque d'Ahmadou Kourouma. 2003. Thèse (Doctorat en Sciences de l'Homme et de la Société) - Faculté des Lettres - Département de Littérature générale et comparée, Université de Limoges, Limoges. 2003. Não paginado. Disponível em: <http://www.unilim.fr/theses/2003/lettres/2003limo0002/these.html>. Acesso em: 10 jul. 2005.

. Ahmadou Kourouma: Entretien [juin 2002]. Réalisation: Diandué Bi Kacou Parfait. In: PARFAIT, Diandue Bi Kacou. Histoire et fiction dans la production romanesque d'Ahmadou Kourouma. 2003. Thèse (Doctorat en Sciences de l'Homme et de la Société) - Faculté des Lettres - Département de Littérature générale et comparée, Université de Limoges, Limoges. 2003. Não paginado. Disponível em : <http://www.unilim.fr/theses/2003/lettres/2003limo0002/these.html>. Acesso em: 10 jul. 2005.

. Quand on refuse on dit non. Texte établi par Gilles Carpentier. Paris: Seuil, 2004. 160 p.

LAVERGNE, Evelyn. Les indépendances et les métamorphoses du roman africain. In: REVUE DE LITTÉRATURE ET D'ESTHÉTIQUE NÉGROAFRICAINES. Institut de Littérature et d'esthétique Négro-Africaines. Abidjan : NEA, n. 4, 1982. p. 19-23. 
LEZOU, Gérard Dago. La Création romanesque devant les transformations actuelles de la Cote d'Ivoire. Préface: Guy Michaud. Abidjan-Dakar: NEA, 1977. 260 p.

. Les romanciers africains francophones à la recherche d'une personnalité nationale: L'exemple de la Guinée et de la Côte d'Ivoire. 1988. Thèse (Doctorat d'État ès lettres et Sciences Humaines) - Centre de sémiotique textuelle, Université Paris X-Nanterre, Paris. 1988. 547 p.

. Le corps romanesque comme lieu symbolique et métaphorique. In: LEZOU, Gérard Dago et al. Sémiologie du corps romanesque dans Les soleils des Indépendances, d'Ahmadou Kourouma. Abidjan: EDUCI, 2002. p. 61-78.

LEZOU, Gérard Dago et al. Sémiologie du corps romanesque dans Les soleils des Indépendances, d'Ahmadou Kourouma. Abidjan: EDUCI, 2002. $154 \mathrm{p}$.

MAALOUF, Amin. Les identités meurtrières. Paris: Grasset \& Fasquelle, 1998. 189 p.

M'BOKOLO, Elikia. L'ère des indépendances. In: NOTRE LIBRAIRIE : Revue du livre: Afrique, Caraïbes, Océan Indien. Écrivains de langue française : Afrique noire, Maghreb, Caraïbes, Océan Indien. Paris : Clef, n. 108, jan.mars 1992. p. 18-22.

MAGNIER, Bernard. Ahmadou Kourouma. In: NOTRE LIBRAIRIE : Revue du livre Afrique noire, Maghreb, Caraïbes, Océan Indien. Littérature de Côte d'Ivoire II: Écrire aujourd'hui. Paris : Clef, n. 87, p.11-15, avr.-juin 1987. Ahmadou Kourouma. In: NOTRE LIBRAIRIE : Revue du livre: Afrique, Caraïbes, Océan Indien. 1980 - 1990 : Dix ans de Littérature : I. Maghreb - Afrique Noire. Paris : Clef, n. 103, p. 92-96, oct.-déc. 1990a.

. Beurs noirs à Black Babel. In : NOTRE LIBRAIRIE : Revue du livre : Afrique, Caraïbes, Océan Indien. 1980 - 1990 : Dix ans de Littérature : I. Maghreb - Afrique Noire. Paris : Clef, n. 103, p. 102-107, oct.-déc. 1990b. 
MAKOUTA-MBOUKOU, Jean-Pierre. Introduction à l'étude du roman négroafricain de langue française: Problèmes culturels et littéraires. $2^{\mathrm{e}}$ éd. Abidjan: NEA, 1980. 349 p.

. Les origines inavoués du genre romanesque négro-africain. In : Introduction à l'étude du roman négro-africain de langue française: Problèmes culturels et littéraires. $2^{\mathrm{e}}$ éd. Abidjan: NEA, 1980. 349 p.

. Spiritualités et cultures dans la prose romanesque et la poésie négro-africaine: De l'oralité à l'écriture. Préface: Charles Valy Diarrassouba. Abidjan: NEA, 1983. 247 p.

M'LANHORO, Joseph. (org.) Essai sur Les soleils des indépendances. Abidjan: NEA, [1974]. 99 p.

. Géographie du corps humain. In : LEZOU, Gérard Dago et al. Sémiologie du corps romanesque dans Les soleils des Indépendances, d'Ahmadou Kourouma. Abidjan: EDUCI, 2002. p. 1559.

MAQUET, Jacques. Ancêtre. In : BALANDIER, Georges et MAQUET, Jacques (Dir.). Dictionnaire des civilisations africaines. Paris : Fernand Hazan, 1968. p. 18-21.

MATOS, Olgária. Vestígios: escritos de filosofia e crítica social. Apresentação: Humberto Mariotti. São Paulo: Palas Athena, 1998. 164 p.

MEMEL-FOTÊ Harris. La bâtardise. In : M'LANHORO, Joseph. (org.) Essai sur Les soleils des indépendances. Abidjan: NEA, [1974]. p. 53-65.

MIDIOHOUAN, Guy Ossito. L'Idéologie dans la littérature négro-africaine d'expression française. Paris: L'Harmattan, 1986. 249 p. (Littéraire).

MILLOGO, Louis. Nazi Boni - premier écrivain du Burkina Faso: La langue bwamu dans Crépuscule des temps anciens. Limoges: Pulim, 2002. 307 p. (Francophonies).

MONGO-BOUSSA, Boniface. Désir d'Afrique. Préface: Ahmadou Kourouma. Postface : Sami Tchak. Paris: Gallimard, 2002. 336 p. 
MONTEIL, Vincent. Préface. In : HAMIDOU KANE, Cheikh. L'Aventure ambiguë. Préface : Vincent Monteil. Paris: Julliard, 2005. p. 5-10. $(10 / 18,617)$.

MOURALIS, Bernard. Littérature et développement: Essai sur le statut, la fonction, et la représentation de la littérature négro-africaine d'expression française. Paris: Silex, 1984. 719 p.

N'DA K., Pierre. Le conte africain et l'éducation. Paris: L'Harmattan, 1984. $248 \mathrm{p}$.

NGANDU NKASHAMA, Pius. Les années littéraires en Afrique (1912-1987). Paris :L'Harmattan, 1993. $455 \mathrm{p}$.

. Les années littéraires en Afrique (1987-1992). Paris: L'Harmattan, 1994. 125 p.

. Ruptures et écritures de violence : Études sur le roman et les littératures africaines contemporaines. Paris: Harmattan, 1997. 386 p. (Critiques Littéraires).

N'GUESSAN KOTCHY, Barthélémy. Signification de I'oeuvre. In: M'LANHORO, Joseph. (org.) Essai sur Les soleils des indépendances. Abidjan: NEA, [1974]. p. 81-93.

NIANE, Djibril T. Soundjata ou l'épopée du mandingue. Paris: Présence Africaine, 1960. $153 \mathrm{p}$.

NICOLAS, Jean-Claude. Comprendre Les Soleils des indépendances d'Ahmadou Kourouma. Issy les Moulineaux: Saint Paul, 1985. 192 p. (Les classiques africains).

NOKAN, Charles. Le soleil noir point. Préface: Pierre Stibbe. Paris: Présence Africaine, 1962. $70 \mathrm{p}$.

. Violent était le vent. Paris : Présence Africaine, 1966. 178 p.

. Charles Nokan: Depoimento [mar. 2006]. Entrevistadora: Maria Suzana Moreira do Carmo. Abidjan, 2006. 1 fita cassete (60 min). 
ORTIZ, Fernando. Do fenômeno social da "transculturação" e de sua importância em Cuba. Tradução: Lívia Reis. In: Contrapunteo cubano del tabaco y del azúcar.. La Habana: Editorial de Ciencias Sociales, 1983. Disponível em: <http://www.cdrom.ufrgs.br/ortiz/index.htm>. Acesso em: 20/09/07, às 14:50.

OUOLOGUEM, Yambo. Le devoir de violence. Paris : Seuil, 1968. 208 p.

PAULME, Denise. Bambara. In : BALANDIER, Georges et MAQUET, Jacques (Dir.). Dictionnaire des civilisations africaines. Paris : Fernand Hazan, 1968. p. 58-61.

PARFAIT, Diandue $\mathrm{Bi}$ Kacou. Histoire et fiction dans la production romanesque d'Ahmadou Kourouma. 2003. Thèse (Doctorat en Sciences de l'Homme et de la Société) - Faculté des Lettres Département de Littérature générale et comparée, Université de Limoges, Limoges. 2003.2 Disponível em : <http://www.unilim.fr/theses/2003/lettres/2003limo0002/these.html>. Acesso em: 10 jul. 2005. Não paginado.

PERRONE-MOISÉS, Leila. Inútil poesia e outros ensaios breves. São Paulo: Companhia das Letras, 2000. 364 P. - Literatura Comparada, Intertexto e Antropofagia. In: Flores na escrivaninha. São Paulo, Companhia das Letras, 1998. p. 91-99.

PINTO, Maria Cecília de Moraes. Alencar e a França: perfis. São Paulo: Annablume, 1999. 275 p. (Parcours).

RICOEUR, Paul. Tempo e narrativa. Tomo III. Tradução: Roberto Leal Ferreira; revisão técnica: Maria da Penha Villela-Petit. Campinas: Papirus, 1997. 519 p. Título original: Temps et récit - Tome III : Le temps raconté.

RIPAULT, Ghislain. Les soleils de Kourouma brillent par leur présence. In : NOTRE LIBRAIRIE: Revue du livre Afrique noire, Maghreb, Caraïbes, Océan Indien. Littérature de Côte d'Ivoire II: Écrire aujourd'hui. Paris : Clef, n. 87, avr.-juin 1987. p. 6-10. 
RIVAS, Pierre. Claridade. Emergence et différentiation d'une littérature nacionale. L'Exemple du Cap Vert. Quadrant 6. Monpellier, déc. 1986, p. 109-118.

SARTRE, Jean-Paul. Orfeu negro. In: Reflexões sobre o racismo. Tradução: J. Guinsburg. São Paulo: Difel, 1961. 125 p.

. Colonialismo e neocolonialismo (Situações V). Tradução: Diva Vasconcelos. Rio de Janeiro: Tempo Brasileiro, 1968. 205 p.

SENGHOR, Léopold Sédar. Léopold Sédar Senghor par lui-même. Propos recueillis par Édouard J. MAUNICK. In : NOTRE LIBRAIRIE : Revue des littératures du Sud. 1250 nouveaux titres de littérature d'Afrique noire 1997-2001. Paris : Clef, n. 147, jan.-mars 2002. 186 p.

SIDIBÉ, Charles-Adolphe. La fiction intime dans Les soleils des Indépendances d'Ahmadou Kourouma. In : Revue GELL. Sénégal : Université Gaston Berger de Saint-Louis, n. 9, jan. 2005.

SOUZA, Eneida Maria de. Sujeito e identidade cultural. In: REVISTA BRASILEIRA DE LITERATURA COMPARADA. Niterói: Abralic, n. 1, mar. 1991. p. 34-40.

TAP, Pierre (Dir.). Identités collectives et changements sociaux: production et affirmation de l'identité. Toulouse : Privat, 1980. $456 \mathrm{p}$.

TAYLOR, Charles. El multiculturalismo y "la política del reconocimiento". Comentarios de Amy Gutmann, Steven C. Rockefeller, Michael Walzer y Susan Wolf. México: Fondo de Cultura Económica, 2001. 159 p.

TIDJANI SERPOS, Nouréini. Aspects de la critique africaine. Tome I. Paris: Silex; Lomé-Togo: HAHO, 1987. 288 p.

TODOROV, Tzvetan. Nous et les autres: La réflexion française sur la diversité hunaine. Paris: Seuil, 1989. 458 p.

TRAORÉ, Aminata. Les femmes ivoiriennes dans la parole. In : NOTRE LIBRAIRIE : Revue du livre Afrique noire, Maghreb, Caraïbes, Océan Indien. Littérature de Côte d'Ivoire I: La Mémoire et les mots. Paris : Clef, n. 86, pp. 106-111, jan.-mars 1987. 
WONDJI, Christophe. "Le contexte historique". In: M'LANHORO, Joseph. (org.) Essai sur Les soleils des indépendances. Abidjan: NEA, [1974]. p. 1726.

ZADI ZAOUROU, Bernard. La parole poétique dans la poésie africaine: domaine de l'Afrique de l'ouest francophone. 1981. Thèse (Doctorat d'État) - Lettres et Sciences Humaines - Université de Strasbourg II, Strasbourg. 1981.

. Bernard Zadi Zaourou: Depoimento [mar. 2006]. Entrevistadora: Maria Suzana Moreira do Carmo. Abidjan, 2006. 2 fitas cassete (120 min). ZATONYI, Marta. (Texto y compilación). Aportes a la estética: desde el arte y la ciencia. Buenos Aires: Biblioteca de la mirada, 1998. 282 p.

\section{Periódicos consultados:}

DÉBATS : Courrier de I'Afrique de l'Ouest. Abidjan : CERAP/ Inades, n. 21, jan. 2005. 32 p.

DÉBATS : Courrier de l'Afrique de l'Ouest. Abidjan : CERAP/ Inades, n. 22, fév. 2005. 32 p.

DÉBATS : Courrier de l'Afrique de l'Ouest. Abidjan : CERAP/ Inades, n. 32, fév. 2006. $32 \mathrm{p}$.

LE MONDE DIPLOMATIQUE : Manière de voir 79. Résistences africaines. Paris, [s.n.], n. 79, fév.-mars 2005. 98 p.

REVISTA BRASILEIRA DE LITERATURA COMPARADA. Niterói: Abralic, n. 1, mar. 1991. $166 \mathrm{p}$.

REVUE DE LITTÉRATURE ET D'ESTHÉTIQUE NÉGRO-AFRICAINES. Institut de Littérature et d'esthétique Négro-Africaines. Abidjan: NEA, n. 1, 1977. $193 \mathrm{p}$.

REVUE DE LITTÉRATURE ET D'ESTHÉTIQUE NÉGRO-AFRICAINES. Institut de Littérature et d'esthétique Négro-Africaines. Abidjan: NEA, n. 2, 1979. $146 \mathrm{p}$. 
REVUE DE LITTÉRATURE ET D'ESTHÉTIQUE NÉGRO-AFRICAINES. Institut de Littérature et d'esthétique Négro-Africaines. Abidjan: NEA, n. 4, 1982. $109 \mathrm{p}$.

REVUE DE LITTÉRATURE ET D'ESTHÉTIQUE NÉGRO-AFRICAINES. Institut de Littérature et d'esthétique Négro-Africaines. Abidjan: NEA, n. 5, 1984. $110 \mathrm{p}$.

REVUE DE LITTÉRATURE ET D'ESTHÉTIQUE NÉGRO-AFRICAINES. Institut de Littérature et d'esthétique Négro-Africaines. Abidjan: NEA, n. 6, 1985. $107 \mathrm{p}$.

REVUE DE LITTÉRATURE ET D'ESTHÉTIQUE NÉGRO-AFRICAINES. Institut de Littérature et d'esthétique Négro-Africaines. Abidjan : NEA, n. 8, 1987. $110 \mathrm{p}$.

REVUE GELL. Sénégal : Université Gaston Berger de Saint-Louis, n. 9, jan. 2005.

NOTRE LIBRAIRIE : Revue du livre Afrique noire, Maghreb, Caraïbes, Océan Indien. Littérature de Côte d'Ivoire I: La Mémoire et les mots. Paris : Clef, n. 86, jan.-mars 1987. 149 p.

NOTRE LIBRAIRIE : Revue du livre Afrique noire, Maghreb, Caraïbes, Océan Indien. Littérature de Côte d'Ivoire II: Écrire aujourd'hui. Paris : Clef, n. 87, avr.-juin 1987. 165 p.

NOTRE LIBRAIRIE : Revue du livre : Afrique, Caraïbes, Océan Indien. 1980 1990 : Dix ans de Littérature : I. Maghreb - Afrique Noire. Paris : Clef, n. 103, oct.-déc. 1990. 150 p.

NOTRE LIBRAIRIE : Revue du livre : Afrique, Caraïbes, Océan Indien. Écrivains de langue française: Afrique noire, Maghreb, Caraïbes, Océan Indien. Paris : Clef, n. 108, jan.-mars 1992. 207 p.

NOTRE LIBRAIRIE : Revue des littératures du Sud. Nouveaux paysages littéraires: Afrique, Caraïbes, Océan Indien 1996-1998/2. Paris : Clef, n. 136, jan.-avr. 1999. 173 p. 
NOTRE LIBRAIRIE : Revue des littératures du Sud. 1250 nouveaux titres de littérature d'Afrique noire 1997-2001. Paris : Clef, n. 147, jan.-mars 2002. $186 \mathrm{p}$.

NOTRE LIBRAIRIE : Revue des littératures du Sud. 40 ans de littératures du Sud. Paris : Clef, n. 150, avr.-juin 2003. 159 p. 


\section{ANEXOS}

\section{Anexo 1 :}

Charles Nokan, escritor marfinense, autor de várias obras dentre as quais destacam-se Le soleil point (1962), Les malheurs de Tchako (1968), La traversée de la nuit dense (1972).

Interesse : testemunho sobre a identidade cultural africana.

Trecho da entrevista concedida a Maria Suzana Moreira do Carmo, em 18 de em março de 2006293, em Abidjan, Costa do Marfim:

La plupart de ceux qui écrivent sont allés à l'école du colonisateur et donc ils sont en partie influencé par l'éducation qu'ils ont reçu au niveau de l'école. Il y avait une forme d'école dans nos régions, dans nos différents groupes ethniques, mais c'était une école auprès des parents [car] c'était une époque d'expériences, c'était par rapport à ce que faisaient les parents, par rapport à ce qu'ils vous disaient ; tout était oral à ce moment-là ; avant d'être éduqués au niveau de l'éducation créée par les occidentaux, créée par les colonisateurs, nous avions été formés en partie par cette forme d'éducation que j'appelerais éducation africaine, éducation de l'éthnie auprès des parents qui ne se fait que par l'expérience. Maintenant, nous avons eu (sic) à l'école la culture que nous a présentée l'occident: la France ou l'Angleterre, ça dépend de quelle région d'Afrique. Et il est certain aussi que nous avons acquis une certaine expérience et cela transforme l'individu en partie, on a un peu des deux. Donc cela peut apparaître dans ce que nous faisons, que ce soit un tableau, que ce soit une sculpture; la sculpture ancienne était à base de masques, on faisait des masques, on faisait des personnages et maintenant vous voyez qu'il y a beaucoup d'Africains qui font la peinture, qui sont devenus des peintres : soit des peintres réalistes, soit des peintres abstraits. Donc, nous disons que les

293 Por problemas com a gravação, a entrevista não pôde ser integralmente transcrita. 
deux apparaissent dans l'oeuvre; il s'agit maintenant aux lecteurs, aux critiques de voir ce qui est davantage influencé par l'occident et ce qui est en partie [influencé] par nos cultures africaines. 


\section{Anexo 2:}

Bernard Zadi Zaourou, escritor, compositor e diretor de teatro. Foi professor da Universidade de Cocody, em Abidjan e Ministro da Cultura da Costa do Marfim, de 1993 a 2000.

Interesse : testemunho sobre a identidade cultural africana.

Depoimento concedido a Maria Suzana Moreira do Carmo, em 23 de março de 2006, em Abidjan, Costa do Marfim:

Nous allons commencer par parler de la mort et de certains rituels qui s'y rattachent. D'abord, il faut préciser que ce que nous allons dire est totalement indépendant des conceptions chrétiennes, musulmanes, bhoudistes ou autres. La mort, c'est vrai qu'elle a été fortement influencée par le christianisme, très influencée par l'Islam mais la concession de la mort et le sens de la mort sur ce qui devient l'homme après sa mort, ce sont des choses que disent le Koran, la Bible, nous n'en parlerons pas, ce n'est pas notre soucis, je crois. Pour moi, ce n'est pas non plus la conception islamique qui est posée dans ce livre. La mort, en règle générale chez les peuples de l'Afrique noire, la mort est regardée comme un désastre, comme un fléau, contrairement à d'autres cultures où la mort apparaît comme la porte vers un monde plus heureux quand on a mené une vie de $[\ldots]^{294}$ comme chez les musulmans, comme chez les chrétiens, la mort apparaît simplement comme le [...] d'une bonne âme ... la félicité : une espèce de communion avec sa divinité. Dans la spiritualité africaine, celle de l'Afrique noire la notion de paradis n'existe pas, il n'y a pas un univers où les bien heureuses âmes se retrouvent. La notion d'âme, d'ailleurs, en tant que thème n'existe pas, ce qui existe c'est l'ombre, la notion d'ombre qui existe. Alors, l'Africain ne croit pas en paradis mais pour eux, ce qui existe, c'est le pays des ancêtres. Il y a de vastes cités, sous la terre, dans les terres qui sont tout à fait à l'image de nos

${ }^{294}$ Alguns trechos tornaram-se incompreensíveis em razão de ruídos externos. 
villages, de nos villes et, lorsque l'homme meurt, il y a des passages qui changent selon les cultures et les sous-cultures, les passages qu'on franchit et qui nous conduisent dans ces cités-là.

Si j'étais le roi ici je serais le roi là-bas, si j'étais ici esclave je serais esclave làbas également. Si bien que cette concession explique chez certains de nos peuples, il faut le dire, certains rites qui étaient quand même extrêmement pénibles, a savoir par exemple chez les Akan. Les Akan c'est un vaste peuple qui couvre a la fois le Ghana et la Côte d'Ivoire, on dit les Akan mais il y a plusieurs ramifications: les Ashanti, les Baoulés, les Agnis, les Zimah, les Apoloniens et autres. On les appelle globalement les Akan. Cette conception là par exemple, et même ailleurs... il y a certaines contrées de l'ancien Bénin où lorsqu'un roi mourait on l'enterrait avec son épouse préférée et avec ses anciens esclaves. L'ancien Bénin c'est le grand Bénin qui comprend tout le Nigéria actuel, c'est le tout groupe, c'est le Dahomée, le tout c'est le grand Bénin. Donc, ça c'était très répandu, à savoir que quand le roi s'en va, on laisse passer du temps pour qu'on trouve le moins de [...] qui sont indispensables : il faut des porteurs pour porter ses bagages, il faut quand il $y$ arrive qu'il soit installé, qu'il ait ses serviteurs, même si ce n'est pas toutes ses épouses, il faut qu'au moins ses favorites soient autour de lui. Donc, il y a une sorte de conception qui constitue une sorte de monde paralelle souterain à partir de l'image de notre monde réel et les morts, comme on cite souvent un joli petit poème de Birago Diop, "les morts ne sont pas morts », oui, c'est vrai. Chez les Africains, les morts ne sont pas morts: ils survivent sous forme d'énergie. Et l'Africain, l'Afrique noire croit en la réincarnation; les ancêtres du souterrain pays ne vivent plus la vie que nous vivons, ce sont des êtres imatériels et des esprits, mais ils subexistent, ils continuent d'exister sous une forme d'énergie inépuisable; selon les prières, les soins que nous prenons d'eux, le fait de leur apporter de la nourriture régulièrement sur les tombes selon les rites de communion avec eux, eh bien, ils peuvent donner la grâce aux vivants ou alors leur infliger des punitions. A vrai dire, du souterrain pays 
ils continuent de nous gouverner, parce qu'à vrai dire, quelqu'un qui n'est pas puissant, qui est humble ou très modeste dans la vie réelle, une fois qu'il accède au stade d'ancêtre, il devient puissant, il devient plus puissant que n'importe quel roi, même s'il a été esclave. Tous les ancêtres en général, à partir du moment où ils sont des esprits, nous n'avons aucune parade contre eux ; leur colère peut [...] un roi le plus puissant qu'il soit. Quand il y a [...] dans l'hiérarchie, l'être vivant que nous sommes vient loin dans la hiérarchie, dans la hiérarchie à Dieu. L'Africain croit en un Dieu unique depuis toujours. Les uns se trompent quand ils croient que les Africains sont polythéistes, c'est faux. L'Africain croit en un Dieu unique depuis toujours. [...] L'idée que les Africains sont polythéistes vient de la nuit des temps, l'idée même de l'existence de plusieurs dieux n'a jamais habité l'Africain, c'est faux. C'est l'ethnologie qui a raconté des histoires, c'est pas vrai du tout. Quand on fouille, on voit bien que [...], et les Mossis aussi étaient monothéistes. Le fameux [...] on l'appelait le prêtre du Dieu vivant, il était monothéiste, donc au plus loin les Africains n'ont jamais cru à plusieurs dieux, aucune ethnie africaine n'a cru en plusieurs dieux. Dans la hiérarchie, il y a Dieu, qui porte des noms multiples selon les ethnies. Les Guwê l'appellent Gnonsoa en Wê (Guéré et Wobé) gnonsoa, les Akan l'appellent Nyamien, les Bété l'appellent Gueudi zeu zeura, ça veut dire «la rouge Vérité »: gueudi vient de gueudier qui signifie le Vrai, à grand « $V$ », la vérité à grand « $V$ »; zeu zeura, rouge, «la rouge Vérité ».

Donc, il y a Dieu au départ, et après le Dieu, il y a les génies. Les génies ce sont des êtres immatériels qui peuvent habiter un arbre, qui peuvent habiter une source d'eau, qui peuvent habiter également un rocher. Ce sont des êtres immatériels, ce sont des esprits. Ils sont très nombreux et ils ont également leur hiérarchie. Après les génies vient les ancêtres, tous ceux qui sont passés par la vie normale et qui étant morts sont devenus des puissances dans l'autre monde; là-bas aussi ils ont une hiérarchie puisque le roi reste roi là-bas. Mais par rapport aux vivants les ancêtres sont toujours plus puissants; après les ancêtres vient les vieux, les anciens (mais là ce sont les vivants déjà) : oui, ce sont les vivants, dans la vie globale puisqu'il y a une continuité. Viennent donc 
les hommes, les jeunes, les hommes ordinaires, les femmes et les enfants. [...] Alors, il est bien évident que dans la mesure où les morts continuent d'exister sous forme d'énergie, il y a des rites par lesquels on cherche à puiser cette énergie-là. C'est le sens des prières, c'est le sens des grands rituels; une fois aux rites [...] vous allez à cette [...] sacrée où vous dites vos voeux, vous priez, la population chante, on appelle les ancêtres et puis, avant de partir, toute [...] que vous coupez, toute poussée que vous ramassez, tout ce qui est dans ce lieu est comme porteur de cette énergie et sera utile [...] si c'est pour un fruit comestible, vous le mangez ; c'est ce qui va apporter la fécondité, éloigner les mauvais esprits, c'est protecteur. Donc, vous voyez, il y a une connection très étroite entre l'univers des morts et l'univers des vivants. Il n'y a pas de rupture. Donc à cela il faut ajouter le fait que justement à cause de cette conception là, il y a des réalités qui ne sont pas de choses qui ont un statut d'homme; par exemple, certains animaux sont montés, chevauchés, par les esprits : ils ont un statut humain. C'est le cas des fauves en général, c'est le cas d'un animal comme l'éléphant, et il y a plusieurs animaux comme ça ; un arbre peut être un arbre génie. Donc, finalement cette situation fait que... cette conception est enfin un très très grand respect de l'écologie dans la mesure où la terre elle-même a un statut humain, elle est femme, ici elle est mâle parce Dieu ne se mêle pas des affaires des hommes. C'est un Dieu lointain. Ce sont les hiérarchies qui gouvernent l'homme, les vivants, et c'est vraiment quand ça ne va pas du tout que I'homme s'adresse à Dieu directement. Il y a un texte qui est vraiment la preuve que c'est quand I'homme a tout essayé qu'il s'adresse à Dieu directement. C'est pour ça qu'il n'y a pas d'autel pour prier Dieu en Afrique noire ; il n'y a pas un autel comme chez les chrétiens; chacun a un autel domestique comme un peu dans la Grèce antique tel que Fustel de Coulanges en a parlé. Il a créé un livre qui s'appelle la Cité Antique dans lequel il montre les autels domestiques, les autels privés des familles. Il montrait comment ces autels sont des autels domestiques, par famille. Effectivement, chaque famille a... on dit souvent le terme fétiche, nous aprenons le terme fétiche, mais disons a son autel, le mot 
fétiche est un peu plus relatif, mais chaque famille a son autel et puis c'est dans cet autel-là qu'il y a tel génie qu'on adore, mais c'est un intermédiaire avec Dieu. Beaucoup des gens se sont trompé en croyant que l'Africain croit en plusieurs dieux, c'est faux. Aucun Africain, même de huit ans ne peut penser que [...] Quand un Africain veut jurer, un Africain de l'Afrique noire veut jurer, ils disent «Dieu Tout-Puissant et la Terre vaste », il touche du doigt la terre, mais le doigt, l'index, sous sa langue. Dans ma langue, d'habitude on dit nagotopè : Dieu Tout-Puissant et dodo kpata : la vaste Terre et il touche du doigt. Donc la Terre est femme et seulement dans Dieu d'eau, de Marcel Griaule, il existe cette relation entre le ciel qui est mâle et la terre qui est femme. Cette relation, elle s'opère sous le regard de Dieu. Le ciel n'est pas vide, le ciel est plein de dieux. Les Dogon disent Amadieux et c'est Amadieux qui s'est accouplé avec la Terre pour donner naissance à un certain nombre de choses. Marcel Graule, Dieu d'eau. C'est un ouvrage très important pour la condition de l'Afrique.

Evidemment c'est un peu en rapport avec toute cette situation-là que la notion d'ombre prend tout son sens. L'ombre, ce n'est pas exactement l'âme, c'est l'âme sans l'être vraiment, ce n'est pas tout à fait l'âme comme les chrétiens l'entendent. L'ombre, c'est la force vitale de l'homme. (il y a une différence entre l'ombre et le dja?) C'est un peu compliqué : même les chrétiens distinguent l'homme et l'esprit. Chez nous, chez les Africains en général... c'est pour ça que j'ai du mal à expliquer. [...] lorsque que quelqu'un meurt et qu'il est enterré, au moment où on va l'enterrer, l'ombre est censée survoler audessus de ce corps jusqu'à l'enfouissement. Puis, selon les régions, selon les cultures, il y a un lieu par où passe les morts pour rejoindre le souterain pays des morts. Et ce lieu-là, c'est l'ombre qui le gagne ce lieu-là. L'ombre est un un peu regardée comme le bulbe de l'être, le bulbe immatériel de l'être, mais en même temps c'est différent de la force vitale que les Bété appellent uga. Uga c'est... par exemple, lorsque qu'il y a un accident d'avion, tout le monde meurt et puis une seule personne échappe à cet acident, on dira son uga est fort; mais ce n'est pas son ombre; en français c'est difficile parce que ce sont des 
concepts tellement différents, mais son principe de vie est puissant. L'ombre s'approcherait davantage de l'âme. Chez les malinkés c'est probable, dans les autres cultures je ne peux pas l'affirmer parce que la mort apparaît sous la forme allégorique, comme un personnage, elle est regardée comme un esprit qui chez certains peuples de chez nous... il y a une armée [...] qui marche avec le personnage de la mort. Et dès notre naissance et même déjà dans le sein de notre mère cette force là est dejà presente à nous, c'est elle qui mettra fin à la vie. Donc, dans le sens populaire, dans ma région on appelle la mort téti gazowa. Téti gazowa c'est la mort, il monte à la tête de ses armées et frappe qui il veut, quand il veut, c'est lui qui met fin à la vie, mais c'est un personnage, un personnage connu et quand quelqu'un, par exemple chez un poète comme Amédée Pierre, il dit que lorsque I'homme descend aux frontières de l'au-delà ; à cette frontière, il y a une personnage qui s'appelle Ghédé ou Ghédé du souterain pays. Ce Ghédé on le trouve chez les Haïtiens. Si vous mangez de sa nourriture, vous ne revenez plus. Vous passez de l'autre côté, puis c'est fini. C'est comme cette frontière où il y a le Cerbère chez les occidentaux, chez les Grecs. Cerbère est à la porte et il y a un personnage qui vous fait la traversée, mais ici, Ghédé du souterrain pays il est aux frontières entre le souterrain pays et le pays des vivants et quand vou arrivez, il vous accueille, il vous fait asseoir et il vous propose à manger. Si vous mangez, vous ne pouvez plus revenir; si vous ne mangez pas, à ce moment-là, il y a des gens qui vous réveillent, celui qui est dans le coma qui se réveille c'est qu'il n'a pas mangé. Donc, finalement, il y a peut être une trinité chez les Malinkés, mais ailleurs, entre l'ombre, le uga, qui sont des principes de vie, et téti qui est le principe de mort chez certains peuples; la mort dans tous les cas est un personnage guerrier, c'est peut-être dans ce trépied-là que le mystère de la vie se déploie, à l'intérieur de cet espace triadique qui se déroule le mystère de la vie. La mort est vraiment un personnage, c'est un guerrier qui a eu toute une armée derrière et il est tout le temps en offensive : on a beau le supplier, il est tout le temps en guerre contre l'homme et comme les Africains n'ont pas Satan dans leur mythologie, la mort est peut-être le diable 
en personne, fait pour torturer les hommes, pour les faire souffrir et tuer quand il veut et comme il veut, pour ne faire que du mal. Donc, dans ce cas-là, le mystère de la vie se déroule entre l'ombre, la force vitale qui est le uga et puis le poids de la mort ; c'est déjà un espace triadique là. Mais on ne peut pas I'affirmer puisqu'en fait des études n'ont pas été faites systhématiquement sur cette question; on sait que ces données-là sont réelles, qui elles font partie de nos croyances mais il n'y a pas de recherche systhématique. 


\section{Anexo 3:}

Área atualmente ocupada pelos Malinkés (mapa modificado de R. Mauny). ${ }^{295}$

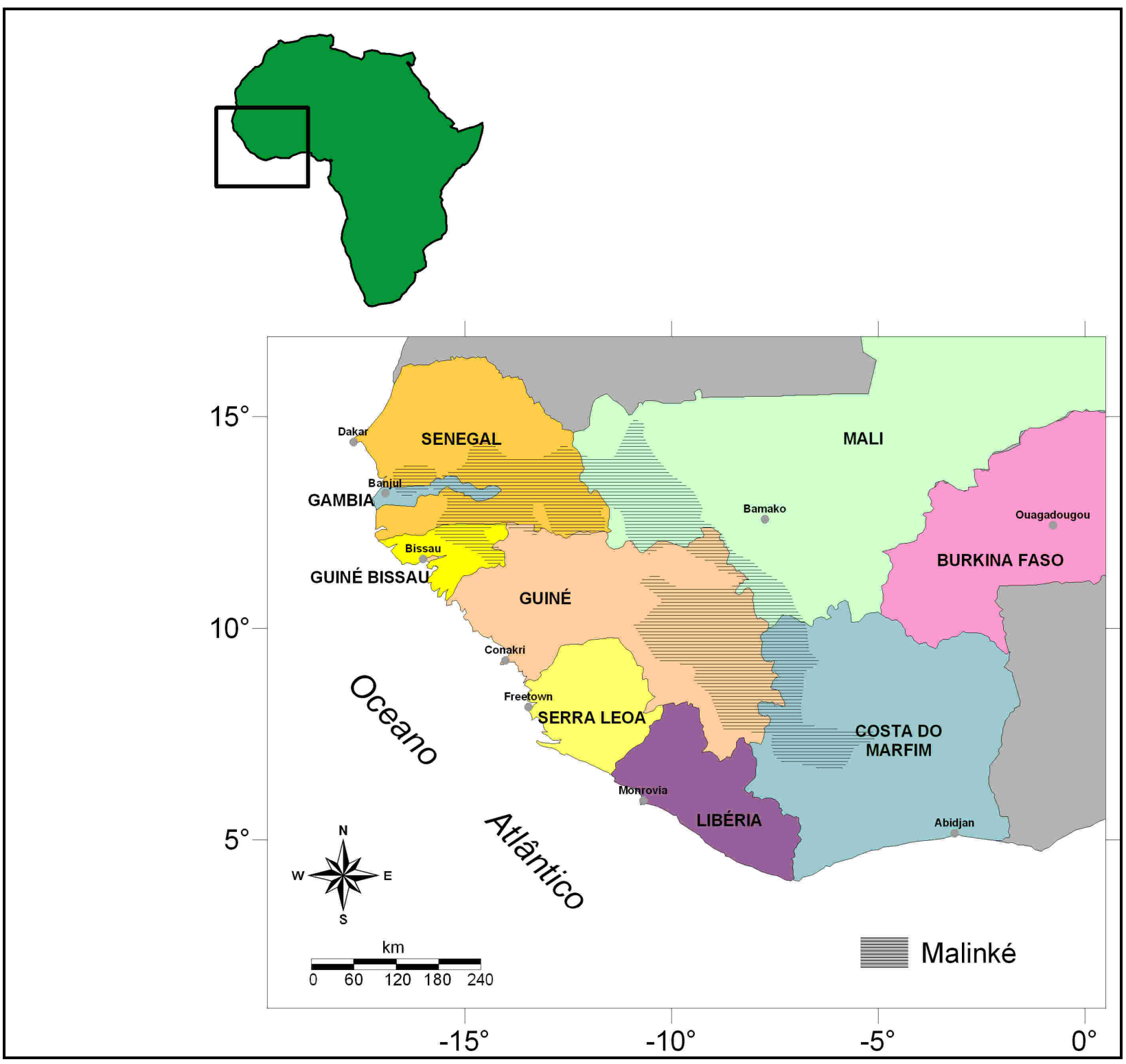

${ }^{295}$ In: CAMARA, 1992, op. cit., p. 22. 